\title{
DESEMPENHO DE LAGOAS DE MATURAÇÃO UTILIZANDO MACRÓFITAS AQUÁTICAS E CHICANEAMENTO
}

\section{Kleber Castilho Polisel}

Tese apresentada à Escola de Engenharia de São Carlos, da Universidade de São Paulo, como parte dos requisitos para obtenção do título de Doutor em Engenharia Civil: Área de Concentração Hidráulica e Saneamento.

Orientador: Prof. Tit. Eduardo Cleto Pires 
À minha esposa. 


\section{AGRADECIMENTOS}

Ao professor Eduardo Cleto Pires, pela sua orientação, apoio e incentivo dados para a realização desse trabalho.

À Companhia de Saneamento Básico do Estado de São Paulo (SABESP), da qual eu sou empregado, pelo apoio na realização desse trabalho.

Ao Eng ${ }^{o}$ Luis Paulo de Almeida Neto, gerente do Departamento de Desenvolvimento Operacional da SABESP em Lins, pelo constante incentivo e pelo exemplo de profissionalismo.

Aos amigos da SABESP de Novo Horizonte pelo auxílio na condução do experimento.

À minha mãe Helena e aos meus irmãos Patrícia e Eduardo pelo carinho e motivação.

Às minhas filhas Júlia e Beatriz pelo amor e carinho.

À minha esposa Tânia, por sua compreensão, carinho amizade e amor. 


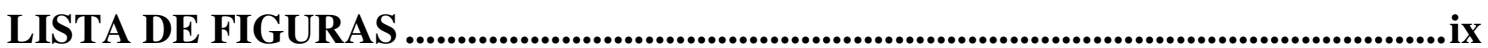

LISTA DE TABELAS ..................................................................................................

LISTA DE ABREVIATURAS, SIGLAS E SÍMBOLOS ........................................xv

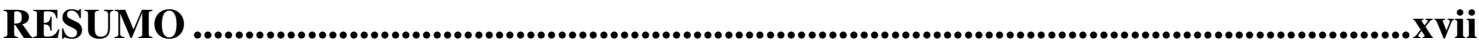

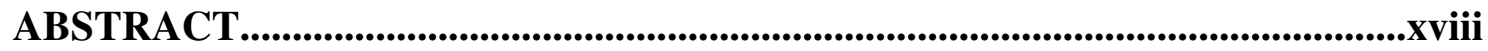

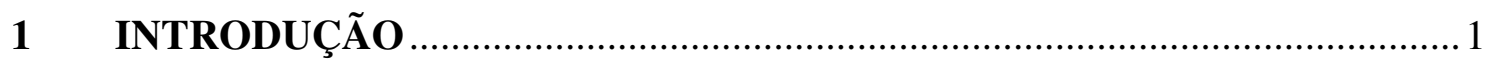

2 OBJETIVOS

3 PROCEDIMENTOS EXPERIMENTAIS …...........................................

3.1 Caracterização do local de pesquisa.....................................................................

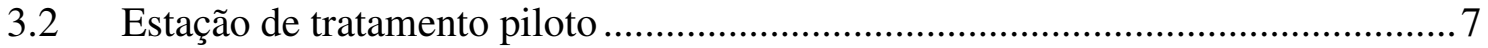

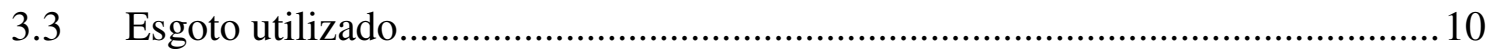

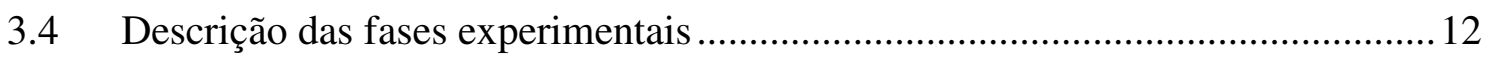

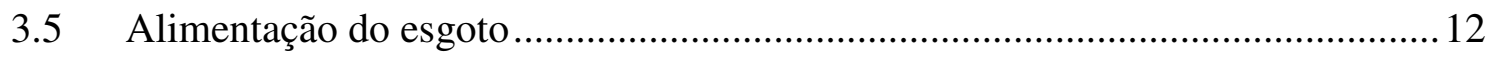

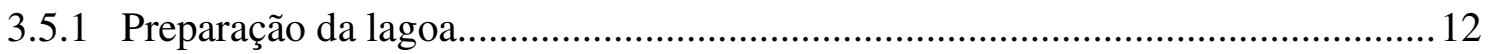

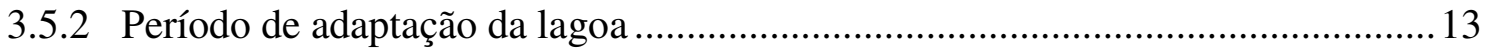

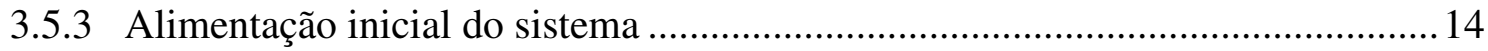

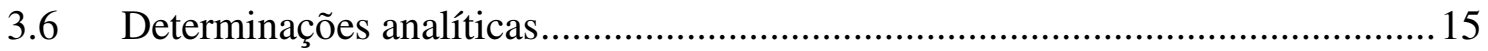




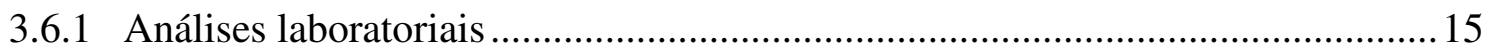

3.6.2 Análises e determinações locais e de campo......................................................17

4 APLICAÇÃO DE MACRÓFITAS AQUÁTICAS..............................................18

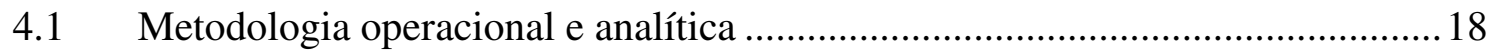

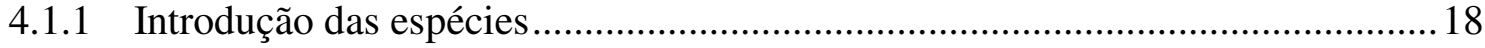

4.1.2 Tempo de detenção hidráulico ……………………………………………..... 18

4.1.3 Rotinas operacionais ................................................................................... 19

4.1.4 Manejo das plantas................................................................................. 19

4.1.5 Determinação da presença de mosquitos ..........................................................20

4.1.6 Sistema convencional comparativo...................................................................21

4.2 Aplicação do aguapé (Eichhornia Crassipes)...................................................21

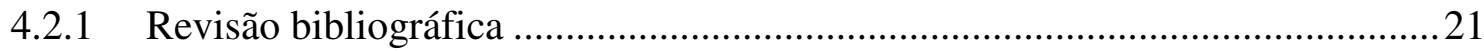

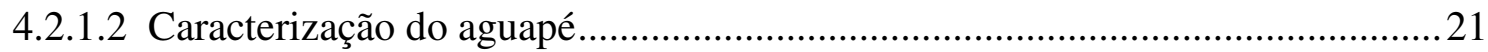

4.2.1.3 Composição química e utilização do aguapé …………………………………...22

4.2.1.4 Capacidade de depuração ............................................................................23

4.2.1.5 Produtividade do aguapé .................................................................................2 23

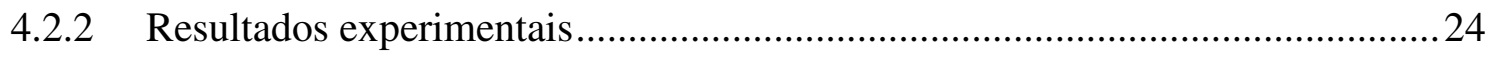

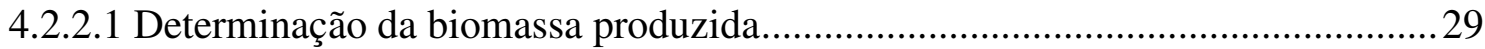

4.2.2.2 Taxa de aplicação superficial e carregamento orgânico para aplicação de

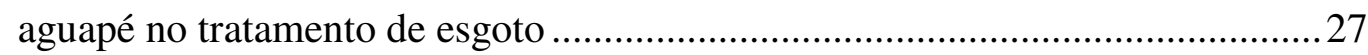

4.2.2.3 Aceitabilidade do aguapé por animais .......................................................2

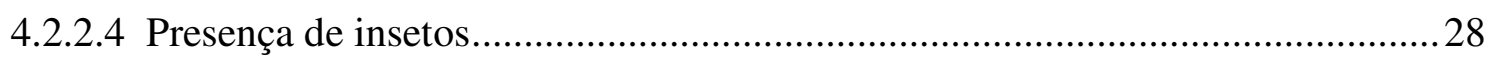

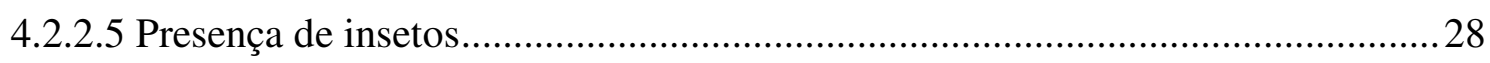

4.3 Aplicação da lentilha d'água (Lemna minor)....................................................... 36

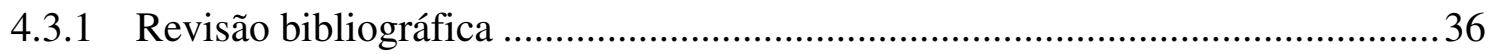

4.3.1.1 Caracterização da lentilha d'água ......................................................................... 36

4.3.1.2 Utilização da lentilha d'água em sistemas naturais de tratamento.........................37

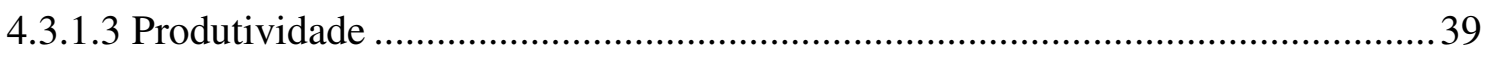

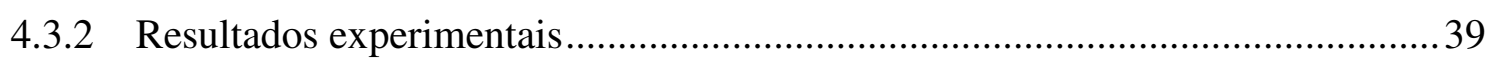

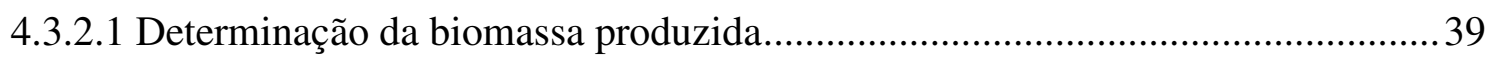

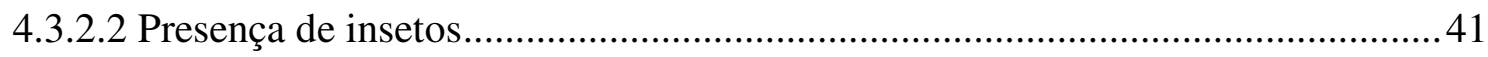

4.3.2.3 Análises físico-químicas ................................................................................. 42 
5 ESTRATIFICAÇÃO TÉRMICA EM LAGOAS DE ESTABILIZAÇÃO ...50

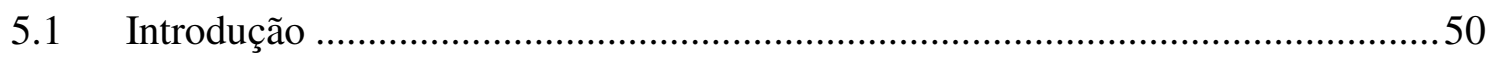

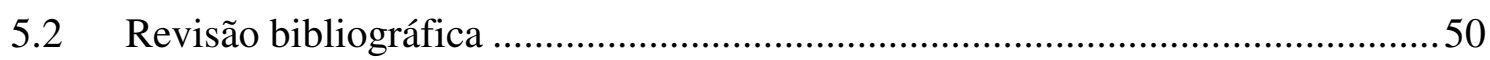

5.2.1 Comportamento hidráulico de lagoas de estabilização .......................................50

5.1.2 O fenômeno da estratificação térmica............................................................56

5.1.3 Características hidráulicas e influência da estratificação térmica no processo de depuração em lagoas de estabilização...........................................................58

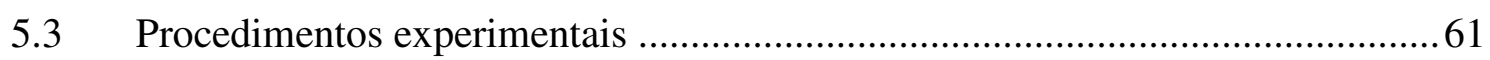

5.3.1 Método para determinação do escoamento interno de lagoa de estabilização....62

5.3.2 Medidas do tempo de detenção hidráulico real .................................................66

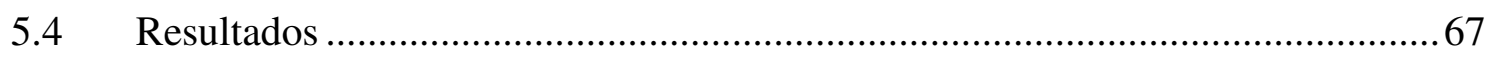

5.4.1 Lagoa sem chicaneamento (controle)...........................................................67

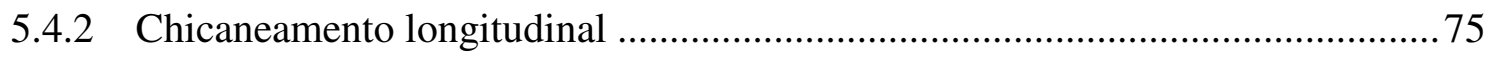

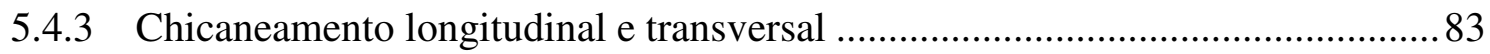

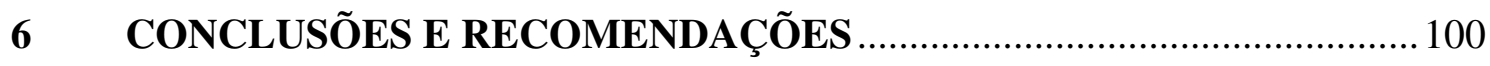

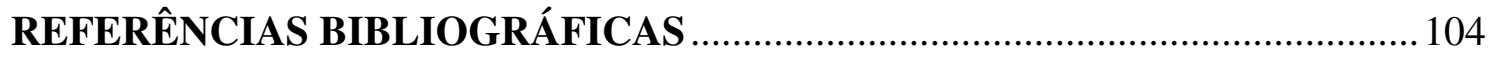

APÊNDICE A - Resultados de análises físico-químicas e bacteriológicas do esgoto afluente à lagoa com aguapé ................................................ 111

APÊNDICE B - Resultados de análises físico-químicas e bacteriológicas do esgoto efluente da lagoa de maturação ...................................................... 113

APÊNDICE C - Resultados de análises físico-químicas e bacteriológicas do esgoto efluente da lagoa com aguapé.

APÊNDICE D - Resultados de análises físico-químicas e bacteriológicas do esgoto afluente à lagoa com lentilha d'água..

APÊNDICE E - Resultados de análises físico-químicas e bacteriológicas do esgoto afluente à lagoa de maturação.

APÊNDICE F-Resultados de análises físico-químicas e bacteriológicas do esgoto efluente da lagoa com lentilha d'água.................................. 121

APÊNDICE G - Medidas de temperatura obtidas na lagoa sem chicaneamento ao longo do período de análise 
hidrodinâmica. Medidas às 16 horas de cada dia. Valores obtidos nos pontos 1, 2, 3 conforme FIGURA 6.19. 123

APÊNDICE H - Valores de OD na lagoa sem chicaneamento ao longo do período de análise hidrodinâmica. Medidas às 16 horas da tarde de cada dia. Valores obtidos no ponto 2 conforme FIGURA 5.5 125

APÊNDICE I - Valores de DQO na lagoa sem chicaneamento ao longo do período de Análise hidrodinâmica. Medidas às 16 horas de cada dia. Valores obtidos no ponto 2 conforme FIGURA 5.5.........127

APÊNDICE J - Concentração de Rodamina obtida na lagoa sem chicaneamento ao longo do período de análise hidrodinâmica. Medidas às 16 horas de cada dia. Valores obtidos no ponto 2 conforme FIGURA 5.5.....129

APÊNDICE K - Medidas de temperatura obtidas na lagoa com chicaneamento longitudinal ao longo do período de análise hidrodinâmica. Medidas às 16 horas de cada dia. Valores médios nos pontos 1,2 e 3 conforme FIGURA 5.12.

APÊNDICE L - Valores de OD na lagoa com chicaneamento longitudinal ao longo do período de análise hidrodinâmica. Medidas às 16 horas de cada dia. Valores obtidos no ponto 2 conforme FIGURA 5.12 133

APÊNDICE M - Valores de DQO na lagoa com chicaneamento longitudinal ao longo do período de análise hidrodinâmica. Medidas às 16 horas de cada dia. Valores obtidos no ponto conforme FIGURA 5.12 135

APÊNDICE N - Concentração de Rodamina obtida na lagoa com chicaneamento longitudinal ao longo do período de análise hidrodinâmica. Medidas às 16 horas de cada dia . Valores obtidos nos pontos 1,2 e 3 conforme FIGURA 5.12 .................................. 137

APÊNDICE O - Medidas de temperatura obtidas na lagoa com chicaneamento longitudinal e transversal ao longo do período de análise hidrodinâmica. Medidas às 16 horas de cada dia. Valores médios dos pontos 1,2 e 3 conforme FIGURA 5.19. 139 
APÊNDICE P - Valores de OD na lagoa com chicaneamento longitudinal e transversal ao longo do período de análise hidrodinâmica. Medidas às 16 horas de cada dia. Valores obtidos no ponto 2 conforme FIGURA 5.12

APÊNDICE Q - Valores de DQO na lagoa com chicaneamento longitudinal e Transversal ao longo do período de análise hidrodinâmica. Medidas às 16 horas de cada dia . Valores obtidos no ponto 2 conforme FIGURA 5.19......................... 143

APÊNDICE R - Concentração de Rodamina obtida na lagoa com chicaneamento longitudinal e transversal ao longo do período de análise hidrodinâmica. Medidas às 16 horas de cada dia. Valores obtidos nos pontos 1,2 e 3 conforme FIGURA 5.19 145

APÊNDICE S - Realização dos ensaios de fluorescência 147 
FIGURA 3.1 - Detalhes construtivos da lagoa experimental........................................ 8

FIGURA 3.2 - Lagoa experimental em construção …..................................................... 8

FIGURA 3.3 - Croqui das lagoas de estabilização de Novo Horizonte e posicionamento

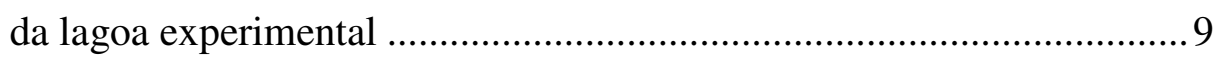

FIGURA 3.4 - Vista da lagoa com aguapé e lagoa de maturação................................... 10

FIGURA 3.5 - Vista aérea da Estação de Tratamento de Esgoto - Novo Horizonte, SP11

FIGURA 3.6 - Método de limpeza da lagoa ao final de cada experimento ..................... 13

FIGURA 4.1 - Fotografia do aguapé - detalhe da flor ................................................22

FIGURA 4.2 - Detalhe da setorização do canal para manejo do aguapé .........................25

FIGURA 4.3 - Aguapé em fase produtiva ….............................................................2 27

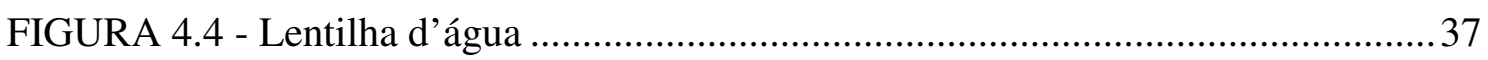

FIGURA 4.5 - Reações físico-químicas e biológicas que ocorrem em uma lagoa de

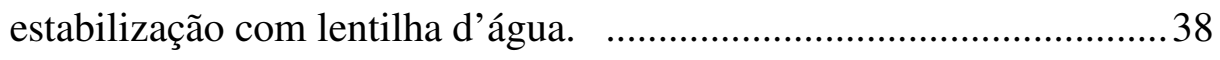

FIGURA 4.6 - Lentilha d'água em fase produtiva......................................................... 41

FIGURA 4.7 - Infestação, pela lentilha d'água, de lagoa vizinha à área do experimento

FIGURA 5.1 - Curva de resposta típica de uma lagoa sendo avaliado por meio de traçadores.

FIGURA 5.2 - Escoamento preferencial devido à estratificação térmica e ao posicionamento de dispositivos de entrada e saída - Lagoa de Estabilização Facultativa - Presidente Alves, SP. 58

FIGURA 5.3 - Curva de resposta $\mathrm{C}$ em reatores para várias extensões de agitação. Fonte: LEVENSPIEL (1974). 
FIGURA 5.4 - Fluorômetro utilizado na pesquisa - modelo FM 109525 da marca TURNER QUANTECH.

FIGURA 5.5 - Detalhes dimensionais da lagoa sem chicaneamento - Dimensões gerais e detalhe dos dispositivos de entrada e saída. 68

FIGURA 5.6 - Vista geral da lagoa sem chicaneamento. 68

FIGURA 5.7 - Análise qualitativa do escoamento hídrico para lagoa sem chicaneamento 70

FIGURA 5.8 - Análise quantitativa do escoamento hídrico para lagoa sem chicaneamento

FIGURA 5.9 - Perfis de temperatura obtidos na lagoa sem chicaneamento ao longo do período de análise hidrodinâmica. Medidas às 16 horas de cada dia. Valores médios do ponto central da lagoa conforme FIGURA 5.5 ......72

FIGURA 5.10 - Perfis de temperatura e concentração de oxigênio dissolvido obtidos na lagoa com chicaneamento longitudinal ao longo do período de análise hidrodinâmica. Medidas às 16 horas . de cada dia . Valores médios entre os dias 1/11/2002 e 11/11/2002 no ponto central da lagoa 73

FIGURA 5.11 - Variação da concentração de DQO e corante obtidos na lagoa sem chicaneamento longitudinal ao longo do período de análise hidrodinâmica. Medidas às 16 horas de cada dia. Amostras retiradas no ponto central da lagoa. 74

FIGURA 5.12 - Detalhes dimensionais da lagoa com chicanas longitudinais e foto do chicaneamento longitudinal. .75

FIGURA 5.13 - Detalhe da construção das chicanas longitudinais. .76

FIGURA 5.14 - Análise qualitativa do escoamento para lagoa com chicaneamento longitudinal. 78

FIGURA 5.15 - Análise quantitativa do escoamento para lagoa com chicaneamento longitudinal. .79

FIGURA 5.16 - Perfis de temperatura obtidos na lagoa com chicaneamento longitudinal ao longo do período de análise hidrodinâmica. Medidas às 16 horas de cada dia . Valores médios dos pontos 1,2 e 3 conforme FIGURA 5.12.

FIGURA 5.17 - Perfis de temperatura e concentração de oxigênio dissolvido obtidos na lagoa com chicaneamento longitudinal ao longo do período de análise hidrodinâmica. Medidas às 16 horas de cada dia . Valores médios entre 
os dias 9/12/2001 e 16/12/2001 nos pontos 1,2 e 3 conforme FIGURA 5.12 . 82

FIGURA 5.18 - Variação da concentração de DQO e corante obtidos na lagoa com chicaneamento longitudinal ao longo do período de análise hidrodinâmica. Medidas às 16 horas . de cada dia . Corante: valores médios entre os dias 9/12/2001 e 16/12/2001 nos pontos 1,2 e 3. Os valores de DQO foram obtidos de amostras da retirada no ponto 2 .....83

FIGURA 5.19 - Detalhes dimensionais da lagoa com chicanas longitudinais e transversais - Dimensões gerais e detalhe das chicanas transversais. .. 84

FIGURA 5.20 - Vista geral e detalhe da chicana na lagoa com chicanas longitudinais e transversais.

FIGURA 5.21 - Análise qualitativa do escoamento hídrico para lagoa com chicaneamento longitudinal e transversal. 87

FIGURA 5.22 - Croqui do chicaneamento transversal demonstrando prováveis zonas de estagnação junto às barreiras .88

FIGURA 5.23 - Análise quantitativa do escoamento hídrico para lagoa com chicaneamento longitudinal e transversal 89

FIGURA 5.24 - Perfis de temperatura obtidos na lagoa com chicaneamento longitudinal e transversal ao longo do período de análise hidrodinâmica. Medidas às 16 horas . de cada dia . Valores médios dos pontos 1,2 e 3 conforme FIGURA 5.19. 90

FIGURA 5.25 - Perfis de temperatura e concentração de oxigênio dissolvido obtido na lagoa com chicaneamento longitudinal e transversal ao longo do período de análise hidrodinâmica. Medidas às 16 horas de cada dia. Valores médios entre os dias 6/03/2002 e 14/03/2002 nos pontos 1,2 e 3 conforme FIGURA 5.19.

FIGURA 5.26 - Variação da concentração de DQO e corante obtido na lagoa com chicaneamento longitudinal e transversal ao longo do período de análise hidrodinâmica. Medidas às 16 horas de cada dia. Corante: valores médios entre os dias 06/03/2002 e 13/03/2002 nos pontos 1,2 e 3. Os valores de DQO foram obtidos de amostras da retiradas no ponto 2 ...992

FIGURA 5.27 - Comparação entre as diversas fases experimentais -Análises quantitativas e qualitativas dos experimentos. 95 
FIGURA 5.28 - Perfis de temperatura e concentração de oxigênio dissolvido obtidos nas diferentes configurações de chicaneamento ao longo do período de análise hidrodinâmica. Medidas às 16 horas de cada dia. Valor médio entre o período de cada experimento 96

FIGURA 5.29 - Variação da concentração de corante obtida na lagoa com as diversas configurações de chicaneamento ao longo do período de análise hidrodinâmica. Medidas às 16 horas de cada dia. 97

FIGURA 5.30 - Variação da concentração de DQO obtida na lagoa com as diversas configurações de chicaneamento ao longo do período de análise hidrodinâmica. Medidas às 16 horas de cada dia. .98 
TABELA 1.1 - Unidades de tratamento de esgoto operadas pela Sabesp na região noroeste do Estado de São Paulo 3

TABELA 1.2 - Resultados operacionais de lagoas de estabilização operadas pela SABESP na região noroeste do Estado de São Paulo - valores médios entre 2001e 2002 .5

TABELA 3.3 - Características operacionais das lagoas de Novo Horizonte - SP ......... 11

TABELA 3.4 - Descrição das fases experimentais e período do experimento ................. 12

TABELA 3.5 - Análises físico-químicas e bacteriológicas ............................................. 16

TABELA 4.1 - Composição química do aguapé (folhas + pecíolos) …………...............22

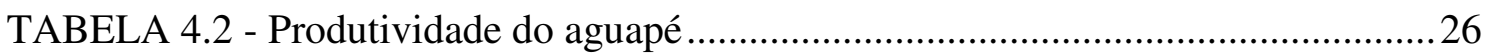

TABELA 4.3 - Número de espécies que eclodiram no tubo de amostragem da lagoa com aguapé.

TABELA 4.4 - Resultados de análises físico-químicas e bacteriológicas do esgoto afluente e efluente da lagoa de maturação com TDH = 6 dias e da lagoa com aguapé com $\mathrm{TDH}=2$ dias (valores médios)

TABELA 4.5 - Resultados de análise de turbidez do afluente e efluente da lagoa de maturação e lagoa com aguapé

TABELA 4.6 - Produtividade da lentilha d'água. 40

TABELA 4.7 - Número de indivíduos que eclodiram nos tubos de amostragem da lagoa com lentilha d'água 
TABELA 4.8 - Resultados de análises físico-químicas e bacteriológicas do esgoto afluente e efluente da lagoa de maturação com TDH $=6$ dias e da lagoa com lentilha d'água com TDH = 2 dias (valores médios)

TABELA 4.9 - Resultados da eficiência de remoção de parâmetros físico-químicos e bacteriológicos para lagoa com aguapé, lagoa com lentilha d'água e respectivamente lagoa de maturação dentro do mesmo período do experimento 48

TABELA 5.1 - Relação entre o tipo de tratamento utilizado em esgoto sanitário e faixa provável de (d) 55

TABELA 5.2 - Resultado do tempo de detenção hidráulico e Número de Dispersão (d) das lagoas de Vidigueira e Portimão, Portugal.

TABELA 5.3 - Condições básicas da operação da lagoa sem chicaneamento e resultado de análise de amostra do traçador no efluente do sistema. 69

TABELA 5.4 - Condições básicas da operação da lagoa com chicaneamento longitudinal e resultado de análise de amostra do traçador no efluente do sistema.. 77

TABELA 5.5 - Condições básicas da operação da lagoa com chicaneamento longitudinal e transversal e resultado de análise de amostra do traçador no efluente do sistema. 86

TABELA 5.6 - Comparação entre as diversas fases experimentais...... .94 


\begin{tabular}{ll}
$\sigma_{t}^{2}-$ & Variança adimensional \\
$\delta^{2}-$ & Variança da curva Ci x Ti em unidades de tempo \\
C - & Concentração do traçador na saída \\
Co - & Massa do traçador injetado dividida pelo volume útil da lagoa \\
CONAMA - & Conselho Nacional do Meio Ambiente \\
d - & Número de Dispersão \\
DBO - & Demanda Bioquímica de Oxigênio em 05 dias \\
DQO - & Demanda Química de Oxigênio \\
DTR - & Distribuição dos tempos de residências \\
ETA - & Estação de Tratamento de Água \\
ETE - & Estação de Tratamento de Esgoto \\
ha - & hectare \\
K - & Lanstante de remoção \\
LAN - & Lagoa Anaeróbia \\
LF - & Lagoa Maturação \\
\hline
\end{tabular}




\begin{tabular}{|c|c|}
\hline NMP - & Número Mais Provável \\
\hline NT - & Nitrogênio Total \\
\hline OD - & Oxigênio Dissolvido \\
\hline $\mathrm{P}_{\text {total }}-$ & Fósforo Total \\
\hline Q - & Vazão \\
\hline $\mathrm{S}-$ & Concentração do substrato no efluente \\
\hline $\mathrm{S}_{\mathrm{o}}-$ & Concentração do substrato no afluente \\
\hline SSV - & Sólidos Suspensos Voláteis \\
\hline SST - & Sólidos Suspensos Totais \\
\hline SABESP - & Companhia de Saneamento Básico do Estado de São Paulo \\
\hline $\mathrm{t}-$ & Tempo \\
\hline TDH - & Tempo de detenção hidráulico teórico \\
\hline TDR - & Tempo de detenção hidráulico real \\
\hline$t_{m}-$ & Tempo médio de residência do fluído \\
\hline ton - & Toneladas \\
\hline V- & Volume \\
\hline
\end{tabular}




\section{$\boldsymbol{R}_{\text {esumo }}$}

POLISEL, K. C. (2005). Desempenho de lagoas de maturação utilizando macrófitas aquáticas e chicaneamento Tese (Doutorado) - Escola de Engenharia de São Carlos, Universidade de São Paulo, São Carlos, 2005.

As lagoas de estabilização têm sido, por suas características operacionais e baixos custos de implantação, consideradas como a opção mais viável para tratamento de águas residuárias em pequenas e médias comunidades. O sistema composto por lagoa anaeróbia e facultativa em série é o mais empregado no Brasil. Com o avanço no monitoramento das Lagoas de Estabilização que se iniciou na década de 90, no caso do Estado de São Paulo pela SABESP, e que hoje se encontra bastante estruturado, periódico e confiável, nota-se que esses sistemas apesar de projetados seguindo as técnicas mais recentes, não possuem a eficiência esperada quando em operação. Tornam-se então prementes os estudos no sentido de melhorar o desempenho dos sistemas existentes e fornecer subsídios para novos projetos de lagoas de estabilização. Este trabalho estudou a utilização de chicaneamento nas lagoas de estabilização verificando a influência das chicanas no comportamento hidrodinâmico e desempenho desses sistemas além da utilização de macrófitas aquáticas no processo de tratamento de águas residuárias. Concluiu-se que mesmo com aumento de eficiência de remoção de DQO, $\mathrm{DBO}_{5}$, Nitrogênio Kjedahl e Amoniacal, para ambos os casos: lagoa com aguapé e lagoa com lentilha d'água, os inúmeros problemas operacionais e aumento de custos que surgiram da aplicação das macrófitas aquáticas tornam desaconselhável o uso de aguapé e lentilha d'água em lagoas de tratamento de esgoto. Com relação ao chicaneamento o sistema que mais se aproximou dos valores teóricos, com relação ao tempo de detenção hidráulico e Número de Dispersão (d), foi a lagoa com chicaneamento longitudinal, melhorando o comportamento hidráulico do sistema, podendo ser considerado uma medida simples e de baixo custo para incrementar a eficiência de lagoas de estabilização.

Palavras-chave: lagoas de estabilização, estratificação térmica, chicaneamento, macrófitas aquáticas. 


\section{$A_{\text {ssreact }}$}

POLISEL, K. C. (2005). Performance of maturation ponds using aquatic plants and baffles. PhD. Thesis - Escola de Engenharia de São Carlos, Universidade de São Paulo, São Carlos, 2005.

Due to the operational characteristics and low investment costs stabilization ponds have been considered as the most viable option for wastewater treatment in small and medium size communities. Anaerobic and facultative ponds in series are the most used in Brazil. With the progress of monitoring of the stabilization ponds, that was initiated in the decade of 1990 in the State of São Paulo by SABESP, it was observed that these systems do not possess the expected efficiency when in operation, although they were designed following the best available knowledge at that time. Thus, new studies were direct to improve the performance of the existing systems and to supply subsidies for new projects of stabilization ponds. This research examines, separately, the use of baffles and macrophytes in a pilot scale stabilization pond verifying the influence of these elements on the hydrodynamic behavior and performance of the wastewater treatment. It was concluded that although there is an increase in removal efficiency of DQO, $\mathrm{DBO}_{5}$, Nitrogen Kjedahl and ammoniacal, the several operational problems and increase of costs that had appeared with the application of water hyacinths and duckweed in the pond, it is not recommended to use these aquatic plants in sewer treatment. Concerning the use of baffles the system that came closer to the theoretical values, in relation to the hydraulic time of detention and Number of Dispersion (d), was the pond with longitudinal baffles. These baffles improved the hydraulic behavior of the system and are a simple measure and of low cost to develop the efficiency of stabilization ponds.

Keywords: stabilization ponds, thermal stratification, baffles, aquatic plants. 
O crescimento das cidades associado a exigências ambientais cada vez mais rigorosas e à crescente conscientização da população quanto a importância dos recursos naturais aceleraram, na década de 1980, o projeto e implantação de sistemas de tratamento de esgoto nas pequenas e médias comunidades do Estado de São Paulo.

No período inicial de instalação das Estações de Tratamento de Esgoto, os projetos tinham em sua concepção a preocupação em reduzir o impacto ambiental gerado pelo lançamento das águas residuárias "in natura" nos corpos receptores, por meio da construção de sistemas com custo compatível com a capacidade de pagamento da população beneficiada. Até então, os fatores custos de implantação, operação e minimização do impacto ambiental, eram os preponderantes na definição dos tipos de sistemas de tratamento de águas residuárias a serem empregados nas pequenas e médias comunidades (HERRERA, 2000) ${ }^{1}$. Desse modo, as lagoas de estabilização demonstraram ser o sistema mais adequado, pois possuem um ecossistema autosuficiente que não recebe qualquer interferência direta do homem (MARECOS DO MONTE E MARA, 1987), com baixo custo operacional e de construção.

Com base nessa filosofia iniciou-se a implantação, em larga escala, de lagoas de estabilização em pequenas e médias comunidades, sendo que, a título de exemplo, foram construídas pela SABESP, na região Noroeste do Estado de São Paulo, 70 unidades de tratamento de esgotos compostos de lagoas de estabilização (TABELA

\footnotetext{
${ }^{1}$ HERRERA, João - Gerente do Departamento de Projetos da SABESP - Unidade Regional do Baixo Tietê e Grande - palestra proferida em 02/2002, em Lins.
} 
1.1), sendo o tipo Sistema Australiano o mais empregado.

Nessa fase, havia pouca preocupação, além de grande dificuldade, em realizar monitoramento desses sistemas, pois não havia laboratórios equipados e disponíveis para análises de rotina, o que dificultava a verificação do desempenho das lagoas de estabilização frente ao exigido pela Legislação Brasileira. Essa situação se alterou substancialmente no final da última década e início do século 21 , mudando radicalmente a visão dos projetistas e operadores de sistema de tratamento.

Em meados da década de 1990, então com grande número de comunidades com sistemas de tratamento de esgoto implantado, iniciaram-se investimentos na construção de laboratórios de controle de qualidade de efluentes, estabelecendo rotinas de análise para acompanhamento do desempenho operacional. Essa nova realidade proporcionou melhor conhecimento dos resultados operacionais das lagoas de estabilização que, aliado à rigorosa Legislação Ambiental Brasileira vigente, mudou o enfoque dos projetistas e operadores do sistema de tratamento de águas residuárias em relação à configuração de novos sistemas, alterando o objetivo que antes estava centralizado em custos e redução de impacto ambiental, incluindo-se agora a preocupação com o atendimento efetivo à legislação.

Sabe-se hoje que os resultados obtidos no tratamento de águas residuárias através de lagoas de estabilização estão aquém do exigido pela bastante restritiva Legislação Ambiental Brasileira quanto à emissão de efluentes e classe dos rios (TABELA 1.2). Tem-se, por exemplo, a Resolução CONAMA no 357 que estabelece o teor máximo de Fosfato Total em 0,030 mg/l para corpos d'água classe 2, muito restritivo para se alcançar, utilizando apenas sistemas de tratamento de lagoas de estabilização em série, tendo em vista os efluentes possuírem elevado teor de fósforo e os corpos receptores, em sua maioria, terem pequena capacidade de diluição.

PIVELLI E PEREIRA (2003), em estudos das condições operacionais do sistema de tratamento por lagoas de estabilização da cidade de Lins-SP concluíram que esse sistema de tratamento não apresentou resultados de eficiência de remoção de poluentes químicos e contaminantes biológicos a ponto de atender à legislação vigente principalmente quando a descarga é efetuada em corpos d'água de baixa vazão.

Outro fato que deve ser levado em conta pelos profissionais do Setor de Saneamento responsáveis por projetos, construção e operação de sistemas de tratamento

\footnotetext{
${ }^{2}$ ETE composta de uma lagoa anaeróbia seguida de uma lagoa facultativa. Eventualmente, há tratamento preliminar de gradeamento e caixa de areia.
} 
de águas residuárias é a Lei de Crimes Ambientais n. ${ }^{\circ} 9605$ de 12/02/98 que dispõe sobre sanções penais e administrativas derivadas de conduta e atividades lesivas ao meio ambiente, atribuindo ao poluidor a responsabilidade penal ambiental. Sabe-se que estão em andamento inúmeras ações criminais contra profissionais de saneamento que decorrem de danos ambientais provocados por lançamento inadequado de efluentes.

Em resumo, há a necessidade premente de melhoria dos sistemas de tratamento de esgoto composto por lagoas de estabilização, que geram um passivo ambiental de R $\$$ 14.000.000,00, somente em sistemas em operação no noroeste do Estado de São Paulo $(\text { ALMEIDA NETO, 2001) })^{3}$, recursos esses necessários para incremento de seu desempenho de maneira a atender à legislação vigente.

Este trabalho englobou pesquisas visando a melhoria do desempenho de lagoas de estabilização através de processos físicos, que interfiram na hidrodinâmica e no processo de estratificação térmica, e biológicos, com a introdução de plantas aquáticas no processo de depuração.

Dado que o texto desta tese não apresenta a estrutura convencional, optou-se por não apresentar uma revisão bibliográfica única, mas incluir ao longo do texto as referências e comentários quando eles se fazem necessários.

TABELA 1.1 - Unidades de tratamento de esgoto operadas pela Sabesp na região noroeste do Estado de S Paulo

\begin{tabular}{c|c|c|c|c}
\hline \multicolumn{5}{c}{ RT - Unidade de Negócio Baixo Tietê e Grande } \\
\hline & Comunidades Operadas & Data de Implantação & Tipo de Tratamento & Vazão Trat. (l/s) \\
\hline 1 & ADOLFO & 1994 & LAN+LF & 4,00 \\
2 & ALTO ALEGRE & 1979 & LAN+LF & 2,50 \\
3 & ÁLVARES FLORENCE & 1992 & $2 \mathrm{LF}$ & 3,00 \\
4 & APARECIDA D'OESTE & 1990 & LF & 4,00 \\
5 & ASPÁSIA & 1996 & LF & 1,16 \\
6 & AURIFLAMA & 1998 & LAN+LF1+LF2 & 12,00 \\
7 & AVAÍ & 1990 & LF & 3,00 \\
8 & BENTO DE ABREU & 1979 & LF & 3,00 \\
9 & BREJO ALEGRE & 2001 & LAN+LF & 1,82 \\
10 & CAJOBI & 1992 & LF & 9,50 \\
\hline 11 & CÂNDIDO RODRIGUES & 1985 & LF & 2,50 \\
12 & COROADOS & 1996 & LF & 4,00 \\
13 & DIRCE REIS & 1994 & LF & 1,00 \\
14 & DOLCINÓPOLIS & 1980 & LF & 2,00 \\
15 & EMBAÚBA & 1994 & LF & 2,00 \\
16 & ESTRELA D'OESTE & 1982 & LAN+LF & 8,00 \\
17 & FERNANDÓPOLIS & 1998 & LAN+LF+LM & 60,00 \\
18 & FLOREAL & 1992 & & 4,00 \\
20 & GENERAL SALGADO & 2001 & & 17,64 \\
\hline
\end{tabular}

\footnotetext{
${ }^{3}$ ALMEIDA NETO, Luiz Paulo - Gerente do Departamento Técnico da SABESP - U.N. Baixo Tiete e Grande - palestra ministrada em 07/06/2002.
} 


\begin{tabular}{|c|c|c|c|c|}
\hline & $\begin{array}{c}\text { Comunidades } \\
\text { Operadas }\end{array}$ & Data de Implantação & $\begin{array}{c}\text { Tipo de } \\
\text { Tratamento }\end{array}$ & $\begin{array}{c}\text { Vazão } \\
\text { Trat-(1/s) }\end{array}$ \\
\hline 21 & GUARANI D'OESTE & 1976 & $\mathrm{LF}$ & 3,00 \\
\hline 22 & GUZOLÂNDIA & 2000 & $\mathrm{LAN}+\mathrm{LF}$ & 1,90 \\
\hline 23 & IBIRÁ & 1982 & $\mathrm{LF}$ & 8,00 \\
\hline 24 & INDIAPORÃ & 1976 & $\mathrm{LF}$ & 2,00 \\
\hline 25 & IRAPUÃ & 1995 & $\mathrm{LAN}+\mathrm{LF}$ & 6,00 \\
\hline 26 & JALES & 200 & $\mathrm{LAN}+\mathrm{LF}$ & 52,00 \\
\hline 27 & LINS & 1996 & $3 \mathrm{LAN}+3 \mathrm{LF}$ & 93,00 \\
\hline 28 & LOURDES & 1997 & $\mathrm{LF}$ & 2,00 \\
\hline 29 & MACEDÔNIA & 1979 & LF & 3,00 \\
\hline 30 & MARINÓPOLIS & 1993 & LF & 2,00 \\
\hline 31 & MERIDIANO & 1985 & LAN+LF+LM & 3,60 \\
\hline 32 & MESÓPOLIS & 2001 & $\mathrm{LAN}+\mathrm{LF}+\mathrm{LM} 1+\mathrm{LM} 2$ & 2,00 \\
\hline 33 & MIRA ESTRELA & 1982 & LF & 2,00 \\
\hline 34 & MONCÕES & 1990 & $\mathrm{LAN}+\mathrm{LF}$ & 2,00 \\
\hline 35 & MONTE APRAZÍVEL & 1989 & LAN & 20,00 \\
\hline 36 & NHANDEARA & 1976 & $\mathrm{LF}$ & 10,00 \\
\hline 37 & NIPOÃ & 1994 & $\mathrm{LAN}+\mathrm{LF}$ & 3,00 \\
\hline 38 & NOVA CANAÃ PAULISTA & 2002 & $\mathrm{LF}+\mathrm{LM}$ & 0,77 \\
\hline 39 & NOVA GRANADA & 1994 & $\mathrm{LAN}+\mathrm{LF}$ & 18,00 \\
\hline 40 & NOVA LUZITÂNIA & 1990 & $\mathrm{LAN}+\mathrm{LF}$ & 2,00 \\
\hline 41 & NOVO HORIZONTE & 1990 & $2 \mathrm{LAN}+2 \mathrm{LF}(55)$ & 24,65 \\
\hline 42 & ONDA VERDE & 1983 & $\mathrm{LF}$ & 3,00 \\
\hline 43 & ORINDIÚVA & 1980 & LF & 4,00 \\
\hline 44 & OUROESTE & 1976 & LF & 6,00 \\
\hline 45 & PALMEIRA D'OESTE & 2001 & $\mathrm{LAN}+\mathrm{LF} 1+\mathrm{LF} 2+\mathrm{LM}$ & 9,00 \\
\hline 46 & PARANAPUÃ & 1990 & $\mathrm{LAN}+\mathrm{LF}$ & 3,00 \\
\hline 47 & PAULO DE FARIA & 1999 & $\mathrm{LAN}+\mathrm{LF} 1+\mathrm{LF} 2$ & 4,20 \\
\hline 48 & PEDRANÓPOLIS & 1989 & $\mathrm{TF}$ & 2,00 \\
\hline 49 & PIRATININGA & 1992 & $\mathrm{LAN}+\mathrm{LF}+2 \mathrm{LM}+\mathrm{FP}$ & 11,00 \\
\hline 50 & PLANALTO & 1989 & $\mathrm{LF}$ & 3,00 \\
\hline 51 & POLONI & 1977 & LF & 6,00 \\
\hline 52 & PONGAÍ & 1999 & LAN+LF+LM & 1,05 \\
\hline 53 & PONTALINDA & 2000 & $\mathrm{LAN}+\mathrm{LF}+\mathrm{LM}$ & 5,90 \\
\hline 54 & PONTES GESTAL & 1982 & $\mathrm{LF}$ & 3,00 \\
\hline 55 & PRESIDENTE ALVES & 1996 & $\mathrm{LAN}+\mathrm{LF} 1+\mathrm{LF} 2$ & 3,00 \\
\hline 56 & RIOLÂNDIA & 1981 & $\mathrm{LAN}+\mathrm{LF} 1$ & 6,00 \\
\hline 57 & RUBIÁCEA & 1981 & $\mathrm{LF}$ & 2,00 \\
\hline 58 & RUBINÉIA & 1981 & $\mathrm{LF}$ & 2,00 \\
\hline 59 & SANTA ALBERTINA & 1989 & LAN+LF+LM & 5,00 \\
\hline 60 & SANTA CLARA D'OESTE & 1999 & LF & 3,00 \\
\hline 61 & SANTANA DA PONTE PENSA & 1993 & LF & 2,00 \\
\hline 62 & $\begin{array}{l}\text { SÃO JOÃO DAS DUAS } \\
\text { PONTES }\end{array}$ & 1989 & $\mathrm{LF}$ & 2,00 \\
\hline 63 & SEBASTIANÓPOLIS DO SUL & 1993 & LF & 2,00 \\
\hline 64 & SUD MENUCCI & 1992 & $\mathrm{LAN}+\mathrm{LF}$ & 6,00 \\
\hline 65 & TRÊS FRONTEIRAS & 1993 & $\mathrm{LF}$ & 5,00 \\
\hline 66 & TURIÚBA & 1981 & LF & 2,00 \\
\hline 67 & TURMALINA & 1981 & $\mathrm{LF}$ & 2,00 \\
\hline 68 & URÂNIA & 1974 & $\mathrm{LA}+\mathrm{LF}$ & 8,00 \\
\hline 69 & VALENTIM GENTIL & 1976 & $\mathrm{LF}$ & 9,00 \\
\hline 70 & ZACARIAS & 1998 & LF & 0,80 \\
\hline
\end{tabular}

Fonte: SABESP (2003) 
TABELA 1.2 -Resultados operacionais de lagoas de estabilização operadas pela SABESP na região noroeste do Estado de São Paulo - valores médios entre 2001 e 2002 - ( 06 coletas no período )

\begin{tabular}{|c|c|c|c|c|c|c|c|c|c|c|c|c|c|c|c|}
\hline \multicolumn{2}{|c|}{ Lagoa } & $\begin{array}{c}\mathrm{DBO}_{5}{ }^{20} \\
(\mathrm{mg} \\
\left.\mathrm{O}_{2} / \mathrm{l}\right)\end{array}$ & $\begin{array}{c}\text { DQO } \\
\left(\mathrm{mgO}_{2} / \mathrm{l}\right)\end{array}$ & $\begin{array}{l}\text { Sólidos } \\
\text { Totais } \\
(\mathrm{mg} / \mathrm{l})\end{array}$ & $\begin{array}{c}\text { Sólidos } \\
\text { Totais } \\
\text { Voláteis } \\
(\mathrm{mg} / \mathrm{l})\end{array}$ & $\begin{array}{c}\text { Sólidos } \\
\text { Totais } \\
\text { Fixos } \\
(\mathrm{mg} / \mathrm{l})\end{array}$ & $\begin{array}{c}\text { Sólidos } \\
\text { Suspensão } \\
\text { Totais } \\
(\mathrm{mg} / \mathrm{l})\end{array}$ & $\begin{array}{c}\text { Sólidos } \\
\text { Suspensão } \\
\text { Voláteis } \\
(\mathrm{mg} / \mathrm{l})\end{array}$ & $\begin{array}{c}\text { Sólidos } \\
\text { Suspensão } \\
\text { Fixos } \\
(\mathrm{mg} / \mathrm{l})\end{array}$ & $\begin{array}{c}\text { Sólidos } \\
\text { Sedimentaveis } \\
(\mathrm{ml} / \mathrm{l})\end{array}$ & $\begin{array}{c}\text { Fosforo } \\
\text { Total } \\
(\mathrm{mg} / 1)\end{array}$ & $\begin{array}{c}\text { Coliformes } \\
\text { Totais } \\
\text { NMP/100ml }\end{array}$ & $\begin{array}{c}\text { Vazão } \\
\text { media } \\
\text { Afluente } \\
\left(\mathrm{m}^{3} / \text { dia }\right)\end{array}$ & \begin{tabular}{c|} 
Tempo \\
Detenção \\
Hidráulica \\
Total \\
(dias) \\
\end{tabular} & $\begin{array}{c}\text { Ano } \\
\text { Construção }\end{array}$ \\
\hline \multirow{2}{*}{1} & $\mathbf{A F}$ & 326 & 779 & 982 & 548 & 434 & 433 & 278 & 155 & 8 & 10,2 & $7.10^{7}$ & \multirow{2}{*}{576} & \multirow{2}{*}{39} & \multirow{2}{*}{1999} \\
\hline & EF & 30 & 217 & 575 & 238 & 337 & 108 & 72 & 36 & 0 & 6,4 & $3.10^{6}$ & & & \\
\hline \multirow{2}{*}{2} & $\mathbf{A F}$ & 624 & 1402 & 1052 & 650 & 402 & 380 & 318 & 62 & 7 & 8,9 & $6.10^{8}$ & \multirow{2}{*}{1662} & \multirow{2}{*}{20} & \multirow{2}{*}{1982} \\
\hline & $\mathbf{E F}$ & 120 & 901 & 869 & 585 & 284 & 145 & 118 & 27 & 0 & 7,4 & $2.10^{6}$ & & & \\
\hline \multirow[t]{2}{*}{3} & $\mathbf{A F}$ & 487 & 1127 & 978 & 624 & 354 & 370 & 323 & 47 & 9 & 9 & $2.10^{8}$ & \multirow{2}{*}{528} & \multirow{2}{*}{36} & \multirow{2}{*}{1996} \\
\hline & EF & 97 & 260 & 494 & 234 & 260 & 97 & 81 & 16 & 0 & 6,6 & $1.10^{6}$ & & & \\
\hline \multirow{2}{*}{4} & $\mathbf{A F}$ & 528 & 1316 & 1176 & 787 & 389 & 404 & 302 & 102 & 9 & 8,6 & $2.10^{8}$ & \multirow{2}{*}{543} & \multirow{2}{*}{59} & \multirow{2}{*}{1984} \\
\hline & $\mathbf{E F}$ & 68 & 421 & 646 & 328 & 318 & 157 & 144 & 13 & 0 & 6,8 & $4.10^{5}$ & & & \\
\hline \multirow{2}{*}{5} & $\mathbf{A F}$ & 524 & 1253 & 1278 & 829 & 449 & 439 & 359 & 80 & 8 & 9,2 & $2.10^{8}$ & \multirow{2}{*}{6765} & \multirow{2}{*}{23} & \multirow{2}{*}{1999} \\
\hline & $\mathbf{E F}$ & 73 & 263 & 597 & 246 & 351 & 151 & 128 & 23 & 0 & 7,9 & $3.10^{6}$ & & & \\
\hline \multirow{2}{*}{6} & $\mathbf{A F}$ & 507 & 1048 & 783 & 464 & 319 & 561 & 464 & 97 & 8 & 11,2 & $1.10^{8}$ & \multirow[t]{2}{*}{1765} & \multirow[t]{2}{*}{24} & \multirow[t]{2}{*}{1991} \\
\hline & $\mathbf{E F}$ & 47 & 180 & 428 & 194 & 234 & 207 & 194 & 13 & 0 & 9,9 & $5.10^{6}$ & & & \\
\hline
\end{tabular}

AF - Esgoto Bruto - Afluente

EF - Esgoto Tratado - Efluente

Fonte : SABESP (2002) 
Esta pesquisa teve como objetivos:

- Desenvolvimento de lagoa de estabilização, utilizando macrófitas aquáticas: aguapé e lentilha d'água e as vantagens e desvantagens da utilização dessas plantas no processo de depuração do esgoto sanitário.

- Avaliar o fenômeno de estratificação térmica de uma lagoa facultativa secundária, em escala piloto, tratando esgoto sanitário proveniente do sistema de coleta da cidade de Novo Horizonte, SP utilizando dois tipos de chicaneamento: longitudinal e longitudinal e transversal, e compará-los com sistema sem chicaneamento. 


\section{PROCEDIMENTOS EXPERIMENTAIS}

\subsection{Caracterização do local de pesquisa}

A pesquisa constitui-se de experimentos que foram realizados na cidade de Novo Horizonte situada à noroeste do Estado de São Paulo.

O município está inserido na bacia hidrográfica do Baixo Tietê, sendo que essa região possui clima tropical quente e seco, com chuvas no verão, e precipitação média mensal no verão de $120 \mathrm{~mm}$ e no inverno de $30 \mathrm{~mm}$ e temperatura média anual de $27^{\circ}$ C. A sede do município encontra-se a $451 \mathrm{~m}$ acima do nível do mar e apresenta coordenadas UTM N 8.582 E 799.346.

\subsection{Estação de tratamento piloto}

Para realização dos experimentos deveria ser escolhido um sistema de tratamento composto de lagoas em série que apresentasse condições topográficas favoráveis à instalação de uma estação piloto, possibilitando o recebimento do esgoto por gravidade, sem necessidade de bombeamento, e que possuísse sistema terciário. Sendo assim, foi utilizado o sistema de tratamento da cidade de Novo Horizonte que atende a estas exigências.

Foi construída uma lagoa em concreto, paralela ao sistema terciário, com as seguintes características:

Largura na profundidade média: $04 \mathrm{~m}$.

Comprimento na profundidade média : $14 \mathrm{~m}$.

Profundidade útil: $1,2 \mathrm{~m}$. 
Volume: $46,8 \mathrm{~m}^{3} /$ Inclinação do talude: $30^{\circ}$

A lagoa foi totalmente revestida em concreto com barreiras externas em alvenaria de maneira a impedir a entrada de água pluvial (FIGURAS 3.1 e 3.2).

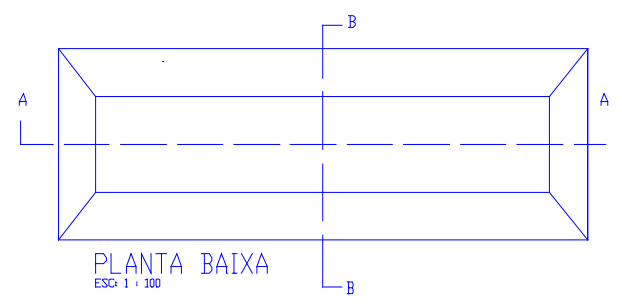

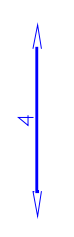

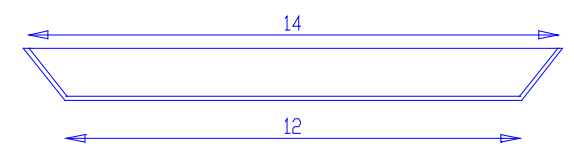

CDRTE AA

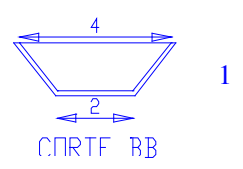

FIGURA 3.1 - Detalhes construtivos da lagoa experimental

A posição da lagoa experimental era lateral à lagoa de maturação, recebendo o mesmo afluente deste sistema, que chegava à lagoa através da caixa de distribuição central (FIGURAS 3.3 e 3.4).

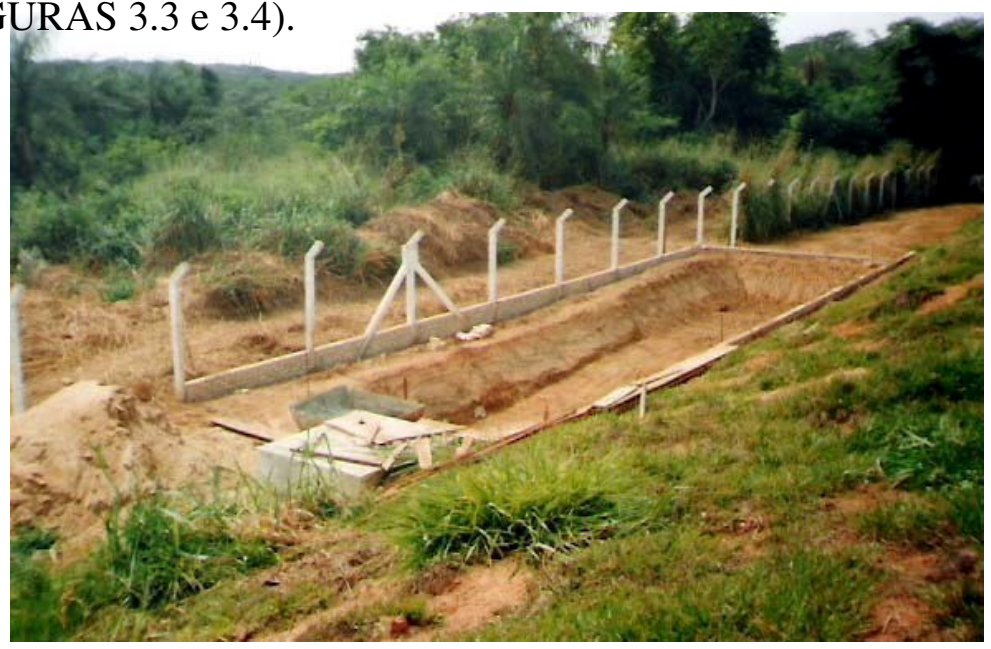

FIGURA 3.2 - Lagoa experimental em construção 


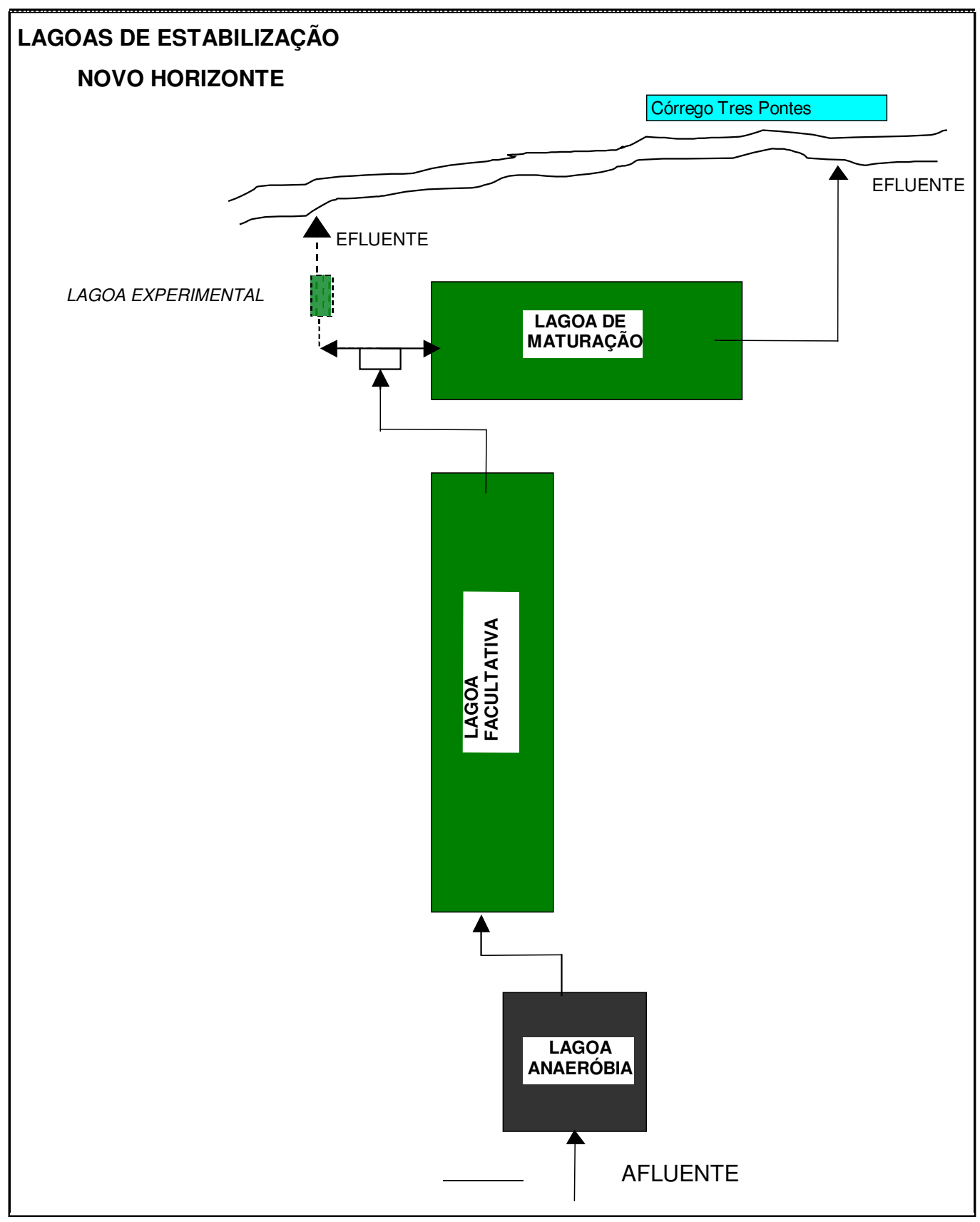

FIGURA 3.3 - Croqui das lagoas de estabilização de Novo Horizonte e posicionamento da lagoa experimental 


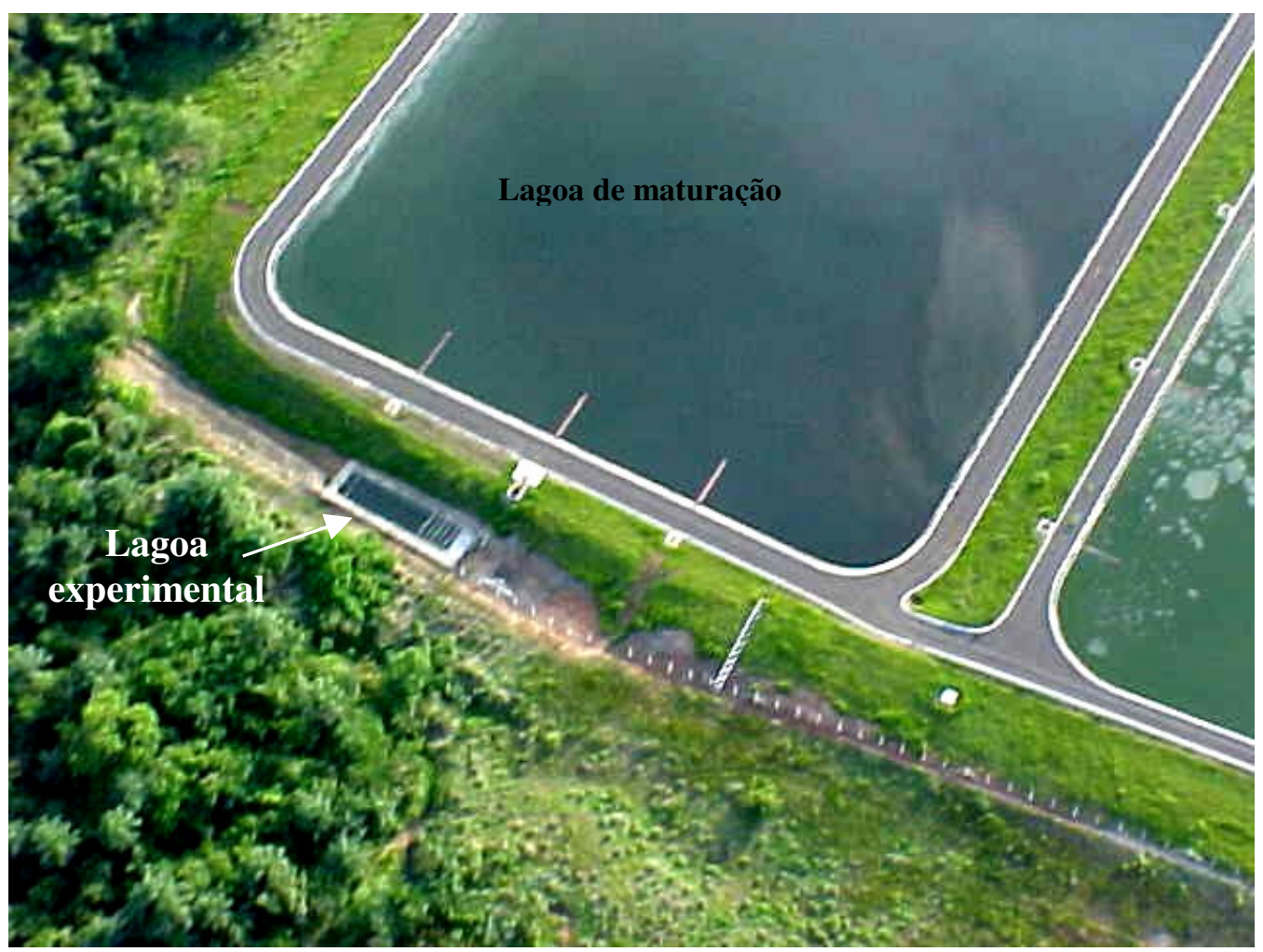

FIGURA 3.4 - Vista da lagoa experimental e lagoa de maturação - Foto: Arquivos da Sabesp

\subsection{Esgoto utilizado}

O sistema de tratamento (FIGURA 3.5), projetado pela Sabesp, é constituido de tratamento preliminar (caixa de areia e gradeamento) medidor de vazão (calha Parshall) e três lagoas em série, sendo a primeira anaeróbia seguida de lagoa facultativa e de lagoa de maturação. O esgoto bruto afluente possui uma vazão de $4.550 \mathrm{~m}^{3} /$ dia com uma $\mathrm{DBO}_{5}$ de $524 \mathrm{mg} / \mathrm{l}$ e DQO de $1.253 \mathrm{mg} / \mathrm{l}$ (valores médios).

As características do sistema são representadas pela TABELA 3.3. 
TABELA 3.3 - Características operacionais das lagoas de Novo Horizonte - SP

\begin{tabular}{|c|c|c|c|}
\hline & $\begin{array}{c}\text { Lagoa } \\
\text { Anaeróbia }\end{array}$ & $\begin{array}{c}\text { Lagoa } \\
\text { Facultativa }\end{array}$ & $\begin{array}{c}\text { Lagoa } \\
\text { Maturação }\end{array}$ \\
\hline Área (ha) & 0,5 & 1,96 & 1,94 \\
\hline Volume $\mathrm{m}^{3}$ & 15000 & 29300 & 28384 \\
\hline $\begin{array}{c}\text { Tempo detenção hidráulico } \\
\text { teórico }(\mathrm{d})\end{array}$ & 3 & 6 & 6 \\
\hline $\begin{array}{l}\text { Taxa aplicação } \\
\mathrm{kg} \mathrm{DBO}_{5} / \mathrm{ha} / \text { dia }\end{array}$ & 3000 & 207 & 94 \\
\hline Remoção de $\mathrm{DBO}_{5}(\%)$ & 73 & 55 & - \\
\hline
\end{tabular}

Fonte: SABESP (2001)

A porcentagem de remoção de coliformes entre o afluente e o efluente final é da ordem de $98,4 \%$, ainda bastante baixa.

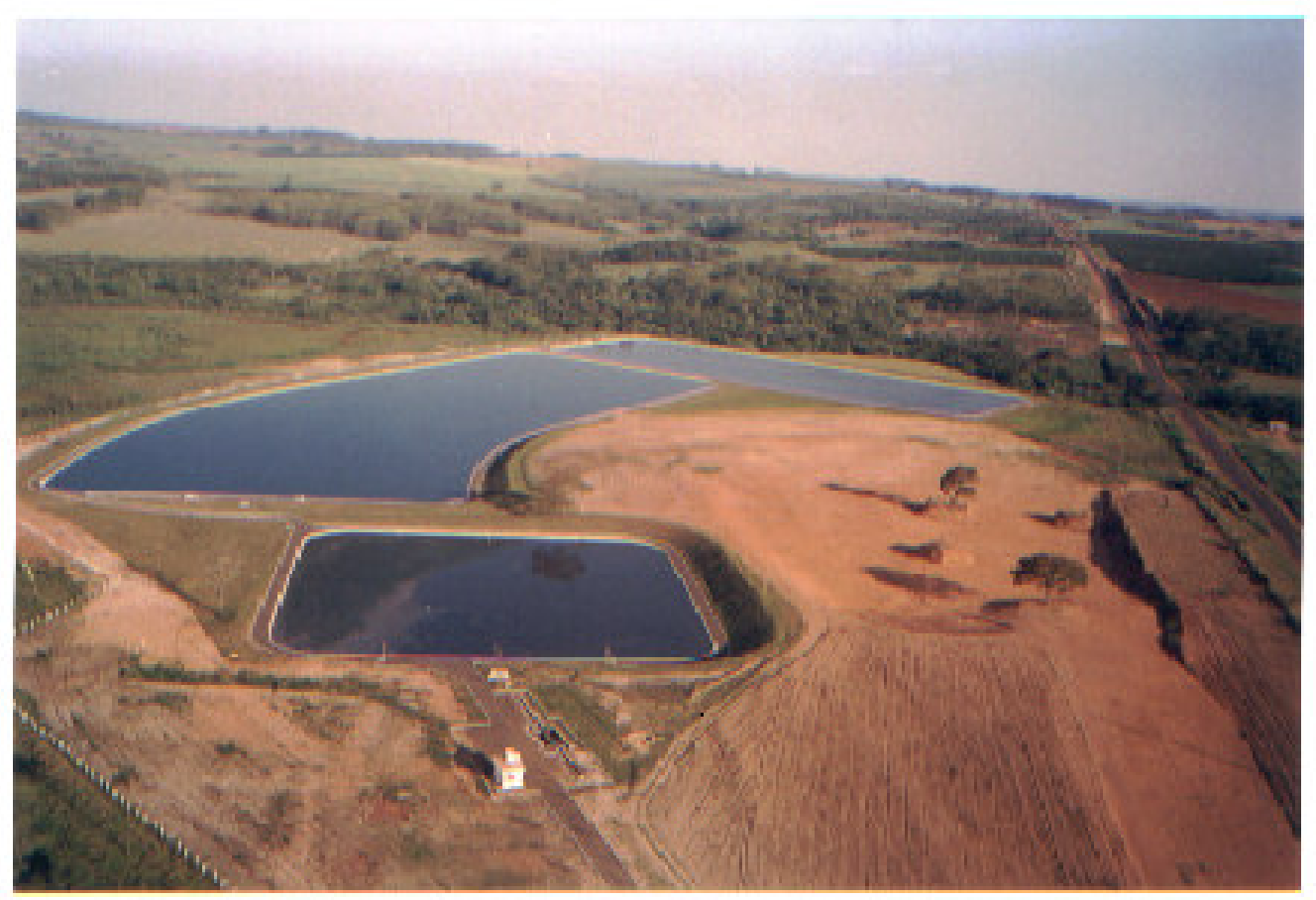

FIGURA 3.5 - Vista aérea da Estação de Tratamento de Esgoto - Novo Horizonte, SP - Foto: Arquivo da Sabesp. 


\subsection{Descrição das fases experimentais}

Este trabalho de pesquisa constitui-se de cinco experimentos subseqüentes, conforme TABELA 3.4 .

TABELA 3.4 - Descrição das fases experimentais e período do experimento

\begin{tabular}{|c|c|c|c|c|}
\hline \multirow{2}{*}{ Experimento } & \multirow{2}{*}{ Tipo } & \multicolumn{2}{|c|}{ Período } & \multirow{2}{*}{$\begin{array}{r}\text { Total } \\
\text { (dias) }\end{array}$} \\
\hline & & início & término & \\
\hline $\mathrm{I}$ & Aplicação de aguapé & $10 / 2000$ & $01 / 2001$ & 120 \\
\hline II & Aplicação de lentilha d'água & $03 / 2001$ & $08 / 2001$ & 150 \\
\hline III & Aplicação de chicana longitudinal & $11 / 2001$ & $03 / 2002$ & 120 \\
\hline IV & $\begin{array}{l}\text { Aplicação de chicana } \\
\text { longitudinal/transversal }\end{array}$ & $05 / 2002$ & $08 / 2002$ & 120 \\
\hline $\mathrm{V}$ & Sem chicanas (controle) & $10 / 2002$ & $01 / 2003$ & 120 \\
\hline
\end{tabular}

A realização dos experimentos ocorreu de forma particular para cada um distintamente, sendo comum para todos eles os procedimentos de preparação da lagoa experimental, o método de medição da vazão afluente e o período de adaptação da lagoa antes do início das análises.

\subsection{Alimentação do esgoto}

\subsubsection{Preparação da lagoa}

No início de cada fase, a lagoa era preenchida com esgoto através de bombeamento do efluente da lagoa facultativa, numa operação que durou em torno de duas horas, de modo a permitir a imediata operação do sistema após a carga.

Este processo permitiu que não houvesse variação nas condições biológicas que poderiam ser provocadas pela carga volumétrica lenta e conseqüente variação de lâmina d'água, temperatura e qualidade do afluente.

Após o término de cada fase do experimento, a lagoa foi drenada por meio de 
caminhão equipado com tanque a vácuo e posteriormente lavada (FIGURA 3.6). O enchimento ocorria novamente quando do início do próximo experimento, obedecendo aos critérios descritos acima. Tal método visou impedir a influência de um experimento sobre o outro devido a materiais sedimentados e partículas em suspensão e ainda garantir período de adaptação da lagoa idêntica para todos os experimentos (vide 3.5.2).

O processo obedeceu a seguinte seqüência para cada experimento:

- Alimentação da lagoa por bombeamento até o nível de operação.

- Abertura do tubo alimentador da lagoa.

- Abertura do dispositivo de medição e calibração da vazão afluente.

- Limpeza e calibração do dispositivo de medição diariamente durante o período de adaptação.

- Realização do experimento.

- Drenagem da lagoa e lavagem das paredes e piso.

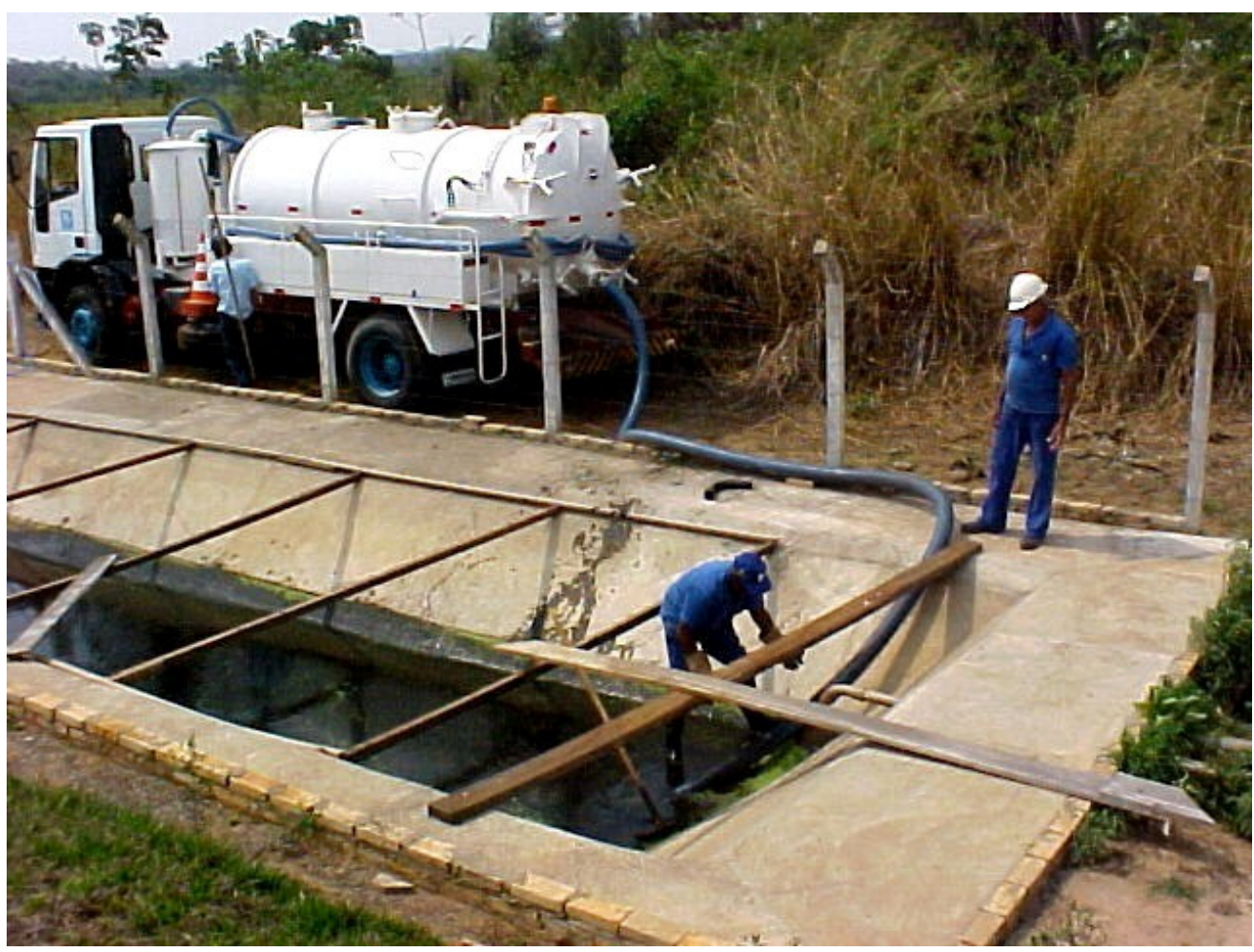

FIGURA 3.6 - Método de limpeza da lagoa ao final de cada experimento

\subsubsection{Período de adaptação da lagoa}

O período de adaptação da lagoa, antes do início de cada experimento, foi 
determinado pelo experimento I, que corresponde à utilização do aguapé.

O experimento I iniciou-se logo após o carregamento da lagoa com a introdução do aguapé. O aguapé foi retirado do seu habitat natural por redes e o sistema foi preenchido pela planta em uma área correspondente a $20 \%$ da sua área superficial total. Aguardou-se, então, a reprodução e a total predominação do aguapé sobre outras espécies de plantas que o acompanharam quando da sua retirada do seu habitat.

A inspeção visual demonstrou que, após 60 dias, a lagoa estava completamente tomada pela planta e havia o completo desaparecimento de outras espécies. Adotou-se, assim, o período de adaptação de 60 dias, antes do início de todas as fases experimentais que precederam a esta experiência.

\subsubsection{Alimentação inicial do sistema}

O sistema foi alimentado inicialmente através de bombeamento de esgoto da lagoa facultativa numa operação que durou duas horas, sendo esse processo executado logo após a conclusão dos dispositivos de entrada e saída de modo a permitir a imediata operação do sistema após a carga.

Medir a vazão de um efluente da lagoa de estabilização, com precisão, em baixas vazões, mostrou-se bastante complicado, pois as algas presentes, em alta concentração, são capazes de aderir a qualquer tipo de superfície, provocando interferência na medição. Foi necessária a pesquisa de um dispositivo que pudesse fornecer capacidade de regulagem de vazão e precisão na medição e que não estivesse sujeito à colmatagem provocada pelo alto teor de sólidos suspensos. Verificou-se que um instrumento de medição adequado era o hidrômetro taquímetro monojato visto que apresenta baixo custo de aquisição associado à boa precisão e não necessita de energia elétrica que não era disponível no local.

O equipamento instalado apresentava as seguintes características técnicas:

Vazão nominal: $3,0 \mathrm{~m}^{3} / \mathrm{h}$

Precisão : $\pm 2,0 \%$

Para a regulagem de vazão de esgoto, que chega ao sistema por gravidade através de tubo de PVC $\varnothing$ 3/4", foram testados vários dispositivos, conforme descrito a seguir.

O primeiro dispositivo se constituiu de um registro tipo gaveta em série com 
hidrômetro, sendo que este registro sofria estrangulamento até que se alcançasse a vazão desejada, que era obtida através da leitura do hidrômetro. Esta instalação não forneceu precisão adequada devido ao rápido depósito de materiais junto à sede do registro e conseqüente redução de vazão.

Outra tentativa constou de se colocar em série, com o hidrômetro, um tubo com pequenos furos que eram abertos até que alcançasse a vazão regulada. Este sistema apresentou melhor desempenho, mas houve depósito de materiais nos furos, prejudicando a medição. Neste método, percebia-se que mesmo enquanto os furos permaneciam limpos, havia queda de vazão devido à aderência de material junto às pás do hidrômetro, concluindo-se que este equipamento não era adequado para medição contínua do fluxo.

O sistema final adotado foi a instalação de hidrômetro paralelo ao sistema de regulagem de fluxo, sendo este equipamento somente utilizado para aferição da vazão através de fluxo intermitente do fluido pelo mesmo. A regulagem da vazão era realizada por meio de um tubo, com um rasgo na parte inferior que fica inserido no interior de um tubo de maior diâmetro.O deslocamento de um tubo sobre o outro permitia a regulagem da vazão afluente. Esta instalação mostrou-se bastante confiável, fornecendo valores de vazão dentro da precisão do equipamento de medição.

\subsection{Determinações analíticas}

\subsubsection{Análises laboratoriais}

As análises físico-químicas foram realizadas no laboratório de águas residuárias da Sabesp, em Lins, SP.

O monitoramento do sistema foi realizado conforme TABELA 3.5. 
TABELA 3.5 - Análises físico-químicas e bacteriológicas

\begin{tabular}{|c|c|c|c|}
\hline Parâmetros & $\begin{array}{c}\text { Método } \\
\text { APHA (1989) }\end{array}$ & Equipamentos & Marca \\
\hline $\mathrm{DBO}_{5}(\mathrm{mg} / \mathrm{l})$ & $5210 \mathrm{D}$ & $\begin{array}{l}\text { Incubadora } \mathrm{DBO}_{5} \\
\text { Bureta digital }\end{array}$ & $\begin{array}{l}\text { Tecnal } \\
\text { Brand }\end{array}$ \\
\hline DQO (mg/l) & $5220 \mathrm{~B}$ & $\begin{array}{c}\text { Digestor } \\
\text { Espectrofotômetro DR } \\
4000\end{array}$ & $\begin{array}{l}\mathrm{HACH} \\
\mathrm{HACH}\end{array}$ \\
\hline $\mathrm{pH}$ & $4500-\mathrm{H}+\mathrm{B}$ & pHmetro & Alpax \\
\hline Condutividade elétrica $(\mu \mathrm{s} / \mathrm{cm})$ & $2520 \mathrm{~B}$ & Condutivimetro mod. 850 & Orion \\
\hline Sólidos totais (mg/l) & $2540 \mathrm{~B}$ & Balança & $\begin{array}{l}\text { Nova } \\
\text { Ética }\end{array}$ \\
\hline Sólidos fixos (mg/l) & $2540 \mathrm{E}$ & - & - \\
\hline Sólidos voláteis (mg/l) & $2540 \mathrm{E}$ & Mufla & Quimis \\
\hline Sólidos Suspensos totais $(\mathrm{mg} / \mathrm{l})$ & $2540 \mathrm{D}$ & - & - \\
\hline Sólidos Suspensos fixos (mg/l) & $2540 \mathrm{E}$ & - & - \\
\hline $\begin{array}{l}\text { Sólidos Suspensos voláteis } \\
\text { (mg/l) }\end{array}$ & $2540 \mathrm{E}$ & Mufla & Quimis \\
\hline $\begin{array}{l}\text { Sólidos dissolvidos totais } \\
(\mathrm{mg} / \mathrm{l})\end{array}$ & ST - SST & - & - \\
\hline Sólidos dissolvidos fixos (mg/l) & SF - SSF & - & - \\
\hline $\begin{array}{l}\text { Sólidos dissolvidos voláteis } \\
\qquad(\mathrm{mg} / \mathrm{l})\end{array}$ & SV - SSV & - & - \\
\hline Nitrato (mg N/l) & $4500-\mathrm{NO}_{3}$ & $\begin{array}{l}\text { Coluna de redução de } \\
\text { Cádmio } \\
\text { Espectrofotômetro } \\
\text { DR4000 }\end{array}$ & $\begin{array}{l}\text { Nova } \\
\text { Ética } \\
\text { HACH }\end{array}$ \\
\hline Nitrito (mg N/l) & $4500-\mathrm{NO}_{2}$ & $\begin{array}{l}\text { Espectrofotômetro DR } \\
4000\end{array}$ & $\mathrm{HACH}$ \\
\hline Nitrogênio amoniacal (mg N/l) & $4500-\mathrm{NH}_{3} \mathrm{~F}$ & $\begin{array}{c}\text { Destilador } \\
\text { Espectrofotômetro DR } \\
4000\end{array}$ & $\begin{array}{l}\text { Tecnal } \\
\mathrm{HACH}\end{array}$ \\
\hline $\begin{array}{c}\text { Nitrogênio Total Kjeldahl (mg } \\
\mathrm{N} / \mathrm{l})\end{array}$ & $4500-\mathrm{N}_{\text {org }} \mathrm{B}$ & Digestor Destilador & $\begin{array}{r}\mathrm{HACH} \\
\text { Tecnal }\end{array}$ \\
\hline $\begin{array}{c}\text { Coliformes Totais (NMP / } \\
100 \mathrm{ml})\end{array}$ & $9223 \mathrm{~B}$ & $\begin{array}{c}\text { Seladora e Lâmpada UV } \\
\text { Incubadora }\end{array}$ & $\begin{array}{l}\text { Idexx } \\
\text { Quimis }\end{array}$ \\
\hline Escherichia coli (NMP/100 ml) & $9223 \mathrm{~B}$ & $\begin{array}{c}\text { Seladora e Lâmpada UV } \\
\text { Incubadora }\end{array}$ & Quimis \\
\hline
\end{tabular}

As amostras compostas foram coletadas uma vez por semana, durante 24 horas, e realizadas durante um período de sete semanas, começando pela segunda-feira na primeira semana, terça-feira na segunda semana e assim seqüencialmente até a sétima semana. As amostras foram compostas por alíquotas de igual volume coletadas a cada quatro horas. 


\subsubsection{Análises e determinações locais e de campo}

Compreendem as determinações realizadas por meio de equipamentos portáteis no campo e análises realizadas no laboratório da própria ETE (Estação de Tratamento de Esgoto.

Oxigênio dissolvido: determinado utilizando-se oxímetro portátil marca YSI modelo E550, sendo essa análise realizada diariamente em todo o período do experimento, em torno de 16 horas, diretamente na lagoa, em quatro posições. Superfície, $30 \mathrm{~cm}, 60 \mathrm{~cm}$ e $90 \mathrm{~cm}$ de profundidade.

Temperatura: utilizou-se, para determinação da temperatura, o sensor térmico acoplado ao oxímetro, sendo as leituras concomitantes com as de OD. 
Os resultados obtidos durante os experimentos I e II, que tiveram como finalidade verificar o comportamento da lagoa de maturação, utilizando macrófitas aquáticas são apresentados nas seções 4.1, 4.2 e 4.3.

\subsection{Metodologia operacional e analítica}

Os procedimentos operacionais adotados nesta pesquisa envolveram uma seqüência de investigações, procedimentos operacionais e metodologias analíticas, tal como se descreve a seguir.

\subsubsection{Introdução das espécies}

As plantas aquáticas, aguapé e lentilha d'água, foram coletadas no rio Tietê junto à barragem da Usina Hidroelétrica de Avanhandava, SP. A coleta se deu com a retirada das plantas por meio de rede e peneira, sendo aproveitada biomassa capaz de preencher aproximadamente $20 \%$ da área superficial da lagoa. No mesmo dia da coleta, as plantas foram introduzidas na lagoa.

\subsubsection{Tempo de detenção hidráulico}

Segundo VAN DER STEEN (1999), as macrófitas aquáticas possuem alta produtividade quando inseridas em sistemas com elevado teor de nutrientes, como é o 
caso de efluentes de lagoa de estabilização, aumentando sua biomassa rapidamente, o que exige manejo constante do sistema. Considerando esse rápido aumento de biomassa, fixou-se nesta pesquisa tempo de detenção hidráulico teórico de dois dias, de maneira a avaliar o desempenho do sistema com macrófitas aquáticas, dentro de parâmetros que o viabilizassem em escala real e permitissem o manejo manual da planta a baixo custo, sem a necessidade de utilizar mecanização.

Este tempo de detenção hidráulico levou em conta resultados satisfatórios obtidos por YAN (1986) que, a partir de tempo de detenção hidráulico entre 8 a 32 horas, conseguiu crescimento do aguapé dentro dos padrões estabelecidos na literatura.

\subsubsection{Rotinas operacionais}

A operação do sistema com a finalidade de obter os valores experimentais iniciou-se após o período de adaptação e se manteve por mais sete semanas, sendo realizadas diariamente no período da manhã e . os seguintes procedimentos operacionais

- Checagem da tubulação de alimentação da lagoa

- Aferição da vazão média tratada, limpeza e regulagem do dispositivo de regulagem de fluxo.

- Medição de OD e temperatura no afluente, efluente e na coluna d'água.

- Coleta de amostras do efluente compostas de acordo com o plano de coleta.

- Manejo da planta, correspondendo à colheita, pesagem, disposição da biomassa úmida.

- Pesagem e disposição final da biomassa seca (somente no período .).

- Verificação e contagem do número de insetos que eclodiram (ver 4.1.5).

\subsubsection{Manejo das plantas}

A maneira encontrada para determinação da produção das plantas aquáticas foi a setorização da lagoa, de acordo com a capacidade de crescimento de cada planta estudada (aguapé e lentilha d'água), de modo que se pudesse retirar de cada setor um volume de plantas correspondente à metade da biomassa existente. Seguiram-se os seguintes procedimentos operacionais na determinação da biomassa produzida: 
- Com a utilização de ancinho e peneiras, foi retirado volume de biomassa correspondente à aproximadamente metade da biomassa existente e realizada imediatamente a pesagem da biomassa. Determinado esse peso, o mesmo foi adotado como base para os demais quadros. Iniciava-se, então, a colheita, setor por setor, em dias consecutivos, sendo que, atingindo o último setor, verificavase visualmente se o primeiro estava totalmente coberto pela planta. $\mathrm{O}$ sistema de pesagem era composto por um cavalete de madeira, posicionado ao lado da lagoa, o qual suportava uma balança agrícola com capacidade de $70 \mathrm{~kg}$ e precisão de $0,1 \mathrm{~kg}$.

- Por tentativas, repetia-se esse ciclo, ajustando-se o volume retirado até que o mesmo correspondesse à capacidade de reprodução da planta. Determinava-se assim a capacidade de reprodução da planta, em peso.

- Ajustando-se à produção da biomassa, o ciclo foi repetido por três vezes.

- Após a pesagem, a biomassa foi colocada em uma tela metálica suportada por estrado de madeira à altura de um metro do solo para secagem natural.

- Decorrido o período de 24 horas, esta biomassa foi retirada da área de secagem e determinado o peso em estado seco.

Esta metodologia teve como enfoque estabelecer uma rotina operacional que pudesse ser utilizada em escala real com a possibilidade de manejo das plantas por trabalhadores rurais que se interessassem no uso da biomassa produzida.

\subsubsection{Determinação da presença de mosquitos}

Para determinação do número de mosquitos, que eclodiam na lagoa, e de maneira a obter um dado comparativo desse parâmetro entre a lagoa com aguapé e a lagoa com lentilha d'água, foram desenvolvidos dispositivo e metodologia própria para esse experimento. Este dispositivo era composto de um tubo de PVC de diâmetro de $100 \mathrm{~mm}$ e comprimento de $60 \mathrm{~cm}$ de altura, com um dos lados abertos e o outro fechado com tela plástica perfurada (tela mosqueteira).

Essas peças, em número de três, foram inseridas verticalmente em pontos distintos da lagoa experimental, sendo que o lado fechado com a tela metálica foi mantido a $10 \mathrm{~cm}$ de altura em relação à superfície da água. A cada 48 horas, contava-se o número de indivíduos que eclodiam, estabelecendo uma média no decorrer do 
experimento. Não houve preocupação em fechar a parte do tubo submersa porque as larvas se mantêm na superfície e não mergulham na profundidade correspondente à base do dispositivo.

\subsubsection{Sistema convencional comparativo}

Como o objetivo do trabalho era avaliar possibilidades de otimização de lagoas de estabilização a partir da utilização do aguapé e lentilha d'água, havia necessidade de comparar os resultados obtidos na lagoa experimental com um sistema convencional dentro das mesmas condições operacionais e ambientais. Para tanto, utilizou-se como testemunho a lagoa de estabilização terciária de Novo Horizonte que possui tempo de detenção hidráulico teórico de seis dias, volume $28.384 \mathrm{~m}^{3}$ e profundidade $1,20 \mathrm{~m}$. A comparação foi obtida por meio de coletas concomitantes na lagoa de maturação e lagoa com macrófitas. Assim, foi possível apontar quais as vantagens e desvantagens do sistema proposto: lagoa de estabilização com macrófitas aquáticas com tempo de detenção hidráulico de dois dias, profundidade $1,20 \mathrm{~m}$ e volume $46,8 \mathrm{~m}^{3}$ em relação à estação convencional.

\subsection{Aplicação do aguapé (Eichhornia Crassipes)}

\subsubsection{Revisão bibliográfica}

\subsubsection{Caracterização do aguapé}

De acordo com METCALF E EDDY (1999), o aguapé é uma planta flutuante que alcança até $0,9 \mathrm{~m}$ de altura, possui folhas redondas e brilhantes que são suportadas por um caule que fica acima da superfície da água doce. Encontra-se distribuída em todos os continentes, nas latitudes semitropicais e tropicais e em alguns países de clima temperado. Pertence à classe monocotiledônea, família Pontederiácea, ordem Pontederiales (FIGURA 4.1).

Morfologicamente, é constituído de um talo vertical chamado rizoma, do qual partem raízes e folhas. O rizoma flutua logo abaixo da superfície da água protegido por 
um certo número de folhas. A propagação do aguapé pode ser através de sementes ou de estalões.

O formato das folhas varia de oval a circular, medindo de 10 a 20 centímetros de diâmetro, possuindo bordas levemente curvadas e freqüentemente onduladas. As flores têm seis pétalas na cor azul purpurina com manchas amarelas no centro (STRANO, 1986).

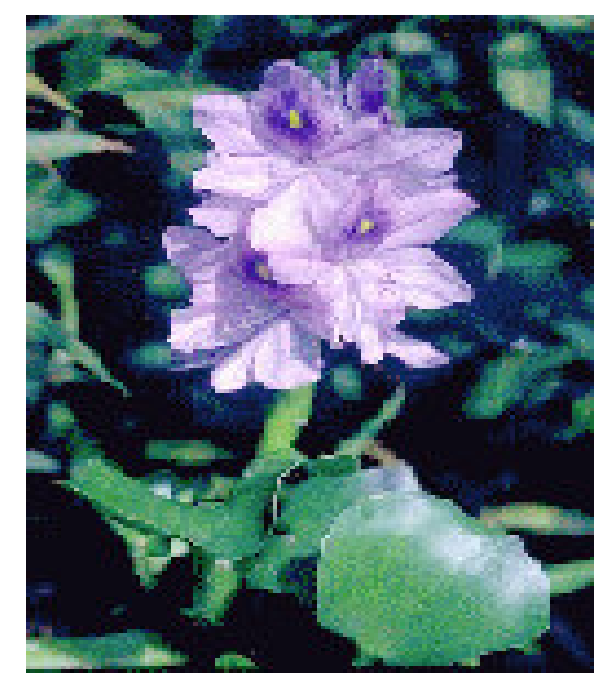

FIGURA 4.1 - Fotografia do aguapé detalhe da flor - Foto do autor

\subsubsection{Composição química e utilização do aguapé}

Vários pesquisadores, entre eles WOLVERTON E MC DONALD (1979); MITSUDA (1978) e STRANO (1986) analisaram a composição do aguapé de maneira a estabelecer as possibilidades de sua utilização como fonte de proteína vegetal na alimentação animal. A TABELA 4.1 ilustra um desses resultados.

TABELA 4.1 - Composição química do aguapé (folhas + pecíolos)

\begin{tabular}{c|c|c|c|c}
\hline $\begin{array}{c}\text { Matéria Seca } \\
(\%)\end{array}$ & $\begin{array}{c}\text { Proteína } \\
\text { Bruta (\%) a }\end{array}$ & Lipídeos (\%) a & Carboidrato (\%) a & $\begin{array}{c}\text { Cinza } \\
(\%) \mathrm{a}\end{array}$ \\
\hline 8,88 & 16,58 & 1,07 & 66,65 & 15,70 \\
\hline
\end{tabular}

a: porcentagem na matéria seca

Fonte: Adaptado de STRANO (1978) 
De acordo com LAREO E BRESSANI (1982), o aguapé tem sido estudado como alternativa de produção de biomassa na alimentação de animais, apresentando ótimos resultados de palatabilidade e digestibilidade de proteína.

WOLVERTON e MC DONALD (1979) usando esgoto doméstico estabeleceram experimentalmente que não são detectados níveis tóxicos de metais pesados, tais como prata e mercúrio, em análises do aguapé, o que possibilita o uso da planta na alimentação animal.

LUTZENBERGER (1985) afirma que o aguapé pode ser aplicado simplesmente como cobertura orgânica morta (mulching) em pomares, vinhedos, hortas, jardins e praças, sendo possível a sua compostagem artesanal associada a outras matérias primas facilmente disponíveis em pequenas propriedades rurais, tais como: folha de mandioca, palha de milho, palha de café, entre outros.

Segundo FREITAS (2000), o húmus produzido pelo aguapé pode ser utilizado como cobertura em pastagens na ordem de $500 \mathrm{~g} / \mathrm{m}^{2}$.

\subsubsection{Capacidade de depuração}

A ação depuradora do aguapé se deve à capacidade de absorção dos nutrientes pelas raízes e pela planta como um todo, além da utilização do esgoto realizado pelos organismos associados à rizosfera (PAGANINI, 1982).

Segundo THOMAS et al. (1987), o aguapé é capaz de controlar o crescimento das algas, evitando assim grandes quantidades deste microrganismo no efluente das lagoas de estabilização e melhorando o desempenho desses sistemas.

De acordo com METCALF E EDDY (1991), a expectativa de qualidade no efluente para sistemas aeróbios (não aerados) que utilizam aguapé é de: $\mathrm{DBO}_{5}(\mathrm{mg} / \mathrm{l})<$ 20; SS $(\mathrm{mg} / \mathrm{l})<20 ; \mathrm{NT}(\mathrm{mg} / \mathrm{l})<15$ e $\mathrm{P}_{\text {total }}(\mathrm{mg} / \mathrm{l})<10$ para tempo de detenção hidráulico entre 10 e 36 dias.

A literatura é escassa no que diz respeito a estudos sobre a utilização do aguapé em tratamento de esgoto doméstico, sendo mais comum referências sobre o comportamento do aguapé que se desenvolve naturalmente em lagos eutrofizados.

\subsubsection{Produtividade do aguapé}


Estimar a produtividade da macrófita aquática quando utilizada em sistemas de tratamento de esgoto é importante, pois há necessidade de manejo da planta, retirada da produção excedente e posterior disposição.

WOLVERTON E MC DONALD (1979) verificaram que o aguapé pode dobrar de peso em apenas 12 dias o que representa um crescimento médio de $8 \%$ ao dia, sendo que sua produtividade pode atingir de 360 a 480 ton/ha/ano de matéria seca com teor de proteína de $16,58 \%$ e matéria seca de $8,88 \%$.

LUTZENBERGER (1985) observou que enquanto na monocultura do eucalipto, em condições propícias, a produção de biomassa alcança 30 ton/ha/ano, o aguapé, em clima tropical e em água poluída, pode facilmente produzir entre 150 a 300 ton/ha/ano em base de matéria seca com uma vantagem adicional de que enquanto a colheita do eucalipto se faz aos sete ou oito anos, no aguapé, a colheita começa em dois ou três meses, sendo que o mesmo pode ser utilizado, por exemplo, para alimentação animal após compostagem.

Segundo GOMIDE et al. (1974), a produção de matéria seca do capim elefante (variedade mineira) é da ordem de 20 ton/ha/ano de matéria seca, sendo, portanto, a produção do aguapé acima de sete vezes maior do que de uma gramínea.

De acordo com ROCHA (1975) e GASI (1983), o número de aguapés, por metro quadrado, em um rio, chega a 118 plantas em média, sendo que estas plantas provocam o sombreamento do meio aquático, impedindo a formação de algas e outros tipos de vegetações submersas que são responsáveis pela introdução de oxigênio no meio aquático e, assim, prejudicam o ecossistema existente.

HAWAI et al. (1987) e COSSIO (1993) destacam que os projetistas devem considerar que, em condições climáticas tropicais ou semitropicais, o aguapé produz entre 200 a $250 \mathrm{~kg} / \mathrm{ha} /$ dia de peso seco, ou seja, quatro a cinco ton/ha/dia de plantas com 95\% de umidade. Portanto, devem ser previstas nos projetos das lagoas com aguapé formas que permitam a remoção de grande quantidade de plantas.

\subsubsection{Resultados experimentais}

\subsubsection{Determinação da biomassa produzida}

A maneira encontrada para determinar a produção do aguapé foi a setorização da 
lagoa em oito partes (FIGURA 4.2), tendo como base a literatura na qual inúmeras pesquisas relatam que a biomassa cresce $12,5 \%$ ao dia, dobrando em volume a cada oito dias (WOLVERTON E MC DONALD, 1979; GASI, 1983; COSSIO, 1993).

De acordo com método estabelecido no item 4.1.4, ao se iniciar a retirada da biomassa, a primeira tentativa resultou numa massa de $53 \mathrm{~kg}$, mas notou-se após oito dias que o primeiro setor não se encontrava totalmente adensado. Reduziu-se, então, para $48 \mathrm{~kg}$ por setor. Repetiu-se o ciclo e ainda assim percebeu-se que a densidade não era total após o ciclo completo. Reduziu-se, então, para $40 \mathrm{~kg}$ a retirada da biomassa por setor e realizaram-se três ciclos da retirada, confirmando assim esta massa como a produtividade do aguapé por setor (TABELA 4.2 e FIGURA 4.3).

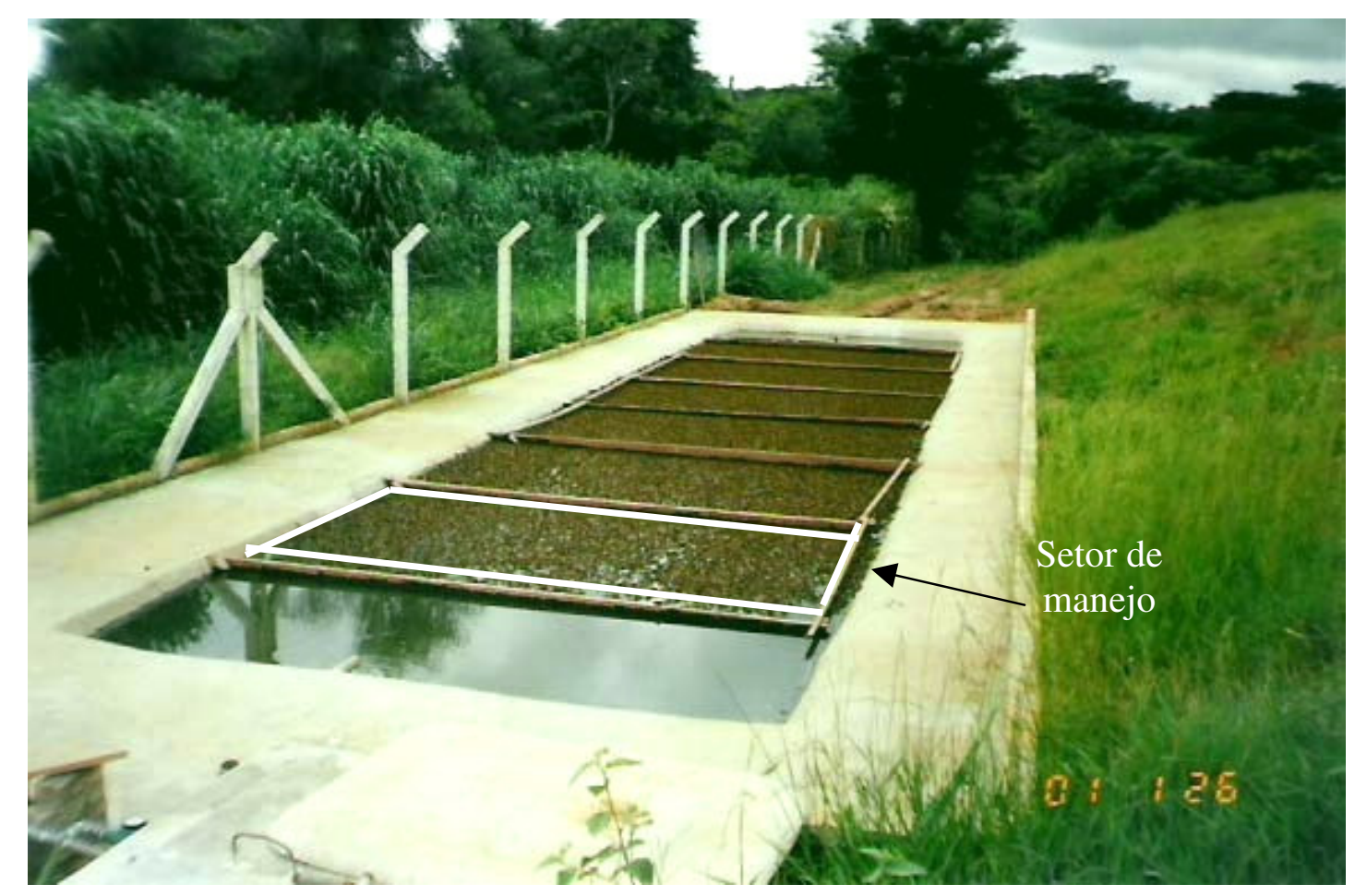

FIGURA 4.2 - Detalhe da setorização do canal para manejo do aguapé 
TABELA 4.2 - Produtividade do aguapé

\begin{tabular}{|c|c|c|c|c|c|}
\hline \multirow[t]{2}{*}{ Data } & \multirow[t]{2}{*}{ Compartimento } & \multirow{2}{*}{\begin{tabular}{|c|} 
Peso fresco \\
$(\mathrm{kg})$ \\
\end{tabular}} & \multirow{2}{*}{$\begin{array}{c}\text { Peso após secagem } \\
\mathrm{de} \\
01 \mathrm{dia} \\
(\mathrm{kg})\end{array}$} & \multicolumn{2}{|c|}{$\begin{array}{l}\text { Produtividade } \\
\left(\mathrm{kg} / \mathrm{m}^{2} / \mathrm{dia}\right)\end{array}$} \\
\hline & & & & fresco & seco \\
\hline $04 / 01 / 2001$ & 1 & 43 & 11 & 0,77 & 0,20 \\
\hline 05/01/2001 & 2 & 42 & 12 & 0,75 & 0,21 \\
\hline 06/01/2001 & 3 & 38 & 11 & 0,71 & 0,20 \\
\hline 07/01/2001 & 4 & 40 & 13 & 0,71 & 0,23 \\
\hline 08/01/2001 & 5 & 40 & 11 & 0,71 & 0,20 \\
\hline 09/01/2001 & 6 & 42 & 15 & 0,71 & 0,27 \\
\hline $10 / 01 / 2001$ & 7 & 41 & 12 & 0,71 & 0,21 \\
\hline $11 / 01 / 2001$ & 8 & 40 & 11 & 0,71 & 0,20 \\
\hline $12 / 01 / 2001$ & 1 & 39 & 11 & 0,71 & 0,20 \\
\hline $13 / 01 / 2001$ & 2 & 40 & 14 & 0,71 & 0,25 \\
\hline $14 / 01 / 2001$ & 3 & 40 & 11 & 0,71 & 0,20 \\
\hline $15 / 01 / 2001$ & 4 & 43 & 12 & 0,71 & 0,21 \\
\hline $16 / 01 / 2001$ & 5 & 39 & 11 & 0,71 & 0,20 \\
\hline $17 / 01 / 2001$ & 6 & 40 & 15 & 0,71 & 0,27 \\
\hline $18 / 01 / 2001$ & 7 & 40 & 15 & 0,71 & 0,27 \\
\hline 19/01/2001 & 8 & 40 & 12 & 0,71 & 0,21 \\
\hline 20/01/2001 & 1 & 38 & 14 & 0,71 & 0,25 \\
\hline 21/01/2001 & 2 & 40 & 11 & 0,71 & 0,20 \\
\hline $22 / 01 / 2001$ & 3 & 41 & 11 & 0,71 & 0,20 \\
\hline 23/01/2001 & 4 & 40 & 14 & 0,71 & 0,25 \\
\hline 24/01/2001 & 5 & 40 & 11 & 0,71 & 0,20 \\
\hline 25/01/2001 & 6 & 42 & 12 & 0,71 & 0,21 \\
\hline 26/01/2001 & 7 & 39 & 12 & 0,71 & 0,21 \\
\hline 27/01/2001 & 8 & 38 & 13 & 0,71 & 0,23 \\
\hline média & & 40 & 12,29 & 0,72 & 0,22 \\
\hline
\end{tabular}


Para tempo de detenção hidráulico teórico do esgoto na lagoa de 48 horas, a conclusão foi de uma produção média de $0,72 \mathrm{~kg} / \mathrm{m}^{2} /$ dia de peso fresco que corresponde a 2.592 ton/ha/ano (7,2 ton/ha/dia) de peso úmido, produtividade maior que a encontrada na literatura já citada, que fica entre 4 a 5 ton/ha/dia.

Não foi feita a secagem em estufa, pois esta pesquisa visa a aplicabilidade do aguapé a custo reduzido e com fácil acessibilidade na técnica. O método utilizado para secagem foi em grade suspensa pelo período de um dia. Notou-se uma redução brusca, na ordem de $70 \%$, da biomassa por perda da água devido principalmente à separação da água retida nas raízes após a colocação na grade suspensa. A produtividade do aguapé com a secagem ao sol resultou em $0,22 \mathrm{~kg} / \mathrm{m}^{2} / \mathrm{dia}$, correspondendo a 792 ton/ha/ano.

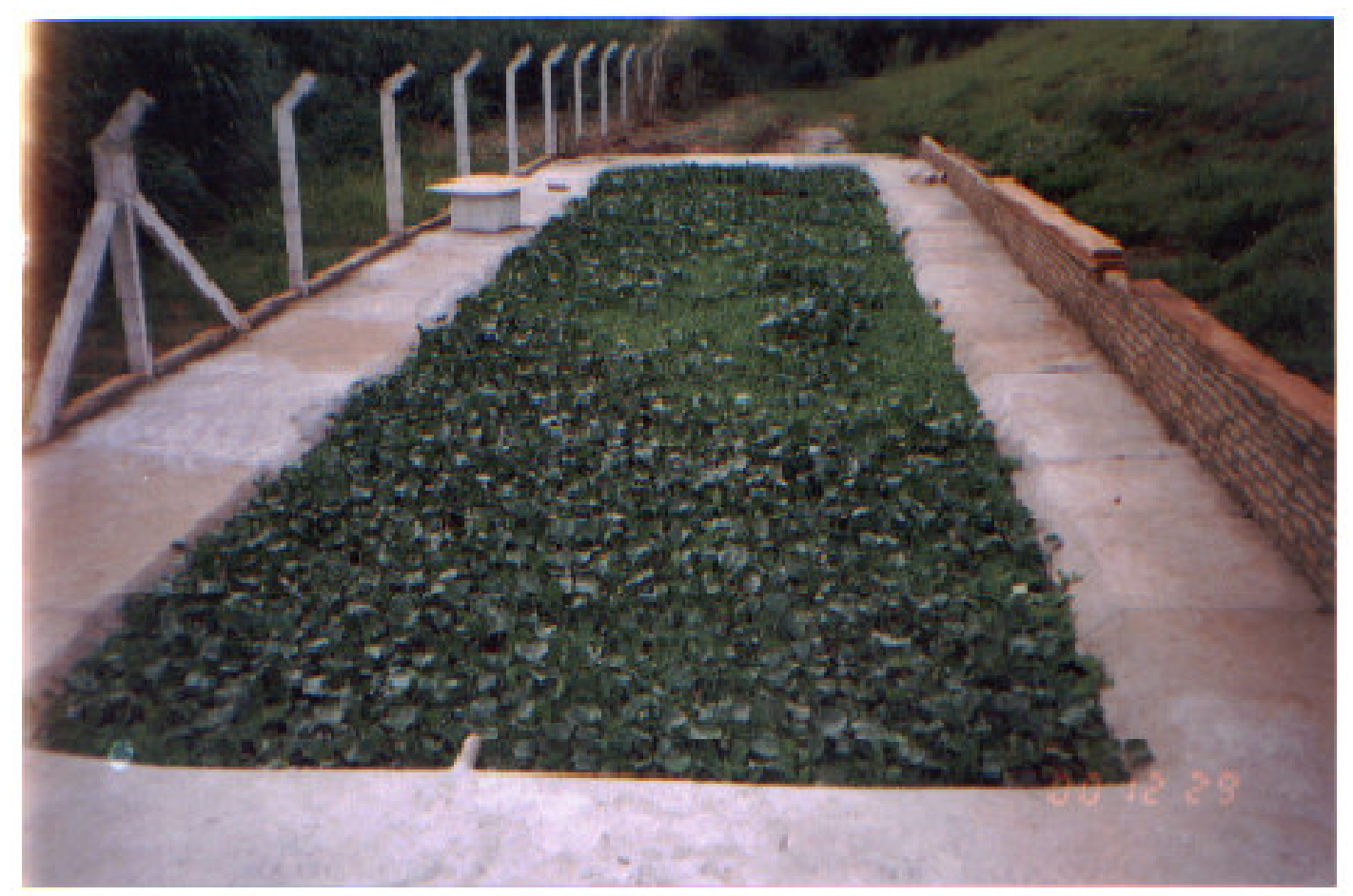

FIGURA 4.3 - Aguapé em fase produtiva

\subsubsection{Taxa de aplicação superficial e carregamento orgânico para aplicação de aguapé no tratamento de esgoto}

Segundo METCALF E EDDY (1991), as taxas de aplicação superficial e carregamento orgânico, quando se utilizam macrófitas em lagoas de tratamento de esgoto, devem ser respectivamente no máximo de $0,06 \mathrm{~m}^{3} / \mathrm{m}^{2} / \mathrm{dia}$ e de $90 \mathrm{~kg}$ $\mathrm{DBO}_{5} /$ ha/dia.

Tendo em vista a busca de manejo simples da biomassa, como citado anteriormente, levou-se em conta no dimensionamento do sistema somente o tempo de 
detenção hidráulico. Portanto, estas taxas não foram utilizadas. As taxas de operação da lagoa experimental eram bastante superiores ao descrito por esses autores, sendo empregada a taxa de aplicação superficial de $0,375 \mathrm{~m}^{3} / \mathrm{m}^{2} /$ dia e taxa de carregamento orgânico de $168 \mathrm{~kg} \mathrm{DBO} /$ /ha/dia.

Não foi encontrada outra referência bibliográfica que apontasse detalhes de projeto para construção de sistemas de tratamento de esgoto doméstico, utilizando aguapé.

\subsubsection{Aceitabilidade do aguapé por animais}

Com a finalidade de verificar a aceitabilidade do aguapé por ovinos e bovinos, manteve-se um animal adulto de cada uma dessas espécies em local isolado por 24 horas e, nesse período, não lhe foi fornecida ração. Prepararam-se quatro tipos de compostos que foram colocados à disposição dos animais por um período de seis horas conforme descrito abaixo:

$1^{\circ}$ tipo: Aguapé em estado fresco, sem raízes e sem mistura de ração.

$2^{\circ}$ tipo: Idem acima com adição de $50 \%$ de farelo de soja.

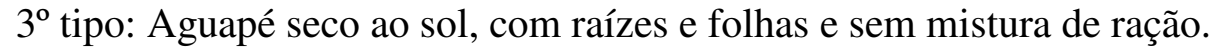

$4^{\circ}$ tipo: Idem acima com adição de $50 \%$ de farelo de soja.

Os animais, durante este período de seis horas, não tocaram na ração, permanecendo ambos em estado de jejum.

Não se pode concluir que há inviabilidade de utilização do aguapé na alimentação de animais, mas que essa utilização não é possível retirando simplesmente o aguapé do sistema e oferecendo diretamente aos animais.

Verificou-se que o sistema produz grande quantidade de biomassa de difícil utilização por pequenos produtores agrícolas com aplicação de técnicas simples e que a disposição inadequada do aguapé poderá ocasionar problemas típicos na disposição de resíduos sólidos, tais como: geração de chorume, proliferação de insetos e mosquitos e infestação de cursos d'água, dificultando a utilização da planta.

\subsubsection{Presença de insetos}

Notou-se, no decorrer do experimento, que a lagoa coberta pelo aguapé mostrou- 
se um grande foco de mosquitos, atingindo alta infestação após 60 dias de operação.

A partir de observações visuais da lagoa verificou-se que os seguintes fatores favorecem esta infestação:

- O aguapé impedia a ação de ventos e a formação de marolas, facilitando o pouso do mosquito sobre a lâmina d'água.

- O sistema, por ser confinado, não possuía predadores naturais.

- Não havia arraste das larvas para o efluente, pois as mesmas ficavam atracadas às plantas.

- As folhas, por não ficarem em contato com a superfície da água, não ofereciam obstáculo para respiração das larvas.

O principal tipo de mosquito observado foi o mosquito doméstico do gênero Culex que vive predominantemente em regiões urbanas e cujas larvas crescem em águas paradas. Segundo informações obtidas no site http://www.pragas.terra.com.br , estas larvas são sempre encontradas na água e não possuem pernas nem asas e, apesar de serem aquáticas, as larvas respiram sempre o oxigênio do ar, necessitando chegar à superfície da água. Possuem uma estrutura chamada sifão respiratório que as permite retirar o oxigênio do ar. Este sifão, no caso do gênero Culex, fica perpendicular à superfície, o que o distingue de outras espécies, permitindo a sua identificação.

As larvas eclodem 30 a 40 horas após a postura dos ovos, em condições adequadas.

Os resultados da TABELA 4.3 demostram o grau de infestação da lagoa (amostras coletadas conforme item 4.1.5).

TABELA 4.3 - Número de espécies que eclodiram no tubo de amostragem da lagoa com aguapé

\begin{tabular}{cccc}
\hline Amostra & Tempo (h) & $\begin{array}{c}\mathrm{N}^{\circ} \text { indivíduos que } \\
\text { eclodiram }\end{array}$ & Área $\left(\mathrm{cm}^{2}\right)$ \\
\hline 1 & 48 & 20 & 78,5 \\
2 & 48 & 18 & 78,5 \\
3 & 48 & 25 & 78,5 \\
\hline
\end{tabular}

Percebeu-se ainda que os mosquitos adultos não habitavam junto à lagoa. A presença destes só era notada ao entardecer, quando uma nuvem de insetos pairava sob 
o sistema, efetuando a desova.

De acordo com METCALF E EDDY (1991), algumas estratégias podem ser utilizadas para controle da população de mosquitos:

- Redução da carga orgânica no sistema;

- introdução de espécie de peixe que seja predador natural do mosquito;

- aumento da freqüência da retirada das plantas;

- aplicação de spray de água durante o entardecer;

- aplicação de agentes químicos de controle (larvicidas).

TENNESSEN (1993) aponta as mesmas estratégias, mas conclui que, devido às grandes áreas superficiais, a aplicação de qualquer método de controle de mosquitos em lagoas de tratamento apresenta pouca eficácia e requer muito trabalho e custos elevados.

Concluiu-se que a proliferação de mosquitos provocada pelo aguapé inviabiliza, por si só, a utilização dessa macrófita no tratamento de esgotos domésticos, pois essa infestação atingiria rapidamente a população circunvizinha da lagoa de tratamento, com riscos à saúde e desconforto da população.

\subsubsection{Interpretação das análises físico-químicas e bacteriológicas}

Realizou-se um total de sete coletas no afluente e efluente da lagoa com aguapé e da lagoa de maturação ( amostras coletadas conforme item 3.6.1). Os resultados são apresentados pela TABELA 4.4 e Apêndices A, B, C. 
TABELA 4.4 - Resultados de análises físico-químicas e bacteriológicas do esgoto afluente e efluente da lagoa de maturação do sistema da Sabesp com TDH = 6 dias e da lagoa piloto com aguapé com $\mathrm{TDH}=2$ dias (valores médios de 07 coletas)

\begin{tabular}{|c|c|c|c|c|c|c|}
\hline \multirow[b]{3}{*}{ Parâmetro } & \multirow[b]{3}{*}{ Un } & \multirow{2}{*}{\multicolumn{3}{|c|}{$\frac{\text { Concentração }}{\text { Pontos de coleta }}$}} & \multirow{2}{*}{\multicolumn{2}{|c|}{ Variação (\%) }} \\
\hline & & & & & & \\
\hline & & afluente & $\begin{array}{l}\text { Lagoa de } \\
\text { maturação- } \\
\text { Efluente }\end{array}$ & $\begin{array}{l}\text { Lagoa com } \\
\text { aguapé- } \\
\text { Efluente }\end{array}$ & $\begin{array}{c}\text { Lagoa de } \\
\text { maturação }\end{array}$ & $\begin{array}{c}\text { Lagoa } \\
\text { com } \\
\text { aguapé }\end{array}$ \\
\hline Oxigênio Dissolvido & $(\mathrm{mg} / \mathrm{l})$ & 7,8 & 6,9 & 1,2 & $-11,5$ & $-84,6$ \\
\hline Sólidos Totais & $(\mathrm{mg} / \mathrm{l})$ & 523 & 486 & 509 & $-7,1$ & $-2,7$ \\
\hline Sólidos Totais Fixos & $(\mathrm{mg} / \mathrm{l})$ & 271 & 267 & 271 & $-1,5$ & 0,0 \\
\hline Sólidos Totais Voláteis & $(\mathrm{mg} / \mathrm{l})$ & 252 & 219 & 238 & $-13,1$ & $-5,6$ \\
\hline Sólidos Suspensos & $(\mathrm{mg} / \mathrm{l})$ & 97 & 57 & 80 & $-41,2$ & $-17,5$ \\
\hline Sólidos Suspensos Fixos & $(\mathrm{mg} / \mathrm{l})$ & 8 & 2 & 6 & -75 & -25 \\
\hline $\begin{array}{c}\text { Sólidos Suspensos } \\
\text { Voláteis }\end{array}$ & $(\mathrm{mg} / \mathrm{l})$ & 89 & 55 & 74 & $-38,2$ & $-16,9$ \\
\hline DQO & $(\mathrm{mg} / \mathrm{l})$ & 200 & 190 & 140 & $-5,0$ & $-30,0$ \\
\hline $\mathrm{DBO}_{5}$ & $(\mathrm{mg} / \mathrm{l})$ & 80 & 85 & 68 & 6,3 & -15 \\
\hline Fósforo Total & $(\mathrm{mg} / \mathrm{l})$ & 4,3 & 6,5 & 6,4 & 51,2 & 48,8 \\
\hline Condutividade & $\mathrm{dS} / \mathrm{m}$ & 845 & 830 & 847 & $-1,8$ & 0,2 \\
\hline Coliformes Totais & NMP & $7,95 \cdot 10^{6}$ & $2,00 \cdot 10^{6}$ & $2,10 \cdot 10^{6}$ & $-74,8$ & $-73,6$ \\
\hline Coliformes Fecais & NMP & $3,60 \cdot 10^{5}$ & $3,50 \cdot 10^{4}$ & $1,20.10^{3}$ & $-90,3$ & $-99,7$ \\
\hline Nitrogênio Total Kjedhal & $(\mathrm{mg} / \mathrm{l})$ & 37,8 & 31,36 & 26,8 & $-17,0$ & $-29,1$ \\
\hline Nitrogênio Amoniacal & $(\mathrm{mg} / \mathrm{l})$ & 31,5 & 27,16 & 25,48 & $-13,8$ & $-19,1$ \\
\hline Nitrato $\left(\mathrm{NO}_{3}\right)$ & $(\mathrm{mg} / \mathrm{l})$ & 0,3 & 0,7 & 0,5 & 133 & 66,7 \\
\hline
\end{tabular}

- Condutividade elétrica

Segundo STRANO (1986), as macrófitas aquáticas, no caso o aguapé, devido à 
sua constituição com aproximadamente $90 \%$ de água, e à sua forma que proporciona um aumento da superfície da interface água-ar, são responsáveis por um aumento entre 50\% e 300\% na quantidade de água evaporada, comparada com uma lagoa sem aguapé.

De acordo com UEHARA E VIDAL (1989), teoricamente, a evaporação intensa da água de uma lagoa de estabilização pode produzir aumento da salinidade com efeitos prejudiciais aos microrganismos e ao equilíbrio biológico, mas consideram que os dados disponíveis no Brasil demonstram que a influência da evaporação pode ser considerada desprezível.

Esperava-se, portanto, um aumento da salinidade na lagoa com aguapé provocada pela perda de água para a planta e para o meio ambiente, mas nesta experiência, percebeu-se um aumento pouco significativo, de $0,2 \%$ na condutividade elétrica, indicando pouca variação na concentração de sais no efluente. Nas lagoas de maturação, devido à alta taxa de evaporação, baixa profundidade e grande superfície, é natural que ocorra também um aumento de salinidade. As análises do efluente deste sistema constataram redução na condutividade de $1,8 \%$.

Há indicações de que ocorreram efeitos compensatórios que acabaram por determinar taxas semelhantes de evaporação entre os dois sistemas, ou seja, apesar do aguapé aumentar a superfície de evaporação, a planta reduz a ação do vento e a temperatura da superfície da lagoa. Em contrapartida, a lagoa de maturação por ter a superfície livre está sujeita à alta intensidade de ventos e elevada temperatura superficial.

- Demanda Química de Oxigênio (DQO)

A DQO do efluente da lagoa com aguapé era em média $30 \%$ menor que a do afluente. Portanto, houve redução de matéria orgânica. Já a redução na lagoa de maturação (controle) alcançou 5,0\%, sendo pouco significativa, o que mostra baixa eficiência deste sistema. Deve-se ressaltar que a lagoa de maturação foi projetada para redução de patógenos e não para redução de carga orgânica.

Apesar de se manter o tempo de detenção hidráulico teórico de dois dias, na lagoa com aguapé, bastante inferior ao da lagoa de maturação com TDH de seis dias, a lagoa com aguapé demonstrou maior eficiência na remoção de carga orgânica.

- Sólidos Totais 
A concentração de sólidos totais se manteve pouco alterada, com pequena variação em relação ao efluente em ambos os sistemas estudados: lagoa de maturação e lagoa com aguapé.

No caso da lagoa com aguapé, a redução média encontrada foi de 7,5\%, contra um valor médio da lagoa em $5,7 \%$.

Observou-se, em algumas amostras do efluente da lagoa experimental, um aumento significativo na concentração de sólidos, concluindo-se que este fato se deve ao desprendimento de material resultante do manejo constante do aguapé, que permanece em suspensão, atingindo o efluente.

\section{- Sólidos Suspensos Voláteis (SSV)}

De acordo com VON SPERLING (1996), em lagoas facultativas é normal ocorrer um incremento na concentração de SSV devido ao aumento de algas que são sintetizadas a partir da luz solar e nutrientes orgânicos presentes na massa líquida.

Houve redução de SSV no efluente da lagoa de maturação em estudo na ordem de $38,2 \%$, provocada principalmente pela posição do tubo coletor efluente que fica a 30 $\mathrm{cm}$ de profundidade.

No caso da lagoa com aguapé, que apresentava oxigênio dissolvido próximo a zero na massa líquida, ocorreu redução de algas, o que foi visível pela coloração apresentada, com uma redução da concentração de SSV de 16,9 \%. É nítido, neste caso, que estes materiais em suspensão estavam muito mais ligados à ressuspensão dos sólidos provocada pelo manejo do aguapé do que com a presença de algas.

\section{- Turbidez}

Verificou-se, a partir da análise visual das amostras, menor quantidade de algas no efluente da lagoa com aguapé, demonstrando que esta planta, devido ao sombreamento que provoca na superfície líquida, por meio de suas folhas, impede a sobrevivência e proliferação de algas.

Com o objetivo de verificar o resultado da redução das algas no efluente final, provocada por sombreamento que, segundo MARIA DO CARMO CALLIJURI $(2001)^{4}$,

\footnotetext{
4 MARIA DO CARMO CALLIJURI - Informação pessoal obtida no Departamento de Hidráulica e Saneamento da EESC-USP 03/2001.
} 
pode ocorrer em períodos relativamente curtos, em torno de 24 horas, fato confirmado por SILVA E MARA (1979) que verificaram que com a ausência de ventos as algas não motoras sedimentam e por não realizarem fotossíntese morrem e são decompostas, realizou-se o seguinte experimento:

- Coletaram-se três amostras de $1000 \mathrm{ml}$, em períodos distintos, do efluente da lagoa de maturação e da lagoa com aguapé. As amostras foram mantidas em um Becker no interior de uma caixa sem que houvesse penetração de luz. Encontrou-se, a partir de coletas do líquido superficial, os resultados apresentados na TABELA 4.5 .

TABELA 4.5 - Resultados de análise de turbidez do afluente e efluente da lagoa de maturação e lagoa com aguapé

\begin{tabular}{l|c|c|cc}
\hline \multicolumn{2}{c}{ Análise de Turbidez } & \multicolumn{3}{c}{ Tempo (horas) } \\
\cline { 3 - 5 } & Local & 0 & 24 & 48 \\
\hline Data da coleta & Afluente & 51 & \multicolumn{3}{c}{ Turbidez (NTU) } \\
\hline \multirow{2}{*}{$30 / 01 / 2001$} & Lagoa aguapé & 18 & 10 & 24 \\
& Lagoa maturação & 21 & 14 & 12 \\
& Afluente & 52 & 24 & 18 \\
$02 / 02 / 2001$ & Lagoa aguapé & 18 & 10 & 7 \\
& Lagoa maturação & 22 & 16 & 12 \\
& Afluente & 49 & 25 & 18 \\
$09 / 02 / 2001$ & Lagoa aguapé & 23 & 17 & 17 \\
& Lagoa maturação & 22 & 17 & 14 \\
\hline
\end{tabular}

Conclui-se que ocorre uma queda brusca na turbidez após 24 horas sem a presença de iluminação, indicando melhoria na qualidade do efluente no que diz respeito a sólidos em suspensão e matéria orgânica constituída por algas.

ANDRADE (2000), ao estudar o comportamento de lagoas de maturação com cobertura plástica, verificou que os valores de $\mathrm{DBO}_{5}$ e DQO eram menores em lagoas cobertas com plásticos do que em uma lagoa de controle sem cobertura, devido à redução da concentração de algas no efluente.

HANCOCK E BUDDHAVARAPU (1993) apontam que a eliminação de luz na 
lagoa provocada por cobertura vegetal ou plástica resulta na morte das algas e maior eficiência na remoção de $\mathrm{DBO}_{5}$.

Sendo assim, recomenda-se que sejam estudados sistemas afóticos como métodos de retenção de algas, pois na ausência de luz, as algas morrem, sedimentam e são decompostas anaerobiamente no fundo do sistema.

- Fósforo

A determinação deste parâmetro nas amostras do afluente, efluente da lagoa com aguapé e efluente da lagoa de maturação mostrou que a concentração média de fósforo total foi respectivamente 4,3 mg/l, 6,4 mg/l e 6,5 mg/l. Houve, portanto, incremento de fósforo total tanto na lagoa de maturação quanto na lagoa com aguapé.

Um fator importante a ser considerado é que o esgoto afluente aos sistemas estudados vinha da lagoa secundária que possuía tubo coletor de saída, posicionado junto à superfície e, portanto, recebia pouca influência da ressuspensão do fósforo contida no sedimento, o que resultou em baixa concentração de fósforo na entrada das lagoas com aguapé e maturação.

HORTEGAL (1992), ao realizar experimentos nas lagoas de estabilização de Maracanaú, CE verificou também que as maiores remoções de fósforo ocorriam nas amostras colhidas na superfície da lagoa quando comparadas com amostras da coluna d'água, com resultados de 32,8\% e 11,5\% de remoção de fósforo total nas amostras de superfície e coluna d'água, respectivamente.

Na lagoa de maturação, houve aumento da concentração de fósforo de 51,2\% que pode estar associado à posição do tubo coletor do efluente que fica a $30 \mathrm{~cm}$ de profundidade e assim resgata fósforo do sedimento pelo efeito de turbilhonamento .

MARA et al. (1992) consideram que a eficiência de remoção de fósforo depende de fatores que são a quantidade de fósforo que fica retido no sistema por precipitação ou sedimentação em relação à quantidade que é retomada por mineralização ou ressolubilização e que existe no sedimento grande quantidade de material em decomposição que é responsável pela liberação de fósforo para a coluna líquida.

No caso da lagoa com aguapé, o aumento da concentração de fósforo, mesmo com elevado crescimento da biomassa e conseqüente maior utilização de nutrientes, esteve associado ao manejo do aguapé que promoveu agitação da massa líquida e 
resgatou o fósforo do sedimento, somado ao aporte de fósforo orgânico devido à morte e decomposição de algas que estão presentes em alta concentração no afluente, provocada pelo sombreamento do aguapé sobre a lagoa.

- Nitrogênio

Ocorreu maior redução de nitrogênio amoniacal na lagoa com aguapé quando comparado com a lagoa de maturação devido à incorporação deste nutriente na biomassa da planta. Quando se comparam os dois processos, lagoa de maturação e lagoa com aguapé, a lagoa de maturação para um tempo de detenção hidráulico de seis dias, promoveu redução de 13,8\% de nitrogênio amoniacal, enquanto a lagoa de aguapé, para um tempo de detenção hidráulico de dois dias, alcançou $19,1 \%$ de redução.

A presença de pequena concentração de nitrato nos dois sistemas demonstrou pouca capacidade de nitrificação dos mesmos.

KIM e KIM (2000) encontraram relação semelhante em experimento realizado em Ansan City, Coréia do Sul no qual uma lagoa com aguapé apresentou eficiência na remoção de nitrogênio de 57,3\% enquanto para o mesmo sistema uma lagoa secundária apresentou remoção 49,5\%, apesar de a lagoa secundária apresentar tempo de detenção hidráulico três vezes maior que a lagoa com aguapé.

\subsection{Aplicação da lentilha d'água (Lemna minor)}

\subsubsection{Revisão bibliográfica}

\subsubsection{Caracterização da lentilha d'água}

De acordo com POTT \& CERVI (1999), a lentilha d'água é uma planta diminuta, sem diferenciação de caule, e reduzida a um pequeno corpo que é chamado de fronde. Ficam flutuantes e livres na superfície, possuem folhas simétricas verdes, agrupando-se em frondes de dois a dez ou mais e também podem se apresentar solitárias. Pertencem à classe Monocotiledônea, família Lemnácea, gênero Lemna, espécie Lemna Minor (ver FIGURA 4.4).

O nome comum utilizado no Brasil é "lentilha d'água" e o utilizado em 
literaturas estrangeiras é "Duckweed".

A família lentilha d'água é encontrada em todo o mundo, exceto nas regiões áridas, possuindo como centro de dispersão a América do Sul.

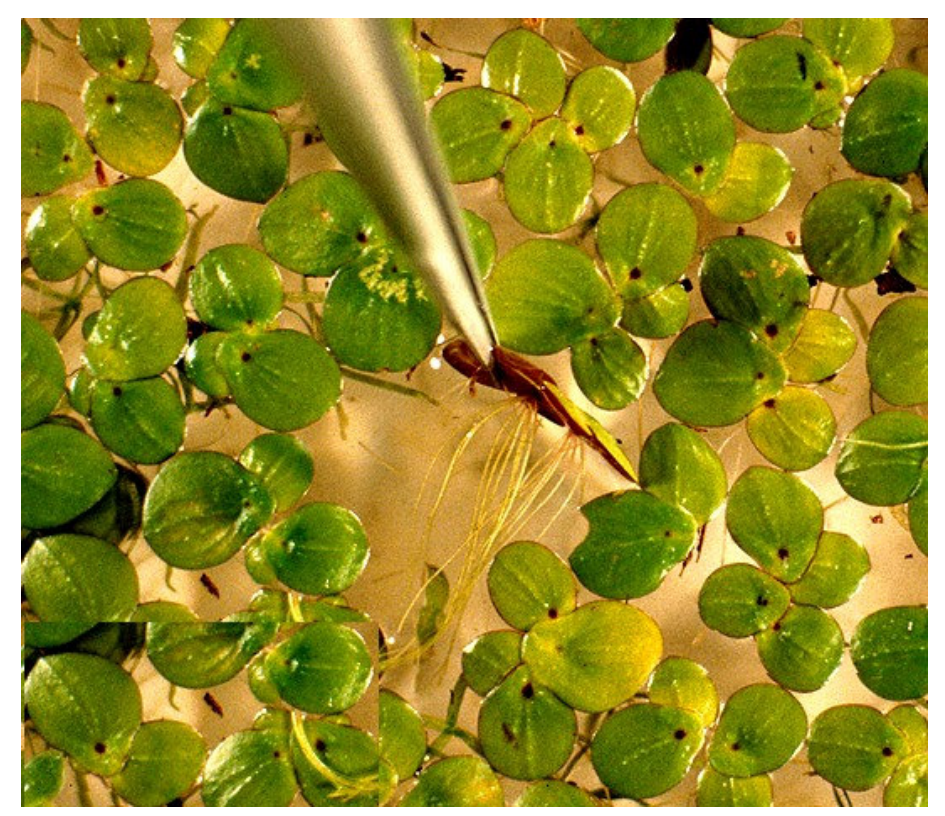

FIGURA 4.4 - Lentilha d'água - Foto do autor

\subsubsection{Utilização da lentilha d'água em sistemas naturais de tratamento}

Segundo CHAIPRATAT et al. (2003), a principal função da lentilha d'água em sistemas de tratamento secundário de esgotos é a recuperação de nutrientes, mas deve-se considerar que a lentilha d'água, por cobrir densamente a superfície da água, inibe a entrada de oxigênio na massa líquida, tanto por difusão quanto pela produção de fitoplâncton, necessitando de sistemas de pós-aeração.

De acordo com HANCOCK E BUDDAVARAPU (1993), quando se tem limite restrito para lançamento de efluentes, os sistemas de lagoas de estabilização em série não são capazes de atingir o desempenho necessário, necessitando de pós-tratamento, sendo que esse baixo desempenho ocorre principalmente devido à elevada presença de algas. Assim, estes autores concluem que o tratamento terciário, empregando a lentilha d'água, ao impedir a penetração de luz, provoca a morte das algas, melhorando o desempenho dos sistemas.

Em ambiente com elevada concentração de nutrientes, como é o caso de lagoas de estabilização, a lentilha d'água se reproduz rapidamente, cobrindo grandes áreas em 
poucos dias. Essa cobertura superficial provocada pela planta resulta em uma barreira física que impede a penetração de luz. O sistema se torna anaeróbio e, nessas condições, as algas morrem e se decompõem no fundo da lagoa. (VAN DER STEEN, 1999).

As reações físico-químicas e biológicas que ocorrem numa lagoa com lentilha d'água estão representadas na FIGURA 4.5.

\section{Lentilha d'água}

1. Previne a penetração da luz

2. Controle de mosquito

3. Elimina Aerossóis, Odores

1. SST

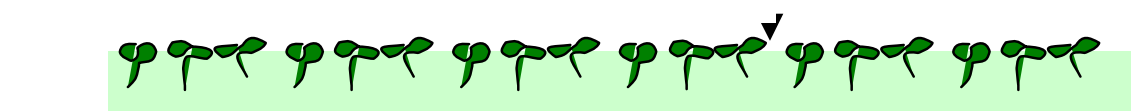

5-10 cm zona aeróbia

1. Respiração de

Raízes

2. Oxidação de $\mathrm{H}_{2} \mathrm{~S}$

2. $\mathrm{DBO}_{5}$

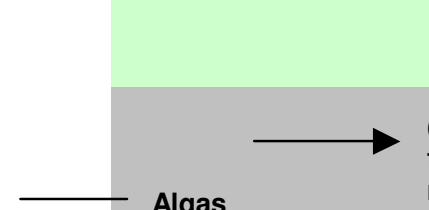

(Nenhuma

fotossíntese)

morte de algas

liberação de

nutrientes

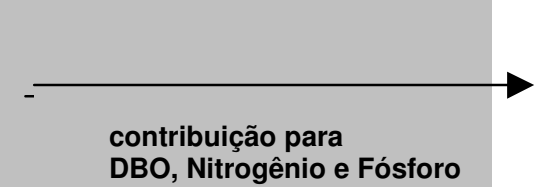

Zona Anoxica

SST $<10 \mathrm{MG} / \mathrm{L}$

DBO, Nitrogênio e Fósforo

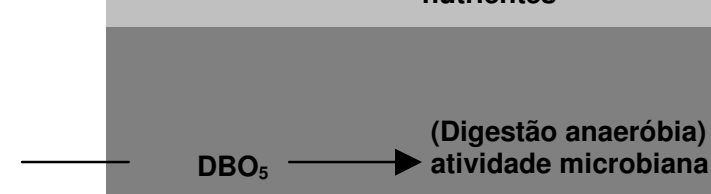

atividacle
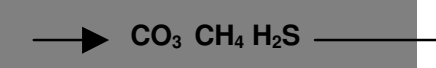

$\mathrm{DBO}_{5}<10 \mathrm{mg} / \mathrm{l}$

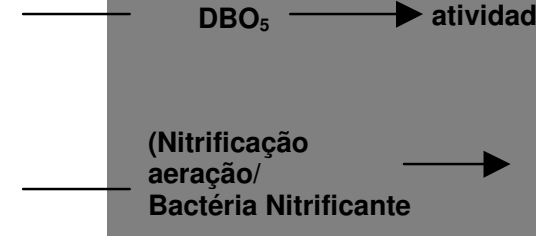

(Desnitrificação/

Bioacumulação)

Bactéria

3. Nitrogênio

Bactéria Nitrificante

$\mathrm{NO}_{3}$

Desnitrificante

por cima do solo

Zona Anaeróbia

absorção pela lentilha d'agua absorçaõ pelas bactérias

4. Fósforo

$\mathrm{T}(\mathrm{P})$ Adsorsão/Precipitação em Partículas de Solo

AFLUENTE

EFLUENTE

FIGURA 4.5 - Reações físico-químicas e biológicas que ocorrem em uma lagoa de estabilização com lentilha d'água. Fonte: adaptado de HANCOCK E BUDDAVARAPU (1993)

De acordo com VAN DER STEEN (1999), a baixa eficiência de lagoas de estabilização na remoção de $\mathrm{SST}$ e $\mathrm{DBO}_{5}$, que ocorre devido à presença de grande quantidade de algas no efluente, pode ser melhorada com a utilização da lentilha d'água que impede a penetração de luz, causando a morte, sedimentação e decomposição das 
algas, melhorando a qualidade do efluente.

\subsubsection{Produtividade}

Segundo PYCHA (1992), a lentilha d'água se reproduz rapidamente e dobra em número de frondes (folhas) entre dois a quatro dias e ainda segundo HANCOCK E BUDDAVARAPU (1993), em condições ideais (alta concentração de nutrientes, elevada luminosidade e temperatura), a lentilha d'água pode dobrar em massa em três a quatro dias e cobrir completamente a superfície da água.

Em experimento realizado por VAN DER STEEN (1998) em uma lagoa experimental da cidade de Negev Desert, Israel, verificou-se que a cada cinco dias a biomassa da lentilha d'água dobrava de volume, ou seja, mantendo-se a freqüência de retirada de $50 \%$ da biomassa de cinco em cinco dias o sistema mantinha a mesma densidade de matéria.

\subsubsection{Resultados experimentais}

\subsubsection{Determinação da biomassa produzida}

O método para determinação da biomassa produzida foi o mesmo utilizado na determinação da biomassa do aguapé descrito no item 4.1.4 deste trabalho, sendo que para a setorização da lagoa, essa foi dividida em quatro partes. Essa divisão decorre de resultados encontrados na literatura que indicam que a biomassa aumenta em $25 \%$ ao dia, dobrando em volume a cada quatro dias. (PYCHA, 1992; CHAIPRATAT et al., 2003)

A conclusão foi de uma produção média de $0,14 \mathrm{~kg} / \mathrm{m}^{2} /$ dia e de peso fresco correspondente a 504 ton/ha/ano (TABELA 4.6 e FIGURA 4.6).

A redução de biomassa após secagem, em grade suspensa ao sol durante um dia, foi da ordem de $75 \%$.

A produtividade da lentilha d'água, após a secagem ao sol, resultou em 0,035 $\mathrm{kg} / \mathrm{m}^{2} /$ dia, o que equivale a 126 ton/ha/ano. 
TABELA 4.6 - Produtividade da lentilha d'água

\begin{tabular}{|c|c|c|c|}
\hline Data & Compartimento & Peso Fresco (kg) & Peso após Secagem $1 \mathrm{dia}-(\mathrm{kg})$ \\
\hline $16 / 06 / 02$ & 1 & 6,3 & 1,5 \\
\hline $17 / 06 / 02$ & 2 & 6,9 & 1,6 \\
\hline 18/06/02 & 3 & 5,1 & 1,4 \\
\hline 19/06/02 & 4 & 7,4 & 1,1 \\
\hline 20/06/02 & 1 & 6,2 & 1,6 \\
\hline 21/06/02 & 2 & 6,8 & 1,6 \\
\hline 23/06/02 & 3 & 7,1 & 2,3 \\
\hline 24/06/02 & 4 & 7,9 & 1,9 \\
\hline $25 / 06 / 02$ & 1 & 8,4 & 2,3 \\
\hline 26/06/02 & 2 & 8,1 & 2,1 \\
\hline 27/06/02 & 3 & 7,6 & 2,5 \\
\hline 28/06/02 & 4 & 7,5 & 2 \\
\hline 29/06/02 & 1 & 8,1 & 2,2 \\
\hline 30/06/02 & 2 & 6,9 & 2,5 \\
\hline $01 / 07 / 02$ & 3 & 8,5 & 2,5 \\
\hline 02/07/02 & 4 & 7,8 & 2,7 \\
\hline 03/07/02 & 1 & 8,4 & 2,5 \\
\hline 04/07/02 & 2 & 8,1 & 2 \\
\hline 05/07/02 & 3 & 8 & 1,9 \\
\hline 06/07/02 & 4 & 7,2 & 2,2 \\
\hline 07/07/02 & 1 & 7,7 & 2,5 \\
\hline 08/07/02 & 2 & 7,6 & 2,9 \\
\hline 09/07/02 & 3 & 6,9 & 2,2 \\
\hline 10/07/02 & 4 & 8,2 & 2,6 \\
\hline 11/07/02 & 1 & 8,8 & 2,4 \\
\hline 12/07/02 & 2 & 8,3 & 2 \\
\hline 13/07/02 & 3 & 8,7 & 2,5 \\
\hline 14/07/02 & 4 & 8,4 & 2 \\
\hline
\end{tabular}




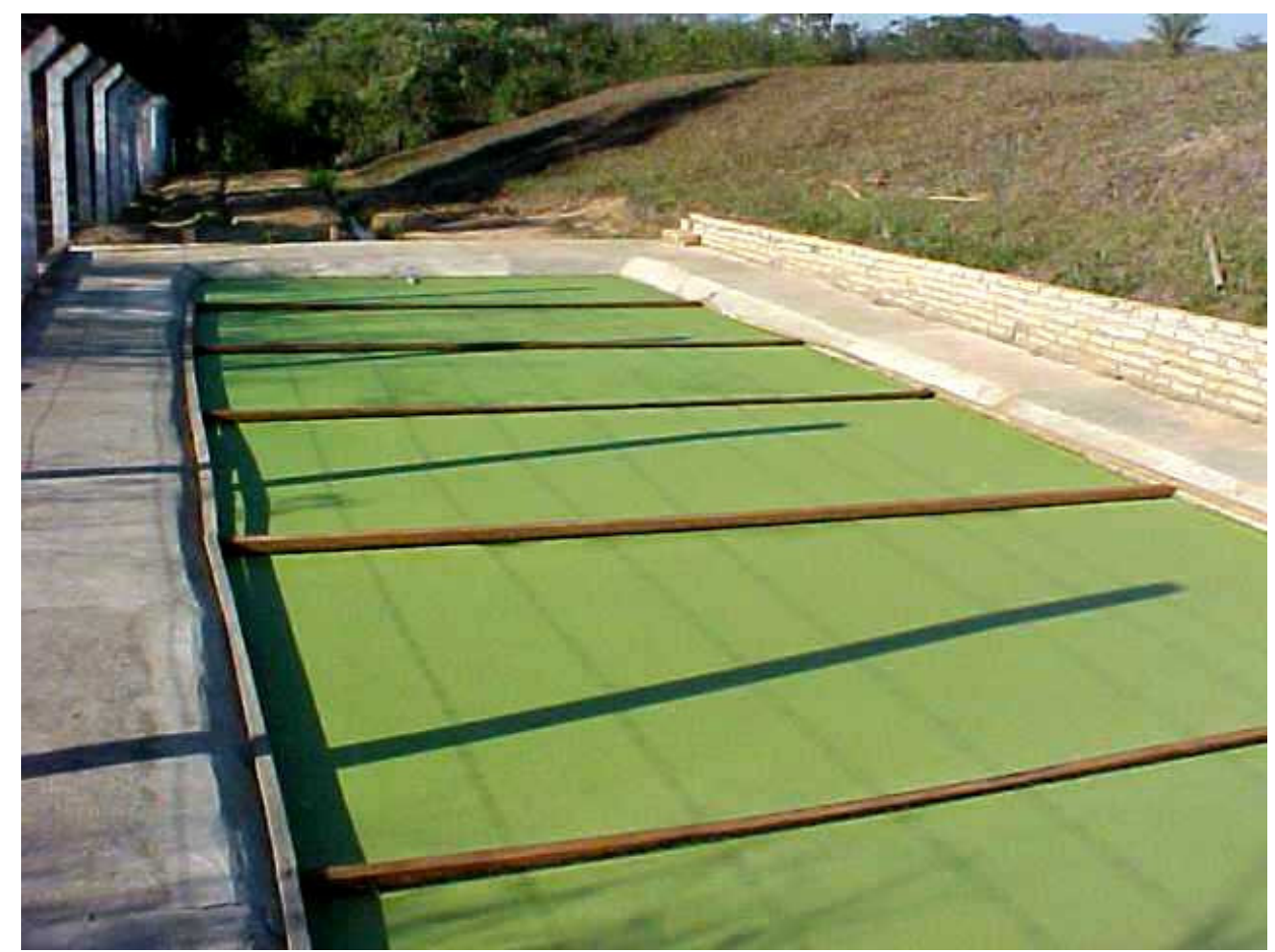

FIGURA 4.6 - Lentilha d'água em fase produtiva

O manejo do aguapé era mais difícil do que o da lentilha d'água, pois o aguapé tem maior peso a ser manuseado, necessita de ferramentas e carrinho de mão para transporte e grande área para disposição da biomassa retirada, além do que, o aguapé, ao ser manuseado, desprende grande quantidade de material que acaba submergindo na lagoa, impedindo a retirada.

A lentilha d'água necessita, para seu manejo, apenas de uma pequena peneira de fácil manuseio e possibilita a retirada quase que completa da biomassa com pequeno desprendimento de material.

\subsubsection{Presença de insetos}

Segundo TENNESSEN (1993), a densidade de larvas em sistema secundário de tratamento de esgotos utilizando macrófitas aquáticas depende da escolha do local pelas fêmeas para deposição de ovos, disponibilidade de alimento e presença ou não de predador natural. Nenhuma ou poucas larvas são encontradas em sistemas naturais (lagoas e pântanos), quando estão cobertos pela lentilha d'água. Entretanto, em lagoas de estabilização com lentilhas d'água, altas densidades de larvas são freqüentemente 
encontradas.

Após 60 dias de operação da lagoa com lentilha d'água, constatou-se presença significativa de larvas de mosquitos e, semelhante ao que aconteceu na lagoa com aguapé, os mosquitos adultos não habitavam o local, mostrando que em ambos os casos a lagoa era utilizada para deposição de ovos.

A TABELA 4.7 mostra a quantidade de indivíduos que se viabilizaram num período de 48 horas, totalizando oito a nove indivíduos viáveis na lagoa com lentilha d'água contra 25 indivíduos viáveis na lagoa com aguapé, fato esse que deve ser decorrente principalmente das folhas da lentilha d'água ficarem sobre a superfície da água e em contato com ela, diminuindo a lâmina d'água disponível para a deposição de ovos. Além disso, as raízes curtas da lentilha d'água não permitem que as larvas se atraquem a elas, facilitando o arraste de parte das larvas para o efluente.

Os demais fatores facilitadores para a reprodução dos mosquitos são comuns às duas espécies de macrófitas estudadas:

- O pouso do mosquito é facilitado pela ausência de marolas;

- Não há predadores naturais.

TABELA 4.7 - Número de indivíduos que eclodiram nos tubos de amostragem da lagoa com lentilha d'água

\begin{tabular}{cccc}
\hline Amostra & Tempo(h) & $\begin{array}{c}\mathrm{N}^{\circ} \text { Indivíduos que } \\
\text { eclodiram }\end{array}$ & Área $\left(\mathrm{cm}^{2}\right)$ \\
\hline 1 & 48 & 9 & 78,5 \\
2 & 48 & 8 & 78,5 \\
3 & 48 & 8 & 78,5 \\
\hline
\end{tabular}

\subsubsection{Análises físico-químicas}

A TABELA 4.8 e Apêndices A, B, C demonstram, a partir de sete amostras compostas, os resultados físico-químicos e bacteriológicos médios do afluente e efluente da lagoa com lentilha d'água e do efluente da lagoa de maturação utilizada como testemunho. 
TABELA 4.8 - Resultados de análises físico-químicas e bacteriológicas do esgoto afluente e efluente da lagoa de maturação com TDH = 6 dias e da lagoa com lentilha d'água com $\mathbf{T D H}=\mathbf{2}$ dias (valores médios de 07 coletas)

\begin{tabular}{|c|c|c|c|c|c|c|}
\hline \multirow[b]{3}{*}{ Parâmetro } & \multirow[b]{3}{*}{ Un. } & \multicolumn{3}{|c|}{ Concentração } & \multirow{2}{*}{\multicolumn{2}{|c|}{ Variação (\%) }} \\
\hline & & \multicolumn{3}{|c|}{ Pontos de coleta } & & \\
\hline & & Afluente & $\begin{array}{l}\text { Lagoa de } \\
\text { maturação } \\
- \\
\text { Efluente }\end{array}$ & $\begin{array}{c}\text { Lagoa } \\
\text { com } \\
\text { lentilha } \\
\text { d'água } \\
\text { Efluente }\end{array}$ & $\begin{array}{l}\text { Lagoa de } \\
\text { maturação }\end{array}$ & $\begin{array}{c}\text { Lagoa com } \\
\text { lentilha } \\
\text { d'água }\end{array}$ \\
\hline Oxigênio Dissolvido & $(\mathrm{mg} / \mathrm{l})$ & 4,8 & 5 & 5,3 & 4,2 & 10,4 \\
\hline Sólidos Totais & $(\mathrm{mg} / \mathrm{l})$ & 590 & 554 & 566 & $-6,1$ & $-4,1$ \\
\hline Sólidos Totais Fixos & $(\mathrm{mg} / \mathrm{l})$ & 366 & 342 & 327 & $-6,6$ & $-10,7$ \\
\hline $\begin{array}{c}\text { Sólidos Totais } \\
\text { Voláteis }\end{array}$ & $(\mathrm{mg} / \mathrm{l})$ & 224 & 212 & 239 & $-5,4$ & 6,7 \\
\hline $\begin{array}{c}\text { Sólidos Suspensos } \\
\text { Totais }\end{array}$ & $(\mathrm{mg} / \mathrm{l})$ & 100 & 76 & 73 & $-24,0$ & $-26,0$ \\
\hline $\begin{array}{c}\text { Sólidos Suspensos } \\
\text { Fixos }\end{array}$ & $(\mathrm{mg} / \mathrm{l})$ & 13 & 16 & 13 & 23,1 & 0,0 \\
\hline $\begin{array}{c}\text { Sólidos Suspensos } \\
\text { Voláteis }\end{array}$ & $(\mathrm{mg} / \mathrm{l})$ & 87 & 60 & 60 & $-31,0$ & $-31,0$ \\
\hline DQO & $(\mathrm{mg} / \mathrm{l})$ & 330 & 278 & 259 & $-15,8$ & $-21,5$ \\
\hline $\mathrm{DBO}_{5}$ & $(\mathrm{mg} / \mathrm{l})$ & 67 & 63 & 53 & $-6,0$ & $-20,9$ \\
\hline Fósforo Total & $(\mathrm{mg} / \mathrm{l})$ & 5,8 & 6,3 & 5,7 & 8,6 & $-2,6$ \\
\hline Condutividade & $\mathrm{dS} / \mathrm{m}$ & 777 & 787 & 859 & 1,3 & 10,6 \\
\hline Coliformes Totais & NMP & $9,2.10^{6 .}$ & $8.10^{6}$ & $8,6 \cdot 10^{6}$ & $-13,0$ & $-6,5$ \\
\hline Coliformes Fecais & NMP & $5,6 \cdot 10^{5}$ & $2,9 \cdot 10^{5}$ & $5,4 \cdot 10^{5}$ & $-48,2$ & $-3,6$ \\
\hline $\begin{array}{c}\text { Nitrogênio Total } \\
\text { Kjedhal }\end{array}$ & $(\mathrm{mg} / \mathrm{l})$ & 42,3 & 40,1 & 38,1 & $-5,2$ & $-9,9$ \\
\hline Nitrogênio Amoniacal & $(\mathrm{mg} / \mathrm{l})$ & 34,5 & 26,6 & 20,8 & $-22,9$ & $-39,7$ \\
\hline
\end{tabular}


- Condutividade elétrica

A lagoa com lentilha d'água apresentou aumento de condutividade de 10,6\%, para TDH de dois dias. Isso mostra que a alteração do volume da lagoa com lentilha d'água é muito maior que na lagoa de estabilização que teve 1,3\% de incremento e que o aumento da concentração de sais em sistemas com lentilha d'água não é desprezível e pode influenciar o equilíbrio biológico, fato esse que deve ser considerado em novos experimentos.

Como na lagoa com lentilha d'água as folhas ficam em contato com a água e possibilitam transferência de calor para a superfície, proporcionaram melhores condições para evaporação e, portanto, aumento maior de condutividade do que aguapé que tem folhas em torno de $20 \mathrm{~cm}$ acima da lâmina d'água, provocando sombreamento e, assim, menor temperatura da superfície.

- Coliformes fecais

Segundo ORON et al. (1998), a remoção de coliformes fecais ocorre em menor proporção em lagoas com lentilha d'água do que em lagoas de estabilização com algas, isso devido ao sombreamento provocado pela lâmina com conseqüente redução de penetração dos raios solares, sendo necessário pós-desinfecção para garantir valores reduzidos de patógenos.

Os resultados obtidos demonstraram ineficácia do sistema de lagoa com lentilha d'água no processo de desinfecção com valores médios de coliformes fecais (NMP) no afluente de $5,6 \times 10^{5}$, e no efluente de 5,4 x $10^{5}$, não apresentando qualquer alteração logarítmica.

Esse fato indica que entre os fatores que concorrem para o processo de desinfecção em lagoa de estabilização de elevados valores de $\mathrm{pH}$, ação dos raios ultravioletas, competição por nutrientes e existência de compostos tóxicos, os raios ultravioletas são de maior importância, pois a lentilha d'água, ao provocar sombreamento na lagoa e impedir a penetração de raios solares, reduz bruscamente a capacidade do sistema de promover a desinfecção.

- Demanda Química de Oxigênio 
Em experimento realizado por SILVA (1982), no laboratório da Extrabes na Paraíba, PE no qual verificou-se o desempenho de uma lagoa de estabilização terciária (sem macrófitas), os resultados obtidos demonstraram baixa eficiência na remoção de DQO, atingindo 9,8\% de matéria orgânica para tempo de detenção hidráulico teórico de 16 dias.

ORON et al.(1998) apontam que a lentilha d'água pode melhorar o desempenho de lagoas terciárias à medida que contribui diretamente para o processo de tratamento de esgoto sanitário pela assimilação direta de componentes orgânicos simples, tais como carboidratos simples e vários aminoácidos.

A DQO do efluente da lagoa de estabilização com lentilha d'água apresentou redução de DQO de 21,5\% para tempo de detenção hidráulico de dois dias, e o sistema de controle apresentou, para um tempo de detenção hidráulico de seis dias, redução de DQO de 15,8\% inferior à lagoa com lentilha d'água, comprovando a eficiência da macrófita aquática na redução de compostos orgânicos quando utilizada em sistemas terciários.

- Sólidos Suspensos Voláteis

Esperava-se, na lagoa de maturação, aumento da concentração de sólidos suspensos voláteis devido à elevada presença de algas em lagoas de estabilização terciárias, mas as medidas indicaram redução de $31 \%$ de SSV o que pode ser atribuído à posição do tubo coletor do efluente que fica submerso $30 \mathrm{~cm}$ em relação à lâmina d'água.

Na lagoa com lentilha d'água, a redução de SSV também foi de $31,0 \%$, mas a coloração do efluente era bastante diferente. Enquanto apresentava-se esverdeado na lagoa de maturação, na lagoa com lentilha d'água tinha a cor acinzentada. Verificou-se, assim, que havia predominância de algas nas amostras da lagoa de estabilização enquanto na lagoa com lentilha d'água os sólidos eram oriundos do material desprendido da biomassa durante o manejo.

Há, assim, um efeito compensatório na lagoa com lentilha d'água, pois enquanto essa macrófita aquática reduz a concentração de algas, a mesma é responsável por aumentar a concentração de sólidos do efluente a partir da sua própria biomassa, que é liberada durante o manejo. 
- Fósforo

A concentração média de fósforo total na lagoa de maturação e lagoa com lentilha d'água foi, respectivamente, de $6,3 \mathrm{mg} / \mathrm{l}$ e $5,7 \mathrm{mg} / \mathrm{l}$. Como a concentração média do afluente foi de $5,8 \mathrm{mg} / \mathrm{l}$, ocorreu aumento da concentração do nutriente na lagoa de maturação em 7,7 \% e redução na lagoa com lentilha d'água de 2,6 \%.

No caso da lagoa de maturação, o aumento pode ser atribuído à posição do tubo coletor efluente, conforme já descrito na página 35.

Na lagoa com lentilha d'água, a redução ocorre segundo HANCOCK (1993), devido aos seguintes fatores: absorção pela lentilha d'água, absorção pelas bactérias e adsorção e precipitação em partículas do solo, sendo o aumento de eficiência na redução de nutrientes uma das grandes vantagens desses sistemas.

KIM e KIM (2000) afirmam que muitos estudos têm sido realizados em várias partes do mundo para discutir o potencial de macrófitas aquáticas na redução de nitrogênio e fósforo total quando utilizados em lagoas de estabilização.

Segundo AL-NOZAILY et al. (2000), parte dos nutrientes do esgoto sanitário é removida pela conversão em proteínas da própria lentilha d'água e removidos do sistema com a colheita da planta, sendo que a lentilha d'água possui capacidade de remoção de fósforo na ordem de $0,9 \mathrm{~kg} / \mathrm{ha} / \mathrm{dia}$.

Os resultados alcançados neste experimento demonstraram que a lentilha d'água tem baixo desempenho na redução de fósforo, com eficiência de remoção de fósforo total de 2,6\%. Essa baixa redução mostra que, apesar de haver incorporação de fósforo na biomassa, a lentilha d'água provoca os mesmos efeitos do aguapé, conforme detalhado na página 35 .

- Nitrogênio

Segundo VAN DER STEEN et al. (1999), sistemas de lagoas de estabilização quando utilizam lentilha d'água aumentam a eficiência de remoção de nutrientes que são parcialmente removidos pela conversão em novas plantas e pela colheita da biomassa.

A lagoa com lentilha d'água alcançou a eficiência de 39,7\% de redução de nitrogênio amoniacal contra 22,9\% de redução para a lagoa testemunho, demonstrando vantagem na aplicação de lentilha d'água quanto à remoção de nitrogênio. 
Resultados próximos foram encontrados por ORON et al. (1998) em um sistema de lagoas em série utilizando lentilha d'água, operando sob temperatura média anual de $27^{\circ} \mathrm{C}$ e elevada insolação, ou seja, condições semelhantes ao do local deste experimento, que obteve redução de $53 \%$ de nitrogênio amoniacal.

- Impacto Ambiental

A lentilha d'água, por não ser nativa do local, provocou grande impacto ambiental na região da lagoa experimental, infectando outras lagoas de tratamento além de lagoas de propriedades vizinhas (FIGURA 4.7), fato que pode ser atribuído principalmente pelo transporte das lentilhas d'água pelos patos, que passaram a habitar o local utilizando a lentilha d'agua como fonte de alimentos. Isso exigiu desinfestação de todos os lagos com trabalhos que perduraram por três meses depois da retirada da lentilha d'água da lagoa.

Este fato demonstra a grande dificuldade de aplicação da lentilha d'água em lagoas de estabilização, indicando elevado risco de infestação de lagoas próximas que podem ter outra predominância de uso como: recreação, captação de água, criação de peixes, representando, assim, riscos econômicos e sociais.

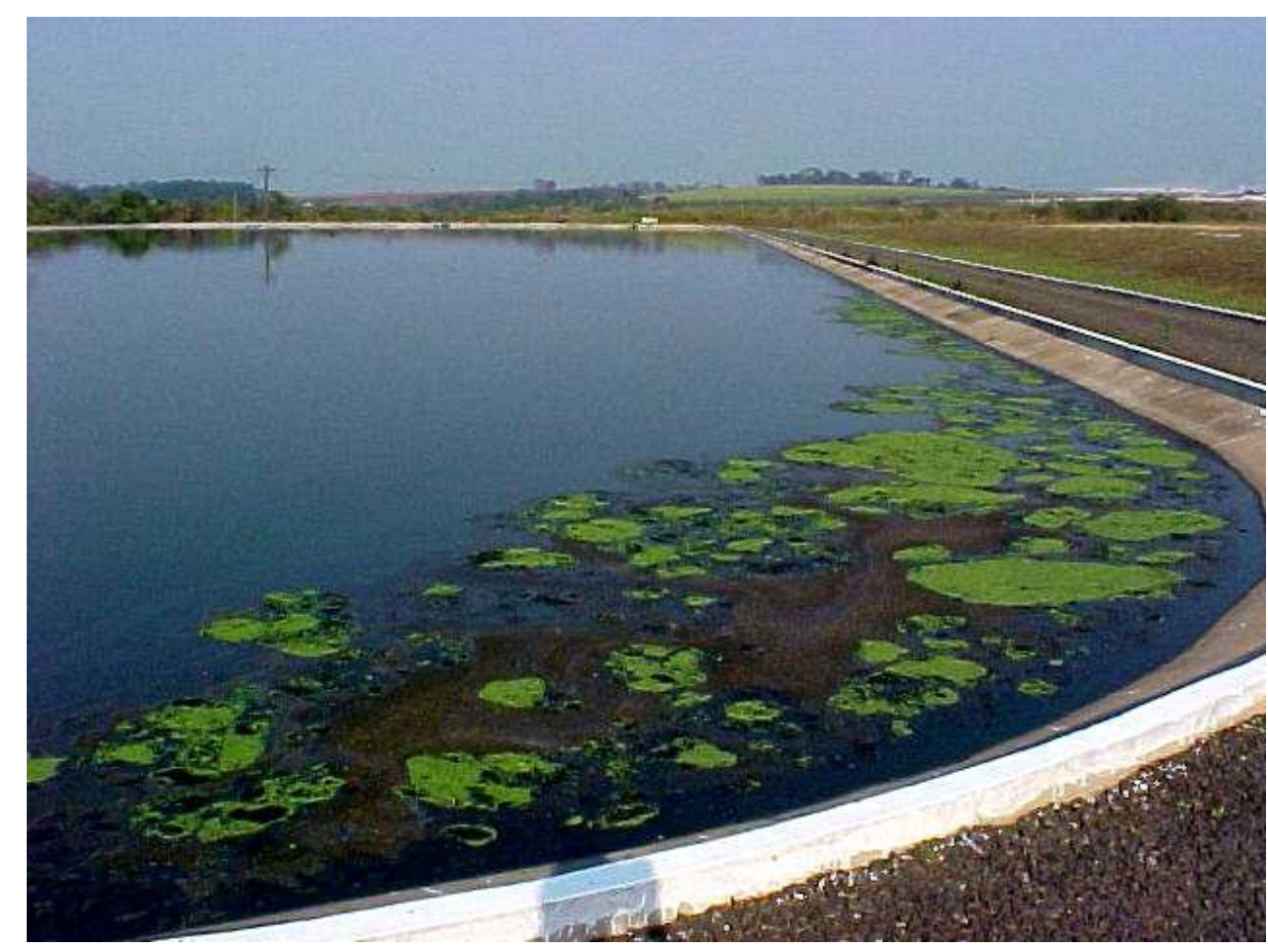

FIGURA 4.7 - Infestação, pela lentilha d'água, de lagoa vizinha à área do experimento - Foto do autor 
TABELA 4.9 - Resultados da eficiência de remoção de parâmetros físico-químicos e bacteriológicos para lagoa piloto com aguapé, lagoa piloto com lentilha d'água e lagoa de maturação da Sabesp dentro do mesmo período do experimento.

\begin{tabular}{|c|c|c|c|c|}
\hline \multirow[b]{2}{*}{ Parâmetro } & \multicolumn{4}{|c|}{ Variação (\%) } \\
\hline & $\begin{array}{l}\text { Lagoa de } \\
\text { maturação }\end{array}$ & $\begin{array}{l}\text { Lagoa } \\
\text { com lentilha } \\
\text { d'água }\end{array}$ & $\begin{array}{l}\text { Lagoa de } \\
\text { maturação }\end{array}$ & $\begin{array}{l}\text { Lagoa com } \\
\text { aguapé }\end{array}$ \\
\hline Período do experimento & \multicolumn{2}{|c|}{ 03/2001 a 08/2001 } & \multicolumn{2}{|c|}{$10 / 2000$ a $01 / 2001$} \\
\hline $\begin{array}{l}\text { Oxigênio } \\
\text { Dissolvido }\end{array}$ & 4,2 & 10,4 & $-11,5$ & $-84,6$ \\
\hline Sólidos Totais & $-6,3$ & $-4,2$ & $-5,7$ & $-7,5$ \\
\hline $\begin{array}{c}\text { Sólidos Totais } \\
\text { Fixos }\end{array}$ & $-6,6$ & $-10,7$ & $-1,5$ & 0 \\
\hline $\begin{array}{c}\text { Sólidos Totais } \\
\text { Voláteis }\end{array}$ & $-5,4$ & 6,7 & $-13,1$ & $-5,6$ \\
\hline Sólidos Suspensos & -24 & -26 & $-41,2$ & $-17,5$ \\
\hline $\begin{array}{c}\text { Sólidos Suspensos } \\
\text { Fixos }\end{array}$ & 23,1 & 0 & -75 & -25 \\
\hline $\begin{array}{c}\text { Sólidos Suspensos } \\
\text { Voláteis }\end{array}$ & -31 & -31 & $-38,2$ & $-16,9$ \\
\hline DQO & $-15,8$ & $-21,5$ & -5 & -30 \\
\hline $\mathrm{DBO}_{5}$ & -6 & $-20,9$ & 6,3 & -15 \\
\hline Fósforo Total & 7,7 & $-2,6$ & 51,2 & 48,8 \\
\hline Condutividade & 1,3 & 10,6 & $-1,8$ & 0,2 \\
\hline Coliformes Totais & -13 & $-6,5$ & $-74,8$ & $-73,6$ \\
\hline Coliformes Fecais & $-48,2$ & $-3,6$ & $-90,3$ & $-99,7$ \\
\hline $\begin{array}{c}\text { Nitrogênio Total } \\
\text { Kjedhal }\end{array}$ & $-5,2$ & $-9,9$ & -17 & $-29,1$ \\
\hline $\begin{array}{l}\text { Nitrogênio } \\
\text { Amoniacal }\end{array}$ & $-22,9$ & $-39,7$ & $-13,8$ & $-19,1$ \\
\hline
\end{tabular}

Os resultados experimentais somados às observações e ações de manejo aguapé 
e lentilha d'água demonstraram que há enormes dificuldades na utilização destas macrófitas no tratamento de esgoto, principalmente pelas seguintes razões:

- não há viabilidade de utilização de plantas com baixo custo econômico, ou seja, mostrou-se impraticável o manejo das plantas por agricultores locais e também a pronta utilização da biomassa no alimento de animais.

- durante o manejo das plantas ocorreu grande desprendimento de biomassa que eleva a concentração de sólidos do efluente, com perda da qualidade e comprometimento da aparência visual do efluente.

- a disposição intermediária da biomassa, ou seja, a disposição das plantas nos arredores da lagoa enquanto se aguarda o destino final, é bastante complicada, pois a biomassa entra em decomposição rapidamente, gerando chorume além, de produzir condições favoráveis para proliferação de moscas.

- há necessidade de utilização de maior número de funcionários e equipamentos para operação das lagoas, com a finalidade de manejo das plantas, implantação de infra-estrutura para armazenamento temporário da biomassa retirada e equipamentos e tecnologia para disposição final da biomassa. Tais fatores representam grande elevação dos custos operacionais das lagoas de estabilização, refletindo assim negativamente em uma das maiores vantagens desses sistemas que é o baixo custo e facilidade de operação.

Concluiu-se que mesmo com aumento de eficiência de remoção de $\mathrm{DQO}, \mathrm{DBO}_{5}$, Nitrogênio Kjedahl e Amoniacal, para ambos os casos: lagoa com aguapé e lagoa com lentilha d'água, conforme TABELA 4.9, os inúmeros problemas operacionais e aumento de custos que surgem da aplicação das macrófitas aquáticas tornam desaconselhável o uso de aguapé e lentilha d'água em lagoas de tratamento de esgoto com características operacionais e ambientais semelhantes à do sistema estudado nesta pesquisa. 


\section{E ESTRATIFicaÇão tÉRMiCa EM LaGoaS DE ESTABILIZAÇÃO}

\subsection{Introdução}

Nesta parte do trabalho foi avaliada a estratificação térmica e a hidrodinâmica da lagoa de estabilização, em escala piloto, e as interferências sobre esses fatores por meio do uso de chicaneamento.

O objetivo do trabalho foi verificar entre três diferentes configurações físicas da lagoa: sem chicaneamento, com chicaneamento longitudinal e com chicaneamento longitudinal e transversal, a que apresentasse condição hidrodinâmica mais favorável ao processo de depuração do esgoto sanitário. Dessa forma, se estudou para essas três configurações diversos parâmetros e a inter-relação dos mesmos: perfil de temperatura e oxigênio dissolvido, concentração de DQO na coluna d'água, Número de Dispersão (d), porcentagem de volume ativo, porcentagem de volume morto e tempo de detenção hidráulico real.

\subsection{Revisão bibliográfica}

\subsubsection{Comportamento hidráulico de lagoas de estabilização}

Segundo KELLNER e PIRES (1999) e DOREGO e LEDUC (1996) os processos de autodepuração que ocorrem em lagoas de estabilização estão intimamente ligados às 
suas características hidrodinâmicas, sendo que as lagoas de estabilização comportam-se hidraulicamente como reatores de escoamento disperso, ou não ideal, mas dependendo da geometria da lagoa e número de lagoas em série tem se considerado nos projetos tanto a ocorrência de mistura completa quanto de escoamento pistonado.

A não idealidade do escoamento no interior de uma lagoa pode ser conhecida por meio de uso de traçadores, que são injetados de forma contínua ou instantânea no afluente da lagoa, e medindo-se as concentrações desse traçador no efluente em períodos de tempo determinados (COSSIO, 1993; DOREGO, 1996; KELLNER, 1999).

Quando um traçador é injetado em uma lagoa obtêm-se curvas que relacionam a concentração do traçador ao tempo de percurso na lagoa como demonstrado na FIGURA 5.1.
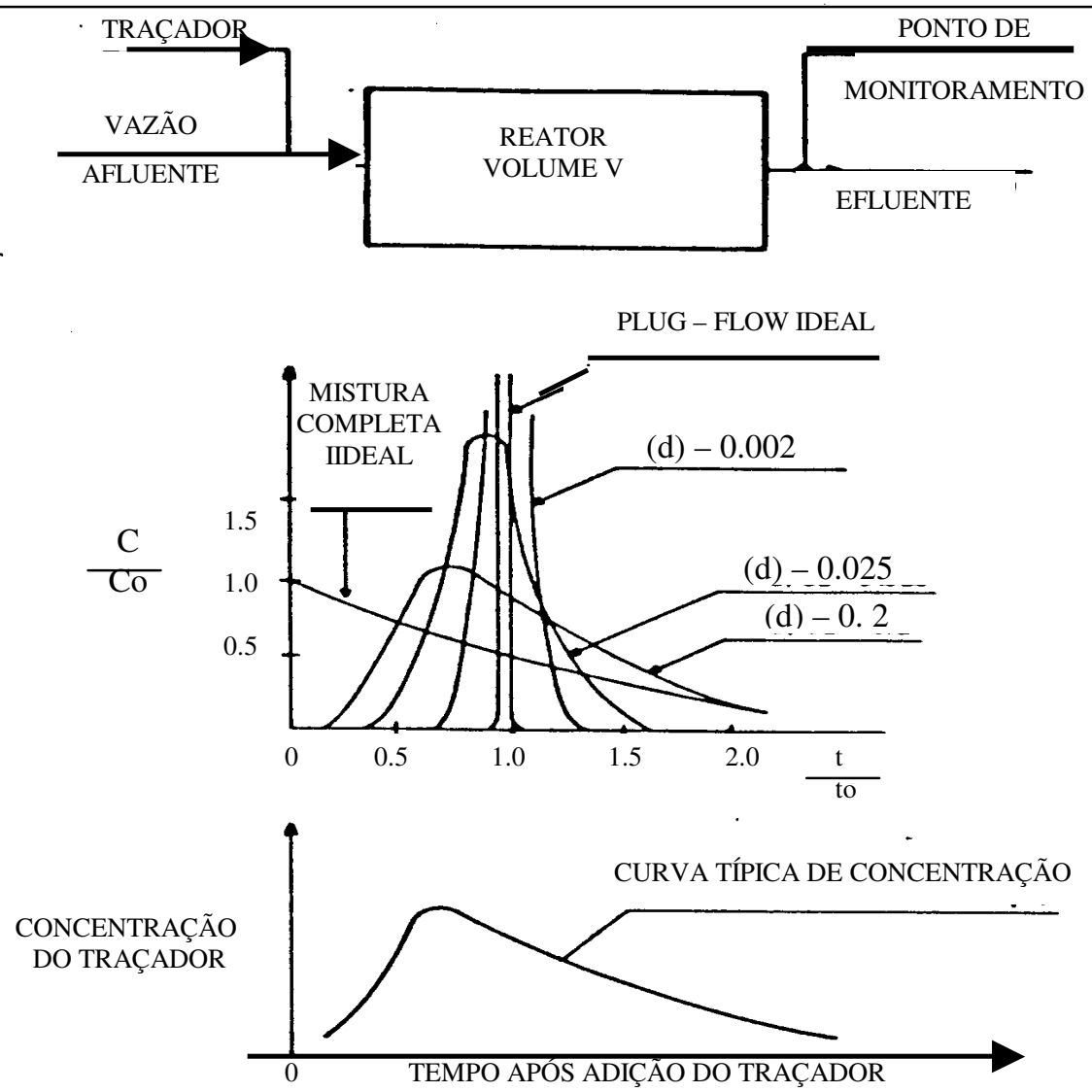

$\mathrm{C}=$ concentração do traçador no efluente;

$\mathrm{Co}=$ concentração do traçador se toda a quantidade do traçador fosse misturada uniformemente no volume total do reator $(\mathrm{Co}=\mathrm{Mo} / \mathrm{V})$;

$\mathrm{t}$ = tempo quando foi coletado o efluente;

to = tempo de detenção hidráulica teórica (volume/vazão).

(d) = número de Dispersão (admensional)

FIGURA 5.1 - Curva de resposta típica de um reator sendo avaliado por meio de traçadores. Fonte: Adaptado de Levenspiel (1974) 
As concentrações na saída do reator dependem do tipo de mistura ocorrida no interior do mesmo.

Os diversos tipos de escoamento são:

a) Escoamento tipo pistão.

O escoamento tipo pistão ou "plug-flow" é definido como sendo aquele onde as partículas contidas no escoamento saem da lagoa na mesma ordem física em que entraram, não havendo mistura ou dispersão. Todos os componentes do afluente permanecem o mesmo tempo na lagoa, que é o tempo de detenção hidráulico teórico (V/Q).

Tratando-se do substrato contido no esgoto (matéria orgânica, nutrientes etc.), a reação para escoamento pistonado é expressa por:

$$
\mathrm{S}=\mathrm{S}_{\mathrm{o}} \cdot \mathrm{e}^{-\mathrm{K} \cdot \mathrm{t}}
$$

Onde:

$\mathrm{S}=$ concentração do substrato no efluente ;

$\mathrm{S}_{\mathrm{o}}=$ concentração do substrato no afluente;

$\mathrm{t}=$ tempo em que o esgoto é submetido ao tratamento $(=\mathrm{V} / \mathrm{Q})$;

$\mathrm{K}=$ constante de remoção.

A hipótese é de que o valor de K permaneça constante em todo o volume da lagoa, enquanto que a concentração do esgoto vai sendo reduzida ao longo da mesma, isto quer dizer que a remoção do esgoto é elevada a montante do sistema, enquanto que próxima à saída, a remoção é bem menos eficiente, uma vez que a taxa de reação é diretamente proporcional à concentração de esgoto biodegradável (primeira ordem). Isto ocorre nos reatores onde o comprimento é bem maior que a largura (tanque de aeração longo, lagoa de estabilização longa e estreita etc). Nota-se, deste modo, que a equação (1) é adequada para expressar remoção de esgoto sob escoamento tipo pistão. 
$\mathrm{Na}$ prática, porém, nenhuma lagoa apresenta o comportamento ideal acima descrito, pois sempre há mistura em algum grau.

b) Escoamento tipo mistura completa

Inversamente ao escoamento tipo pistão, a mistura completa é aquela onde todas as partículas afluentes são espalhadas em todo o volume da lagoa, homogeneamente, assim a concentração das partículas no efluente é a mesma encontrada em todos os pontos do reator.

A equação (2) é a utilizada para o caso do escoamento tipo de mistura completa. Na prática, o emprego da mistura completa traz uma série de vantagens operacionais, tais como o amortecimento de choques de cargas, de vazão, do ingresso de materiais tóxicos etc., tornando o processo biológico mais estável e seguro.

$$
S=\frac{S o}{1+K(V / Q)}
$$

ou

$$
S=\frac{S o}{1+K t}
$$

Com a mesma notação da equação (1)

c) Escoamento de mistura intermediária.

Tanto o escoamento tipo pistão quanto em mistura completa são casos ideais extremos, inexistentes na prática. $\mathrm{O}$ escoamento da mistura intermediária é o modelo escoamento entre aqueles extremos, onde cada partícula do escoamento permanece um tempo distinto no reator. WEHNER e WILHELN (1956) desenvolveram equação para mistura não ideal, cuja aplicação está sendo mais intensa nos últimos anos no campo de tratamento de esgotos. A solução da equação é numérica:

$$
\frac{\mathrm{S}}{\mathrm{S}_{\mathrm{o}}}=\frac{4 a\left(e^{1 / 2 d}\right)}{(1+a)^{2} e^{a / 2 d}-(1-a)^{2} e^{-a / 2 d}}
$$




\author{
$\mathrm{a}=(1+4 \mathrm{Ktd})^{1 / 2}($ adimensional $)$ \\ $\mathrm{t}$ = tempo de detenção hidráulico teórico (=V/Q) (dias); \\ d = Número de Dispersão (adimensional); \\ $\mathrm{K}=$ constante de remoção de primeira ordem a uma temperatura constante $\mathrm{T}$ \\ $\left(\operatorname{dias}^{-1}\right)$ \\ $S_{0}$ e $S=$ respectivamente, concentração inicial e final do substrato.
}

Para o caso de uma substância não reagente (inerte), $K=0$, define-se um fator denominado de Número de Dispersão (d). No pistonado teórico, não havendo mistura, $(d)=0$. Na mistura completa teórica, a dispersão é infinita, sendo $(\mathrm{d})=\infty$, para o escoamento de mistura intermediário, o valor de (d) está, assim, entre zero e infinito. A curva de resposta de um reator sendo avaliado por meio de traçadores é demonstrada na FIGURA 5.1.

Os fatores que afetam a dispersão no reator biológico são basicamente os seguintes:

- tipo de escoamento;

- geometria da lagoa;

- tipo e localização dos dispositivos de entrada e de saída;

- velocidade do escoamento afluente e sua variabilidade;

- diferença de densidade e de temperatura entre o escoamento afluente e o fluído contido no reator biológico;

- condições ambientais.

Nota-se, assim, que um mesmo reator biológico pode apresentar valores distintos de (d), conforme o escoamento, velocidade, desnível térmico, direção, sentido e intensidade do vento etc. 
A TABELA 5.1 apresenta alguns valores estimados de (d) dos diversos tipos de reatores biológicos.

\section{TABELA 5.1 - Relação entre o tipo de tratamento utilizado em esgoto sanitário e faixa provável de (d)}

\begin{tabular}{|c|c|}
\hline Tipo de tratamento & (d) (faixa provável) \\
\hline decantador retangular & $0,2-2,0$ \\
\hline$\underline{\text { tanque de aeração de lodo ativado }}$ & $0,1-1,0$ \\
\hline longo, tipo "plug-flow" & $3,0-4,0$ ou mais \\
\hline tipo mistura completa & $0,1-1,0$ \\
\hline$\underline{\text { lagoa de estabilização }}$ & $1,0-4,0$ ou mais \\
múltipla, em série & $0,2-1,0$ \\
longa, retangular & $3,0-4,0$ ou mais \\
\hline lagoa aerada mecanicamente & \\
longa, retangular & \\
\hline
\end{tabular}

Fonte: Adaptado de Levenspiel (1974).

Na prática, os valores típicos de (d) nos reatores biológicos para tratamento de esgotos estão na faixa entre 0,1 e 4,0. Assim, uma lagoa está próxima da mistura completa para valores de (d) superiores a 3 ou 4; e próxima do pistonado se (d) for inferior a 0,2 .

Substituindo-se os números de dispersão, citados na TABELA 5.1, na equação (4) verifica-se que sob mistura completa é difícil obter eficiências elevadas (superior a 97\%), enquanto que sob escoamento pistonado é possível obter remoção superior a 99,9\%, no entanto, deve-se observar que estes resultados são apenas teóricos.

Conclui-se, que o fator determinante nos modelos de escoamentos é a determinação do Número de Dispersão (d). 
Utilizando uma substância traçadora é possível determinar o Número de Dispersão (d) e realizar análise quantitativa e qualitativa do escoamento no interior de um reator.

\subsubsection{O fenômeno da estratificação térmica}

Os valores e a distribuição da temperatura da massa de água de uma lagoa de estabilização exercem um papel fundamental nas características desses sistemas, devido principalmente aos seguintes fatores:

- Os processos físico-químicos e biológicos dependem dos valores de temperatura.

- O processo de mistura está intimamente relacionado com a termoclina, que influencia no transporte de matéria na coluna d'água.

- A estratificação térmica diminui o volume útil da lagoa, provocando curto circuito hidráulico e conseqüente redução no tempo de detenção hidráulico.

Na FIGURA 5.2 se observa, pelas diferenças de tonalidades, que o escoamento ocorre na superfície da lagoa sugerindo elevado grau de estratificação térmica e curtocircuito com redução do tempo de detenção hidráulico e grande espaço morto.

Segundo DOR et al. (1993) a distribuição de temperatura em uma lago não é uniforme sendo que na coluna líquida verifica-se três camadas: o epilimnio, camada superior, quente, turbulenta, de pouca espessura, com elevado teor de oxigênio dissolvido e presença de luz solar; o metalimnio, camada intermediária onde se encontra a termoclina e o hipolimnio, mais profundo, espesso, escuro, anóxico e com baixos níveis de turbulência. $\mathrm{O}$ autor considera que este fenômeno pode ocorrer em lagoas, mesmo de pequena profundidade, devido à alta turbidez da massa líquida.

VANZO (1990) ao estudar lagoas de estabilização na região de Franca, SP verificou que elas apresentam elevado grau de estratificação, sendo que a massa do hipolimnio faz com que o volume efetivo da lagoa seja diminuído, como se o fundo fosse a camada que separa o hipolimnio do metalimnio, diminuindo o tempo de detenção hidráulico do sistema. 
Em estudos realizados por COSSIO (1993) em San Juan, México observaram-se grande curto-circuito nas lagoas de estabilização, basicamente devido ao efeito da estratificação.

De acordo com MORENO (1990), em lagoas de estabilização a termoclina separa duas camadas claramente diferenciadas que são o eplilimnio, camada superior aeróbia, e o hipolimnio, camada inferior anaeróbia.

LLORENS et al. (1992) afirmaram que tanto quanto em outros corpos, as lagoas sofrem o processo de estratificação térmica, que se aprofunda no verão, com termoclina bastante definida.

KELLNER e PIRES (1998) concordaram com essa afirmação e apontaram que as lagoas de estabilização, apesar de apresentarem baixa profundidade, têm elevada turbidez favorecendo a ocorrência da estratificação térmica principalmente no verão.

Uma das maneiras de interferir no processo de estratificação térmica é o uso de chicaneamento que melhora a eficiência hidráulica da lagoa à medida que influencia no regime de escoamento e no grau de mistura da massa líquida alterando o tempo de detenção hidráulico e a dispersão do esgoto no interior do sistema (KILANI E OGUNROMBI, 1984).

O objetivo desse trabalho foi estudar o comportamento hidráulico de lagoas de polimento, recebendo esgoto sanitário, utilizando-se dois tipos de chicaneamento: longitudinal e longitudinal e transversal e as respostas do sistema quanto ao tempo de residência e o Número de Dispersão (d) para cada tipo de configuração, comparando com um sistema sem chicaneamento (controle). 


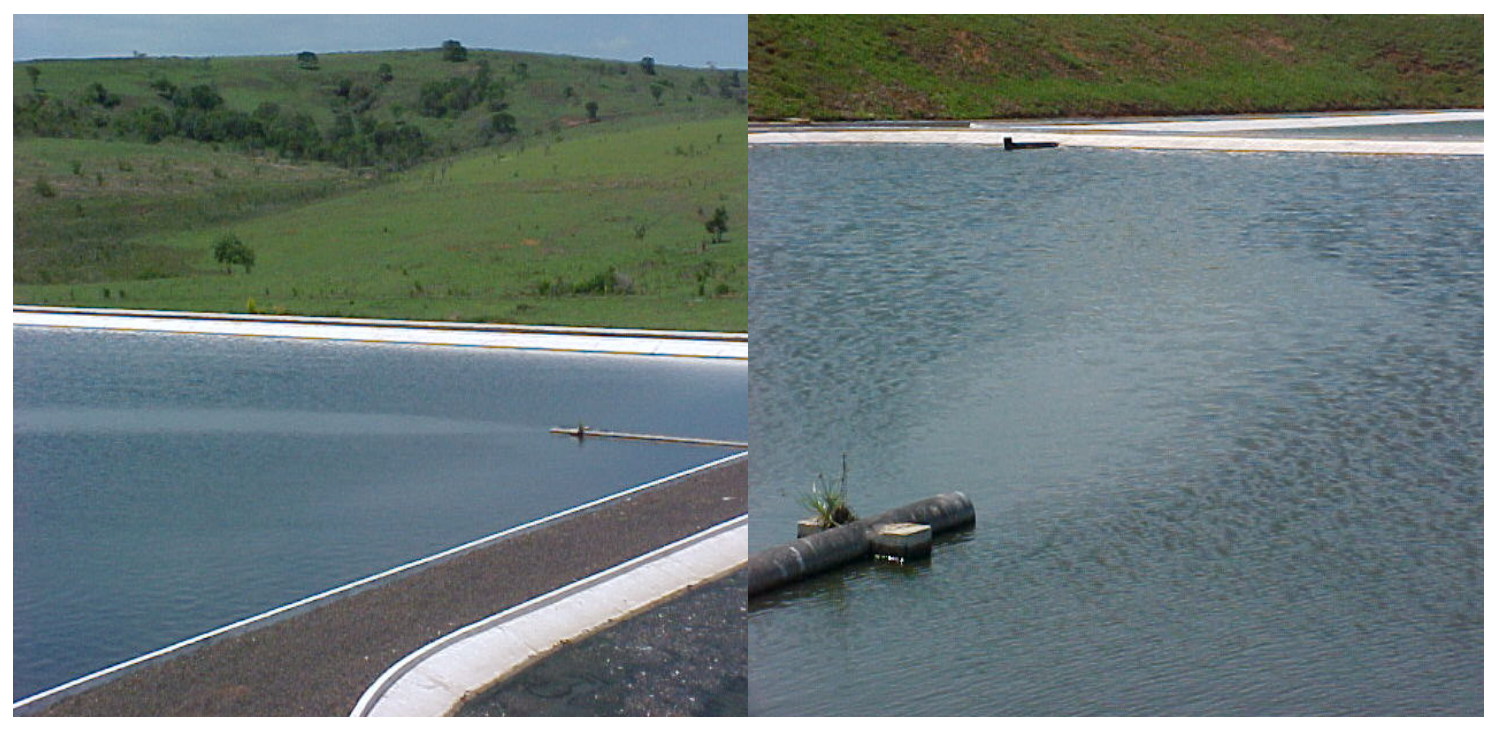

FIGURA 5.2 - Escoamento preferencial devido à estratificação térmica e ao posicionamento de dispositivos de entrada e saída - Lagoa de Estabilização Facultativa - Presidente Alves, SP.

Fonte: Fotografias do autor

\subsubsection{Características hidráulicas e influência da estratificação térmica no processo de depuração em lagoas de estabilização}

As características hidráulicas de uma lagoa são influenciadas pela estratificação térmica sendo, esse fenômeno, essencial para representar a biodegradação em lagoas para prever sua eficiência, pois é importante sob qualquer condição ser mantido maior tempo possível de contato entre o esgoto e os microrganismos existentes no sistema para alcançar o melhor nível de tratamento necessário (SIMI e MITCHELL, 1999; KELLNER, 2000; FERRARI, 1996).

De acordo com LLORENS et al. (1992) e TORRES et al. (1997), os valores e a distribuição da temperatura na massa de água de uma lagoa exercem papel fundamental no desempenho desses sistemas, pois os processos físico-químicos e biológicos e o transporte de matéria na coluna d'água dependem da temperatura, concluindo que na engenharia sanitária a eficiência da maioria dos processos e operações é intimamente ligada ao tempo de detenção hidráulico do fluido e o regime do escoamento no sistema .

MARECOS DO MONTE e MARA (1987) ao estudar lagoas de estabilização na cidade de Vidigueira, Portugal, verificaram que a eficiência do tratamento em lagoas de estabilização depende de muitos fatores e suas inter-relações, mas um fator crucial é o 
regime hidráulico caracterizado pelo espaço morto e grau de dispersão do escoamento, sendo que essas características hidráulicas de uma lagoa são os fatores de maior importância no desempenho desses sistemas.

Segundo KELLNER e PIRES (1999)... “entre os problemas hidrodinâmicos e limnológicos que a estratificação térmica acarreta está a diminuição do volume da zona ativa (volume útil) e conseqüentemente do tempo de detenção hidráulico.”

TORRES et al. (1997) em experimento realizado na lagoa de estabilização de Murcia, Espanha verificaram que o volume ativo da lagoa variou entre $70 \%$ do volume da lagoa no inverno e $22 \%$ do volume total no verão. O Número de Dispersão (d) para a zona ativa foi 0,47 para o inverno e de 0,72 para o verão.

MORENO (1990), observou elevado grau de curto-circuito em lagoas, com resultados de volume ativo variando entre $30 \%$ e $58 \%$ do volume total das mesmas.

Em experimentos realizados por MARECOS DO MONTE e MARA (1987) em Vidigueira, Portugal foram encontrados valores de volume ativo em lagoas entre $34 \%$ a $73 \%$ do volume total.

LLORENS et al. (1992), em estudo realizado em uma lagoa de estabilização tratando resíduo doméstico na cidade de Murcia, Espanha concluíram que a estratificação térmica afeta a concentração de DQO a diferentes profundidades e que uma vez estabilizado a termoclina ocorre aumento de DQO no hipolimnio e maior estabilização da matéria orgânica na superfície da lagoa. Esse estudo demonstrou ainda que há distribuição vertical da DQO com valores mínimos na superfície e valores máximos no fundo, onde ocorre zona morta.

DOREGO e LEDUC (1996) estudaram o fenômeno de estratificação térmica em um sistema de lagoas de estabilização em Quebec, Canadá e observaram significante curto-circuito com volume ativo entre $61 \%$ e $81 \%$ do volume total com valores de coeficiente de dispersão entre 0,395 e 0,487 .

SIMI e MITCHEL (1999) verificaram em um experimento realizado em uma lagoa com macrófitas emergentes em Bulwer Island, Austrália que 70\% do volume da lagoa podia ser considerado ativo e $30 \%$ referia-se a espaço morto. Os autores consideraram um bom resultado, pois afirmam que outros resultados experimentais 
demonstram que as lagoas operam normalmente com valores de volume ativo entre $10 \%$ a $30 \%$ do volume total.

Segundo KELLNER e PIRES (1999) a estimativa do número de dispersão de lagoas de estabilização representa um valor importante tanto para o projeto quanto para a operação de lagoas de estabilização.

COSSIO (1993), após uma prova de traçadores realizado em lagoa facultativa na cidade de Corine, USA obteve Número de Dispersão $(d)=0,578$ e tempo de detenção hidráulico real médio de 13,96 dias para um tempo de detenção hidráulico teórico de 22 dias. Esses resultados apontam volume útil de $63 \%$ do volume total. Em estudos realizados em San Juan, Espanha o autor observou grandes curto-circuitos nas lagoas avaliadas com Número de Dispersão (d) entre 0,38 e 0,82 no verão.

TORRES et al. (1997) ao realizarem ensaio com traçador Rodamina B em uma lagoa de estabilização de $8 \mathrm{~m}$ de profundidade que recebe efluentes da Universidade de Murcia, Espanha verificaram em determinada fase do experimento que a concentração do corante era menor entre a superfície e um metro de profundidade, em relação às camadas inferiores que apresentavam concentrações maiores. Esse fenômeno foi explicado pelo aumento da temperatura atmosférica e conseqüente estratificação térmica da lagoa. Os autores concluíram que como a entrada do afluente se dá pela superfície da lagoa e a saída a 0,6 m de profundidade, a zona onde havia algum movimento e renovação do fluido era somente a camada entre a superfície e a profundidade de aproximadamente um metro.

Neste mesmo experimento após alguns dias de monitoramento houve uma queda brusca na temperatura atmosférica provocando redução da concentração do traçador na camada superior e aumento nas camadas mais inferiores, sugerindo que a zona ativa ficou comprimida entre o centro e o fundo da lagoa.

MORENO (1990) estudando lagoas de estabilização em operação em diversos locais na Espanha concluiu que os resultados de porcentagem de volume morto mostram um alto grau de curto-circuito e sugere entre outras medidas o uso de chicanas para melhorar a eficiência hidráulica das lagoas de estabilização. 
MARECOS DO MONTE e MARA (1987) analisando as lagoas de Vidigueira e Portimão em Portugal encontraram como resultados Número de Dispersão (d) e tempo de detenção hidráulico conforme TABELA 5.2 e concluíram que a mistura foi muito maior no inverno do que no verão na lagoa de Portimão. Os autores acreditam que esse fenômeno também ocorre em Vidigueira, mas é mascarado pelas diferenças entre os tempos de detenção que variam com as estações do ano.

TABELA 5.2 - Resultado do tempo de detenção hidráulico e Número de Dispersão (d) das lagoas de Vidigueira e Portimão, Portugal

\begin{tabular}{c|c|c|c|c}
\hline \multirow{2}{*}{$\begin{array}{c}\text { Tempo de } \\
\text { detenção } \\
\text { hidráulico } \\
\text { (dias) }\end{array}$} & \multicolumn{2}{|c|}{ Lagoa Facultativa de Vidigueira } & \multicolumn{2}{|c}{ Lagoa Facultativa de Portimão } \\
\cline { 2 - 5 } & Verão & Inverno & Verão & Inverno \\
\hline Teórico & 78,9 & 27,1 & 13,5 & 12,4 \\
Real & 27,7 & 20,4 & 16,9 & 17,7 \\
Número de & 0,523 & 0,574 & 0,371 & 0,595 \\
\hline
\end{tabular}

Fonte: Adaptado de MARECOS DE MONTE e MARA (1987).

Em estudo conduzido por DOREGO e LEDUC (1996) em Quebec, Canadá, foi avaliado um sistema de tratamento de esgoto sanitário composto por três lagoas facultativas aeradas seguida de lagoa de maturação em série. Observou-se em todas as lagoas que o pico de concentração do traçador no efluente era geralmente menor do que em $10 \%$ do TDH teórico sugerindo elevado curto-circuito. A lagoa de maturação, que não possui aeração mecânica, apresentou um pico de concentração em $6 \%$ do TDH teórico para esse mesmo estudo, com Número de Dispersão (d) igual a 0,487.

\subsection{Procedimentos experimentais}

Esse trabalho se limitou ao estudo hidráulico da lagoa de estabilização em escala piloto, sendo que a eficiência do sistema foi inferida teoricamente a partir da equação 
(4), item 5.2.1, pois os experimentos foram realizados em períodos diferentes sob condições ambientais distintas não permitindo a comparação direta de eficiência.

\subsubsection{Método para determinação do escoamento interno de lagoas de estabilização}

A técnica de estímulo-resposta que utiliza traçadores fluorescentes, para determinação do tempo de residência real e de coeficiente de dispersão em reatores em geral, e em lagoas de estabilização, em particular, é consagrada, encontrando-se exemplos de aplicação desse método nos trabalhos de KELLNER e PIRES (1999), MORENO (1990), TORRES et al. (1997), entre outros.

A seleção de um traçador aceitável deve considerar a influência, sobre sua estabilidade, das elevadas concentrações de microrganismos, de matéria orgânica, de sólidos em suspensão e da exposição da fase líquida à luz solar por longos períodos. $\mathrm{O}$ traçador fluorescente escolhido deve apresentar alta detectabilidade, não apresentar decaimento fotoquímico e biológico, ser atóxico ao ser humano e aos organismos aquáticos, além de baixo custo (COSSIO, 1993; FERRARI et al., 1996, MARECOS DO MONTE e MARA,1987).

Uma revisão na literatura, em pesquisas que envolvem estudos de hidrodinâmica de lagoas de estabilização, indica que o corante fluorescente Rodamina WT pode ser empregado com segurança nos ensaios de traçadores em lagoas sendo esse o corante que foi selecionado para ser utilizado nos ensaios correspondentes a essa pesquisa.

- Método para caracterização qualitativa do escoamento

Este modelo que se baseia no tempo que as moléculas individuais permanecem no recipiente, ou seja, qual a distribuição dos tempos de residências (DTR) do fluido que está escoando.

A distribuição do tempo de residência de um traçador é representada pela "curva de distribuição da idade”. Essa curva é obtida experimentalmente ao fornecer à entrada 
da corrente um sinal em forma de pulso de um traçador e medir sua concentração na corrente de saída do recipiente (Ci) ao longo do tempo (ti).

Para caracterização hidrodinâmica do escoamento tubular disperso de grande intensidade LEVENSPIEL (1974) apresenta as equações (5) e (6) que representam respectivamente a variança e média dessa família de curvas:

$$
\begin{aligned}
\sigma_{t}^{2} & =\frac{\delta^{2}}{t_{m}^{2}}=2 d-2 d^{2} \cdot\left(1-e^{-\frac{1}{d}}\right) \\
\bar{\theta}_{C} & =\frac{t_{m}}{t}
\end{aligned}
$$

$\sigma_{t}^{2}:$ variança adimensional

$\delta^{2}$ : variança da curva $\mathrm{Ci}$ x Ti em unidades de tempo

d : Número de Dispersão

$\mathrm{t}_{\mathrm{m}}$ : tempo médio de residência do fluido

t : tempo de detenção hidráulico teórico 
A FIGURA 5.3 mostra a curva C em reatores para várias extensões de agitação.

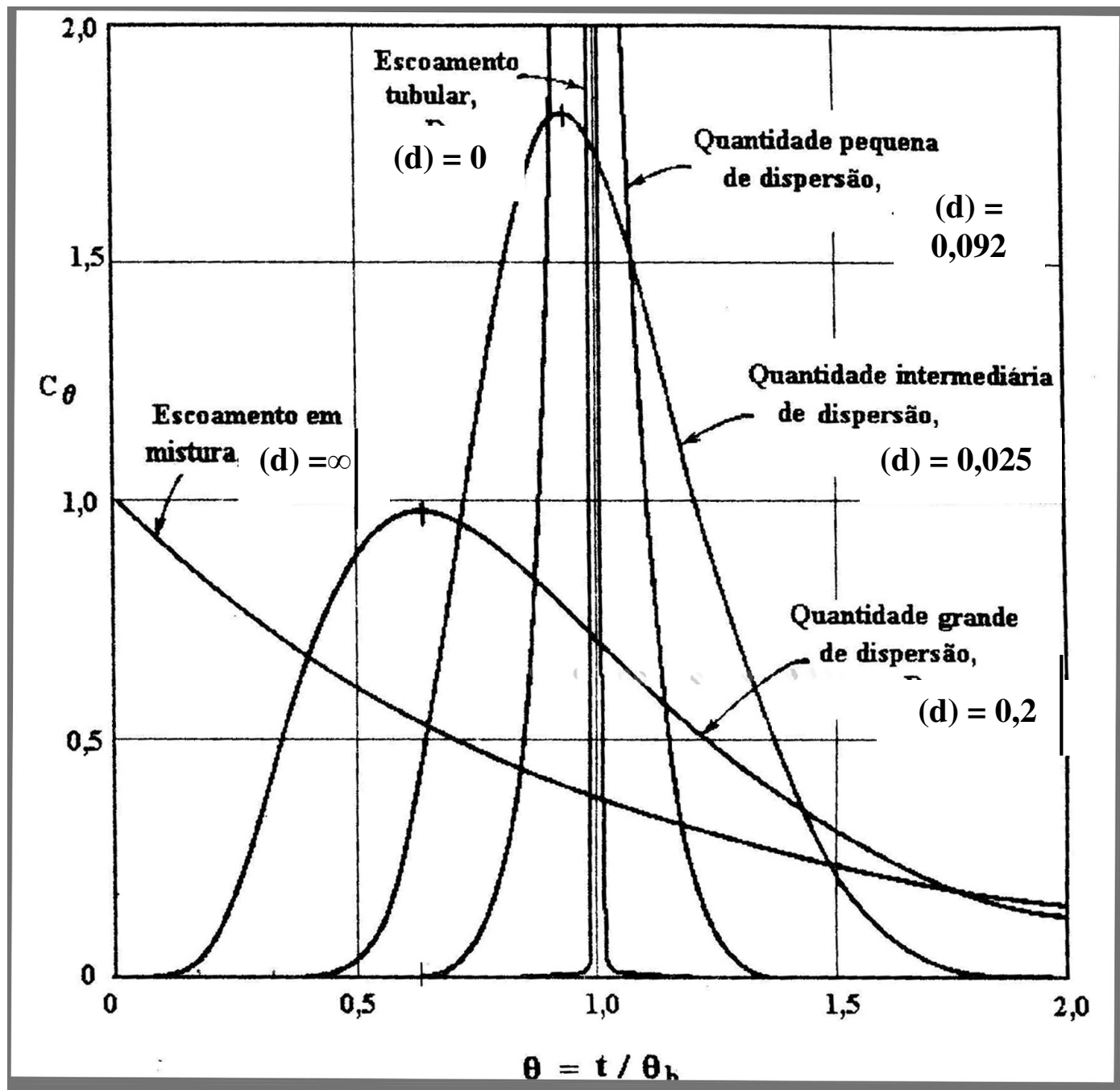

FIGURA 5.3 - Curva de resposta C em reatores para várias extensões de agitação. Fonte: LEVENSPIEL (1974). 
- Método para Avaliação Quantitativa do Escoamento

Segundo LEME (1990) o método convencional para avaliação da eficiência hidráulica de um escoamento que emprega os valores de tendência central da curva e o Número de Dispersão (d) apenas fornecem indicações que permitem uma avaliação qualitativa dessa eficiência. Esses valores não fornecem um meio no qual é possivel determinar numericamente a existência de cada uma das quatro condições importantes para avaliação da eficiência dos reatores que são: porcentagem do escoamento em regime pistonado, porcentagem do escoamento operando em mistura completa, volume eficiente e volume morto ou ineficiente.

REBHUN e ARGAMAN (1965) propuseram um modelo hidrodinâmico para o estudo de tanques de sedimentação que tem sido usado para reatores químicos em geral. O modelo é baseado em trabalho apresentado por WOLF e RESNICK (1963), que demonstraram, por meio de estudos em modelos reduzidos, quais os fatores que intervêm na variação do tempo de detenção hidráulico dos decantadores, quantificando os mesmos.

REBHUN e ARGAMAN (1965) consideraram que em um tanque de sedimentação o escoamento é dividido em pistonado e mistura completa e que há uma fração de espaço morto e para essas condições, por meio de balanço de massa, chegaram a função $F(t)$ descrita por:

$$
F(t)=1-e^{\frac{-1}{(1-p)(1-d)}\left[\frac{t}{T}-p(1-d)\right]}
$$

d : fração do volume morto no recipiente

1-d : fração do volume útil no recipiente

p : fração do escoamento pistonado

1-p : fração de escoamento em mistura completa

$\mathrm{F}(\mathrm{t}): \mathrm{C} / \mathrm{C}_{0}$ 
A partir desse modelo é possível obter medida quantitativa com significado físico do escoamento.

No APÊNDICE $\mathrm{P}$ encontra-se a descrição detalhada do método de análise proposto por REBHUN e ARGAMAN (1965).

\subsubsection{Medidas do tempo de detenção hidráulico real}

As medidas de concentração do traçador foram tomadas conforme descrito no APÊNDICE P. As amostras depois de coletadas eram mantidas em recipiente de isopor, durante período de 24 horas, para promover a homogeneização da temperatura e enviadas ao laboratório da ETA, Estação de Tratamento de Água, de Novo Horizonte, SP onde era medida a concentração do corante em cada amostra.

As amostras foram retiradas na superfície $(0,0 \mathrm{~cm})$ e nas profundidades de $30 \mathrm{~cm}$, $60 \mathrm{~cm}$ e $90 \mathrm{~cm}$, em vários pontos conforme cada experimento, e no efluente. As coletas na coluna d'água eram realizadas diariamente em torno das 16:00 horas e no efluente a cada quatro horas até que se obtivesse quatro amostras com concentração de Rodamina abaixo de $1 \mu \mathrm{g} / \mathrm{l}$, momento no qual o experimento era encerrado. Com a utilização de aparelho medidor da fluorescência essas concentrações puderam ser estabelecidas. O fluorômetro utilizado foi o modelo FM 109525 da marca TURNER QUANTECH (FIGURA 5.4). Nas mesmas amostras foram realizadas análises de DQO de maneira a determinar a concentração de matéria orgânica na coluna d'água.

A análise qualitativa do escoamento foi feita a partir de gráficos com valores adimensionais $\mathrm{C} / \mathrm{Co}$ em função de $\mathrm{t} / \mathrm{tm}$, onde $\mathrm{C}$ é a concentração do traçador na saída em função do tempo, Co é a massa do traçador injetado dividida pelo volume útil da lagoa, t o tempo de decorrência do experimento, e tm o tempo de detenção hidráulico teórico. A análise quantitativa foi realizada a partir de gráficos com valores adimensionais $1-\mathrm{F}(\mathrm{t})$ em função de $\mathrm{t} / \mathrm{tm}$, onde $1-\mathrm{F}(\mathrm{t})$ é a porcentagem de traçador que permanece no interior da lagoa. 


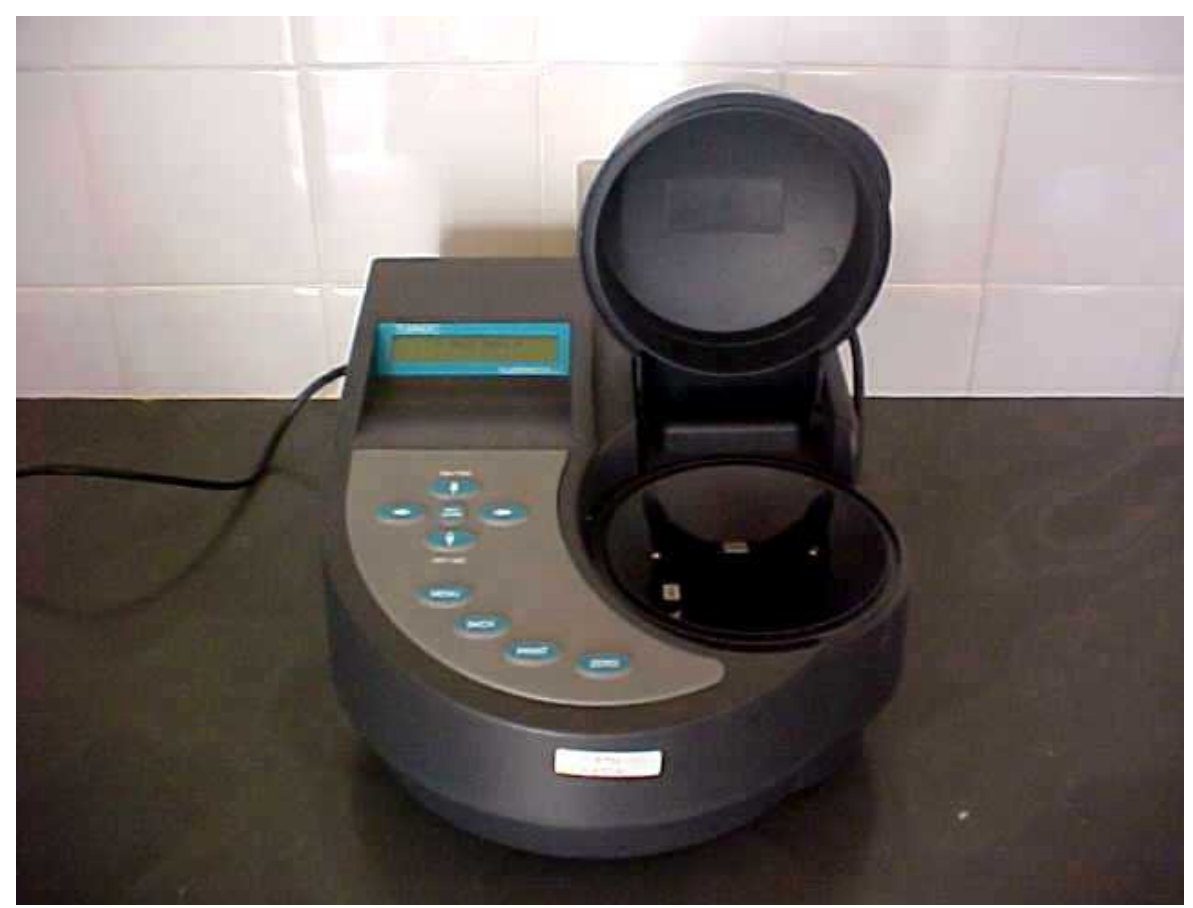

FIGURA 5.4 - Fluorômetro utilizado na pesquisa - modelo FM 109525 da marca TURNER QUANTECH.

\subsection{Resultados}

Os resultados são apresentados para as três diferentes configurações físicas da lagoa: lagoa sem chicaneamento (controle), lagoa com chicaneamento longitudinal e lagoa com chicaneamento longitudinal e transversal, sendo que no item 5.4.2.4 foi feita a comparação entre os resultados de maneira a verificar qual sistema apresentava melhor desempenho hidrodinâmico com relação a TDH real, Numero de Dispersão (d), espaço morto e volume ativo.

\subsubsection{Lagoa sem chicaneamento (controle)}

A lagoa sem chicaneamento foi operada conforme FIGURA 5.5 e 5.6 sendo que os dispositivos de entrada e saída foram posicionados no centro da lagoa e ambos a 30 $\mathrm{cm}$ de profundidade. 


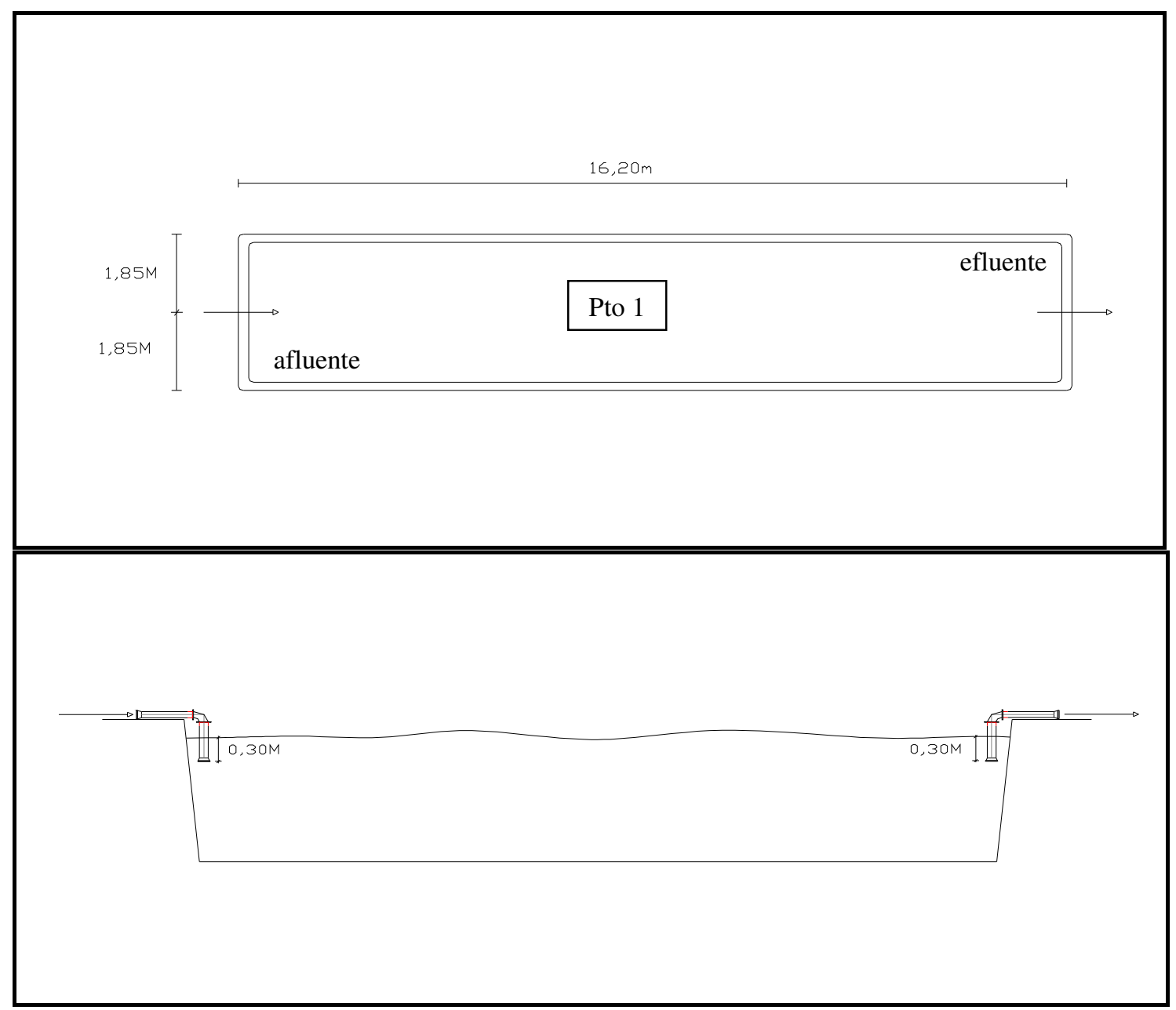

FIGURA 5.5 - Detalhes dimensionais da lagoa sem chicaneamento - Dimensões gerais e detalhe dos dispositivos de entrada e saída.

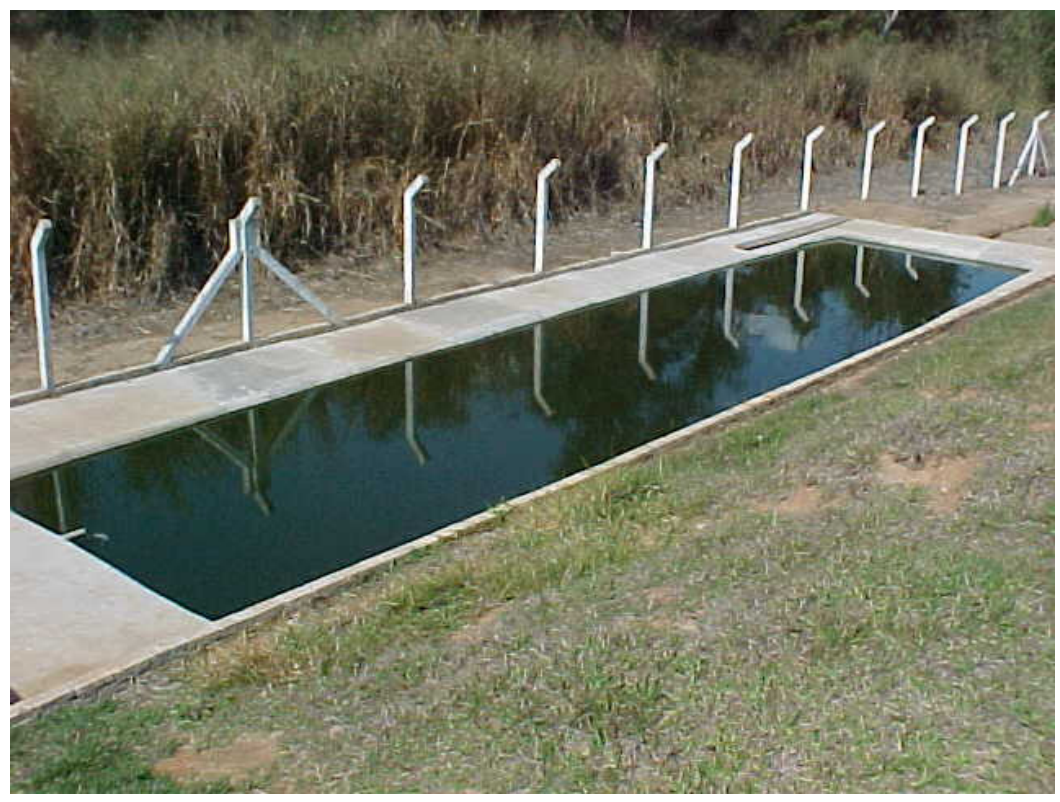

FIGURA 5.6 - Vista geral da lagoa sem chicaneamento. 
A vazão média desse experimento era de $0,22 \mathrm{~m}^{3} / \mathrm{h}$, sendo os dados de entrada e as medidas de concentração de Rodamina apresentados na TABELA 5.3.

TABELA 5.3 - Condições básicas da operação da lagoa sem chicaneamento e resultados de análise de amostras do traçador no efluente do sistema.

\begin{tabular}{|c|c|c|c|c|c|}
\hline \multicolumn{6}{|c|}{ Caracterização Hidrodinâmica de Lagoas } \\
\hline & $\begin{array}{l}\text { DADOS DE EN } \\
\text { Data do ensaio } \\
\text { Sistema de Trata } \\
\text { Volume da Lago } \\
\text { Vazão média }\left(\mathrm{m}^{3}\right. \\
\text { Concentração da } \\
\text { Volume de Roda } \\
\text { Concentração de }\end{array}$ & $\begin{array}{l}\text { RDA } \\
\text { ento } \\
\left.\mathrm{m}^{3}\right) \\
\text { odamina }(\mathrm{g} / \mathrm{l}) \\
\text { ina injetado }(\mathrm{ml}) \\
\text { odamina }\left(\mathrm{C}_{0}\right)(\mu \mathrm{g} / \mathrm{l})\end{array}$ & $\begin{array}{c}\text { Inicial: } 01 / 11 / 2002 \\
\text { lagoa sem chicanas } \\
36,9 \\
0,22 \\
200 \\
10 \\
54\end{array}$ & & Final:11/11/2002 \\
\hline \multicolumn{6}{|c|}{ Pares de dados do ensaio com traçador } \\
\hline $\mathrm{N}^{\mathrm{o}}$ da amostra & $\begin{array}{c}\text { Tempo } \\
\text { ( Ti )(horas) }\end{array}$ & $\begin{array}{c}\text { Concentração obtida } \\
(\mathrm{Ci})(\mu \mathrm{g} / \mathrm{l})\end{array}$ & $\mathrm{N}^{\mathrm{o}}$ da amostra & $\begin{array}{c}\text { Tempo } \\
\text { (Ti )(horas) }\end{array}$ & $\begin{array}{c}\text { Concentração obtida } \\
\begin{array}{l}(\mathrm{Ce})(\mu \mathrm{g} / \mathrm{l})\end{array}\end{array}$ \\
\hline 1 & & 0 & 30 & 114 & 17,3 \\
\hline 2 & 4 & 84,7 & 31 & 118 & 16,39 \\
\hline 3 & 8 & 78,1 & 32 & 122 & 16,3 \\
\hline 4 & 12 & 78,04 & 33 & 126 & 15,61 \\
\hline 5 & 16 & 68,3 & 34 & 130 & 11 \\
\hline 6 & 20 & 67,08 & 35 & 134 & 12,6 \\
\hline 7 & 24 & 59,1 & 36 & 138 & 10,7 \\
\hline 8 & 28 & 58,6 & 37 & 142 & 10,13 \\
\hline 9 & 32 & 53 & 38 & 146 & 9,3 \\
\hline 10 & 36 & 53,2 & 39 & 150 & 11,34 \\
\hline 11 & 40 & 46,6 & 40 & 154 & 8,9 \\
\hline 12 & 44 & 46,31 & 41 & 158 & 8,15 \\
\hline 13 & 48 & 53,02 & 42 & 162 & 5,3 \\
\hline 14 & 52 & 59,8 & 43 & 166 & 4 \\
\hline 15 & 56 & 58,1 & 44 & 170 & 4,50 \\
\hline 16 & 60 & 50,1 & 45 & 174 & 3,80 \\
\hline 17 & 64 & 49 & 46 & 178 & 2,30 \\
\hline 18 & 68 & 48,3 & 47 & 182 & 0,98 \\
\hline 19 & 72 & 48 & 48 & 186 & 1,02 \\
\hline 20 & 76 & 49,86 & 49 & 190 & 0,30 \\
\hline 21 & 80 & 49,5 & 50 & 194 & 0,00 \\
\hline 22 & 84 & 49,56 & 51 & 198 & 0,32 \\
\hline 23 & 88 & 32 & 52 & 202 & 0,00 \\
\hline 24 & 92 & 31,1 & 53 & 206 & 0,00 \\
\hline 25 & 96 & 24,2 & 54 & 210 & 0,25 \\
\hline 26 & 100 & 23 & 55 & 214 & 0,00 \\
\hline 27 & 104 & 21,69 & 56 & 218 & 0,00 \\
\hline 28 & 108 & 21,5 & 57 & 222 & 0,00 \\
\hline 29 & 112 & 18,68 & 58 & 226 & 0,00 \\
\hline
\end{tabular}


- Análise qualitativa do escoamento

Analisando a FIGURA 5.7 verifica-se que a discrepância entre o tempo de detenção hidráulico teórico de 169 horas e o tempo de detenção hidráulico real de 57,4 horas fornece evidência de zona morta e curto-circuito na lagoa. $\mathrm{O}$ pico de concentração obtido no efluente ocorreu em tempo menor que $10 \%$ do tempo de detenção hidráulico teórico, portanto conclui-se que houve curto-circuito na lagoa.

A presença de espaço morto na lagoa é caracterizada pela cauda, que aparece no final da FIGURA 5.7, por mais de 1,5 vezes o tempo de detenção hidráulico teórico.

A pequena porcentagem de volume ativo, em torno de $34 \%$ do volume total da lagoa, mostra que o sistema possui baixa eficiência hidráulica, consequiência do elevado grau de estratificação que estava submetido, conforme se verifica pelos gráficos da FIGURA 5.9.

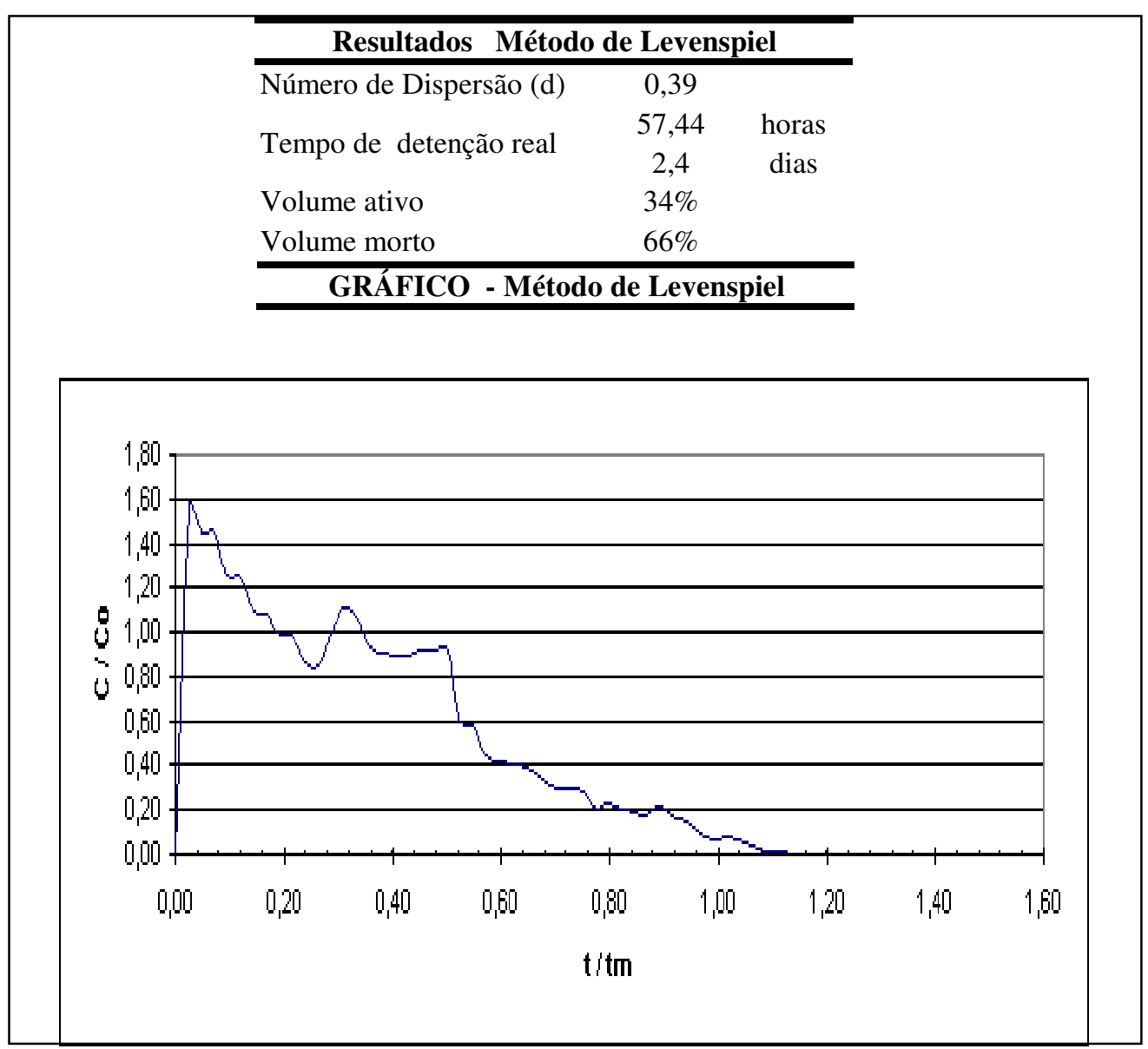

FIGURA 5.7 - Análise qualitativa do escoamento hídrico para lagoa sem chicaneamento 
- Análise quantitativa do escoamento

$\mathrm{Na}$ analise qualitativa, FIGURA 5.8, conforme método gráfico proposto por REBHUN e ARGAMAN (1965) conclui-se que $11 \%$ da lagoa estava operando em regime de escoamento pistonado e $23 \%$ em mistura completa, o que caracteriza um escoamento em regime não ideal .

Ocorreu a passagem de aproximadamente $80 \%$ do traçador no tempo relativo a $50 \%$ do tempo de detenção hidráulico teórico evidenciando curto-circuito na lagoa.

A cauda prolongada é um sintoma, que somado às demais análises anteriores, confirma a presença de espaços mortos.

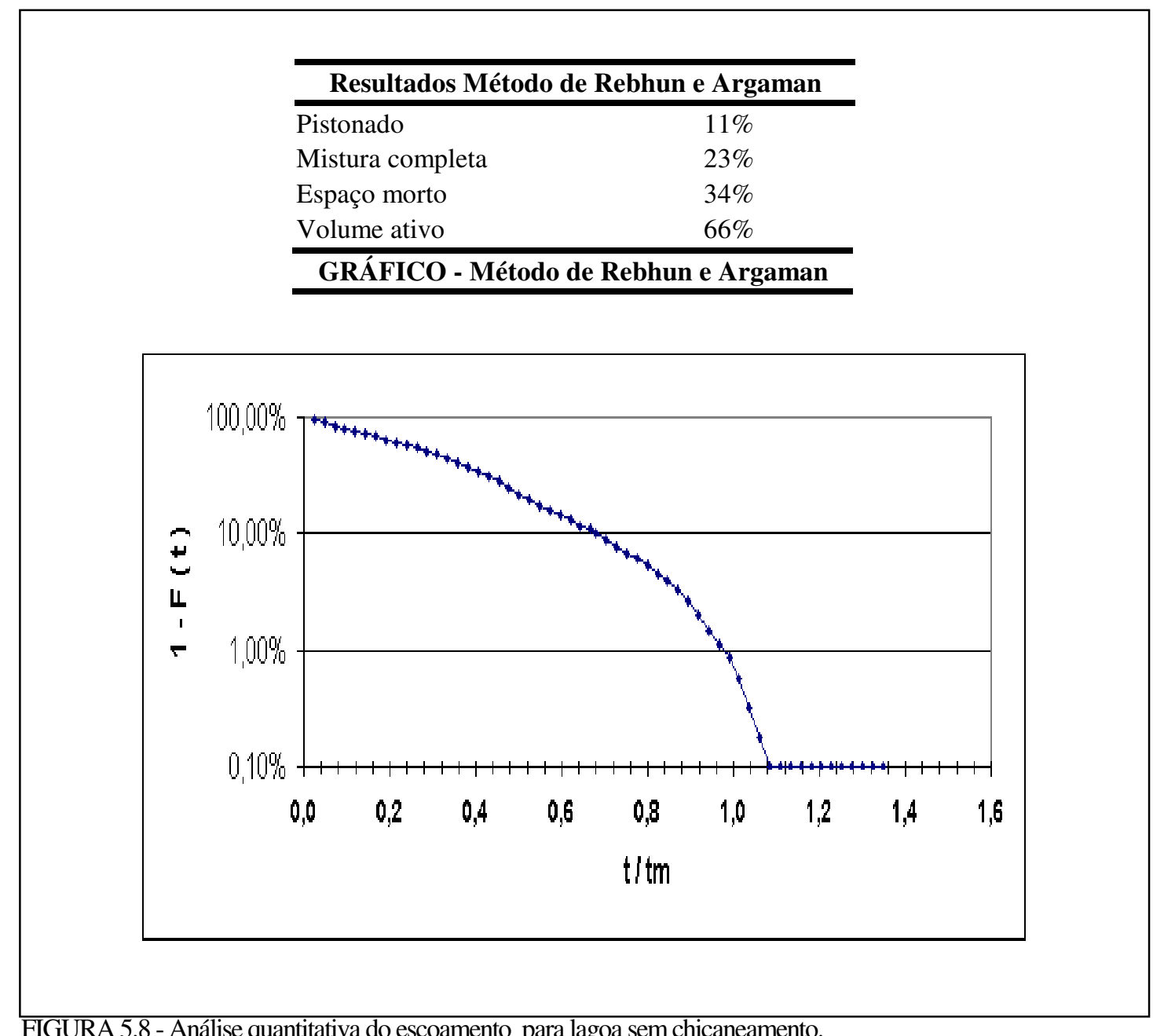

FIGURA 5.8 - Análise quantitativa do escoamento para lagoa sem chicaneamento.

- Perfil de temperatura e oxigênio dissolvido 
A FIGURA 5.9 e os APÊNDICES G e H caracterizam a região da termoclina entre a superfície e a profundidade de $30 \mathrm{~cm}$ com a queda de temperatura, entre esses extremos, de aproximadamente $7^{\circ} \mathrm{C}$.

A temperatura ambiente e elevada insolação, características da região de estudo, eram responsáveis por impor elevado grau de estratificação térmica da lagoa.

Na superfície o nível de oxigênio estava acima da saturação e abaixo de $60 \mathrm{~cm}$ de profundidade havia baixa concentração de OD, impondo a partir desse ponto condição de anaerobiose (ver APÊNDICE H ).

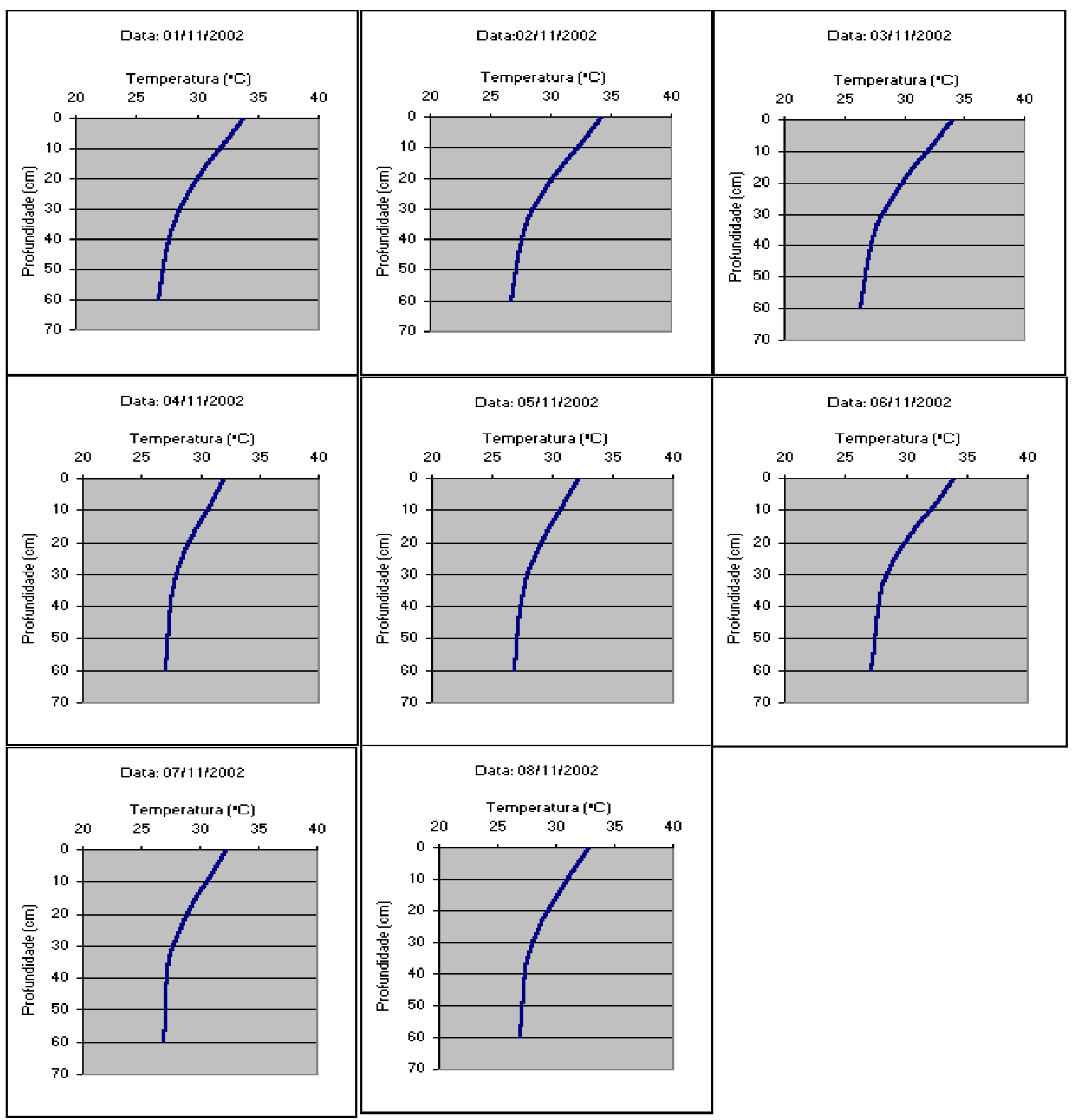

FIGURA 5.9 - Perfis de temperatura obtidos na lagoa sem chicaneamento ao longo do período de análise hidrodinâmica. Medidas às 16 horas de cada dia. Valores médios do ponto central da lagoa conforme FIGURA 5.5. 


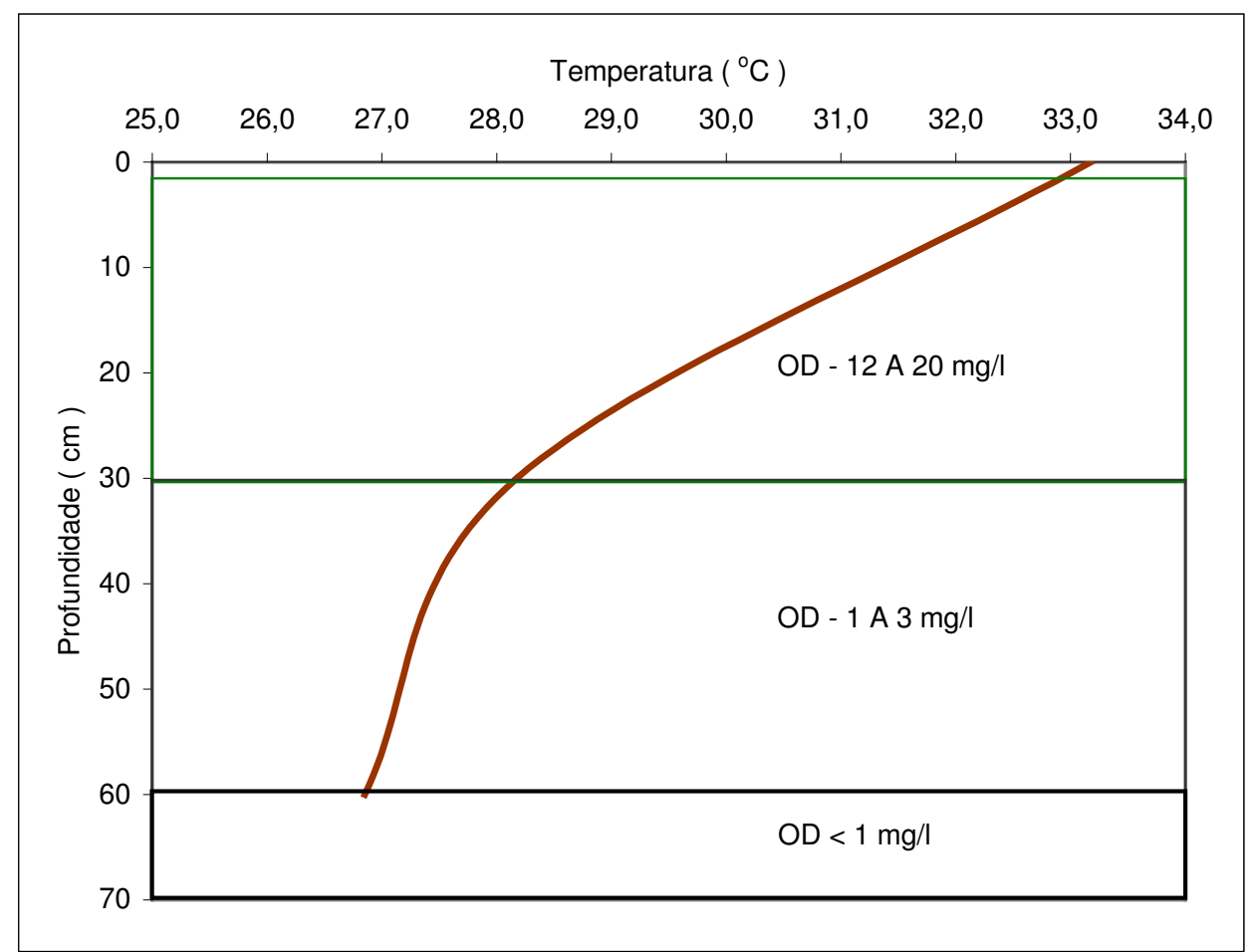

FIGURA 5.10 - Perfis de temperatura e concentração de oxigênio dissolvido obtidos na lagoa sem chicaneamento ao longo do período de análise hidrodinâmica. Medidas às 16 horas de cada dia. Valores médios entre os dias 1/11/2002 e 11/11/2002 no ponto central da lagoa

- Movimento e renovação do fluido na lagoa

A FIGURA 5.11 e APÊNDICES I e J mostram que a concentração de DQO era maior, para todas as medidas realizadas na coluna d'água, entre as profundidades de 30 $\mathrm{cm}$ e $40 \mathrm{~cm}$, sugerindo que predominante o escoamento encontrava-se nesta região. As concentrações de Rodamina ao longo da coluna d'água confirmam que ocorreu maior renovação do fluido na camada intermediária provocando maior diluição nessa região diminuindo a concentração do corante. 


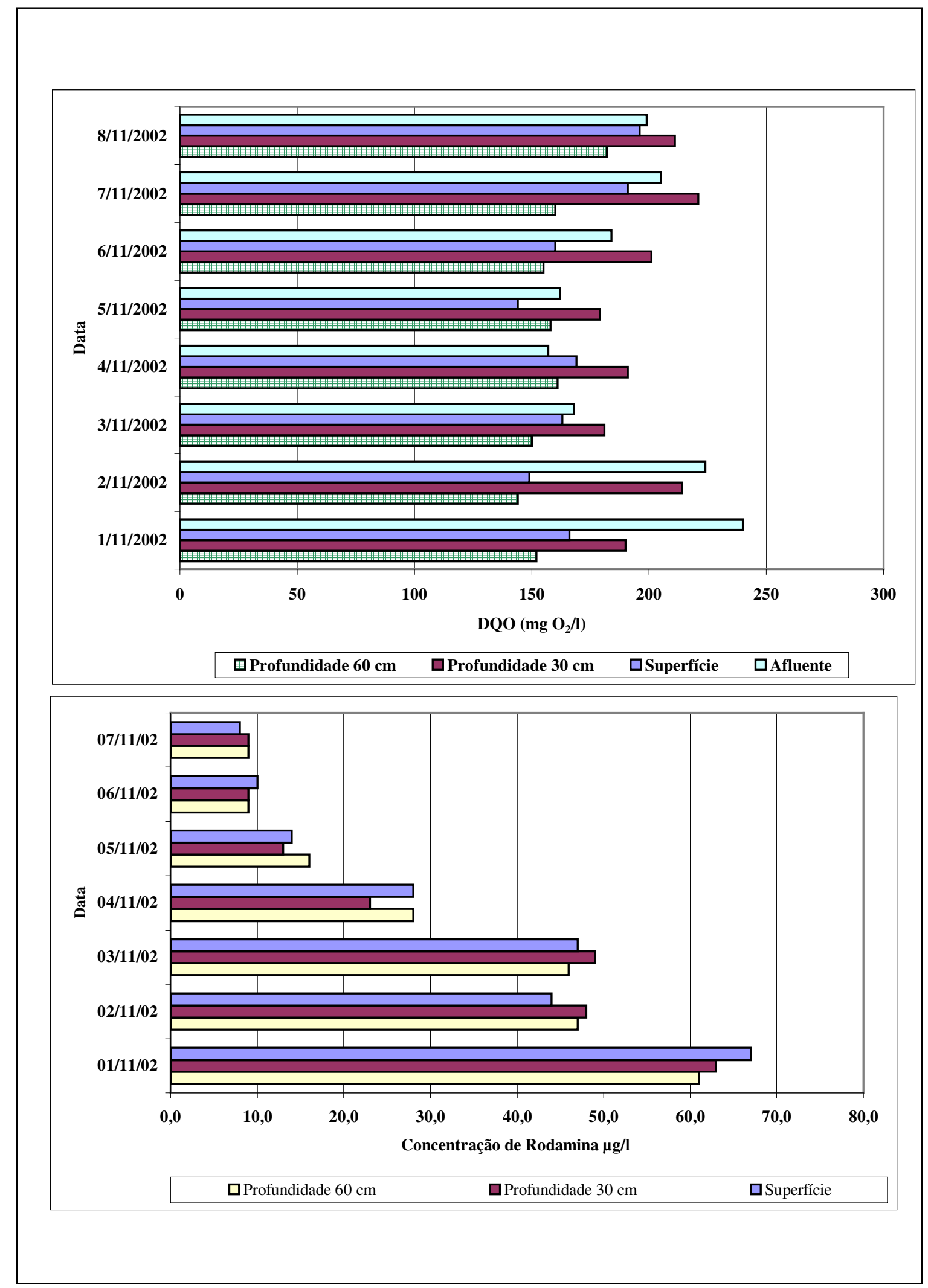

FIGURA 5.11 - Variação da concentração de DQO e corante obtidos na lagoa sem chicaneamento ao longo do período de análise hidrodinâmica. Medidas às 16 horas de cada dia. Amostras retiradas no ponto central da lagoa. 


\subsubsection{Chicaneamento longitudinal}

$\mathrm{Na}$ lagoa piloto foram introduzidas chicanas longitudinais conforme FIGURAS 5.12 e 5.13 .

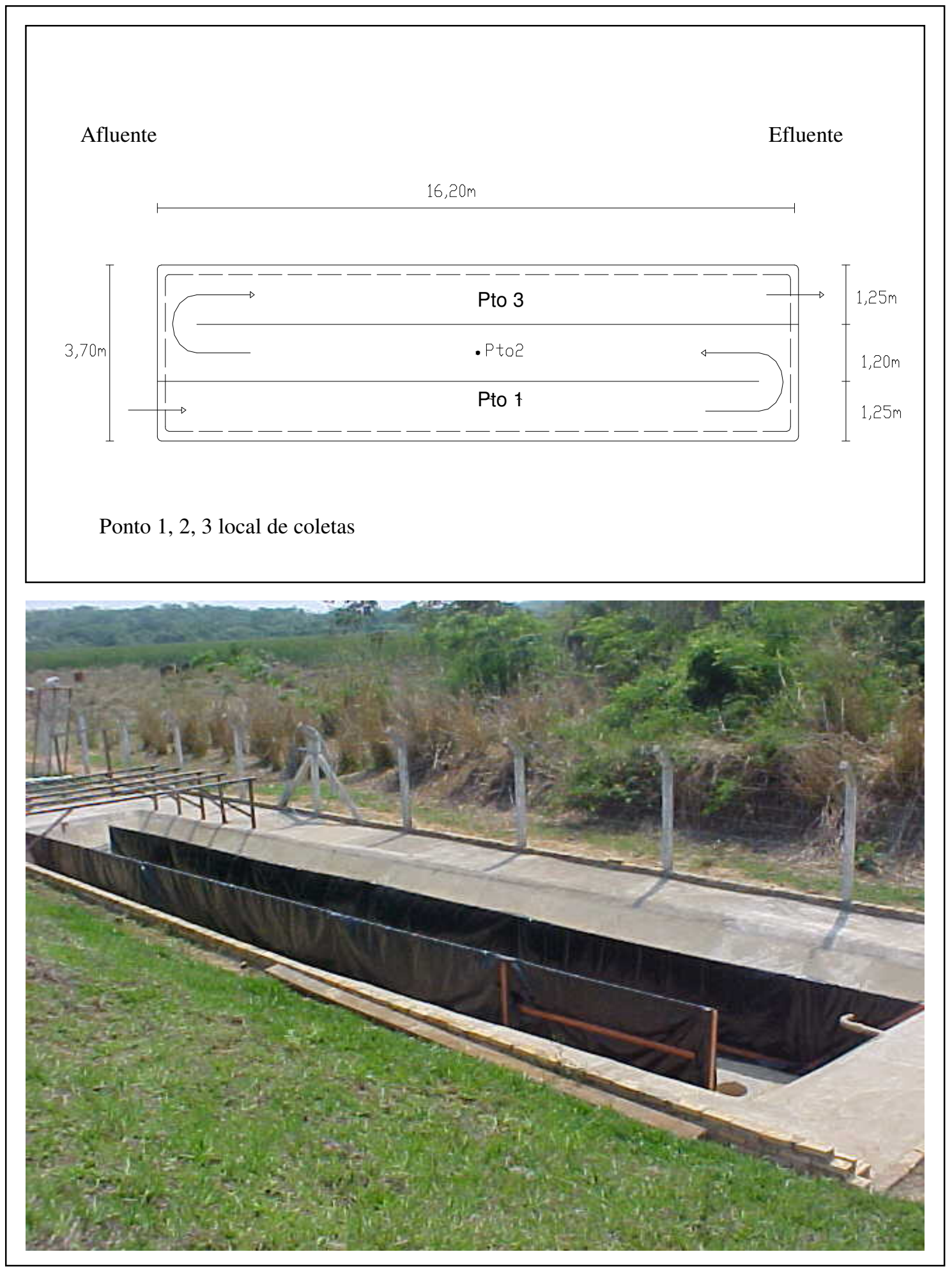

FIGURA 5.12 - Detalhes dimensionais da lagoa com chicanas longitudinais e foto do chicaneamento longitudinal. 


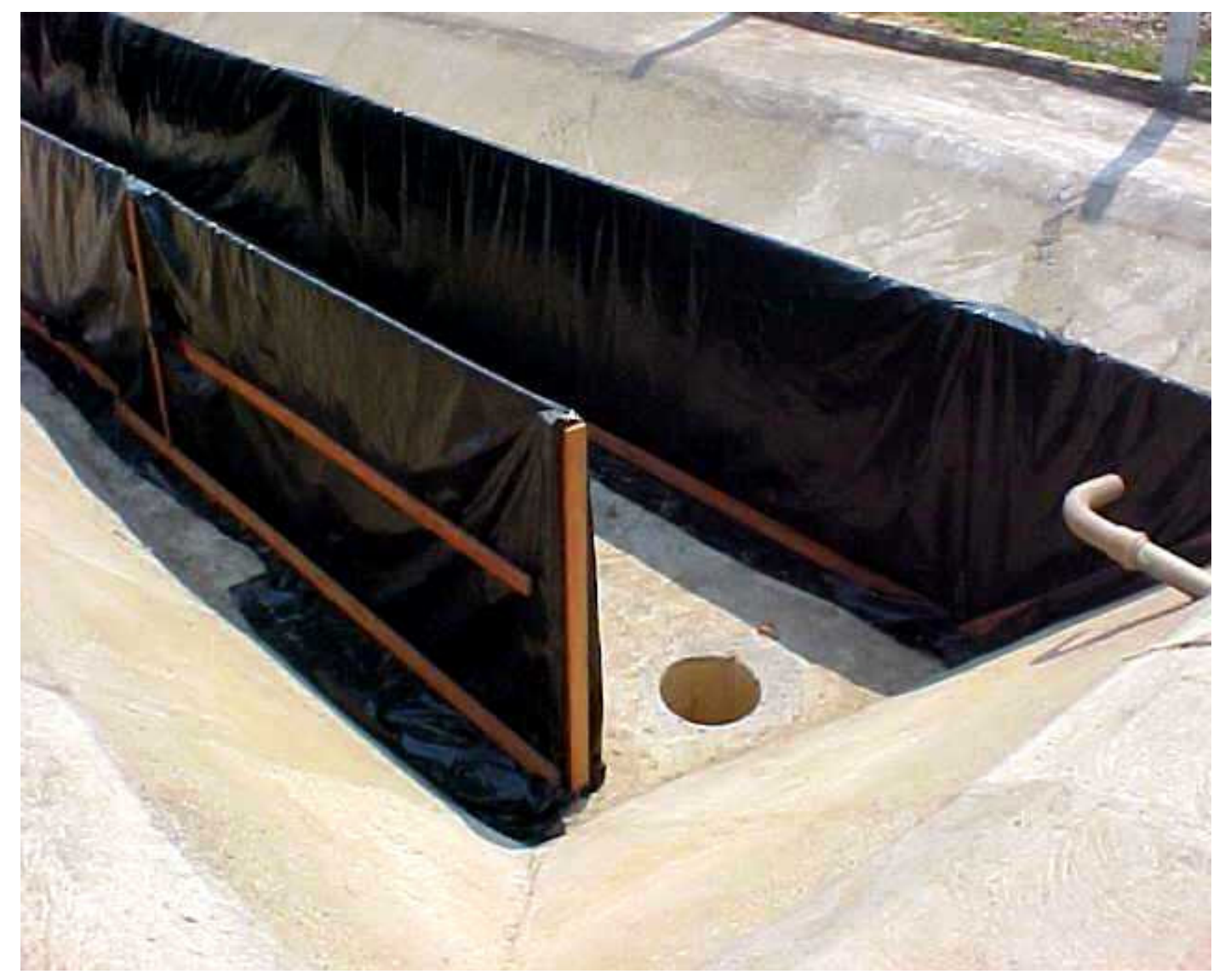

FIGURA 5.13 - Detalhe da construção das chicanas longitudinais.

O esgoto entrou a $30 \mathrm{~cm}$ da superfície e o dispositivo de saída retirou o efluente na mesma profundidade, sendo que a entrada situa-se no centro do primeiro compartimento e a saída no centro do terceiro compartimento. A entrada e saída do escoamento eram constantes, sendo que a média de vazão durante o período de ensaio era de $0,30 \mathrm{~m}^{3} / \mathrm{h}$.

A TABELA 5.4 demonstra as condições básicas do ensaio e mostra os pares de dados, tempo e concentração do traçador, no experimento realizado na lagoa com chicaneamento longitudinal. 
TABELA 5.4 - Condições básicas da operação da lagoa com chicaneamento longitudinal e resultados de análise de amostras do traçador no efluente do sistema. Amostras coletadas no efluente da lagoa.

\begin{tabular}{|c|c|c|c|c|c|}
\hline \multicolumn{6}{|c|}{ Caracterização Hidrodinamica de Lagoas } \\
\hline & $\begin{array}{l}\text { DADOS DE } \\
\text { Data do ensa } \\
\text { Sistema de T } \\
\text { Volume da L } \\
\text { Vazão média } \\
\text { Concentraçã } \\
\text { Volume de R } \\
\text { Concentraçã } \\
\end{array}$ & $\begin{array}{l}\text { NTRADA } \\
\text { tamento } \\
\text { goa }\left(\mathrm{m}^{3}\right) \\
\left.\mathrm{m}^{3} / \mathrm{h}\right) \\
\text { da Rodamina }(\mathrm{g} / \mathrm{l}) \\
\text { damina injetado }(\mathrm{ml}) \\
\text { da Rodamina }\left(\mathrm{C}_{0}\right)(\mu \mathrm{g} / \mathrm{l})\end{array}$ & $\begin{array}{c}\text { Inicial } 09 / 12 \\
\text { lagoa com ch } \\
36,9 \\
0,3 \\
200 \\
10 \\
54 \\
\end{array}$ & $\begin{array}{l}01 \\
\text { na longitudinal }\end{array}$ & Final 19/12/2001 \\
\hline \multicolumn{6}{|c|}{ Pares de dados do ensaio com traçador } \\
\hline $\begin{array}{l}\mathrm{N}^{\circ} \mathrm{da} \\
\text { amostra }\end{array}$ & $\begin{array}{c}\text { Tempo } \\
\text { (Ti )(horas) }\end{array}$ & $\begin{array}{l}\text { Concentração obtida } \\
(\mathrm{Ci})(\mu \mathrm{g} / \mathrm{l})\end{array}$ & $\begin{array}{c}\mathrm{N}^{\circ} \mathrm{da} \\
\text { amostra }\end{array}$ & $\begin{array}{c}\text { Tempo } \\
\text { (Ti )(horas) }\end{array}$ & $\begin{array}{l}\text { Concentração obtida } \\
(\mathrm{Ci})(\mu \mathrm{g} / \mathrm{l})\end{array}$ \\
\hline 1 & 0 & 0,0 & 30 & 114 & 29,9 \\
\hline 2 & 4 & 1,5 & 31 & 118 & 23,3 \\
\hline 3 & 8 & 42,7 & 32 & 122 & 16,7 \\
\hline 4 & 12 & 34,4 & 33 & 126 & 19,5 \\
\hline 5 & 16 & 45,5 & 34 & 130 & 18,9 \\
\hline 6 & 20 & 48,3 & 35 & 134 & 17,9 \\
\hline 7 & 24 & 62,5 & 36 & 138 & 18,1 \\
\hline 8 & 28 & 61,6 & 37 & 142 & 15,3 \\
\hline 9 & 32 & 62,3 & 38 & 146 & 11,3 \\
\hline 10 & 36 & 57,5 & 39 & 150 & 14,8 \\
\hline 11 & 40 & 55,8 & 40 & 154 & 9,9 \\
\hline 12 & 44 & 52,2 & 41 & 158 & 11,9 \\
\hline 13 & 48 & 59,7 & 42 & 162 & 3,8 \\
\hline 14 & 52 & 60,5 & 43 & 166 & 2,7 \\
\hline 15 & 56 & 57,3 & 44 & 170 & 2,4 \\
\hline 16 & 60 & 57,1 & 45 & 174 & 2,4 \\
\hline 17 & 64 & 57,3 & 46 & 178 & 4,9 \\
\hline 18 & 68 & 44,7 & 47 & 182 & 0,5 \\
\hline 19 & 72 & 42,4 & 48 & 186 & 1,0 \\
\hline 20 & 76 & 38,7 & 49 & 190 & 0,4 \\
\hline 21 & 80 & 30,5 & 50 & 194 & 1,9 \\
\hline 22 & 84 & 34,3 & 51 & 198 & 0,5 \\
\hline 23 & 88 & 33,3 & 52 & 202 & 1,9 \\
\hline 24 & 92 & 32,1 & 53 & 206 & 0,7 \\
\hline 25 & 96 & 27,5 & 54 & 210 & 1,0 \\
\hline 26 & 100 & 23,1 & 55 & 214 & 0,7 \\
\hline 27 & 104 & 26,8 & 56 & 218 & 0,3 \\
\hline 28 & 108 & 29,3 & 57 & 222 & 0,3 \\
\hline 29 & 112 & 30,1 & 58 & 226 & 0,0 \\
\hline
\end{tabular}

- Analise qualitativa do escoamento 
A análise qualitativa do escoamento foi realizada conforme modelo estatístico proposto por LEVENSPIEL (1979), descrito na secção 5.3.1, determinando-se o Número de Dispersão (d), porcentagem de volume ativo, porcentagem de volume morto e tempo de detenção hidráulico real. Os resultados são apresentados na FIGURA 5.14.

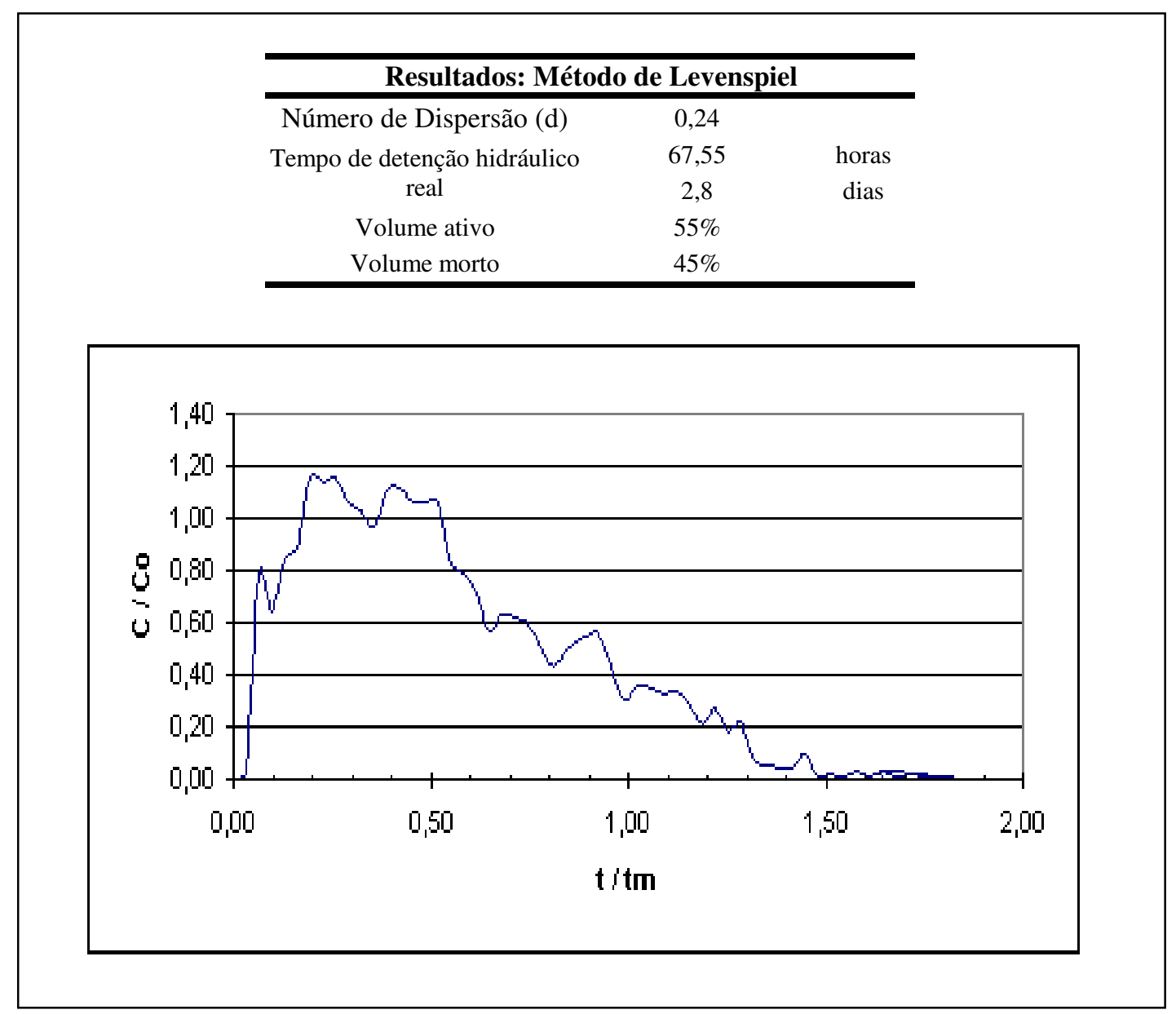

FIGURA 5.14 - Análise qualitativa do escoamento para lagoa com chicaneamento longitudinal.

A curva que representa a concentração do traçador $\mathrm{x}$ tempo indica que a zona ativa possuía características de elevado grau de dispersão com Número de Dispersão (d) igual a 0,24, pico bastante pronunciado no início do experimento e longa cauda, demonstrando curto-circuito e presença de espaços mortos.

O curto-circuito é ainda caracterizado pelos picos da FIGURA 5.14 que são maiores que 1 e aparecem antes de $\mathrm{t} / \mathrm{tm}=1$. 
O tempo real de residência do fluido no interior da lagoa foi de 67,5 horas, muito menor que o tempo teórico de residência de 123 horas, verificando-se assim que aproximadamente $55 \%$ do volume da lagoa estava ativo e $45 \%$ era de volume morto. Essa análise confirma elevado grau de estratificação no sistema (ver FIGURA 5.16).

- Análise quantitativa do escoamento (Método de REBHUN e ARGAMAN)

A curva 1-F(t), FIGURA 5.15, que representa a quantidade de traçador que permanece no interior do sistema, mostra que a lagoa possuía características de escoamento não ideal com predominância para regime em mistura completa com $33 \%$ contra $19 \%$ em regime pistonado.

A estratificação térmica e o curto-circuito fizeram com que $90 \%$ do traçador atingisse a saída do sistema no tempo igual ao tempo de detenção teórico. A cauda prolongada indica a presença de espaço morto na lagoa.

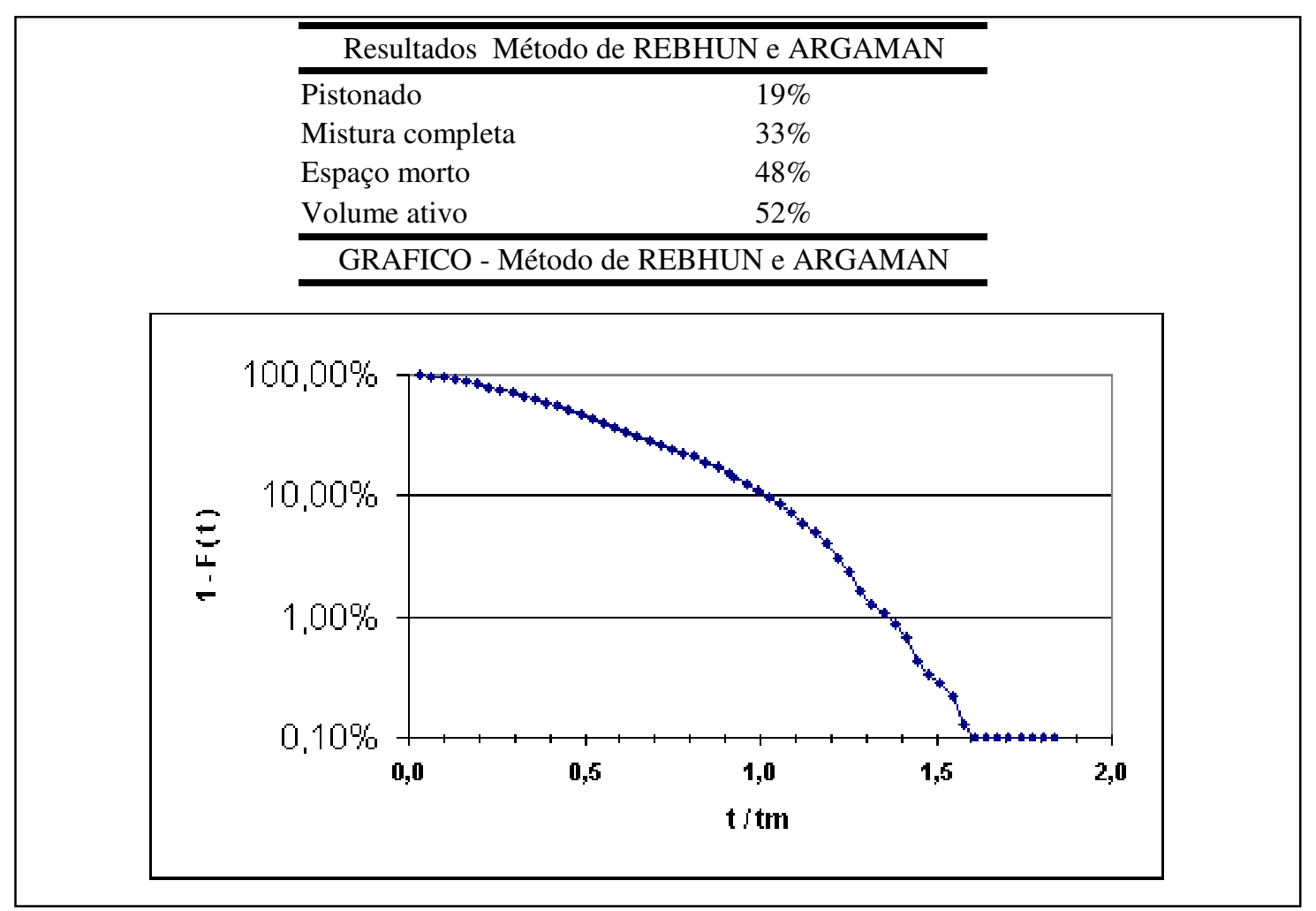

FIGURA 5.15 - Análise quantitativa do escoamento para lagoa com chicaneamento longitudinal. 
- Perfil de temperatura e oxigênio dissolvido

Os perfis de temperatura e oxigênio dissolvidos estão mostrados nas FIGURAS 5.16 e 5.17 e nos APÊNDICES K e L.

Ao longo do ensaio, a temperatura média (medida às 16:00h) na superfície do fluido era bastante elevada, superando os $34^{\circ} \mathrm{C}$, impondo elevado grau de estratificação ao sistema.

Ocorreu uma queda brusca de temperatura entre a superfície e a profundidade de $30 \mathrm{~cm}$ caracterizando essa camada como o epilímnio.

A concentração de oxigênio era mais elevada na camada superior, mais quente, e onde ocorre a penetração de luz, com valores muito acima dos valores de saturação a essa temperatura, superando $20 \mathrm{mg} \mathrm{O}_{2} / 1$

A curva de oxigênio demonstra que abaixo da termoclina ocorreu queda brusca na concentração de oxigênio com concentração menor que $1 \mathrm{mg} \mathrm{O} / 1$ abaixo de $60 \mathrm{~cm}$ de profundidade. 

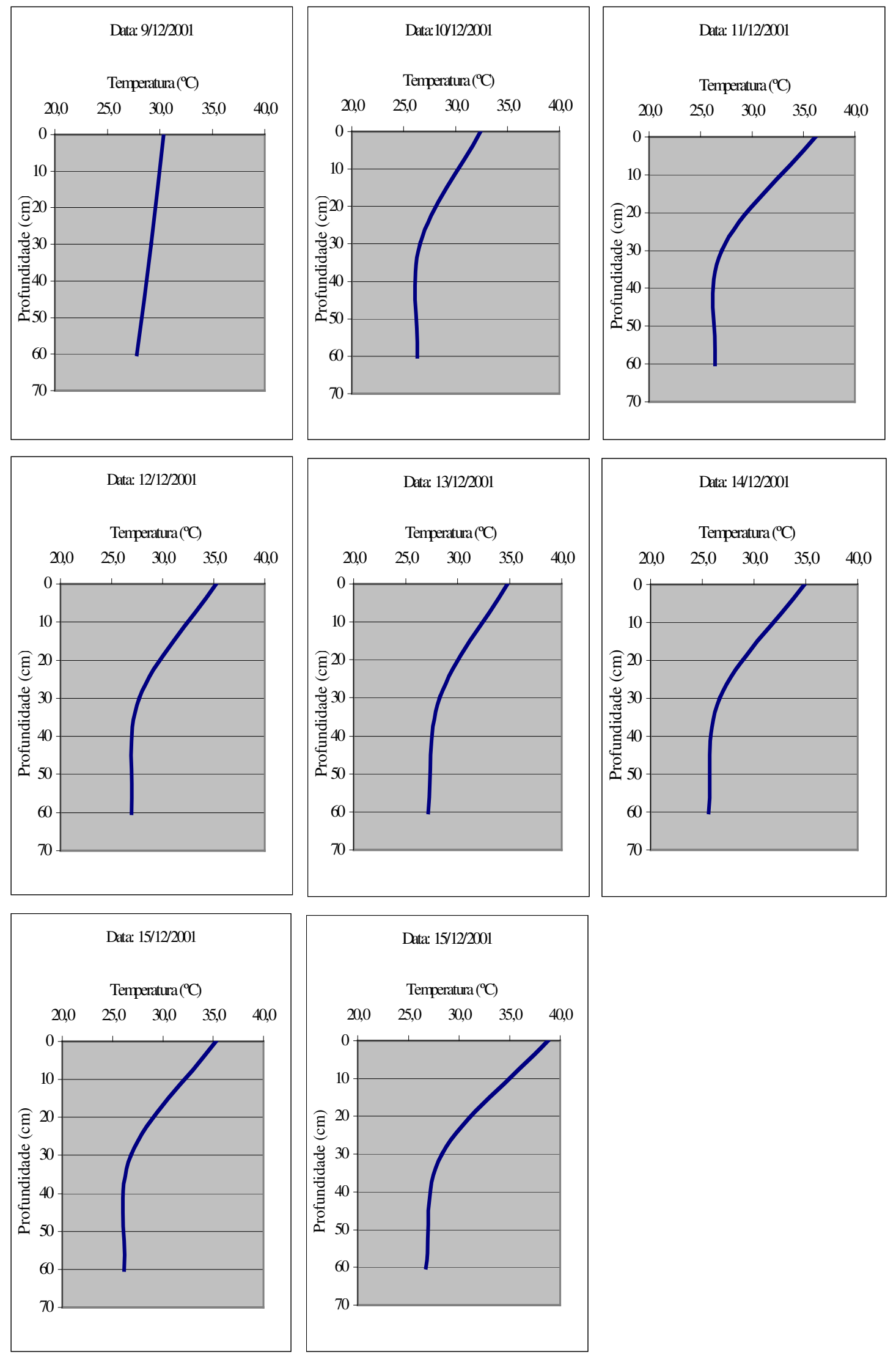

FIGURA 5.16 - Perfis de temperatura obtidos na lagoa com chicaneamento longitudinal ao longo do período de análise hidrodinâmica. Medidas às 16 horas de cada dia. Valores médios dos pontos 1,2 e 3 conforme FIGURA 5.12. 


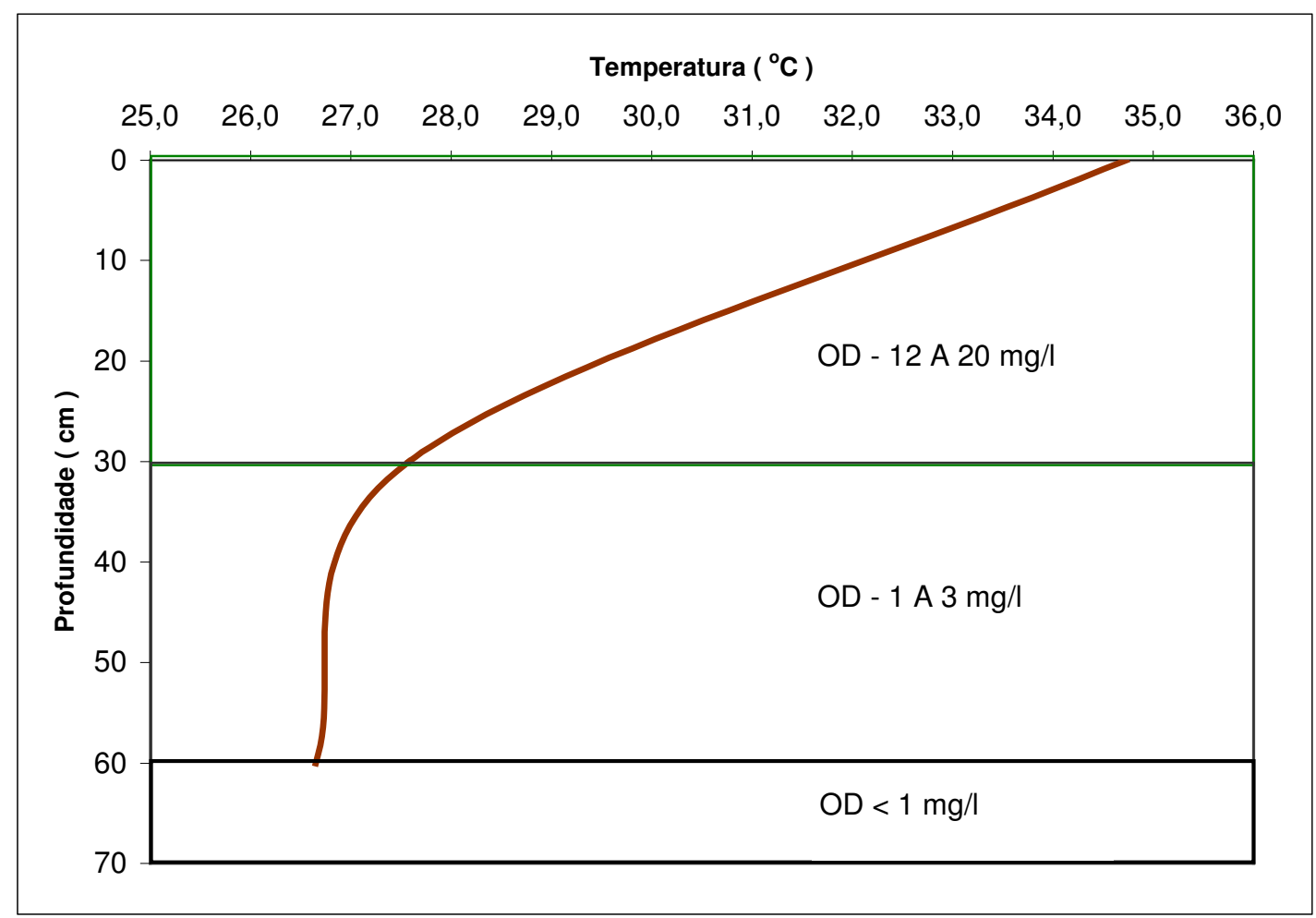

FIGURA 5.17 - Perfis de temperatura e concentração de oxigênio dissolvido obtido na lagoa com chicaneamento longitudinal ao longo do período de análise hidrodinâmica. Medidas às 16 horas de cada dia . Valores médios entre os dias 9/12/2001 e 16/12/2001 nos pontos 1,2 e 3 conforme FIGURA 5.12.

- Movimento e renovação do fluido na lagoa

A partir das análises de DQO e concentração do corante na coluna d'água determinou-se a posição de renovação e movimento do esgoto no interior da lagoa, ou seja, qual a camada ou profundidade que o efluente se acomodava durante o período em que ocorria o fenômeno de estratificação térmica. A FIGURA 5.18 e APÊNDICES M e $\mathrm{N}$ demonstram que para qualquer tempo as concentrações de DQO eram mais elevadas para a região entre $30 \mathrm{~cm}$ e $40 \mathrm{~cm}$ de profundidade, contrapondo com a concentração de corante que era menor para essa mesma faixa de profundidade, sinalizando que ocorria maior renovação do escoamento nesta região e, portanto escoamento preferencial. 


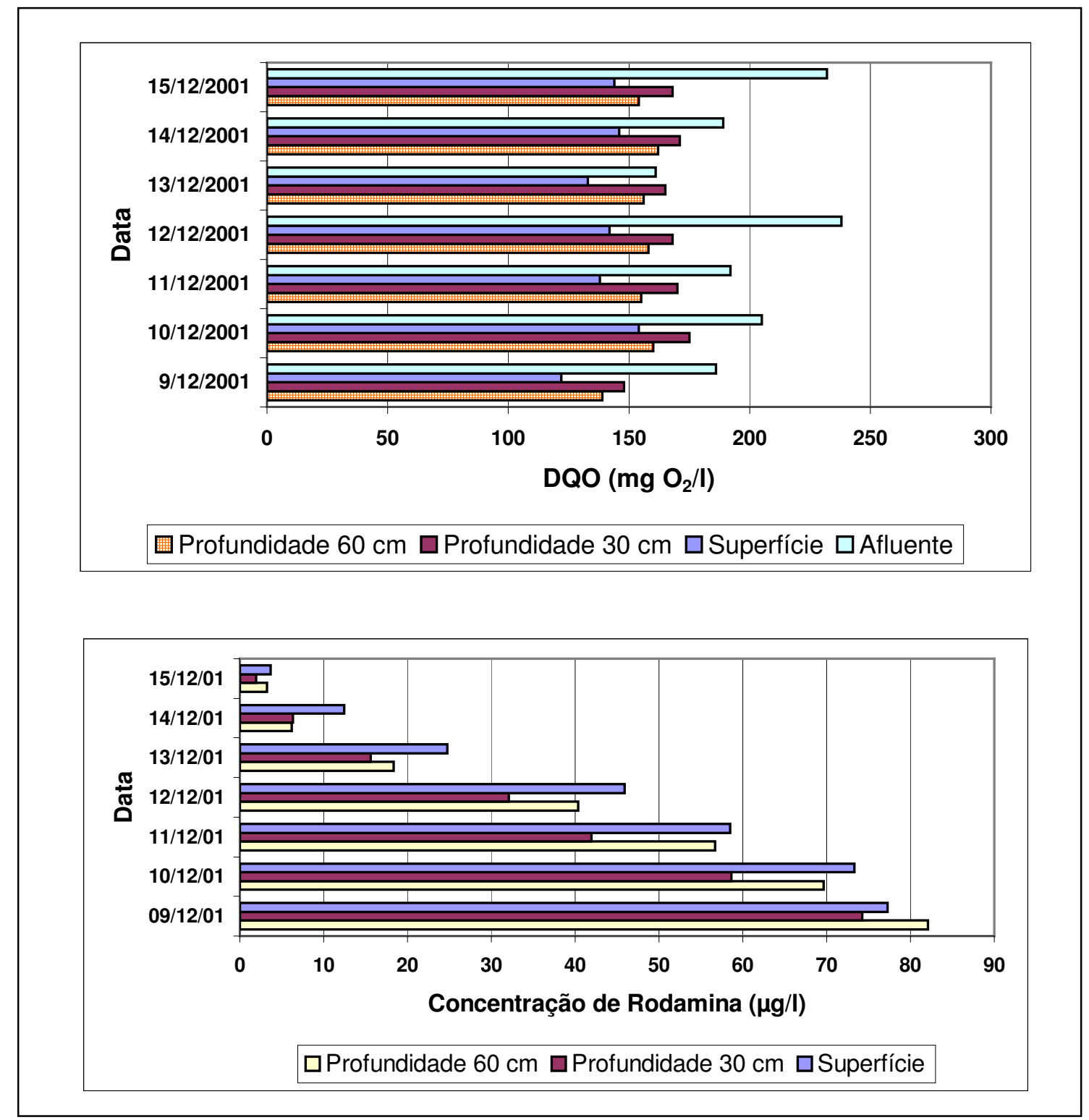

FIGURA 5.18 - Variação da concentração de DQO e corante obtidos na lagoa com chicaneamento longitudinal ao longo do período de análise hidrodinâmica. Medidas às 16 horas de cada dia. Corante: valores médios entre os dias 9/12/2001 e 16/12/2001 nos pontos 1,2 e 3. Os valores de DQO foram obtidos de amostras da retiradas no ponto 2.

\subsubsection{Chicaneamento longitudinal e transversal}

Tendo com o objetivo verificar o desempenho hidrodinâmico do sistema com chicanas longitudinais em conjunto com chicanas transversais foram inseridas, na lagoa, chicanas formando barreiras em pontos (ver FIGURAS 5.19 e 5.20 ). 

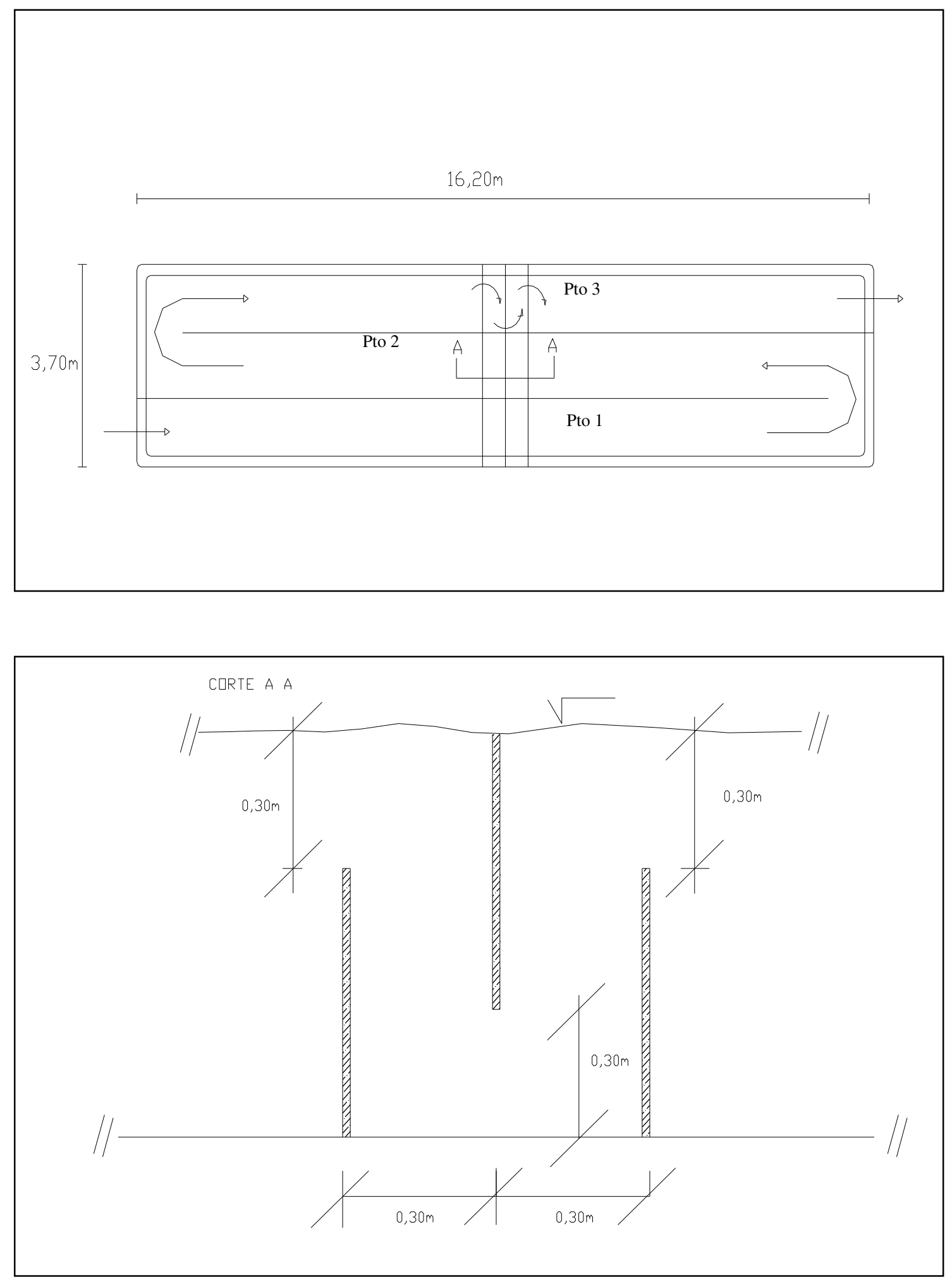

FIGURA 5.19 - Detalhes dimensionais da lagoa com chicanas longitudinais e transversais - Dimensões gerais e detalhe das chicanas transversais. 
Adotou-se, como nos demais experimentos, a entrada do esgoto a $30 \mathrm{~cm}$ de profundidade da superfície e a saída na mesma posição. O dispositivo afluente situava-se no centro do primeiro compartimento e o efluente no centro do terceiro compartimento.

As vazões de entrada e saída eram constantes e iguais, com valor médio de $0,30 \mathrm{~m}^{3} / \mathrm{h}$.

A TABELA 5.5 mostra os dados de entrada do experimento e pares de dados concentração do traçador $\mathrm{x}$ tempo obtidos nos ensaios. 
TABELA 5.5 - Condições básicas da operação da lagoa com chicaneamento longitudinal e transversal e resultados de análises de amostras do traçador no efluente do sistema.

\begin{tabular}{|c|c|c|c|c|c|}
\hline \multicolumn{6}{|c|}{ Caracterização Hidrodinâmica de Lagoas } \\
\hline & \multicolumn{5}{|c|}{ DADOS DE ENTRADA } \\
\hline & \multicolumn{2}{|l|}{ Data do ensaio } & Inicial & $25 / 06 / 2002$ & Final 05/07/2002 \\
\hline & \multicolumn{2}{|c|}{ Sistema de Tratamento } & \multicolumn{3}{|c|}{ lagoa com chicana transversal/longitudinal } \\
\hline & \multicolumn{2}{|c|}{ Volume da Lagoa $\left(\mathrm{m}^{3}\right)$} & \multicolumn{2}{|c|}{36,9} & \\
\hline & \multicolumn{2}{|l|}{ Vazão média $\left(\mathrm{m}^{3} / \mathrm{h}\right)$} & 0,3 & & \\
\hline & \multicolumn{2}{|c|}{ Concentração da Rodamina (g/l) } & 200 & & \\
\hline & \multicolumn{2}{|c|}{ Volume de Rodamina injetado (ml) } & 10 & & \\
\hline & \multicolumn{2}{|c|}{ Concentração de Rodamina $\left(\mathrm{C}_{0}\right)(\mu \mathrm{g} / \mathrm{l})$} & 54 & & \\
\hline \multicolumn{6}{|c|}{ Pares de dados do ensaio com traçador } \\
\hline $\begin{array}{c}\mathrm{N}^{\mathrm{o}} \mathrm{da} \\
\text { amostra }\end{array}$ & $\begin{array}{c}\text { Tempo } \\
\text { ( Ti )(horas) }\end{array}$ & $\begin{array}{l}\text { Concentração obtida } \\
(\mathrm{Ci})(\mu \mathrm{g} / \mathrm{l})\end{array}$ & $\begin{array}{c}\mathrm{N}^{\mathrm{o}} \mathrm{da} \\
\text { amostra }\end{array}$ & $\begin{array}{c}\text { Tempo } \\
\text { ( Ti )(horas) }\end{array}$ & $\begin{array}{c}\text { Concentração obtida } \\
(\mathrm{Ci})(\mu \mathrm{g} / \mathrm{l})\end{array}$ \\
\hline 1 & 0 & 0 & 30 & 114 & 5,3 \\
\hline 2 & 4 & 74,9 & 31 & 118 & 2,13 \\
\hline 3 & 8 & 73,6 & 32 & 122 & 2,6 \\
\hline 4 & 12 & 62,6 & 33 & 126 & 1,95 \\
\hline 5 & 16 & 63 & 34 & 130 & 1,32 \\
\hline 6 & 20 & 67 & 35 & 134 & 9,54 \\
\hline 7 & 24 & 65,8 & 36 & 138 & 3,5 \\
\hline 8 & 28 & 50,1 & 37 & 142 & 0,86 \\
\hline 9 & 32 & 48,3 & 38 & 146 & 0,1 \\
\hline 10 & 36 & 37,7 & 39 & 150 & 0,08 \\
\hline 11 & 40 & 39 & 40 & 154 & 0,1 \\
\hline 12 & 44 & 43,5 & 41 & 158 & 0,2 \\
\hline 13 & 48 & 41 & 42 & 162 & 0 \\
\hline 14 & 52 & 55,4 & 43 & 166 & 0 \\
\hline 15 & 56 & 38,1 & 44 & 170 & 2,13 \\
\hline 16 & 60 & 28,7 & 45 & 174 & 0,00 \\
\hline 17 & 64 & 32,3 & 46 & 178 & 0,00 \\
\hline 18 & 68 & 35,18 & 47 & 182 & 0,00 \\
\hline 19 & 72 & 34,3 & 48 & 186 & 0,00 \\
\hline 20 & 76 & 49,74 & 49 & 190 & 0,00 \\
\hline 21 & 80 & 36,4 & 50 & 194 & 0,00 \\
\hline 22 & 84 & 22,1 & 51 & 198 & 0,00 \\
\hline 23 & 88 & 29,3 & 52 & 202 & 0,00 \\
\hline 24 & 92 & 32,89 & 53 & 206 & 0,00 \\
\hline 25 & 96 & 15,79 & 54 & 210 & 0,00 \\
\hline 26 & 100 & 16,6 & 55 & 214 & 0,00 \\
\hline 27 & 104 & 17,9 & 56 & 218 & 0,00 \\
\hline 28 & 108 & 10,9 & 57 & 222 & 0,00 \\
\hline 29 & 112 & 8,75 & 58 & 226 & 0,00 \\
\hline
\end{tabular}


- Análise qualitativa do escoamento

Analisando a FIGURA 5.2.1, verifica-se que o diagrama C/Co x t/tm apresenta inúmeros picos, fato também observado por MARECOS DO MONTE \& MARA (1987) e MORENO (1990) realizando experimentos similares, fenômeno esse atribuído por LEVENSPIEL (1974) à recirculação do fluido no interior da lagoa.

O Número de Dispersão (d) de 0,36 demonstra que o escoamento possuía grande quantidade de dispersão.

A cauda prolongada caracteriza a presença de espaço morto. A ocorrência de picos, mesmo quando a concentração do traçador já se encontrava bastante reduzida, indica que parte do fluido ficava retido em alguns pontos da lagoa sendo liberado de modo cíclico.

Esse fato associado à elevada porcentagem de volume morto do sistema, que totalizou $62 \%$ do volume total, mostra que a chicana longitudinal e transversal promoveu zonas de estagnação junto às barreiras reduzindo a porcentagem de volume ativo do sistema (ver FIGURA 5.22).

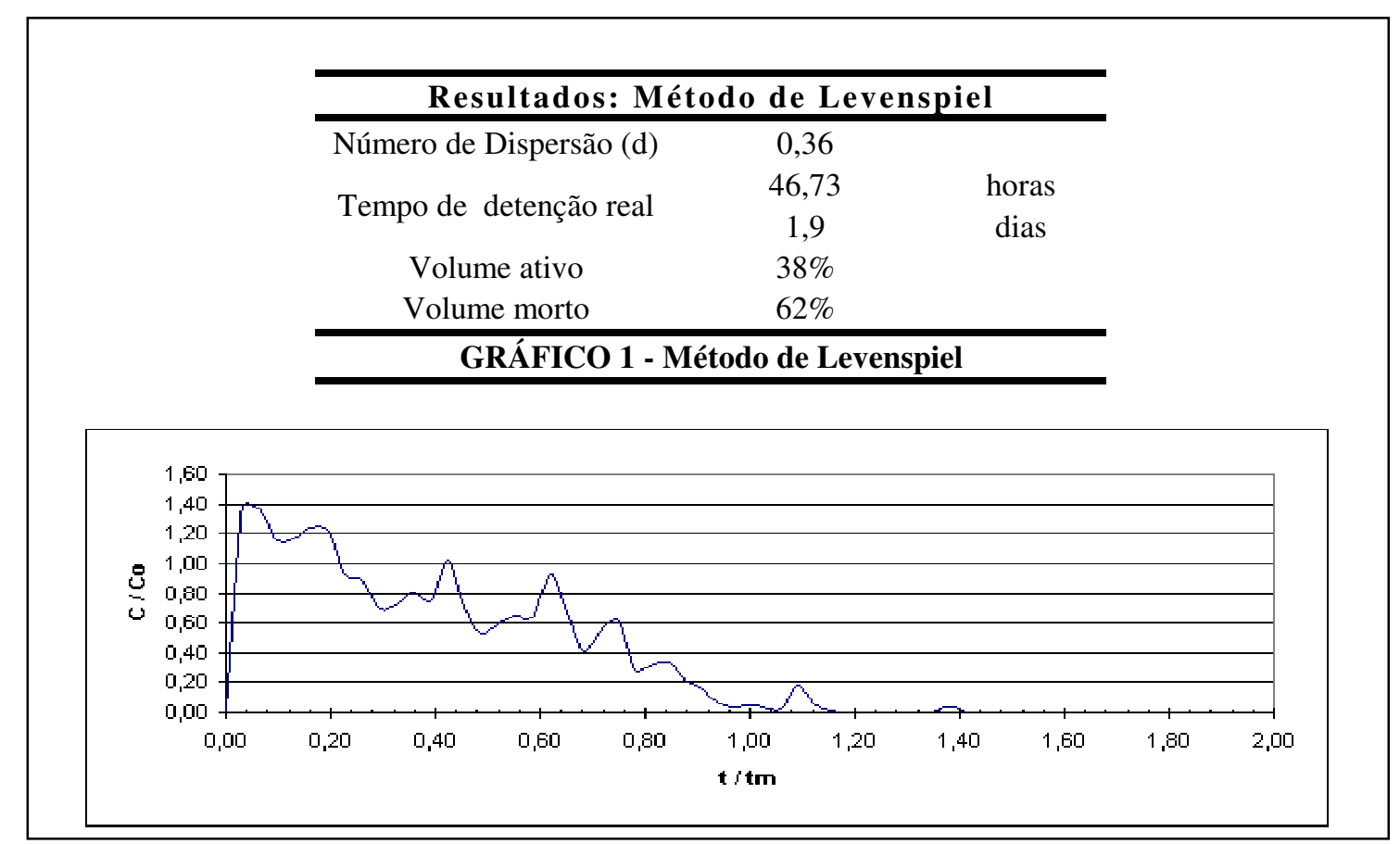

FIGURA 5.21 - Análise qualitativa do escoamento para lagoa com chicaneamento longitudinal e transversal. 


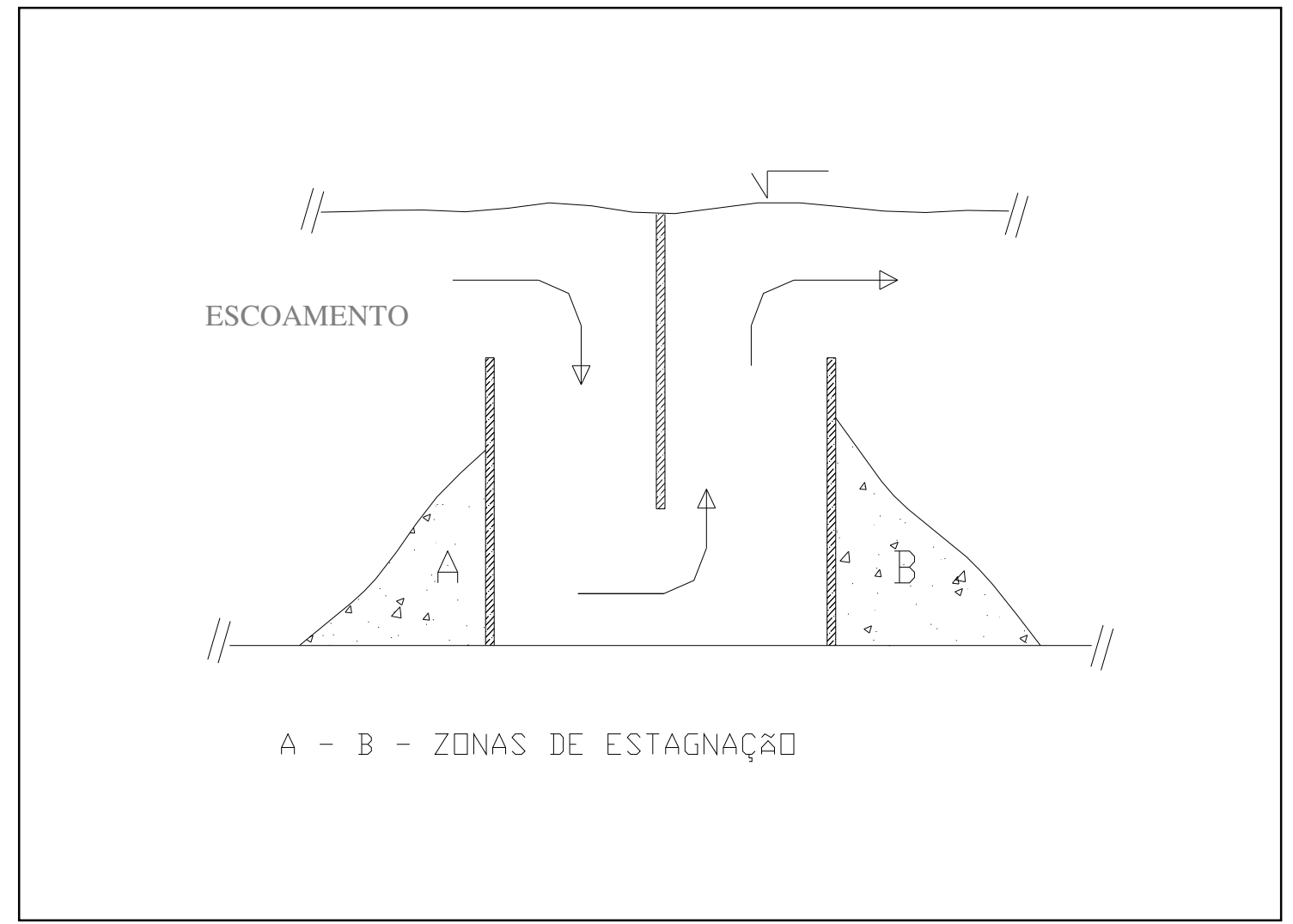

FIGURA 5.22 - Croqui do chicaneamento transversal demonstrando prováveis zonas de estagnação junto às barreiras.

- Análise quantitativa do escoamento

A FIGURA 5.23 caracteriza quantitativamente o escoamento de $11 \%$ em regime pistonado e $25 \%$ em mistura completa.

O corante atingiu rapidamente a saída, sendo que aproximadamente apenas $10 \%$ do mesmo ainda se encontrava no interior da lagoa depois de decorrido o tempo de ensaio igual a $70 \%$ do tempo de detenção hidráulico teórico, demonstrando que havia fluxo preferencial.

O gráfico possui cauda extensa diagnosticando regiões de estagnação no interior da lagoa. 


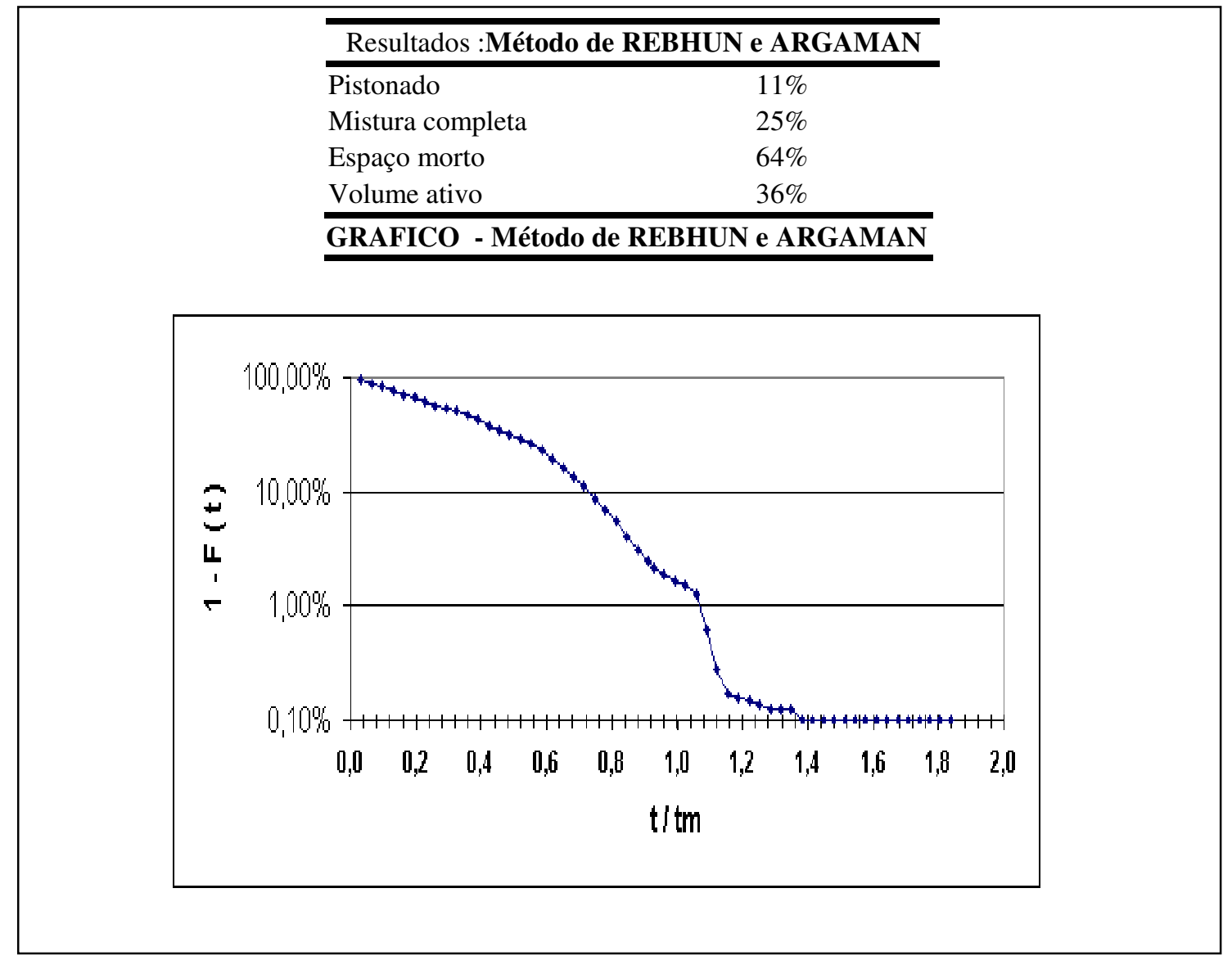

FIGURA 5.23 - Análise quantitativa do escoamento para lagoa com chicaneamento longitudinal e transversal

- Perfil de temperatura e oxigênio dissolvido

A temperatura ambiente ao longo do ensaio era elevada, impondo também elevada estratificação térmica na lagoa, sendo que a temperatura média da superfície da lagoa ficou em torno de $33^{\circ} \mathrm{C}$.

Na FIGURA 5.24 e APÊNDICE O verifica-se que a termoclina se localizou entre as profundidades de $30 \mathrm{~cm}$ e $40 \mathrm{~cm}$, sendo a temperatura abaixo da profundidade de 30 $\mathrm{cm}$ era mais homogênea e inferior $30^{\circ} \mathrm{C}$.

A FIGURA 5.25 mostra presença de elevada concentração de oxigênio na camada superior sendo que a zona aeróbia ficou comprimida entre a superfície e a profundidade de $60 \mathrm{~cm}$ durante período de estratificação térmica. Ocorreu baixa concentração de 
oxigênio abaixo de $30 \mathrm{~cm}$ de profundidade e abaixo de $60 \mathrm{~cm}$ a concentração de OD era inferior a $1 \mathrm{mg} \mathrm{O}_{2} / 1$ (ver APÊNDICE P).

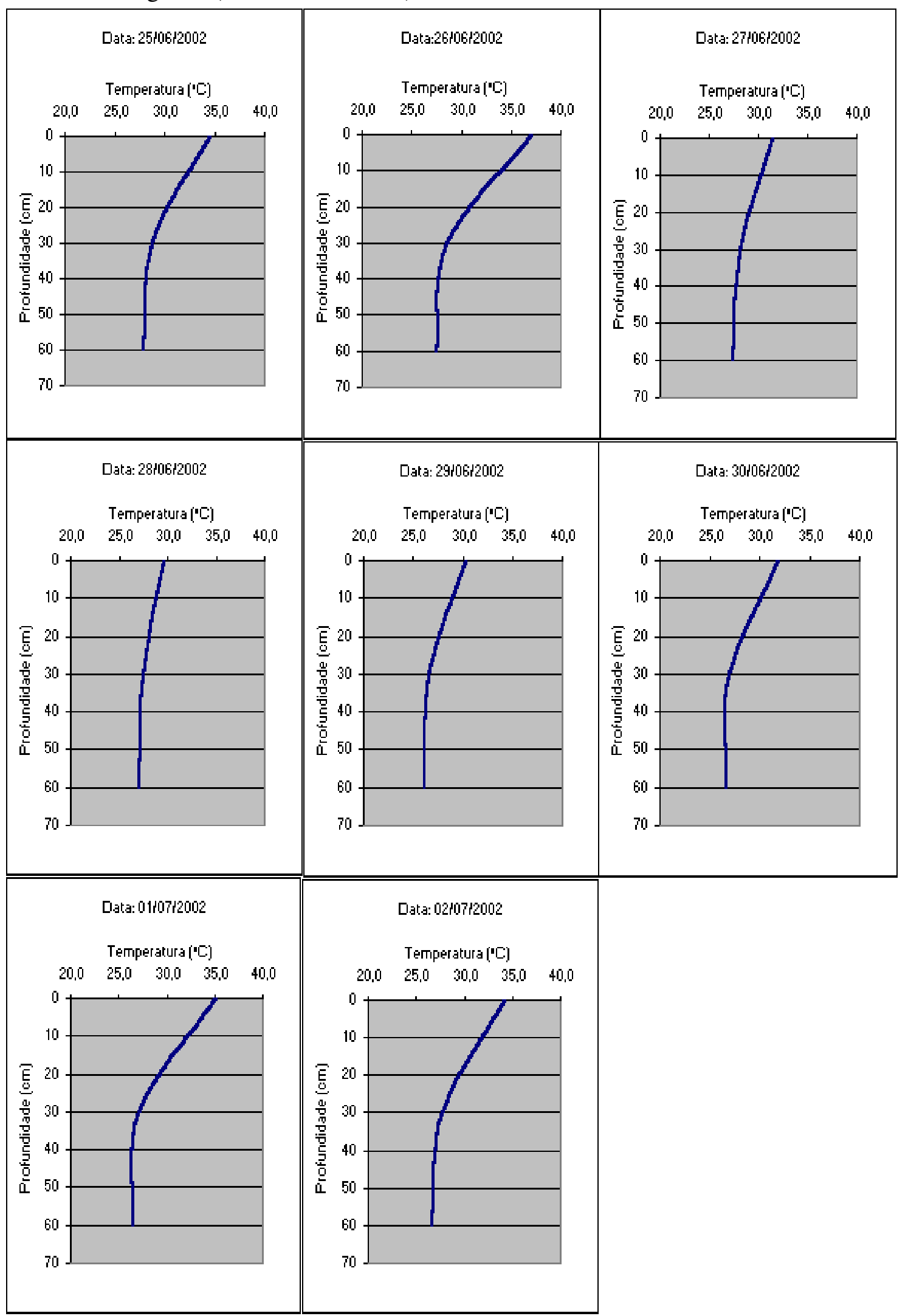

FIGURA 5.24 - Perfis de temperatura obtidos na lagoa com chicaneamento longitudinal e transversal ao longo do período de análise hidrodinâmica. Medidas às 16 horas . de cada dia . Valores médios dos pontos 1,2 e 3 conforme FIGURA 5.19. 


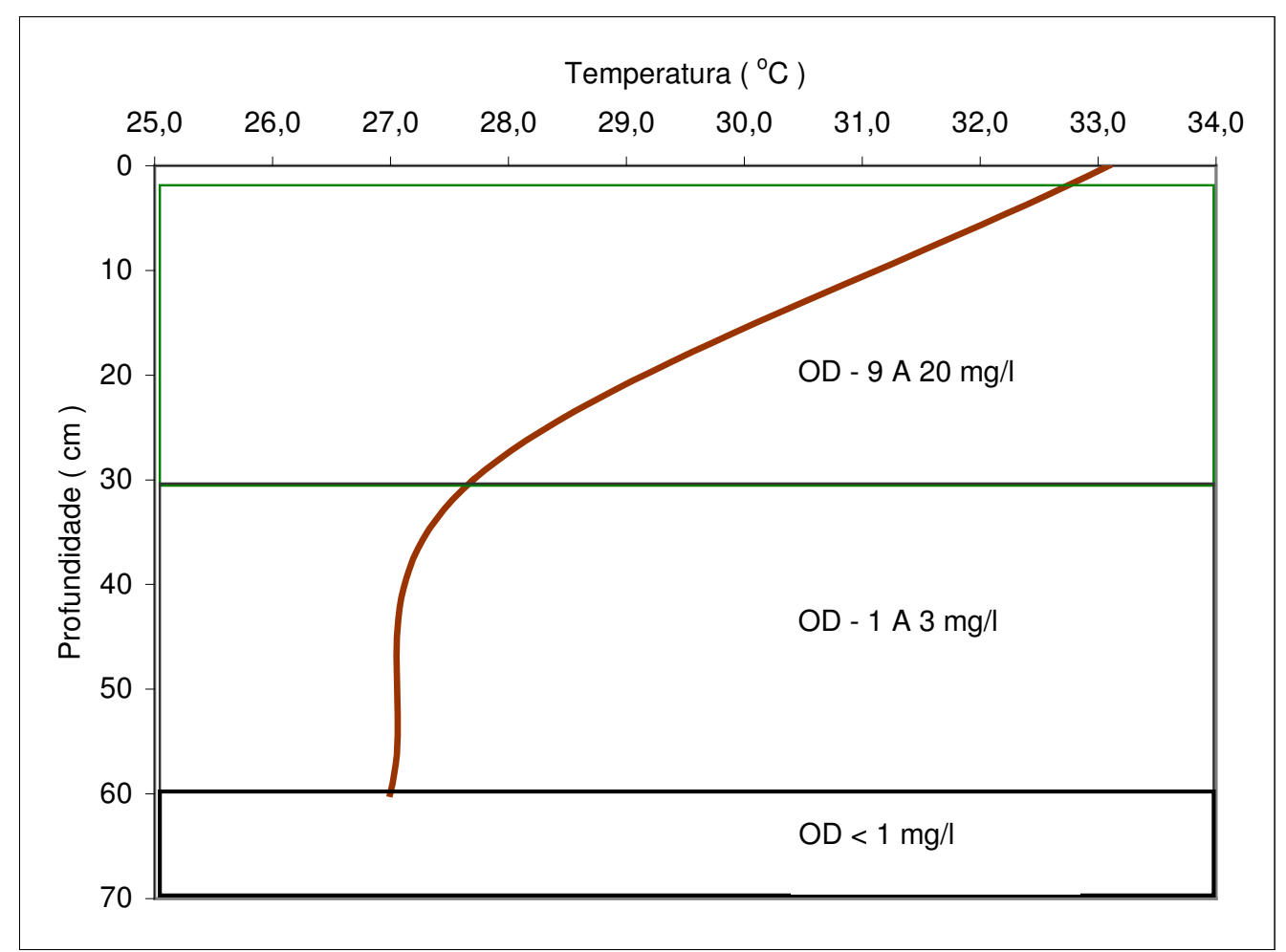

FIGURA 5.25 - Perfis de temperatura e concentração de oxigênio dissolvido obtidos na lagoa com chicaneamento longitudinal e transversal ao longo do período de análise hidrodinâmica. Medidas às 16 horas . de cada dia. Valores médios entre os dias 6/03/2002 e 14/03/2002 nos pontos 1,2 e 3 conforme FIGURA 5.19.

- Movimento e renovação do fluido na lagoa

A posição dos dispositivos de entrada e saída, ambos situados a $30 \mathrm{~cm}$ de profundidade, fizeram com que o movimento e a renovação do fluido fossem predominantes na camada intermediária entre $30 \mathrm{~cm}$ e $60 \mathrm{~cm}$ de profundidade.

Confirma-se esse fato pela FIGURA 5.26 e APÊNDICES Q e R que demonstram as concentrações de corante e DQO na coluna d'água. A menor concentração de corante indica que a região estava sofrendo diluição provocada pela vazão afluente e, a maior concentração de DQO, mostra que não haviam condições suficientes para degradação da matéria orgânica devido à passagem mais rápida do esgoto por essa camada. 


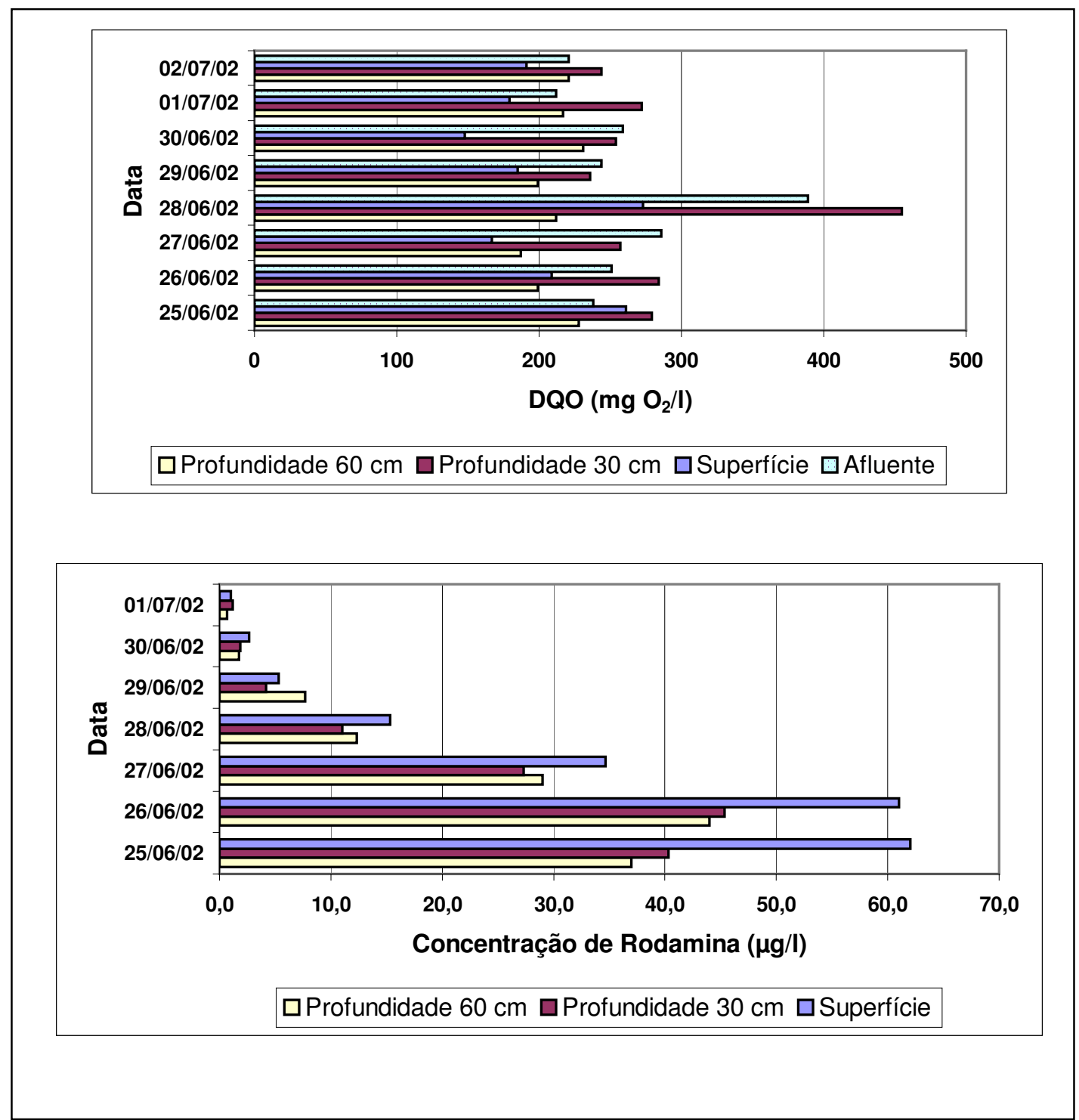

FIGURA 5.26 - Variação da concentração de DQO e corante obtido na lagoa com chicaneamento longitudinal e transversal ao longo do período de análise hidrodinâmica. Medidas às 16 horas . de cada dia. Corante: valores médios entre os dias 06/03/2002 e 13/03/2002 nos pontos 1,2 e 3. Os valores de DQO foram obtidos de amostras da retiradas no ponto 2 .

- Comparação dos experimentos

A TABELA 5.5 e as FIGURAS 5.27, 5.28, 5.29, 5.30 apresentam os resultados da comparação entre os experimentos considerando a lagoa sem chicana, com chicana longitudinal e com chicana longitudinal e transversal.

O chicaneamento longitudinal apresentou melhor desempenho em relação à eficiência hidráulica, alcançando 55\% de volume ativo, Número de Dispersão (d) de 
0,24 e $19 \%$ do regime em escoamento pistonado e $33 \%$ em mistura completa. COSSIO (1993) encontrou semelhante resposta, quando após estudos para verificação de eficiência de lagoas, visando a desinfecção de efluentes, constatou que chicanas transversais causam maior recirculação e aumento de espaço morto quando comparada com chicanas longitudinais, sendo que essa última apresenta melhor desempenho hidrodinâmico.

Considerando-se a equação (4), para igual tempo de detenção hidráulico teórico e constante de remoção $\mathrm{K}=0,4 \mathrm{dia}^{-1}$ (adotado) os resultados de eficiência de remoção para um determinado substrato seriam: lagoa sem chicaneamento 90,8 \%, lagoa com chicaneamento longitudinal $97,2 \%$ e lagoa com chicaneamento longitudinal e transversal 89,9\%, diferença associada ao Número de Dispersão (d).

Todos os experimentos apresentaram pico de concentração em tempo menor que $10 \%$ do tempo de detenção hidráulico teórico mostrando que independente da condição da instalação existia algum tipo de curto-circuito, conforme mostra a FIGURA 5.27. O pico era mais pronunciado na lagoa sem chicanas e na lagoa com chicaneamento longitudinal e transversal, sendo que o chicaneamento longitudinal reduziu esse efeito.

Na FIGURA 5.27 observa-se que a recirculação interna era maior na lagoa sem chicaneamento que apresentou vários picos na curva ao longo de todo ensaio.

Nenhuma das configurações proporcionou tempo de detenção hidráulico real próximo ao valor de tempo de detenção hidráulico teórico, sendo mais eficiente o sistema com chicaneamento longitudinal com tempo de detenção hidráulico real correspondente a 55\% do tempo de detenção hidráulico teórico e o menos eficiente a lagoa sem chicanas com 34\% de relação TDR/TDH, fato que pode ser atribuído a regiões de estagnação (zona mortas) no interior das lagoas.

A fração de corante que permaneceu no interior da lagoa era maior, para qualquer instante observado, quando se utilizou o chicaneamento longitudinal .

Para o intervalo de tempo igual a tempo de detenção hidráulico teórico ainda se encontrava presente na lagoa a fração de corante de $10 \%$ para o caso de chicaneamento longitudinal, $0,8 \%$ para o sistema sem chicana e $2 \%$ para a lagoa com chicana longitudinal e transversal, o que implicou, para lagoa com chicaneamento longitudinal, 
maior tempo de contato do substrato afluente com os microrganismos existentes no sistema e portanto melhores condições de eficiência .

TABELA 5.6 - Comparação entre as diversas fases experimentais

\begin{tabular}{|c|c|c|c|}
\hline \multirow{2}{*}{$\begin{array}{l}\text { Características } \\
\text { hidrodinâmicas }\end{array}$} & \multicolumn{3}{|c|}{ Tipo de Chicaneamento } \\
\hline & $\begin{array}{c}\text { Sem } \\
\text { chicaneamento }\end{array}$ & Longitudinal & $\begin{array}{c}\text { Longitudinal e } \\
\text { Transversal }\end{array}$ \\
\hline$\%$ Volume ativo & 34 & 55 & 38 \\
\hline$\%$ Volume morto & 66 & 45 & 62 \\
\hline $\begin{array}{l}\text { Tempo de detenção hidráulico real } \\
\text { (dias) }\end{array}$ & 2,4 & 2,8 & 1,9 \\
\hline $\begin{array}{c}\text { Tempo de detenção hidráulico } \\
\text { teórico (dias) }\end{array}$ & 7 & 5,1 & 5,1 \\
\hline$\%$ pistonado & 11 & 19 & 11 \\
\hline$\%$ mistura completa & 23 & 33 & 25 \\
\hline Número de Dispersão (d) & 0,39 & 0,24 & 0,36 \\
\hline $\begin{array}{c}\% \text { de corante que permanece na } \\
\text { lagoa para } t / t m=1\end{array}$ & 0,8 & 10 & 2 \\
\hline $\begin{array}{c}\text { Eficiência de remoção teórica- } \\
\text { equação (4) }\end{array}$ & $90,8 \%$ & $97,2 \%$ & $89,9 \%$ \\
\hline
\end{tabular}




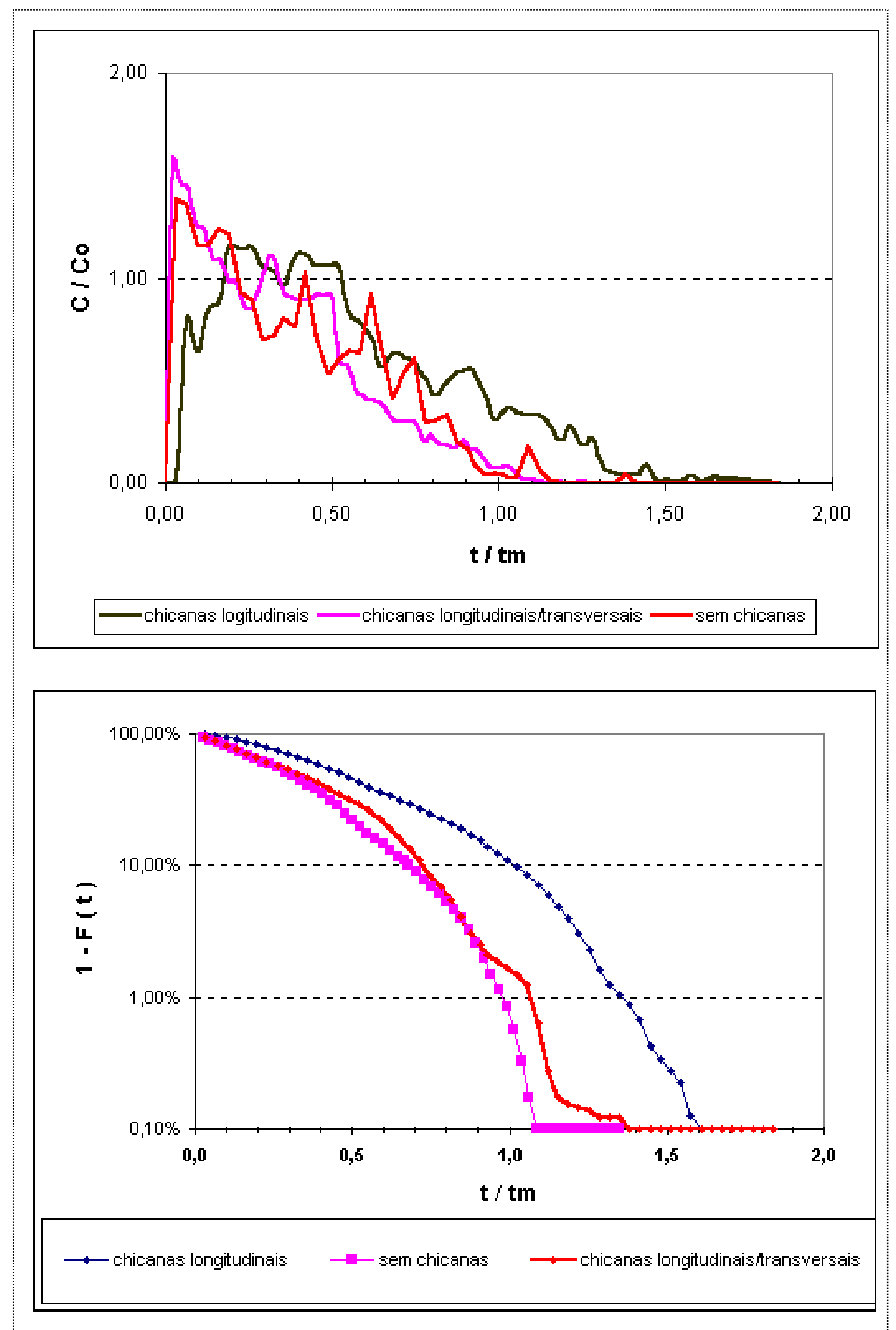

FIGURA 5.27 - Comparação entre as diversas fases experimentais - Análises quantitativas e qualitativas dos experimentos 
Lagoa sem chicanas

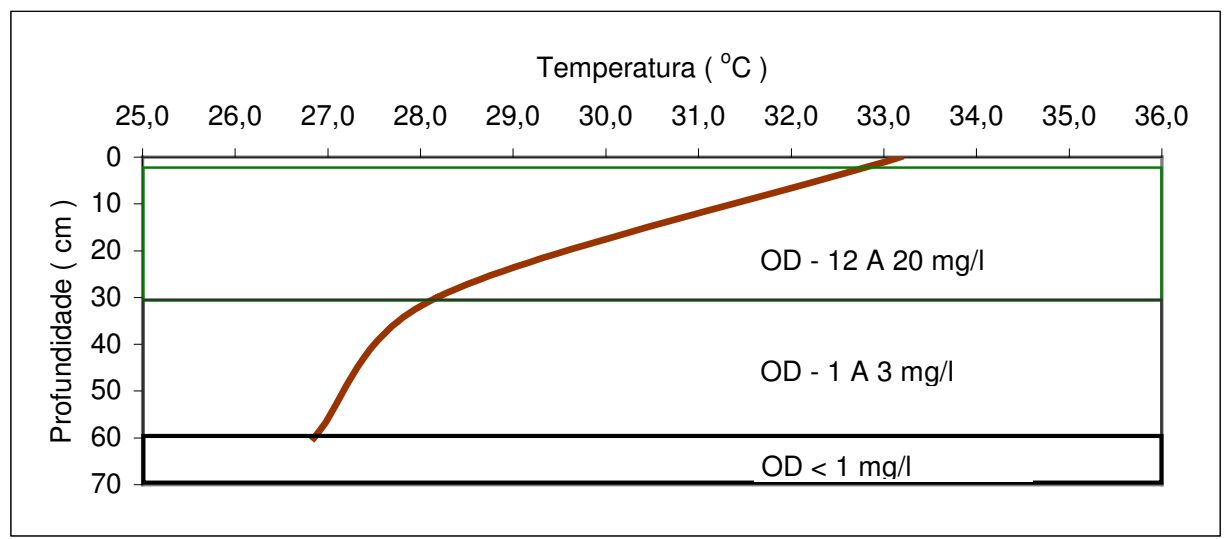

Lagoa com chicaneamento longitudinal

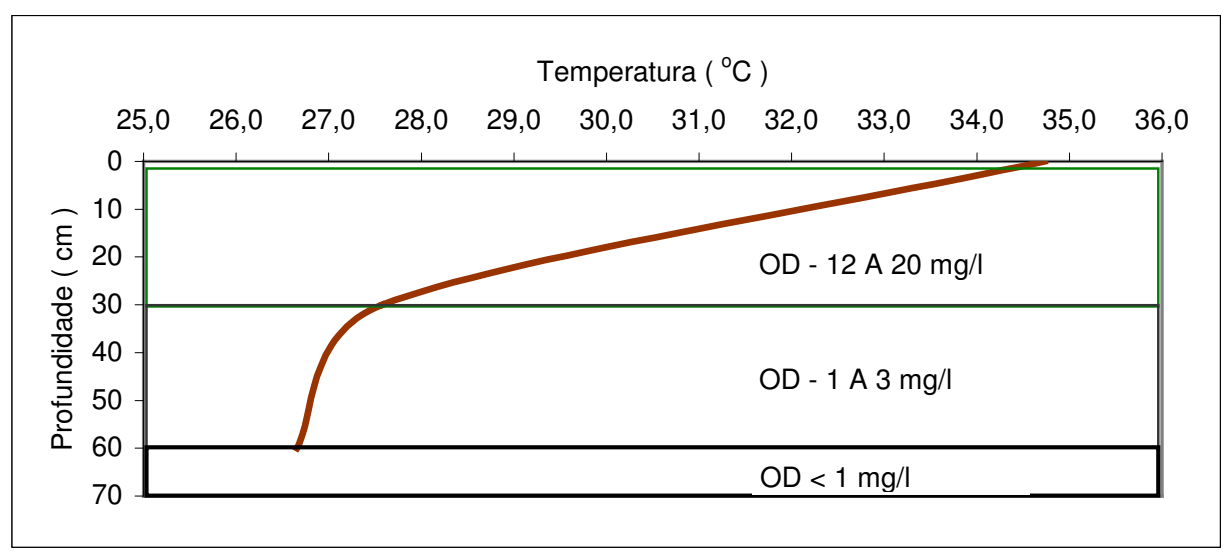

Lagoa com chicaneamento longitudinal e transversal

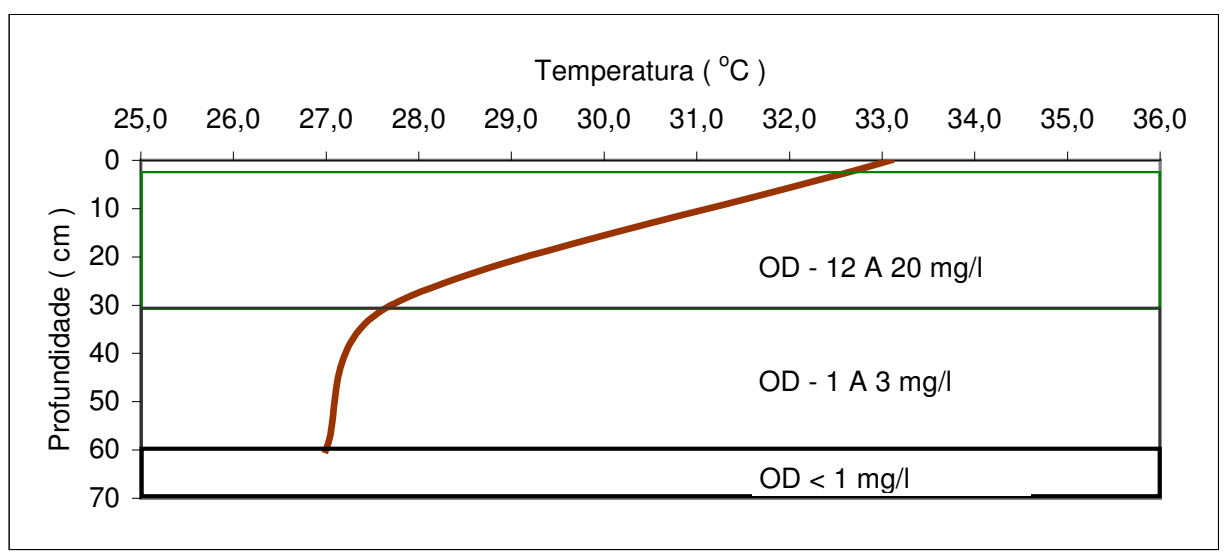

FIGURA 5.28 - Perfis de temperatura e concentração de oxigênio dissolvido obtidos nas diferentes configurações de chicaneamento ao longo do período de análise hidrodinâmica. Medidas às 16 horas de cada dia. Valor médio entre o período de cada experimento. 


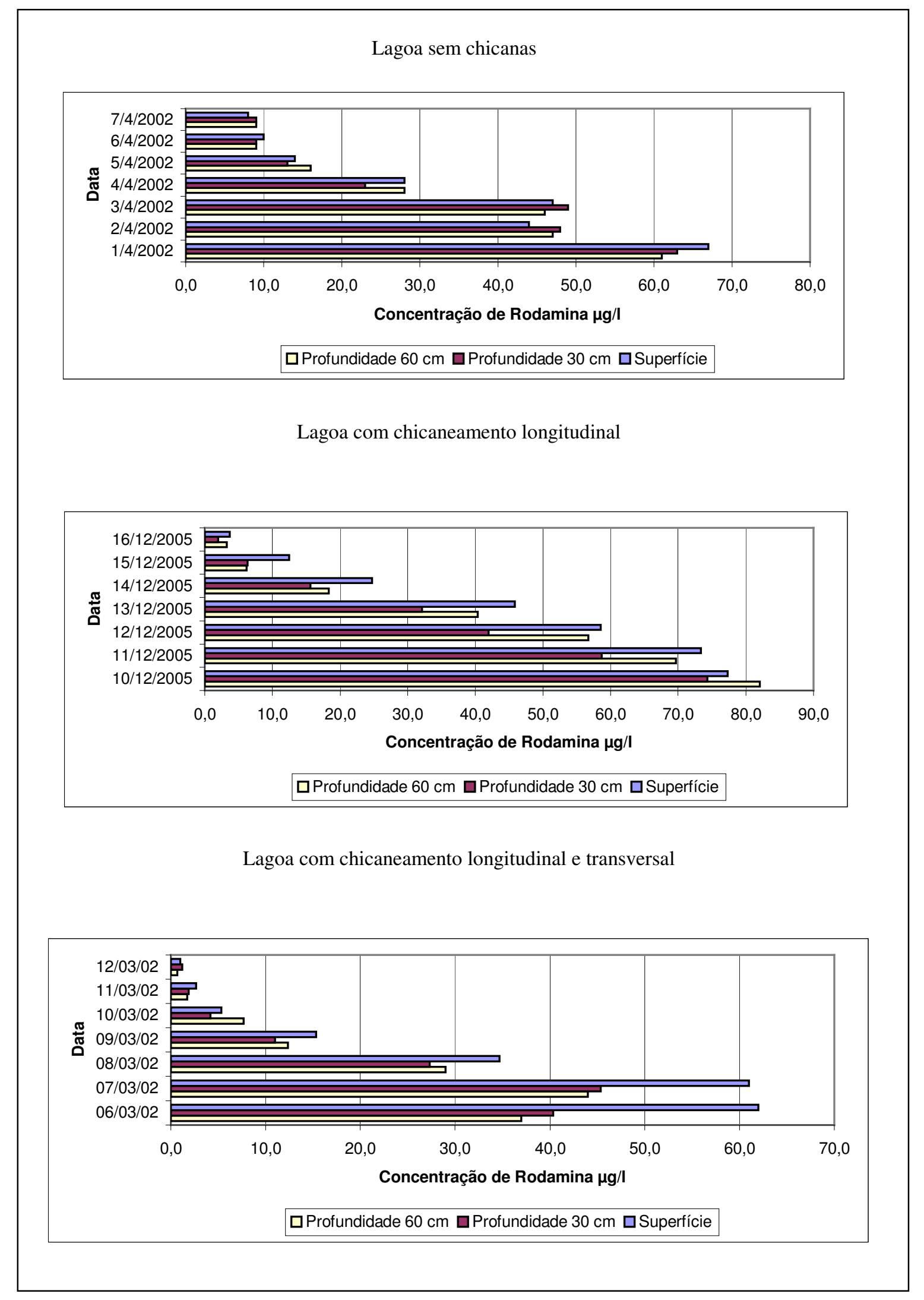

FIGURA 5.29 - Variação da concentração de corante obtida na lagoa com as diversas configurações de chicaneamento ao longo do período de análise hidrodinâmica. Medidas às 16 horas de cada dia. 


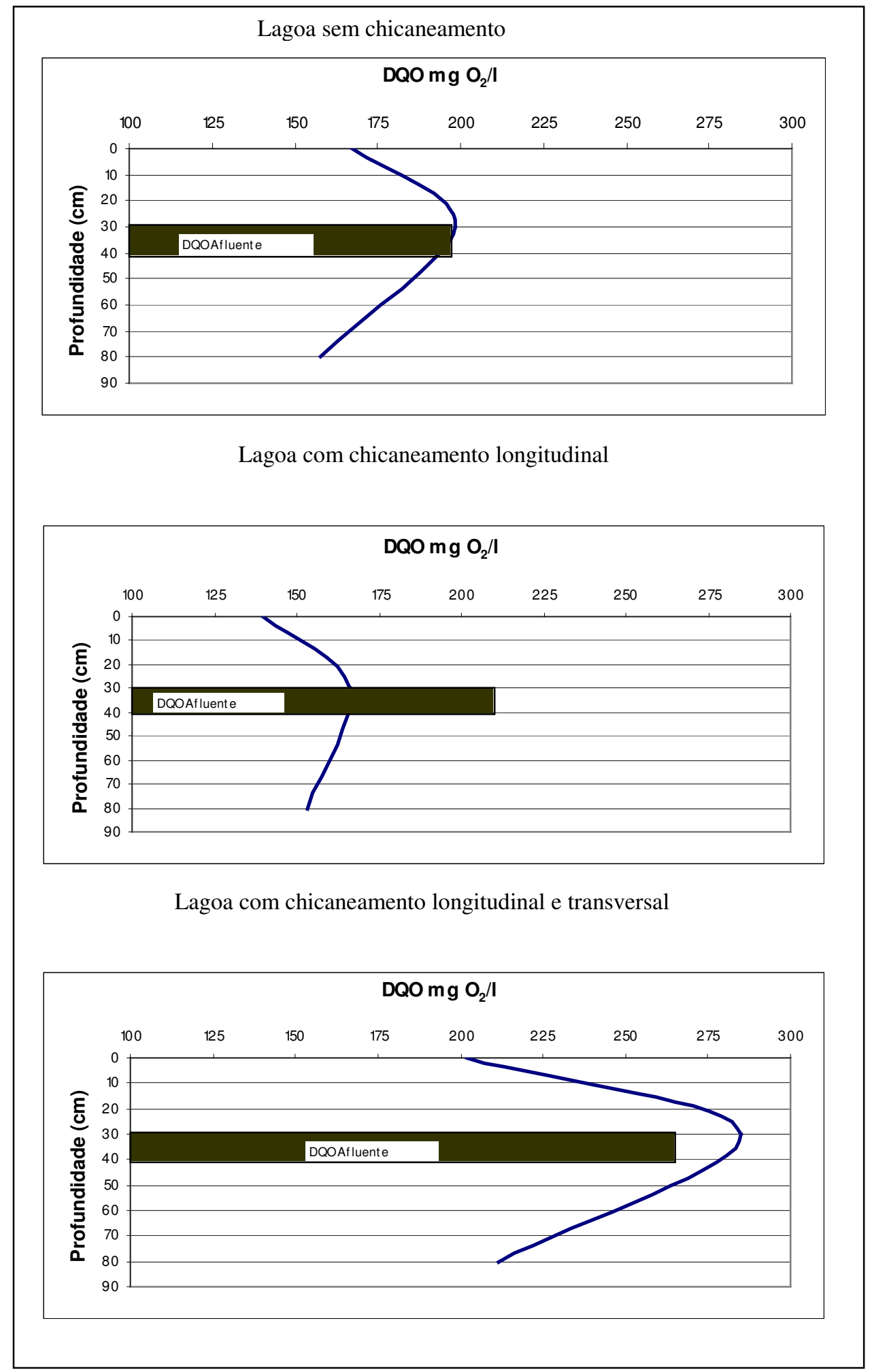

FIGURA 5.30 - Variação da concentração de DQO obtida na lagoa com as diversas configurações de chicaneamento ao longo do período de análise hidrodinâmica. Medidas às 16 horas de cada dia. 
Verificou-se o fenômeno de estratificação térmica em todos os ensaios, provocado principalmente pela elevada temperatura ambiente do local de construção da lagoa.

Verificando as FIGURAS 5.27, 5.28, 5.29 e 5.30 nota-se que alguns resultados são comuns a todos experimentos:

- Termoclina situava-se entre a profundidade de $30 \mathrm{~cm}$ e $40 \mathrm{~cm}$

- O epilímnio aeróbio era bastante diferenciado da zona hipolímnia anaeróbia. A camada superficial era altamente oxigenada com concentrações de OD superiores a de saturação enquanto a camada abaixo dos $60 \mathrm{~cm}$ teve baixa concentração de OD. A temperatura da camada superior era mais elevada chegando a superar a temperatura da inferior em $7^{\circ} \mathrm{C}$.

As condições aeróbias e de alta temperatura da camada superficial indicam que a máxima redução de matéria orgânica ocorreu nesta região. Durante o experimento verificou-se que os valores de concentração de corante e DQO ao longo do perfil da lagoa, para todos os experimentos, apresentaram características semelhantes, com menor concentração de corante e maior concentração de DQO na camada intermediária sugerindo que havia movimento e renovação do fluido nesta camada.

A concentração menor de matéria orgânica na camada inferior da lagoa indica que nesta região o fluido sofreu processo de estagnação que provocou maior tempo de detenção hidráulico e conseqüente maior grau de estabilização. Os resultados mais eficientes na camada superior estão ligados também à estagnação do fluido e à alta concentração de OD promovendo também maior grau de depuração.

Presume-se, observando os resultados, que a estagnação era maior na camada inferior, que apesar de ter baixa concentração de OD possui valores de DQO próximos aos valores de DQO da camada superficial que é mais eficiente no processo de depuração orgânica, devido à condição aeróbia.

Conclui-se que a melhor forma construtiva da lagoa piloto foi utilizando chicaneamento longitudinal que, com maior porcentagem de volume ativo, menor Número de Dispersão (d) e maior porcentagem de escoamento pistonado apresentou melhores condições hidrodinâmicas para o tratamento de esgoto sanitário. 


\section{CONCLUSÕES E RECOMENDAÇÕES}

As principais conclusões deste estudo, relacionadas com os respectivos objetivos são apresentadas a seguir:

i) Estudar o comportamento da lagoa utilizando macrófitas aquáticas: Aguapé e lentilha d'água e as vantagens e desvantagens da utilização dessas plantas no processo de depuração do esgoto sanitário.

Os resultados experimentais obtidos mostraram que a utilização das macrófitas aquáticas em lagoas de estabilização secundárias é desaconselhável, tendo em vista que apesar destas plantas terem proporcionado algumas vantagens na redução de nutrientes, nitrogênio e fósforo, existem inúmeras desvantagens ou inconvenientes que devem ser levados em conta: elevada produtividade, necessidade de manejo constante e dificuldade para disposição ou utilização da biomassa produzida.

As macrófitas aquáticas promoveram condição favorável à procriação de mosquitos tornando a área ao redor com elevado grau de infestação.

A introdução da lentilha d'água na área de estudo, espécie não nativa da região, provocou a migração dessa espécie a outros lagos próximos necessitando de trabalhos de desinfestação por meses.

O manejo freqüente das plantas provocou o desprendimento de raízes que ficavam suspensas no meio líquido aumentando teor de sólidos e matéria orgânica no efluente. 
A redução na concentração de nitrogênio total na lagoa com lentilha d'água foi de 9,9\% e na lagoa com aguapé de 29,1\% , já no caso da concentração de fósforo total, essa só era pouco significativa na lagoa com lentilha d'água, alcançando redução de $2,6 \%$.

ii) Avaliar o fenômeno de estratificação térmica de uma lagoa facultativa secundária em escala piloto tratando esgoto sanitário proveniente do sistema de coleta da cidade de Novo Horizonte, SP utilizando dois tipos de chicaneamento: longitudinal e longitudinal e transversal, e compará-los com sistema sem chicaneamento.

As características do escoamento, em todos os experimentos, eram intermediárias entre escoamento pistonado e mistura completa. Os resultados encontrados sugerem ocorrência de grande quantidade de dispersão, mas não de modelo de mistura completa perfeita.

A região aeróbia, com elevada concentração de oxigênio, alcançou a mesma profundidade da termoclina, demonstrando que a zona mais ativa ficou, durante o período de estratificação, comprimida entre a superfície e a profundidade de $30 \mathrm{~cm}$.

Independente do tipo de configuração utilizado, sem chicaneamento, com chicaneamento longitudinal ou com chicaneamento transversal ou longitudinal, ocorreu estratificação térmica no sistema.

O escoamento predominante ocorreu na região intermediária da lagoa entre $30 \mathrm{~cm}$ de profundidade e $40 \mathrm{~cm}$ de profundidade demonstrando, forte influência da posição dos dispositivos de entrada, da temperatura do esgoto afluente e da estratificação térmica sobre o deslocamento do fluído no interior da lagoa.

O sistema que mais se aproximou dos valores teóricos, com relação ao tempo de detenção hidráulico e Número de Dispersão (d), foi a lagoa com chicaneamento longitudinal, alcançando volume útil de $55 \%$ do volume total e Número de Dispersão (d) 0,24 .

O uso do chicaneamento longitudinal melhorou o comportamento hidráulico do sistema, podendo ser considerado uma medida simples e de baixo custo para incrementar a eficiência de lagoas de estabilização. 
O tempo de detenção hidráulico foi bastante afetado pela estratificação térmica, portanto em projetos de lagoas de estabilização em regiões de clima quente deve-se levar em conta esse fenômeno corrigindo o tempo de detenção hidráulico teórico para garantir os resultados de eficiência do sistema. 


\section{SUGESTÕES PARA TRABALHOS FUTUROS}

- Estudar outros tipos de macrófitas aquáticas, principalmente macrófitas aquáticas emergentes e a influência dessas na eficiência de lagoas de estabilização, levando em conta o foco operacional.

- Analisar o desempenho de um sistema de lagoas de estabilização em série tendo como última fase, lagoa afótica para retenção de algas

- Aplicar em lagoa, considerando escala real, o chicaneamento longitudinal, comparando os dados obtidos com o desempenho da lagoa sem chicaneamento

- Utilizar em lagoa, considerando escala real, captação do efluente pela superfície, e comparar o desempenho com sistema convencional com captação afogada. 


\section{EFERÊNCIAS BIBLIOGRÁFICAS}

AL - NOZAILY, F.; ALAERTS, G.; VEENSTRA, S. (2000). Performance of duckweed-covered sewage lagoons. Wat. Res. Vol. 34, nº10, pp 2727 - 2733.

APHA (1989) - Standard Methods for the examination of water and wastewater. $17^{\mathrm{a}} \mathrm{ed}$. Washington: American Public Health Association.

ASSOCIAÇÃO BRASILEIRA DE NORMAS TÉCNICAS (1990)- NB 570. Projeto de Estações de Tratamento de Esgoto Sanitário .Rio de Janeiro.

BEZERRA FRANCISCO C.L (1997) . Reuso Planejado de Águas Residuárias em Irrigação - Dissertação de Mestrado - Ceará: Universidade Federal

BRANCO, S.M. (1996) Hidrobiologia Aplicada à Engenharia Sanitária. $3^{\mathrm{a} e d}$ - - São Paulo: CETESB/ASCETESB

CAMPOS, J. R. et al. (2000) Conceitos Gerais sobre Técnicas de Tratamento de Águas de Abastecimento, Esgotos Sanitários e Desinfecção - São Carlos - Departamento De Hidráulica E Saneamento: CESC/USP

CHAIPRATAT, SUMATE; CHENG, JIAYANG; CLASSEN, JHON. (2000). Modeling nitrogen transport pond for secondary treatment of swine wastewater. Journal of Environmental Engineering. Vol. 129. № 8.

COSSIO, F. YÁNEZ. (1993). Lagunas de Estabilización - Teoría, Diseño, Evaluación y Mantenimiento. OPS / OMS. 
DOR, I.; FURER, O.; ADIN, A.; BEN-YOSEF, N. (1993). Turbidity related to surface temperature in Oxidation Ponds: Studies Tomard Development of a Remote Sensing Method. Wat. Sci. Tech, V.27, N.7-8, pp. 37-44.

DOREGO, N.C. ; LEDUC, R. (1996). Characterization of hydraulic flow patterns in facultative aerated lagoons. Wat. Sci. Tech. Vol. 34, nº11, pp 99 - 106.

ESTEVES, F. A. (1998). Fundamentos de Limnologia. Rio de Janeiro: Interciência/ FINEP, 1988. 575 pp.

FERRARI, F.F.; NASCIMENTO, C.G. TEIXEIRA, C.E.; GONÇALVES, R.F.; (1996). Seleção de traçador para estudo hidrodinâmico de lagoas de estabilização não mecanizadas. Universidade Federal do Espírito Santo. PROSAB/FINEP.

FREITAS, Queiros J. M. (2000). Manual Prático de Compostagem Orgânica Artesanal. VFP.

GASI, TÂNIA M. T. (1983). Opções para Tratamento de Esgotos de Pequenas Comunidades. São Paulo: CETESB.

GOLTERMAN, H. L.; CLYMO, R. S.; OHNSTAD, M. A. M. (1978). Methods for Chemical Analysis of Freshwater. IBP Handbook, n. 8, Oxford: Blackwell Scientific Publications. 213 pp.

GOMIDE, J. A. et al. (1974). Manual: Competição de gramíneas forrageiras para corte. V.3, p 191 - 209. Universidade Federal de Minas Gerais: Viçosa.

GRIEGO, J. R. (1994). Alternativas para tratamento de Esgotos - Pré-Tratamento de Águas para Abastecimento. Americana: Consorcio Intermunicipal das Bacias dos Rios Piracicaba e Capivari.

HANCOCK, S.J.C., BUDD.HAVARAPU, L - (1993). Control of algae using duckweed (Lemma) Systems - CRC Press, Inc.

HAWAI, H. et al. (1987). Pilot Scale Experiments in water Hyacinth Lagoons for Wastewater Treatment - IAWPRC, Water and Science Technology, Vol. 19, nº 10.

HORTEGAL, MARIA S.R. 1999.- Perspectiva de Uso das Lagoas de Manutenção na Piscicultura - Dissertação de Mestrado - CEARÁ - Universidade Federal.

HUDSON, H. E.; WOLFNER, J.P. (1967). Design of mixing and flocculation basins. J. AWWA, pp. 59 - 1257. 
ITOC - COMPANHIA DE SANEAMENTO BÁSICO DO ESTADO DE SÃO PAULO (2000) Relatórios de análises Físico Químicas. Lins.

JIRKA, G.H.; ASCE, AM. WATANABE,M. (1980) Thermal Structure of Cooling Ponds. Journal of the Hydraulics Division - HYS - MAY. p. 701 - 715.

JORDÃO, E.P., PESSOA C. (1995)- Tratamento de Esgotos Domésticos -3 ${ }^{\mathrm{a}}$ ed. - Rio de Janeiro: ABES.

KAMIYAMA, HISSASH. (1990). Teorias Modernas sobre Lagoas de Estabilização Seminário Interno. SABESP.

KELLNER, E. (1996). Lagoas de estabilização empregadas no tratamento de esgotos sanitários: Revisão analítica - descritiva. 371 p. Dissertação de Mestrado. São Carlos: EESC/USP.

KELLNER, E. (2000). Modelação matemática do comportamento térmico de lagoas de estabilização: A estratificação e seus efeitos. Tese de Doutorado. São Carlos: EESC/USP.

KELLNER, E., PIRES, E. C. (1998) - Lagoas de Estabilização: Projeto e Operação. Rio de Janeiro: ABES, 241p.

KELLNER, E.; PIRES, E.C. (1999). Desenvolvimento de modelo matemático para determinação do perfil vertical de temperatura e do volume útil de lagoas de estabilização. Revista de Engenharia Sanitária e Ambiental. Vol. 4, nº1, pp 84 - 92.

KILANI, J.S. ; OGUNROMBI, J. A. (1984). Effects of baffles on the performance of model waste stabilization ponds. Water Res. № 18, 941-944.

KIM, Y. KIM, W.J. (2000). Roles of water hyacinths and their roots for reducing algae concentration in the effluent from waste stabilization ponds. Wat. Res. Vol. 34, nº13, pp. $3285-3294$.

LAREO, L. \& BRESSANI, R. (1982). Possible utilization of the water hyacinth in nitration and industry. Division of agriculture and food science. Institute of nutrition of Central America and Panama, Guatemala City, Guatemala (Food and Nutrition Bulletin), 4(4): 60-4.

LEME, FRANCILIO PAES. (1990). Teoria e Técnicas de tratamento de Água $-2^{\mathrm{a}}$ edição - Rio de Janeiro: ABES. 
LEVENSPIEL, O. (1974). Engenharia das Reações Químicas. V. 2. Cálculo de Lagoaes. São Paulo. Editora Edgard Blucher Ltda.

LINSLEY, RK, FRANZINI, J.B. (1978). Engenharia de Recursos Hídricos-1 ${ }^{\mathrm{a}}$ ed. MCGRAW- HILL. São Paulo.

LLORENS, M; SAÉZ, J.; SOLER, A. (1992). Influence of thermal stratification on the behavior of a deep stabilization pond. Wat. Res., Vol. 26, nº5, p. 569 - 577.

LUTZENBERGER, JOSÉ. (1985). Ecologia - Do Jardim do Poder - Porto Alegre, L\&PM Editores Ltda.

MANCUSO (1998) Reuso da Água - Dissertação de Mestrado, Faculdade de Saúde Pública da USP .São Paulo:USP

MARECOS DO MONTE, M.H.F.; MARA, D.D. (1987). The hydraulic performance of waste stabilization ponds in Portugal. Wat. Sci. Tech. Vol. 19, nº12, pp. 219 - 227.

METCALF \& EDDY. INC. (1991). Wastewater Engineer -Treatment, disposal and reuse. New York, Ed. McGraw Hill.

MITSUDA, H. (1978). Protein Concentrated from Water Hyacinth and its amino acid composition - J. Japanese Soc. Fd. Nvtr, 31 (1): 99-102.

MORENO, M.D. (1990). A tracer study of the hydraulics of facultative stabilization ponds. Wat. Res. Vol. 24, nº, pp. 1025 - 1030.

MOTA, SUETÔNIO (1980). Aplicação de Esgoto doméstico em Irrigação - Tese de Seleção para Professor Titular - Ceará: Universidade Federal.

NAMÉCHE, T.; VASSEL, J.L. (1996) New method for studying the hydraulic behavior of tanks in series: Application to aerated lagoons and waste stabilization ponds. Wat. Sci. Tech. Vol. 33, nº, pp $105-124$.

NEVES, CARLOS A.C. (1999). Aspectos Sanitários do Reuso de Água na Agricultura - Dissertação de Mestrado. Ceará: Universidade Federal:.

NOGUEIRA, VERA L. M. (1999). Caracterização do Sistema de Lagoas de Estabilização da Estação de Tratamento de Esgotos do Parque Fluminense. Fortaleza, Ceará. Dissertação de Mestrado. Ceará: Universidade Federal. 
ORON, G.; STEEN, P.; BRENNER, A. (1998). An integrated duckweed and algae pond system for nitrogen removal and renovation. Wat. Sci. Tech. Vol. 38, nº 1 , pp 335 $-343$.

PAGANINI, W. (1982). Disposição de Esgotos no Solo. Dissertação de mestrado. Faculdade de Saúde Pública. São Paulo: USP

PIVELLI, R.P.; PEREIRA, M.C.D. (2003). Condições operacionais de sistemas de tratamento de esgotos por lagoas de estabilização em LINS / SP - $22^{\circ}$ Congresso Brasileiro de Engenharia Sanitária e Ambiental Joinville, Santa Catarina.

PIVELLI, ROQUE PASSOS (1996). Qualidades das Águas. Faculdade de Saúde Pública. São Paulo/USP.

RECH, ANTÔNIO LINUS (1992). Água: Micromedição e Perdas: DMAE, Porto Alegre

ROCHA, A.A. (1975). Ensaios com vegetação Aquática - Aspectos Sanitários e Ecológicos - Aspectos Sanitários e Ecológicos - Revista DAE 103.

SABESP (2001). Relatório Operacional do Sistema de Tratamento de Esgoto de Novo Horizonte / SP. Unidade RT DO2.

SABESP (2002). Relatórios Operacionais de Lagoas de Estabilização. Unidade IT. Lins.

SABESP (2003). Companhia de Saneamento Básico do Estado de São Paulo Relatório de Acompanhamento de Estações de Tratamento de Esgoto - TRATESG Unidade RO.

SILVA, S. A., MARA, D. O. (1979). Lagoas de Estabilização - $1^{\text {a }}$ ed. Rio de Janeiro: ABES.

SILVIA, A.S. (1982). Tratamento de Esgotos domésticos em Lagoas de Estabilização no nordeste do Brasil. Tese (Doutorado). Tradução. Departamento de Engenharia Civil. 249 p. Escócia: Universidade de Dundee.

SIMI, A. L.; MITCHELL, C. A. (1999). Design and hydraulic performance of a constructed wetland treating oil refinery wastewater. Wat. Sci. Tech. Vol. 40, n⿳3, pp $301-307$. 
STRANO, C.V. (1986). Produção e caracterização de concentração Protéica do Aguapé - Piracicaba . Dissertação de mestrado. ESALQ./USP.

TENNESSEN, K.J. (1993). Production and suppression of mosquitoes in constructed wetlands. CRC Press, Inc. - Chapter 66.

THOMAS, P.R. (1981). Aeration and Water Hyacinths in Waste Stabilization - Ponds Water Science Technology vol. 19 - N12.

TORRES, J.J.; SOLER, A. J.; ORTUNO, J.F. (1997). Hydraulic Performance of a deep wastewater stabilization pound. Wat. Res., Vol. 31, nº4, pp 679 - 688.

UEHARA, M.Y., VIDAL W.L. (1989). Operação e Manutenção de lagoas anaeróbias e facultativas. São Paulo: CETESB.

VAN DER STEEN, P.; BRENNER, A.; BUUREN, V.; ORON, G. (1999). Post Treatment of UASB reactor effluent in an integrated duckweed and stabilization pond system. Water Res. Vol. 33, n³, pp. 615 - 620.

VANZO, José Everaldo (1990). Importância da mistura em lagoas de Estabilização Apostila do curso sobre técnicas de tratamento de Esgoto - SABESP - Franca .

VICTORETTI, B. A. (1993). Contribuição ao emprego de lagoas de estabilização como processo para depuração de esgotos domésticos. São Paulo: CETESB.

VIDAL, W.L. (1983) Aperfeiçoamento hidráulico no projeto de Lagoas de Estabilização visando redução na área de tratamento: uma aplicação prática, In: $12^{\circ}$ CONGRESSO BRASILEIRO DE ENGENHARIA SANITÁRIA E AMBIENTAL. Anais Balneário de Camboriu. CETESB, São Paulo, 38p.

VON SPERLING, M.V. (1996). Princípios de Tratamento de Águas Residuárias. Volume 3: Lagoas de Estabilização -Belo Horizonte, DESA/UFMG.

WEHNER, J.F. e WILHELN, R.H (1956). Boundary conditions of flow reactor. Chemical Engineering Science. 6 (1): 89 - 93.

WOLF, D.; RESNICK, W. (1963). Residence time distribution in real systems. I EC Fundamentals, Vol. 2, nº 4 , pp 287 - 293.

WOLVERTON, B.C.; McDONALD, R.C.(1978). Nutrition composition of water hyacinth grow on domestic sewage. Economic Botany, 32(4): 363-70. 
YAN, JINGSONG - CASE STUDY (1989) The conversion of Wastewater into Utilizable Resources Using Water Hyacinths. China: Funmentang University 
APÊNDICE A - Resultados de análises físico-químicas e bacteriológicas do esgoto afluente à lagoa com aguapé (valores de 7 amostras compostas, 6 alíquotas por amostra, coletadas 1 vez por semana por 7 semanas consecutivas). 


\begin{tabular}{|c|c|c|c|c|}
\hline \multirow{2}{*}{ Parâmetro } & \multirow{2}{*}{ Un. } & \multicolumn{3}{|c|}{ Concentrações } \\
\hline & & Média & Máxima & Mínima \\
\hline Oxigênio Dissolvido & $(\mathrm{mg} / \mathrm{l})$ & 7,8 & 8,3 & 7,4 \\
\hline Sólidos Totais & $(\mathrm{mg} / \mathrm{l})$ & 523 & 653 & 428 \\
\hline Sólidos Totais Fixos & $(\mathrm{mg} / \mathrm{l})$ & 271 & 344 & 225 \\
\hline Sólidos Totais Voláteis & $(\mathrm{mg} / \mathrm{l})$ & 252 & 309 & 203 \\
\hline $\begin{array}{c}\text { Sólidos Suspensos } \\
\text { Totais }\end{array}$ & $(\mathrm{mg} / \mathrm{l})$ & 97 & 180 & 80 \\
\hline $\begin{array}{c}\text { Sólidos Suspensos } \\
\text { Fixos }\end{array}$ & $(\mathrm{mg} / \mathrm{l})$ & 8 & 60 & 13 \\
\hline $\begin{array}{c}\text { Sólidos Suspensos } \\
\text { Voláteis }\end{array}$ & $(\mathrm{mg} / \mathrm{l})$ & 89 & 120 & 67 \\
\hline DQO & $(\mathrm{mg} / \mathrm{l})$ & 200 & 267 & 142 \\
\hline $\mathrm{DBO}_{5}$ & $(\mathrm{mg} / \mathrm{l})$ & 80 & 105 & 66 \\
\hline Fósforo Total & $(\mathrm{mg} / \mathrm{l})$ & 4,3 & 4,5 & 4,2 \\
\hline Condutividade & $(\mu \mathrm{s} / \mathrm{cm})$ & 845 & 870 & 823 \\
\hline Coliformes Totais & NMP & $7.95 \times 10^{6}$ & $8.2 \times 10^{6}$ & $7.7 \times 10^{6}$ \\
\hline Coliformes Fecais & NMP & $3.6 \times 10^{5}$ & $3.7 \times 10^{5}$ & $3.4 \times 10^{5}$ \\
\hline $\begin{array}{c}\text { Nitrogênio Total } \\
\text { Kjedhal }\end{array}$ & $(\mathrm{mg} / \mathrm{l})$ & 37 & 42 & 24 \\
\hline Nitrogênio Amoniacal & $(\mathrm{mg} / \mathrm{l})$ & 31 & 40 & 17 \\
\hline
\end{tabular}


APÊNDICE B - Resultados de análises físico-químicas e bacteriológicas do esgoto efluente da lagoa de maturação durante o período de ensaio da lagoa piloto com aguapé (valores de 7 amostras compostas, 6 alíquotas por amostra, coletadas 1 vez por semana por 7 semanas consecutivas). 


\begin{tabular}{|c|c|c|c|c|}
\hline \multirow{2}{*}{ Parâmetro } & \multicolumn{4}{|c|}{ Concentração } \\
\hline & Un. & Média & Máxima & Mínima \\
\hline Oxigênio Dissolvido & $(\mathrm{mg} / \mathrm{l})$ & 6,9 & 8,1 & 5,5 \\
\hline Sólidos Totais & $(\mathrm{mg} / \mathrm{l})$ & 486 & 543 & 480 \\
\hline Sólidos Totais Fixos & $(\mathrm{mg} / \mathrm{l})$ & 267 & 300 & 237 \\
\hline Sólidos Totais Voláteis & $(\mathrm{mg} / \mathrm{l})$ & 219 & 243 & 243 \\
\hline $\begin{array}{c}\text { Sólidos Suspensos } \\
\text { Totais }\end{array}$ & $(\mathrm{mg} / \mathrm{l})$ & 57 & 79 & 49 \\
\hline $\begin{array}{c}\text { Sólidos Suspensos } \\
\text { Fixos }\end{array}$ & $(\mathrm{mg} / \mathrm{l})$ & 2 & 2 & 2 \\
\hline $\begin{array}{c}\text { Sólidos Suspensos } \\
\text { Voláteis }\end{array}$ & $(\mathrm{mg} / \mathrm{l})$ & 55 & 77 & 47 \\
\hline DQO & $(\mathrm{mg} / \mathrm{l})$ & 190 & 233 & 131 \\
\hline $\mathrm{DBO}_{5}$ & $(\mathrm{mg} / \mathrm{l})$ & 85 & 90 & 41 \\
\hline Fósforo Total & $(\mathrm{mg} / \mathrm{l})$ & 6,5 & 6,8 & 6,4 \\
\hline Condutividade & $(\mu \mathrm{s} / \mathrm{cm})$ & 830 & 839 & 822 \\
\hline Coliformes Totais & NMP & $2 \times 10^{6}$ & $3.8 \times 10^{6}$ & $2 \times 10^{6}$ \\
\hline Coliformes Fecais & NMP & $3.5 \times 10^{4}$ & $4 \times 10^{4}$ & $3 \times 10^{4}$ \\
\hline $\begin{array}{c}\text { Nitrogênio Total } \\
\text { Kjedhal }\end{array}$ & $(\mathrm{mg} / \mathrm{l})$ & 31 & 42 & 21 \\
\hline Nitrogênio Amoniacal & $(\mathrm{mg} / \mathrm{l})$ & 27 & 30 & 16 \\
\hline Nitrato $\left(\mathrm{NO}_{3}\right)$ & $(\mathrm{mg} / \mathrm{l})$ & 0,1 & 0,1 & 0,1 \\
\hline
\end{tabular}


APÊNDICEC-Resultados de análises físico-químicas e bacteriológicas do esgoto efluente da lagoa com aguapé (valores de 7 amostras compostas, 6 alíquotas por amostra, coletadas 1 vez por semana por 7 semanas consecutivas). 


\begin{tabular}{|c|c|c|c|c|}
\hline \multirow{2}{*}{ Parâmetro } & \multicolumn{4}{|c|}{ Concentração } \\
\hline & Un. & Média & Máxima & Mínima \\
\hline Oxigênio Dissolvido & $(\mathrm{mg} / \mathrm{l})$ & 1,2 & 1,4 & 1,1 \\
\hline Sólidos Totais & $(\mathrm{mg} / \mathrm{l})$ & 509 & 665 & 538 \\
\hline Sólidos Totais Fixos & $(\mathrm{mg} / \mathrm{l})$ & 271 & 476 & 245 \\
\hline Sólidos Totais Voláteis & $(\mathrm{mg} / \mathrm{l})$ & 238 & 189 & 293 \\
\hline $\begin{array}{c}\text { Sólidos Suspensos } \\
\text { Totais }\end{array}$ & $(\mathrm{mg} / \mathrm{l})$ & 80 & 123 & 25 \\
\hline Sólidos Suspensos Fixos & $(\mathrm{mg} / \mathrm{l})$ & 6 & 13 & 1 \\
\hline $\begin{array}{c}\text { Sólidos Suspensos } \\
\text { Voláteis }\end{array}$ & $(\mathrm{mg} / \mathrm{l})$ & 74 & 110 & 24 \\
\hline DQO & $(\mathrm{mg} / \mathrm{l})$ & 140 & 151 & 123 \\
\hline $\mathrm{DBO}_{5}$ & $(\mathrm{mg} / \mathrm{l})$ & 68 & 88 & 40 \\
\hline Fósforo Total & $(\mathrm{mg} / \mathrm{l})$ & 6,4 & 7,1 & 5,8 \\
\hline Condutividade & $(\mu \mathrm{s} / \mathrm{cm})$ & 847 & 856 & 839 \\
\hline Coliformes Totais & NMP & $2.1 \times 10^{6}$ & $3.4 \times 10^{6}$ & $7.9 \times 10^{6}$ \\
\hline Coliformes Fecais & NMP & $1.2 \times 10^{3}$ & $1.6 \times 10^{3}$ & $7.4 \times 10^{3}$ \\
\hline $\begin{array}{c}\text { Nitrogênio Total } \\
\text { Kjedhal }\end{array}$ & $(\mathrm{mg} / \mathrm{l})$ & 26 & 36 & 18 \\
\hline Nitrogênio Amoniacal & $(\mathrm{mg} / \mathrm{l})$ & 25 & 32 & 18 \\
\hline Nitrato $\left(\mathrm{NO}_{3}\right)$ & $(\mathrm{mg} / \mathrm{l})$ & 0,5 & 0,6 & 0,4 \\
\hline Nitrito $\left(\mathrm{NO}_{2}\right)$ & $(\mathrm{mg} / \mathrm{l})$ & n.d & n.d & n.d. \\
\hline
\end{tabular}


APÊNDICE D-Resultados de análises físico-químicas e bacteriológicas do esgoto afluente à lagoa com lentilha (valores de 7 amostras compostas, 6 alíquotas por amostra, coletadas 1 vez por semana por 7 semanas consecutivas). 


\begin{tabular}{|c|c|c|c|c|}
\hline \multirow{2}{*}{ Parâmetro } & \multirow{2}{*}{ Un. } & \multicolumn{3}{|c|}{ Concentrações } \\
\hline & & Média & Máxima & Mínima \\
\hline $\begin{array}{l}\text { Oxigênio } \\
\text { Dissolvido }\end{array}$ & $(\mathrm{mg} / \mathrm{l})$ & 4,8 & 3 & 5,1 \\
\hline Sólidos Totais & $(\mathrm{mg} / \mathrm{l})$ & 590 & 665 & 499 \\
\hline $\begin{array}{c}\text { Sólidos Totais } \\
\text { Fixos }\end{array}$ & $(\mathrm{mg} / \mathrm{l})$ & 366 & 420 & 285 \\
\hline $\begin{array}{c}\text { Sólidos Totais } \\
\text { Voláteis }\end{array}$ & $(\mathrm{mg} / \mathrm{l})$ & 224 & 245 & 214 \\
\hline $\begin{array}{c}\text { Sólidos } \\
\text { Suspensos Totais }\end{array}$ & $(\mathrm{mg} / \mathrm{l})$ & 100 & 153 & 77 \\
\hline $\begin{array}{c}\text { Sólidos } \\
\text { Suspensos Fixos }\end{array}$ & $(\mathrm{mg} / \mathrm{l})$ & 13 & 19 & 8 \\
\hline $\begin{array}{l}\text { Sólidos } \\
\text { Suspensos } \\
\text { Voláteis }\end{array}$ & $(\mathrm{mg} / \mathrm{l})$ & 87 & 134 & 69 \\
\hline DQO & $(\mathrm{mg} / \mathrm{l})$ & 330 & 421 & 290 \\
\hline $\mathrm{DBO}_{5}$ & $(\mathrm{mg} / \mathrm{l})$ & 67 & 92 & 44 \\
\hline Fósforo Total & $(\mathrm{mg} / \mathrm{l})$ & 5,8 & 6,2 & 5,2 \\
\hline Condutividade & $(\mu \mathrm{s} / \mathrm{cm})$ & 777 & 892 & 568 \\
\hline $\begin{array}{l}\text { Coliformes } \\
\text { Totais }\end{array}$ & NMP & $9,2 \times 10^{6}$ & $3 \times 10^{6}$ & $1 \times 10^{6}$ \\
\hline $\begin{array}{l}\text { Coliformes } \\
\text { Fecais }\end{array}$ & NMP & $5,6 \times 10^{5}$ & $8 \times 10^{5}$ & $2 \times 10^{5}$ \\
\hline $\begin{array}{l}\text { Nitrogênio Total } \\
\text { Kjedhal }\end{array}$ & $(\mathrm{mg} / \mathrm{l})$ & 42 & 50 & 36 \\
\hline $\begin{array}{l}\text { Nitrogênio } \\
\text { Amoniacal }\end{array}$ & $(\mathrm{mg} / \mathrm{l})$ & 34 & 40 & 28 \\
\hline Nitrato $\left(\mathrm{NO}_{3}\right)$ & $(\mathrm{mg} / \mathrm{l})$ & 0,1 & 0,2 & n.d. \\
\hline
\end{tabular}


APÊNDICE E - Resultados de análises físico-químicas e bacteriológicas do esgoto efluente da lagoa de maturação durante o período de ensaio da lagoa piloto com lentilha d água (valores de 7 amostras compostas, 6 alíquotas por amostra, coletadas 1 vez por semana por 7 semanas consecutivas). 


\begin{tabular}{|c|c|c|c|c|}
\hline \multirow[b]{2}{*}{ Parâmetro } & \multicolumn{4}{|c|}{ Concentração } \\
\hline & Un. & Média & Máxima & Mínima \\
\hline Oxigênio Dissolvido & $(\mathrm{mg} / \mathrm{l})$ & 5 & 7,1 & 4,9 \\
\hline Sólidos Totais & $(\mathrm{mg} / \mathrm{l})$ & 554 & 621 & 520 \\
\hline Sólidos Totais Fixos & $(\mathrm{mg} / \mathrm{l})$ & 342 & 380 & 320 \\
\hline Sólidos Totais Voláteis & $(\mathrm{mg} / \mathrm{l})$ & 212 & 231 & 200 \\
\hline Sólidos Suspensos Totais & $(\mathrm{mg} / \mathrm{l})$ & 76 & 106 & 54 \\
\hline Sólidos Suspensos Fixos & $(\mathrm{mg} / \mathrm{l})$ & 16 & 17 & 5 \\
\hline Sólidos Suspensos Voláteis & $(\mathrm{mg} / \mathrm{l})$ & 60 & 89 & 52 \\
\hline DQO & $(\mathrm{mg} / \mathrm{l})$ & 278 & 301 & 261 \\
\hline $\mathrm{DBO}_{5}$ & $(\mathrm{mg} / \mathrm{l})$ & 63 & 71 & 60 \\
\hline Fósforo Total & $(\mathrm{mg} / \mathrm{l})$ & 6,3 & 6,8 & 5,8 \\
\hline Condutividade & $(\mu \mathrm{s} / \mathrm{cm})$ & 787 & 804 & 761 \\
\hline Coliformes Totais & NMP & $8 \times 10^{6}$ & $9 \times 10^{6}$ & $3 \times 10^{6}$ \\
\hline Coliformes Fecais & NMP & $2,9 \times 10^{5}$ & $5 \times 10^{5}$ & $1 \times 10^{5}$ \\
\hline Nitrogênio Total Kjedhal & $(\mathrm{mg} / \mathrm{l})$ & 40 & 44 & 38 \\
\hline Nitrogênio Amoniacal & $(\mathrm{mg} / \mathrm{l})$ & 26 & 29 & 21 \\
\hline Nitrato $\left(\mathrm{NO}_{3}\right)$ & $(\mathrm{mg} / \mathrm{l})$ & 1,1 & 1,4 & 0,5 \\
\hline
\end{tabular}


APÊNDICEF-Resultados de análises físico-químicas e bacteriológicas do esgoto efluente da lagoa com lentilha d'água (valores de 7 amostras compostas, 6 alíquotas por amostra, coletadas 1 vez por semana por 7 semanas consecutivas). 


\begin{tabular}{|c|c|c|c|c|}
\hline \multirow{2}{*}{ Parâmetro } & \multicolumn{4}{|c|}{ Concentração } \\
\hline & Un. & Média & Máxima & Mínima \\
\hline Oxigênio Dissolvido & $(\mathrm{mg} / \mathrm{l})$ & 5,3 & 8 & 4,4 \\
\hline Sólidos Totais & $(\mathrm{mg} / \mathrm{l})$ & 566 & 672 & 551 \\
\hline Sólidos Totais Fixos & $(\mathrm{mg} / \mathrm{l})$ & 327 & 421 & 295 \\
\hline Sólidos Totais Voláteis & $(\mathrm{mg} / \mathrm{l})$ & 239 & 251 & 224 \\
\hline Sólidos Suspensos Totais & $(\mathrm{mg} / \mathrm{l})$ & 73 & 97 & 62 \\
\hline Sólidos Suspensos Fixos & $(\mathrm{mg} / \mathrm{l})$ & 13 & 18 & 10 \\
\hline Sólidos Suspensos Voláteis & $(\mathrm{mg} / \mathrm{l})$ & 60 & 79 & 52 \\
\hline DQO & $(\mathrm{mg} / \mathrm{l})$ & 259 & 308 & 232 \\
\hline $\mathrm{DBO}_{5}$ & $(\mathrm{mg} / \mathrm{l})$ & 53 & 85 & 31 \\
\hline Fósforo Total & $(\mathrm{mg} / \mathrm{l})$ & 5,8 & 6,5 & 4,6 \\
\hline Condutividade & $(\mu \mathrm{s} / \mathrm{cm})$ & 859 & 914 & 820 \\
\hline Coliformes Totais & NMP & $8,6 \times 10^{6}$ & $9 \times 10^{6}$ & $3 \times 10^{6}$ \\
\hline Coliformes Fecais & NMP & $5,4 \times 10^{5}$ & $7,1 \times 10^{5}$ & $3 \times 10^{5}$ \\
\hline Nitrogênio Total Kjedhal & $(\mathrm{mg} / \mathrm{l})$ & 38 & 45 & 32 \\
\hline Nitrogênio Amoniacal & $(\mathrm{mg} / \mathrm{l})$ & 20 & 23 & 18 \\
\hline Nitrato $\left(\mathrm{NO}_{3}\right)$ & $(\mathrm{mg} / \mathrm{l})$ & 2,1 & 2,8 & n.d. \\
\hline
\end{tabular}


APÊNDICE G- Medidas de temperatura obtidas na lagoa sem chicaneamento ao longo do período de análise hidrodinâmica. Medidas às 16 horas de cada dia. Valores obtidos no ponto 1 (centro da lagoa) conforme FIGURA 5.5. 


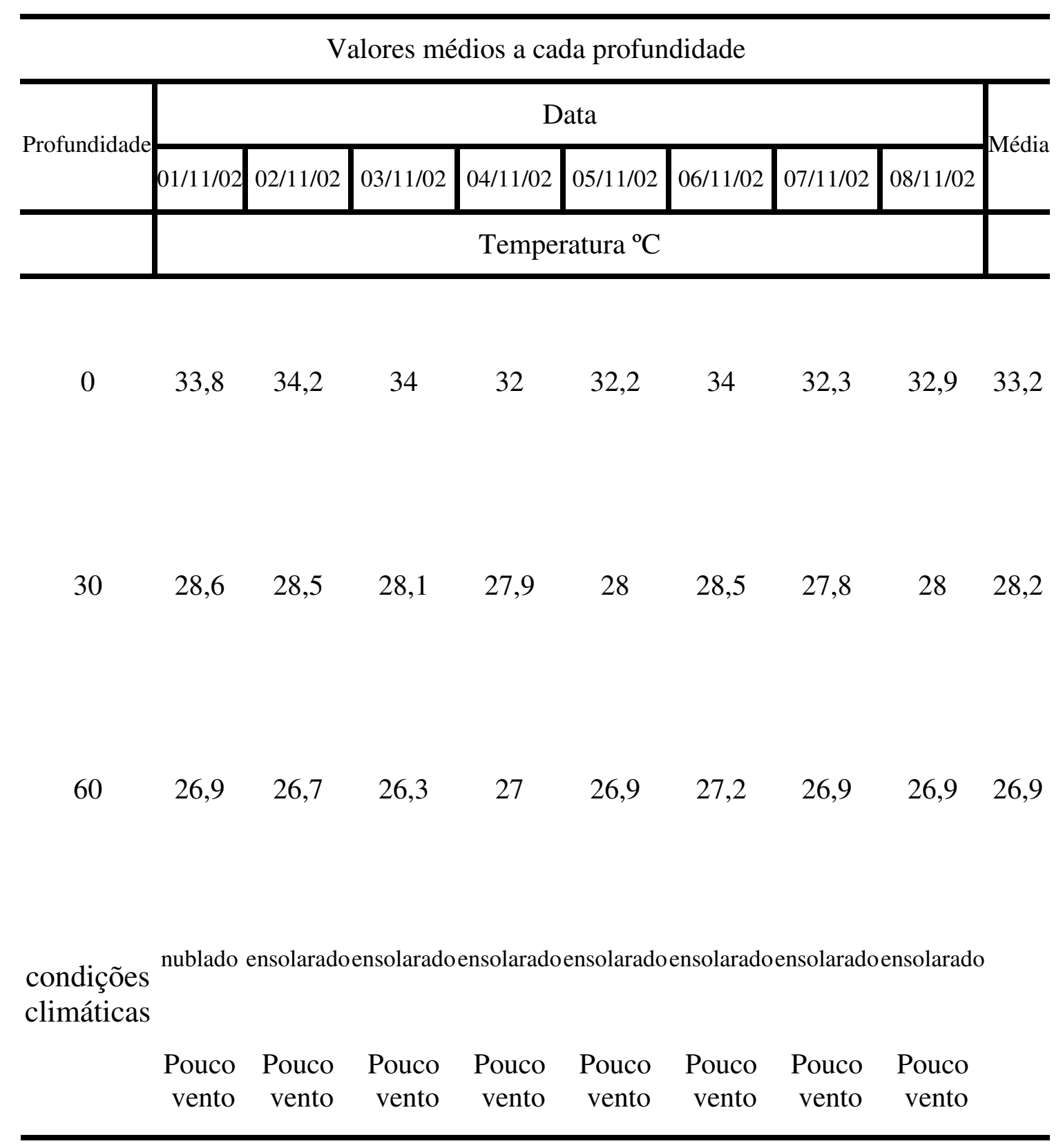


APÊNDICE H-Valores de OD na lagoa sem chicaneamento ao longo do período de análise hidrodinâmica. Medidas às 16 horas de cada dia. Valores obtidos no ponto 1 ( centro da lagoa) conforme FIGURA 5.5. 


\begin{tabular}{|c|c|c|c|c|c|c|c|c|c|}
\hline \multicolumn{10}{|c|}{ Centro da Lagoa } \\
\hline \multirow{3}{*}{ Profundidade } & \multicolumn{8}{|c|}{ Data } & \multirow{3}{*}{ Médi } \\
\hline & $01 / 11 / 02$ & $02 / 11 / 02$ & $03 / 11 / 02$ & $04 / 11 / 02$ & $05 / 11 / 02$ & $06 / 11 / 02$ & 07/11/02 & 08/11/02 & \\
\hline & \multicolumn{8}{|c|}{$\mathrm{OD}(\mathrm{mg} / \mathrm{l})$} & \\
\hline $\begin{array}{l}\text { Superfície } \\
(0,0 \mathrm{~cm})\end{array}$ & 16 & 11 & 12 & 11 & 16 & 20 & 17 & 20 & 15 \\
\hline $30 \mathrm{~cm}$ & 2 & 2 & 3 & 2 & 1 & 2 & 2 & 3 & 2 \\
\hline $60 \mathrm{~cm}$ & 0 & 0 & 0,2 & 0,4 & 0 & 0,1 & 0,3 & 0 & 0 \\
\hline
\end{tabular}


APÊNDICE I - Valores de DQO na lagoa sem chicaneamento ao longo do período de análise hidrodinâmica. Medidas às 16 horas de cada dia. Valores obtidos no ponto 1 ( centro da lagoa ) conforme FIGURA 5.5. 


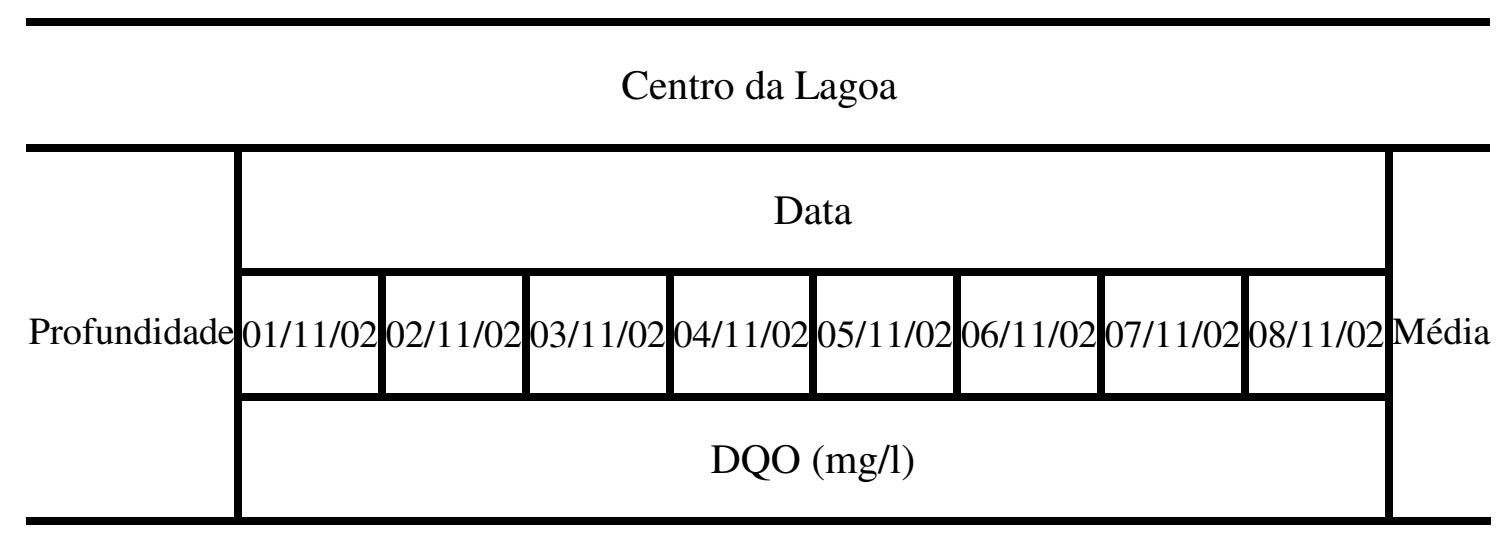

$\begin{array}{llllllllll}\text { Afluente } & 240 & 224 & 168 & 157 & 162 & 184 & 205 & 199 & 192\end{array}$

\begin{tabular}{|c|}
\hline $\begin{array}{c}\text { Superfície } \\
(0.0 \mathrm{~cm})\end{array}$ \\
\hline
\end{tabular}

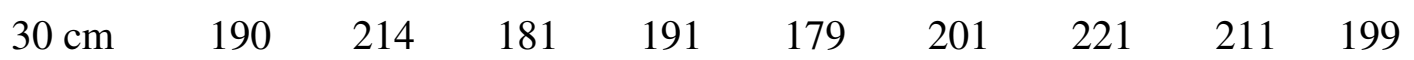

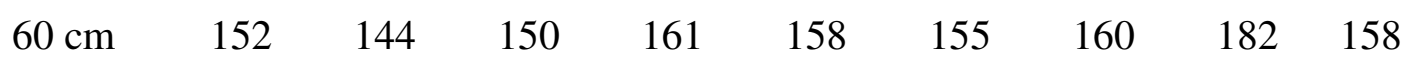


APÊNDICE J - Concentração de Rodamina obtida na lagoa sem chicaneamento ao longo do período de análise hidrodinâmica. Medidas às 16 horas de cada dia. Valores obtidos no ponto 1( centro da lagoa) conforme FIGURA 5.5. 
Valores médios a cada profundidade

\begin{tabular}{l|l|l|l|l|l|l|l}
\hline & \multicolumn{7}{|c}{ Data } \\
\cline { 2 - 7 } Profundidade & $01 / 11 / 02$ & $02 / 11 / 02$ & $03 / 11 / 02$ & $04 / 11 / 02$ & $05 / 11 / 02$ & $06 / 11 / 02$ & $07 / 11 / 02$ \\
\cline { 2 - 6 } & \multicolumn{7}{c}{ Concentração de Rodamina $(\mu \mathrm{g} / \mathrm{l})$} \\
\hline
\end{tabular}

$\begin{array}{cccccccc}\begin{array}{c}\text { Superfície } \\ (0,0 \mathrm{~cm})\end{array} & 67,0 & 44,0 & 47,0 & 28,0 & 14,0 & 10,0 & 8,0 \\ & & & & & & \\ & & & & & & \\ 30 \mathrm{~cm} & 63,0 & 48,0 & 49,0 & 23,0 & 13,0 & 9,0 & 9,0 \\ & & & & & & & \\ & & & & & & & \\ 60 \mathrm{~cm} & 61,0 & 47,0 & 46,0 & 28,0 & 16,0 & 9,0 & 9,0\end{array}$

\begin{tabular}{llcccccc} 
condições & ensolarado & ensolarado & ensolarado & ensolarado & ensolarado & ensolarado ensolarado \\
climáticas & $\begin{array}{c}\text { Pouco } \\
\text { vento }\end{array}$ & $\begin{array}{r}\text { Pouco } \\
\text { vento }\end{array}$ & $\begin{array}{r}\text { Pouco } \\
\text { vento }\end{array}$ & $\begin{array}{r}\text { Pouco } \\
\text { vento }\end{array}$ & $\begin{array}{r}\text { Pouco } \\
\text { vento }\end{array}$ & $\begin{array}{r}\text { Pouco } \\
\text { vento }\end{array}$ & $\begin{array}{r}\text { Pouco } \\
\text { vento }\end{array}$ \\
\hline
\end{tabular}


APÊNDICE K-Medidas de temperatura obtidas na lagoa com chicaneamento longitudinal ao longo do período de análise hidrodinâmica. Medidas às 16 horas de cada dia. Valores médios nos pontos 1,2 e 3 conforme FIGURA 5.12. 


\begin{tabular}{|c|c|c|c|c|c|c|c|c|c|}
\hline \multicolumn{10}{|c|}{ Chicana 1} \\
\hline \multirow{2}{*}{ Profundidade } & \multicolumn{8}{|c|}{ Data } & \multirow{2}{*}{ Média } \\
\hline & 09/12/01 & $10 / 12 / 01$ & $11 / 12 / 01$ & $12 / 12 / 01$ & $13 / 12 / 01$ & $14 / 12 / 01$ & $15 / 12 / 01$ & $16 / 12 / 01$ & \\
\hline $\mathrm{cm}$ & \multicolumn{8}{|c|}{ Temperatura ${ }^{\circ} \mathrm{c}$} & \\
\hline 0 & 30,1 & 32,4 & 36,3 & 35,8 & 35,8 & 34,8 & 35,5 & 39,6 & 35,0 \\
\hline 30 & 29,3 & 26,6 & 27,2 & 27,6 & 28,6 & 27,2 & 26,8 & 28,2 & 27,6875 \\
\hline 60 & 27,8 & 26,3 & 26,7 & 27 & 27,2 & 25 & 25,9 & 26,7 & 26,575 \\
\hline
\end{tabular}

\begin{tabular}{|c|c|c|c|c|c|c|c|c|c|}
\hline \multicolumn{10}{|c|}{ Chicana 2} \\
\hline \multirow{2}{*}{ Profundidade } & \multicolumn{8}{|c|}{ Data } & \multirow{2}{*}{ Média } \\
\hline & 09/12/01 & $10 / 12 / 01$ & $11 / 12 / 01$ & $12 / 12 / 01$ & $13 / 12 / 01$ & $14 / 12 / 01$ & $15 / 12 / 01$ & $16 / 12 / 01$ & \\
\hline $\mathrm{cm}$ & \multicolumn{8}{|c|}{ Temperatura ${ }^{\circ} \mathrm{c}$} & \\
\hline 0 & 30,5 & 32,5 & 36 & 34,8 & 34,3 & 34,8 & 35,2 & 38,2 & 34,5 \\
\hline 30 & 29,1 & 26,6 & 26,8 & 27,7 & 27,8 & 26 & 26,9 & 28,3 & 27,4 \\
\hline 60 & 27,8 & 26,3 & 26,3 & 26,8 & 27,2 & 25,9 & 26,4 & 26,7 & 26,7 \\
\hline
\end{tabular}

\begin{tabular}{|c|c|c|c|c|c|c|c|c|c|}
\hline \multicolumn{10}{|c|}{ Chicana 3} \\
\hline \multirow{2}{*}{ Profundidade } & \multicolumn{8}{|c|}{ Data } & \multirow{2}{*}{ Média } \\
\hline & $09 / 12 / 01$ & $10 / 12 / 01$ & $11 / 12 / 01$ & $12 / 12 / 01$ & $13 / 12 / 01$ & $14 / 12 / 01$ & $15 / 12 / 01$ & $16 / 12 / 01$ & \\
\hline $\mathrm{cm}$ & \multicolumn{8}{|c|}{ Temperatura ${ }^{\circ} \mathrm{C}$} & \\
\hline 0 & 30,4 & 32,3 & 36,2 & 35,1 & 34,3 & 35 & 35,1 & 38,5 & 34,6 \\
\hline 30 & 29,1 & 26,6 & 27,1 & 27,8 & 28,4 & 26,9 & 26,8 & 28,5 & 27,7 \\
\hline 60 & 27,9 & 26,4 & 26,3 & 27 & 27,2 & 26 & 26,1 & 26,8 & 26,7 \\
\hline
\end{tabular}

\begin{tabular}{|c|c|c|c|c|c|c|c|c|c|}
\hline \multicolumn{10}{|c|}{ Valores médios a cada profundidade } \\
\hline \multirow{2}{*}{ Profundidade } & \multicolumn{8}{|c|}{ Data } & \multirow{2}{*}{ Média } \\
\hline & 09/12/01 & $10 / 12 / 01$ & $11 / 12 / 01$ & $12 / 12 / 01$ & $13 / 12 / 01$ & $14 / 12 / 01$ & $15 / 12 / 01$ & $16 / 12 / 01$ & \\
\hline $\mathrm{cm}$ & \multicolumn{8}{|c|}{ Temperatura ${ }^{\circ} \mathrm{C}$} & \\
\hline 0 & 30,3 & 32,4 & 36,2 & 35,2 & 34,8 & 34,9 & 35,3 & 38,8 & 34,7 \\
\hline 30 & 29,2 & 26,6 & 27,0 & 27,7 & 28,3 & 26,7 & 26,8 & 28,3 & 27,6 \\
\hline 60 & 27,8 & 26,3 & 26,4 & 26,9 & 27,2 & 25,6 & 26,1 & 26,7 & 26,7 \\
\hline
\end{tabular}

condições nublado ensolaradoensolarado ensolarado ensolaradoensolaradoensolaradoensolarado climáticas

Pouco Pouco Pouco Pouco Pouco Pouco Pouco Pouco vento vento vento vento vento vento vento vento 
APÊNDICEL-Valores de OD na lagoa com chicaneamento longitudinal ao longo do período de análise hidrodinâmica. Medidas às 16 horas de cada dia . Valores obtidos no ponto 2 conforme FIGURA 5.12. 


\section{CHICANA 2 / PONTO 2}

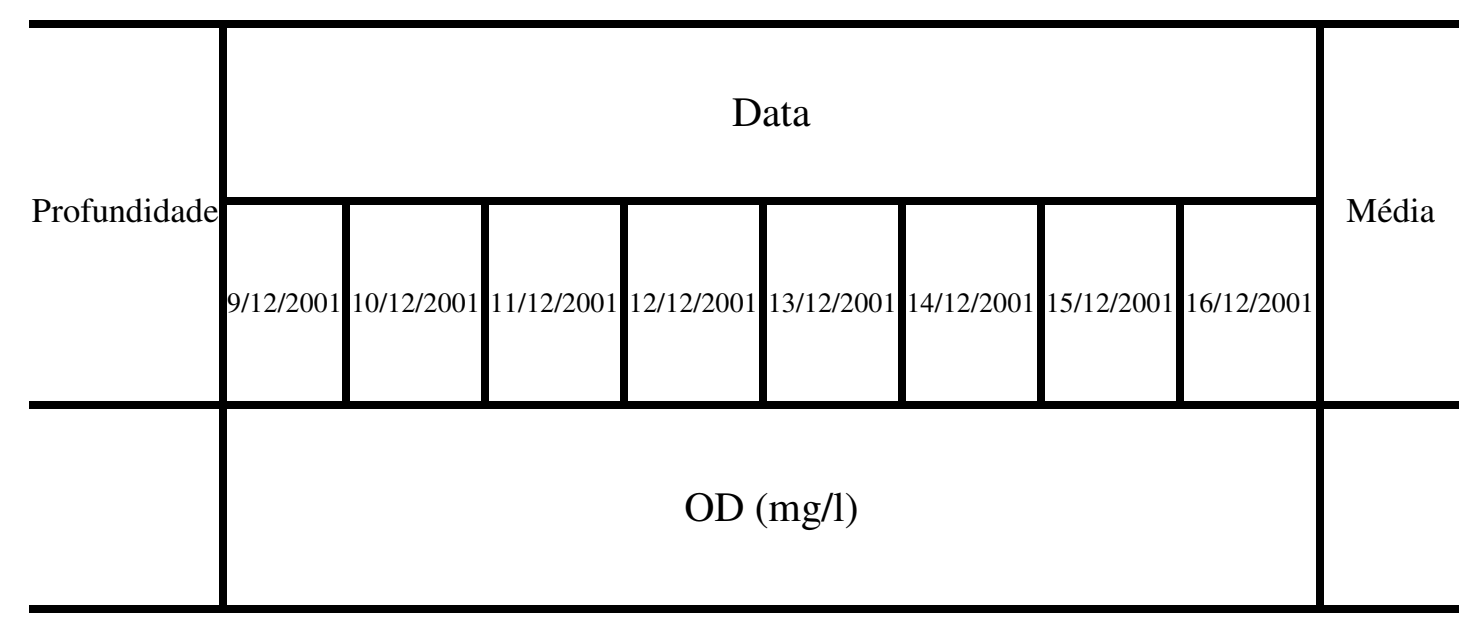

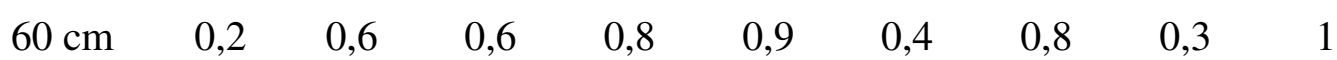

$\begin{array}{llllllllll}30 \mathrm{~cm} & 2 & 3 & 2 & 2 & 1 & 1 & 1 & 2 & 2\end{array}$

$\begin{array}{cccccccccc}\begin{array}{c}\text { Superfície } \\ (0,0 \mathrm{~cm})\end{array} & 14 & 12 & 16 & 15 & 20 & 18 & 16 & 14 & 16\end{array}$ 
APÊNDICEM - Valores de DQO na lagoa com chicaneamento longitudinal ao longo do período de análise hidrodinâmica. Medidas às 16 horas cada dia . Valores obtidos no ponto 2 conforme FIGURA 5.12. 
CHICANA 2

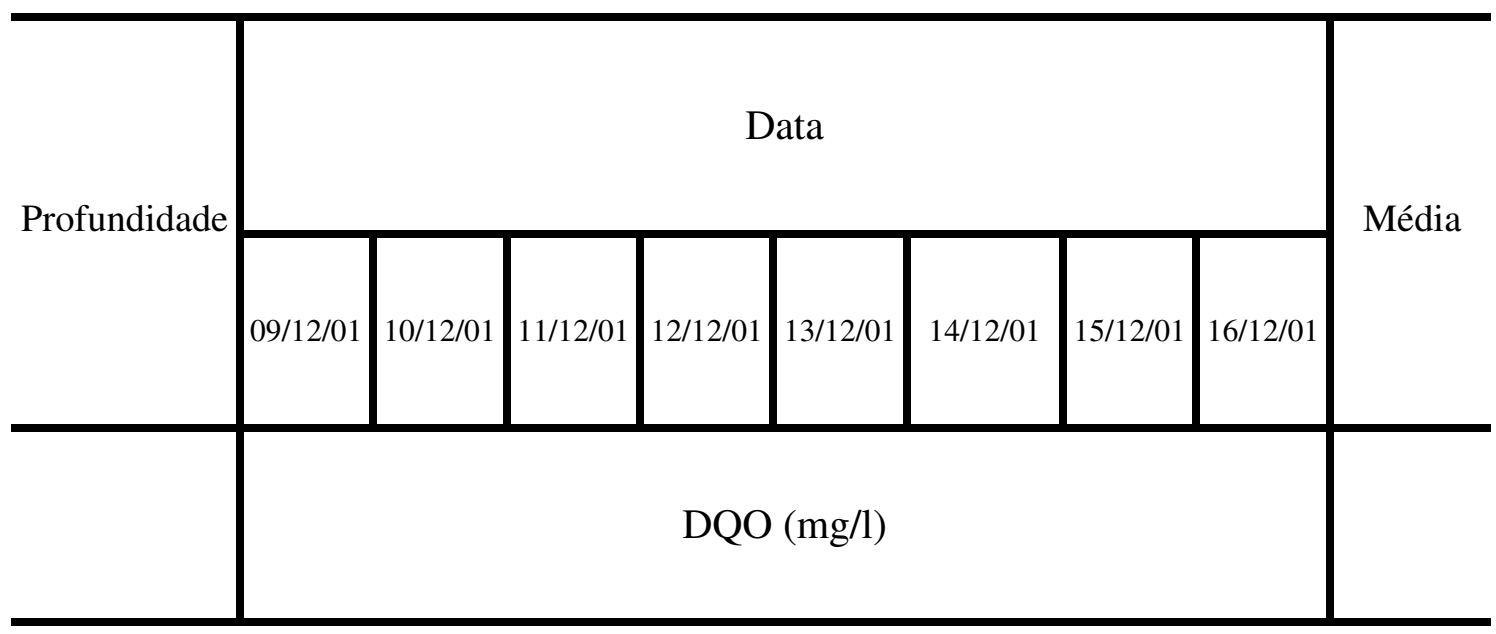

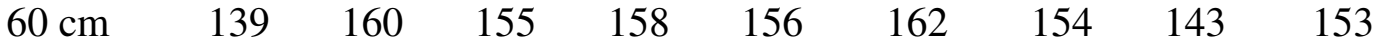

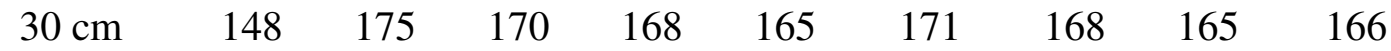

$\begin{array}{clllllllll}\begin{array}{c}\text { Superfície } \\ (0,0 \mathrm{~cm})\end{array} & 122 & 154 & 138 & 142 & 133 & 146 & 144 & 139 & 140\end{array}$

$\begin{array}{llllllllll}\text { Afluente } & 186 & 205 & 192 & 238 & 161 & 189 & 232 & 290 & 212\end{array}$ 
APÊNDICE N - Concentração de Rodamina obtida na lagoa com chicaneamento longitudinal ao longo do período de análise hidrodinâmica. Medidas às 16 horas de cada dia . Valores obtidos nos pontos 1,2 e 3 conforme FIGURA 5.12. 


\begin{tabular}{c|c|c|c|c|c|c|c}
\hline \multicolumn{7}{c}{ CHICANA 1 } \\
\hline \multirow{2}{*}{ Profundidade } & \multicolumn{7}{c}{ Data } \\
\cline { 2 - 8 } & $09 / 12 / 01$ & $10 / 12 / 01$ & $11 / 12 / 01$ & $12 / 12 / 01$ & $13 / 12 / 01$ & $14 / 12 / 01$ & $15 / 12 / 01$ \\
\hline $\mathrm{cm}$ & 87 & 68 & 52 & 41 & 24 & 11 & 5 \\
\hline 0 & 70 & 53 & 39 & 31 & 16 & 8 & 2 \\
30 & 85 & 60 & 49 & 34 & 15 & 6 & 4 \\
60 & & & & & 6 & & \\
\hline
\end{tabular}

\begin{tabular}{c|c|c|c|c|c|c|c}
\hline \multicolumn{7}{c}{ CHICANA 2 } \\
\hline \multirow{2}{*}{ Profundidade } & \multicolumn{7}{c}{ Data } \\
\cline { 2 - 8 } & $09 / 12 / 01$ & $10 / 12 / 01$ & $11 / 12 / 01$ & $12 / 12 / 01$ & $13 / 12 / 01$ & $14 / 12 / 01$ & $15 / 12 / 01$ \\
\hline $\mathrm{cm}$ & 74 & 60,5 & 45,8 & 23,6 & 12,6 & 2,7 \\
\hline 0 & 78,5 & 74,6 Concentração de Rodamina $(\mu \mathrm{g} / 1)$ \\
30 & 74,5 & 57,3 & 41,7 & 32,7 & 15,7 & 5,9 & 1,1 \\
60 & 86,2 & 69,1 & 59,2 & 42,4 & 17,2 & 5 & 3,5 \\
\hline
\end{tabular}

\begin{tabular}{c|ccc|cc|ccc}
\hline \multicolumn{7}{c}{ CHICANA 3 } \\
\hline \multirow{2}{*}{ Profundidade } & \multicolumn{7}{c}{ Data } \\
\cline { 2 - 8 } & $09 / 12 / 01$ & $10 / 12 / 01$ & $11 / 12 / 01$ & $12 / 12 / 01$ & $13 / 12 / 01$ & $14 / 12 / 01$ & $15 / 12 / 01$ \\
\hline $\mathrm{cm}$ & 66,37 & 78 & 63 & 50,8 & 26,6 & 13,8 & 3,3 \\
\hline 0 & 78,3 & 65,7 & 45,2 & 32,6 & 15,2 & 5,1 & 2,8 \\
30 & 75,1 & 79,9 & 61,9 & 44,6 & 22,9 & 7,5 & 2,2 \\
60 & 78 Concentração de Rodamina $(\mu \mathrm{g} / 1)$ \\
\hline
\end{tabular}

Valores médios a cada profundidade

\begin{tabular}{c|c|c|c|c|c|c|c}
\hline \multirow{2}{*}{ Profundidade } & \multicolumn{7}{c}{ Data } \\
\cline { 2 - 8 } & $09 / 12 / 01$ & $10 / 12 / 01$ & $11 / 12 / 01$ & $12 / 12 / 01$ & $13 / 12 / 01$ & $14 / 12 / 01$ & $15 / 12 / 01$ \\
\hline $\mathrm{cm}$ & 77,3 & 73,3 & 58,5 & 45,9 & 24,7 & 12,5 & 3,7 \\
\hline 0 & 74,3 & 58,7 & 42,0 & 32,1 & 15,6 & 6,3 & 2,0 \\
30 & 82,1 & 69,7 & 56,7 & 40,3 & 18,4 & 6,2 & 3,2 \\
60 & ensolarado & ensolarado & ensolarado & ensolarado & ensolarado & ensolarado & ensolarado \\
condições & Pouco & Pouco & Pouco & Pouco & Pouco & Pouco & Pouco \\
climáticas & vento & vento & vento & vento & vento & vento & vento \\
\hline
\end{tabular}


APÊNDICE O-Medidas de temperatura obtidas na lagoa com chicaneamento longitudinal e transversal ao longo do período de análise hidrodinâmica. Medidas às 16 horas de cada dia. Valores médios dos pontos 1,2 e 3 conforme FIGURA 5.19. 


\begin{tabular}{|c|c|c|c|c|c|c|c|c|c|}
\hline \multicolumn{10}{|c|}{ CHICANA 1} \\
\hline \multirow{2}{*}{ Profundidade } & \multicolumn{8}{|c|}{ Data } & \multirow{2}{*}{ Média } \\
\hline & $25 / 06 / 02$ & $26 / 06 / 02$ & $27 / 06 / 02$ & $28 / 06 / 02$ & $29 / 06 / 02$ & $30 / 06 / 02$ & $01 / 07 / 02$ & $02 / 07 / 02$ & \\
\hline $\mathrm{cm}$ & \multicolumn{9}{|c|}{ Temperatura $^{\circ} \mathrm{C}$} \\
\hline 0 & 34,8 & 37,7 & 31,8 & 29,8 & 30,4 & 32,1 & 35,4 & 34,4 & 33,3 \\
\hline 30 & 28,1 & 28,6 & 28,2 & 27,3 & 27 & 27,1 & 27,5 & 27,7 & 27,6875 \\
\hline 60 & 27,6 & 27,4 & 27,5 & 27,1 & 26,1 & 26,6 & 26,8 & 26,7 & 26,975 \\
\hline
\end{tabular}

\begin{tabular}{|c|c|c|c|c|c|c|c|c|c|}
\hline \multicolumn{10}{|c|}{ CHICANA 2} \\
\hline \multirow[b]{2}{*}{ Profundidade } & \multicolumn{8}{|c|}{ Data } & \multirow[b]{2}{*}{ Média } \\
\hline & $25 / 06 / 02$ & $26 / 06 / 02$ & $27 / 06 / 02$ & $28 / 06 / 02$ & $29 / 06 / 02$ & $30 / 06 / 02$ & $01 / 07 / 02$ & $02 / 07 / 02$ & \\
\hline $\mathrm{cm}$ & \multicolumn{9}{|c|}{ Temperatura ${ }^{\circ} \mathrm{C}$} \\
\hline 0 & 34,7 & 37 & 31,5 & 29,7 & 30,4 & 31,8 & 35,2 & 33,8 & 33,0 \\
\hline 30 & 29,3 & 28,8 & 28 & 27,4 & 26,6 & 27,1 & 27,3 & 27,4 & 27,7375 \\
\hline 60 & 28,2 & 28,1 & 27,5 & 27 & 26,1 & 26,7 & 26,8 & 26,6 & 27,1 \\
\hline
\end{tabular}

\begin{tabular}{|c|c|c|c|c|c|c|c|c|c|}
\hline \multicolumn{10}{|c|}{ CHICANA 3} \\
\hline \multirow{2}{*}{ Profundidade } & \multicolumn{8}{|c|}{ Data } & \multirow{2}{*}{ Média } \\
\hline & $25 / 06 / 02$ & $26 / 06 / 02$ & $27 / 06 / 02$ & 28/06/02 & $29 / 06 / 02$ & $30 / 06 / 02$ & $01 / 07 / 02$ & $02 / 07 / 02$ & \\
\hline $\mathrm{cm}$ & \multicolumn{9}{|c|}{ Temperatura ${ }^{\circ} \mathrm{C}$} \\
\hline 0 & 34,2 & 36,8 & 31,2 & 29,7 & 30,2 & 32 & 35,1 & 34,5 & 33,0 \\
\hline 30 & 28,9 & 28,5 & 28,2 & 27,8 & 26,1 & 26,9 & 26,8 & 28,2 & 27,7 \\
\hline 60 & 27,9 & 26,9 & 27,1 & 27 & 26,4 & 26,9 & 26,1 & 26,8 & 26,9 \\
\hline
\end{tabular}

\begin{tabular}{|c|c|c|c|c|c|c|c|c|c|}
\hline \multicolumn{10}{|c|}{ Valores médios a cada profundidade } \\
\hline \multirow{2}{*}{ Profundidade } & \multicolumn{8}{|c|}{ Data } & \multirow{2}{*}{ Média } \\
\hline & $25 / 06 / 02$ & $26 / 06 / 02$ & $27 / 06 / 02$ & $28 / 06 / 02$ & $29 / 06 / 02$ & $30 / 06 / 02$ & $01 / 07 / 02$ & $02 / 07 / 02$ & \\
\hline $\mathrm{cm}$ & \multicolumn{9}{|c|}{ Temperatura $^{\circ} \mathrm{C}$} \\
\hline 0 & 34,6 & 37,2 & 31,5 & 29,7 & 30,3 & 32,0 & 35,2 & 34,2 & 33,1 \\
\hline 30 & 28,8 & 28,6 & 28,1 & 27,5 & 26,6 & 27,0 & 27,2 & 27,8 & 27,7 \\
\hline 60 & 27,9 & 27,5 & 27,4 & 27,0 & 26,2 & 26,7 & 26,6 & 26,7 & 27,0 \\
\hline
\end{tabular}

ensolaradoensolarado nublado chuva nublado nublado ensolaradoensolarado

condições

climáticas

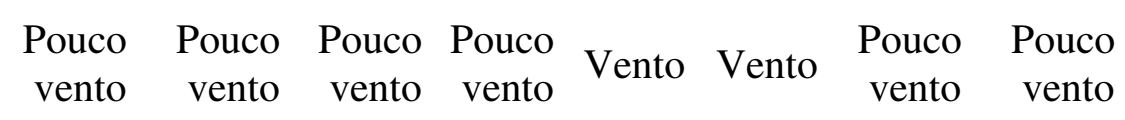


APÊNDICE P - Valores de OD na lagoa com chicaneamento longitudinal e transversal ao longo do período de análise hidrodinâmica. Medidas às 16 horas de cada dia. Valores obtidos nos pontos 2 conforme FIGURA 5.12. 
CHICANA 2

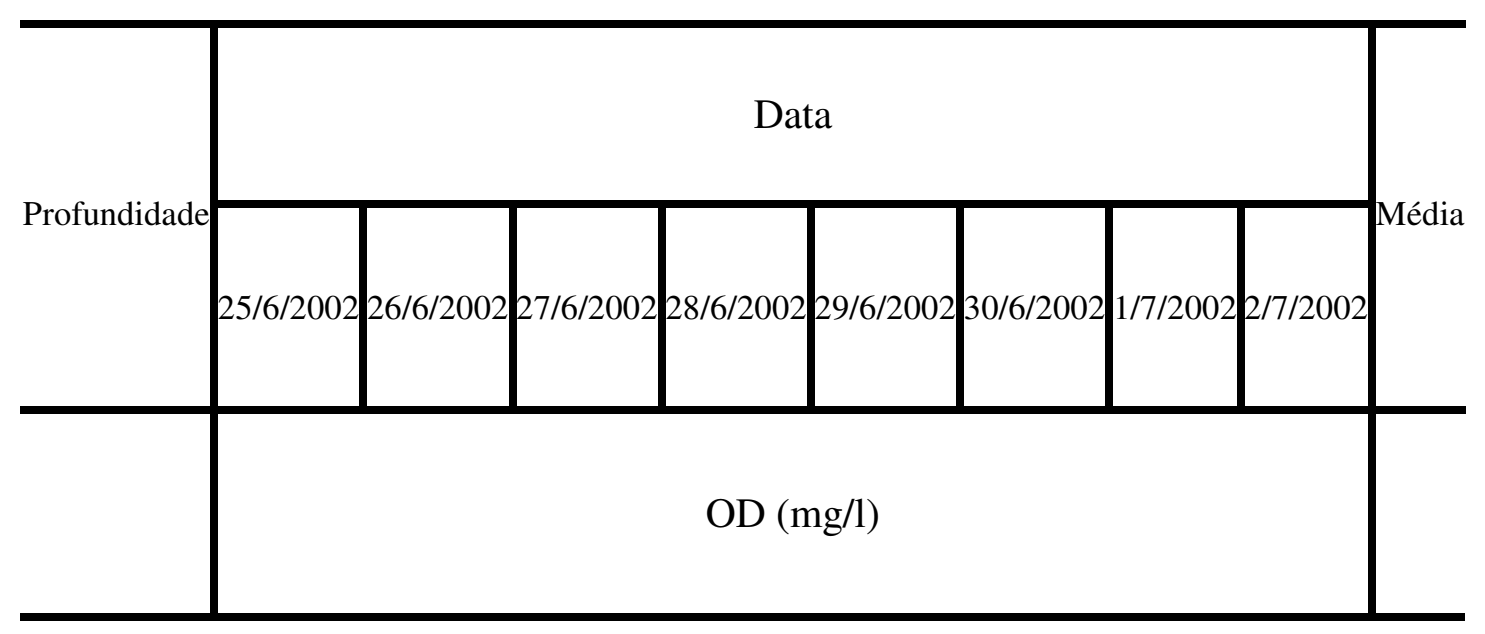

$\begin{array}{llllllllll}60 \mathrm{~cm} & 0,6 & 0,5 & 0 & 0 & 0,3 & 0 & 0,5 & 0 & 0\end{array}$

$\begin{array}{llllllllll}30 \mathrm{~cm} & 3 & 3 & 2 & 2 & 1 & 1 & 3 & 2 & 2\end{array}$

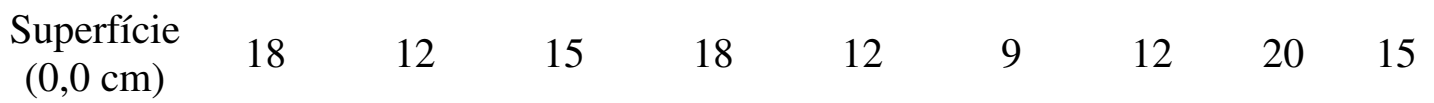


APÊNDICEQ-Valores de DQO na lagoa com chicaneamento longitudinal e transversal ao longo do período de análise hidrodinâmica. Medidas às 16 horas de cada dia. Valores obtidos no ponto 2 conforme FIGURA 5.19. 


\section{CHICANA 2}

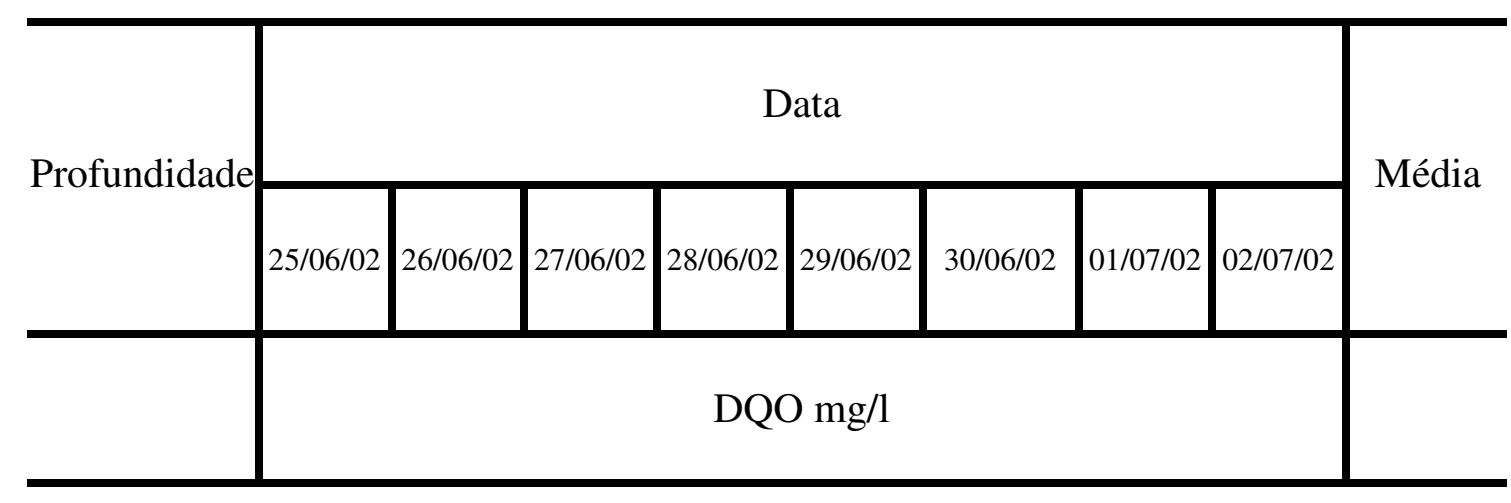

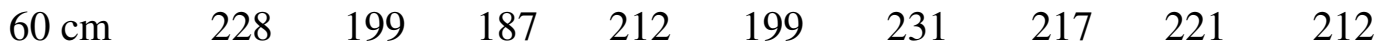

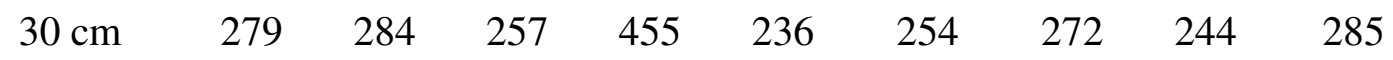

$\begin{array}{clllllllll}\begin{array}{c}\text { Superfície } \\ (0,0 \mathrm{~cm})\end{array} & 261 & 209 & 167 & 273 & 185 & 148 & 179 & 191 & 202\end{array}$

$\begin{array}{llllllllll}\text { Afluente } & 238 & 251 & 286 & 389 & 244 & 259 & 212 & 221 & 263\end{array}$ 


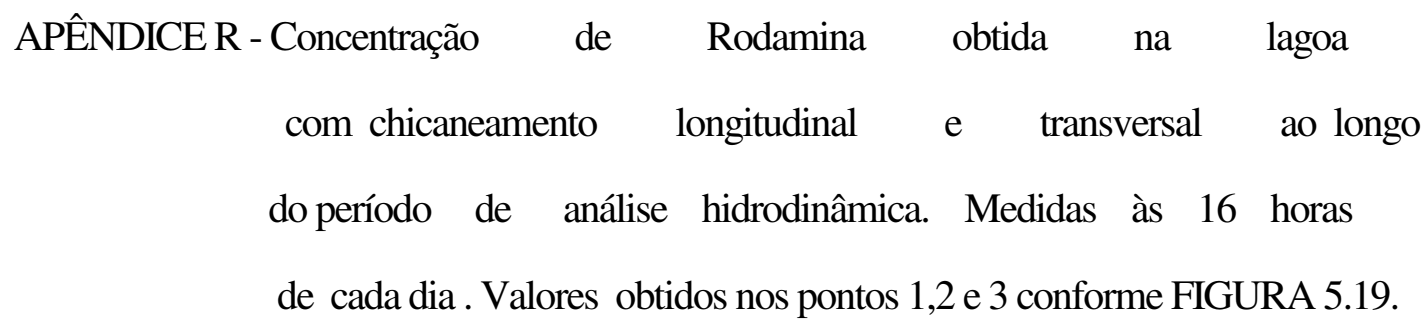




\begin{tabular}{|c|c|c|c|c|c|c|c|}
\hline \multicolumn{8}{|c|}{ CHICANA 1} \\
\hline \multirow{2}{*}{ Profundidade } & \multicolumn{7}{|c|}{ Data } \\
\hline & $25 / 06 / 02$ & $26 / 06 / 02$ & $27 / 06 / 02$ & $28 / 06 / 02$ & $29 / 06 / 02$ & $30 / 06 / 02$ & 01/07/02 \\
\hline $\mathrm{cm}$ & \multicolumn{7}{|c|}{ Concentração de Rodamina $(\mu \mathrm{g} / \mathrm{l})$} \\
\hline 0 & 62 & 66 & 30 & 8 & 2 & 0 & 0 \\
\hline 30 & 43 & 44 & 25 & 5 & 0,5 & 0,6 & 0,6 \\
\hline 60 & 39 & 46 & 32 & 10 & 6 & 0,2 & 0 \\
\hline \multicolumn{8}{|c|}{ CHICANA 2} \\
\hline \multirow{2}{*}{ Profundidade } & \multicolumn{7}{|c|}{ Data } \\
\hline & $25 / 06 / 02$ & $26 / 06 / 02$ & $27 / 06 / 02$ & $28 / 06 / 02$ & $29 / 06 / 02$ & $30 / 06 / 02$ & 01/07/02 \\
\hline $\mathrm{cm}$ & \multicolumn{7}{|c|}{ Concentração de Rodamina $(\mu \mathrm{g} / \mathrm{l})$} \\
\hline 0 & 64 & 59 & 38 & 14 & 6 & 2 & 1 \\
\hline 30 & 41 & 48 & 26 & 11 & 5 & 2 & 1 \\
\hline 60 & 38 & 48 & 32 & 12 & 9 & 1 & 1 \\
\hline \multicolumn{8}{|c|}{ CHICANA 3} \\
\hline \multirow{2}{*}{ Profundidade } & \multicolumn{7}{|c|}{ Data } \\
\hline & $25 / 06 / 02$ & $26 / 06 / 02$ & $27 / 06 / 02$ & $28 / 06 / 02$ & $29 / 06 / 02$ & $30 / 06 / 02$ & 01/07/02 \\
\hline $\mathrm{cm}$ & \multicolumn{7}{|c|}{ Concentração de Rodamina $(\mu \mathrm{g} / \mathrm{l})$} \\
\hline 0 & 60 & 58 & 36 & 24 & 8 & 6 & 2 \\
\hline 30 & 37 & 44 & 31 & 17 & 7 & 3 & 2 \\
\hline 60 & 34 & 38 & 23 & 15 & 8 & 4 & 1 \\
\hline \multicolumn{8}{|c|}{ Valores médios a cada profundidade } \\
\hline \multirow{2}{*}{ Profundidade } & \multicolumn{7}{|c|}{ Data } \\
\hline & $25 / 06 / 02$ & $26 / 06 / 02$ & $27 / 06 / 02$ & $28 / 06 / 02$ & $29 / 06 / 02$ & $30 / 06 / 02$ & 01/07/02 \\
\hline $\mathrm{cm}$ & \multicolumn{7}{|c|}{ Concentração de Rodamina $(\mu \mathrm{g} / \mathrm{l})$} \\
\hline 0 & 62,0 & 61,0 & 34,7 & 15,3 & 5,3 & 2,7 & 1,0 \\
\hline 30 & 40,3 & 45,3 & 27,3 & 11,0 & 4,2 & 1,9 & 1,2 \\
\hline 60 & 37,0 & 44,0 & 29,0 & 12,3 & 7,7 & 1,7 & 0,7 \\
\hline condições & ensolarado & ensolarado & nublado & chuva & nublado & nublado & ensolarado \\
\hline climáticas & $\begin{array}{c}\text { Pouco } \\
\text { vento }\end{array}$ & $\begin{array}{l}\text { Pouco } \\
\text { vento }\end{array}$ & $\begin{array}{l}\text { Pouco } \\
\text { vento }\end{array}$ & vento & vento & $\begin{array}{c}\text { Pouco } \\
\text { vento }\end{array}$ & $\begin{array}{c}\text { Pouco } \\
\text { vento }\end{array}$ \\
\hline
\end{tabular}


APÊNDICE S - Realização dos ensaios de fluorescência 


\section{1-REALIZAÇÃO DOS ENSAIOS DE FLUORESCÊNCIA}

O método apresentado é descrito pelo fluxograma (1) que demonstra as várias etapas a serem considerados entre a injeção do traçador e a coleta e tratamento dos dados no ensaio de hidrodinâmica em lagoas de estabilização.

Os procedimentos citados baseiam-se na entrada do sinal em forma de pulso, ou seja, fornece-se à entrada da corrente fluida um sinal pulsante ideal do traçador que é chamada de estimulo e obtém-se como resposta um registro de concentrações, em função dos tempos de residência do traçador no efluente. O corante mais utilizado e o considerado neste estudo é a Rodamina WT .

\subsection{Cálculo da quantidade de corante}

O cálculo para a quantidade de Rodamina WT necessária para o ensaio em lagoas de estabilização relaciona-se com nível mínimo de detecção do fluorômetro que é, para os aparelhos mais simples e comumente utilizados neste tipo de ensaio, na ordem de $2 \mu \mathrm{g} / \mathrm{l}$ (WILSON,1996; DOREGO e LEDUC,1996).

Outro fato a considerar é a relação entre o Cmin e a concentração inicial Co (Massa de corante injetada / volume lagoa, $\mu \mathrm{g} / \mathrm{l}$ ) que de acordo com COSSIO (1993) situa-se em torno de 8 para lagoas de estabilização.

A quantidade de Rodamina WT, necessária para a prova de traçadores é dada pela equação: 


$$
W=\frac{C \min \times K \times V}{1000 \times P} \quad(\mathrm{ml})
$$

$\mathrm{W}$ = Volume de solução de Rodamina WT em ml

Cmin $=$ Nível mínimo de detecção do traçador ao final do ensaio $=2 \mu \mathrm{g} / \mathrm{l}$

$\mathrm{K}=$ Relação $\mathrm{Co} / \mathrm{Cmin}=8$ para Rodamina WT em lagoa de estabilização

$\mathrm{P}=\%$ de Rodamina na solução líquida, fração decimal (usualmente 0,2 )

$\mathrm{V}=$ Volume da lagoa $\mathrm{em}^{3}$

\subsection{Homogeneização do Traçador e Termo-Adequação}

Segundo TORRES (1997) antes de adicionar à lagoa, a Rodamina WT deve ser dissolvida em volume de água de aproximadamente 5 litros para facilitar a rápida homogeneização e distribuição no efluente. $\mathrm{O}$ frasco, com a solução traçadora deve ser imerso na caixa de distribuição afluente por um período mínimo de 16 horas antes do lançamento para que a temperatura da solução alcance a temperatura do afluente.

\subsection{Aplicação do Traçador}

O traçador deve ser aplicado lançando-o rapidamente na vazão afluente através de único pulso (LEVENSPIEL, 1974; TORRES, 1997).

\subsection{Coleta de Amostras}

Segundo DOREGO e LEDUC (1996), as amostras devem ser coletadas no efluente em iguais intervalos de tempos. Os intervalos devem ser mais freqüentes até 02 dias após à injeção do traçador, se tornando menos freqüentes depois desse período. O período de coleta deve ser no mínimo 2 vezes o tempo de detenção hidráulico teórico.

SIMI e MITCHELL (1999) em seu estudo sobre lagoas de estabilização para tratamento de efluentes em refinaria de petróleo consideraram como período de coleta de amostras 3 vezes o tempo de detenção hidráulico teórico. 
Segundo COSSIO (1993) a solução contendo o traçador deve ser jogado de forma pontual junto com o afluente e a partir daí deve-se iniciar a coleta e análise das amostras em intervalos curtos de tempo (5 a $15 \mathrm{~min}$ ) até que se registre o pico da curva e posteriormente é necessário somente uma amostra pontual diária há mesmo hora, por um período de 2 a 3 vezes o tempo de detenção hidráulico teórico.

Para melhores resultados as amostras devem ser mantidas acondicionadas em ambiente escuro e frascos de vidro durante 24 horas antes de realizar os testes para garantir a homogeneização da temperatura (WILSON,1986). As amostras com alta turbidez ou com elevada concentração de algas devem ser preferencialmente centrifugadas (COSSIO,1993).

Polietieleno e Borracha são conhecidas por absorver corantes, portanto deve se utilizar somente frascos e tampas de vidro para coleta de amostras (WILSON, 1986).

\subsection{Porcentagem de Recuperação do Traçador}

O calculo da porcentagem de recuperação do traçador é muito importante para determinar a validade do experimento. Segundo COSSIO ( 1993 ) é necessário obter recuperações acima de $85 \%$.

O calculo da \% de recuperação do corante se efetua através da seguinte equação:

$$
\text { \%recuperação }=\frac{\sum C i \times \Delta t \times 60 b \times Q_{2}}{V r \times C r \times 0,01}
$$

$\sum C i$ - Somatória das concentrações obtidas no ensaio (mg/l)

$\Delta t$ - Intervalo de tempo usando no processamento (minutos ou horas)

$\mathrm{Q}_{2}$ - Vazão afluente $\left(\mathrm{m}^{3} / \mathrm{s}\right)$

$\mathrm{Vr}$ - Volume do corante (1)

$\mathrm{Cr}$ - Concentração do corante (mg/l)

$\mathrm{B}-$ coeficiente $-\mathrm{b}=1$ para $\Delta t$ em minutos

$\mathrm{b}=2$ para $\Delta t$ em horas 


\section{2-TRATAMENTO MATEMÁTICO PARA CARACTERIZAÇÃO HIDRODINÂMICA DE LAGOAS}

O tratamento matemático dos dados pode ser realizado por diversos métodos, neste trabalho em particular utilizou-se para a caracterização hidrodinâmica da lagoa, o método proposto por LEVENSPIEL (1974) e o método proposto por REBHUN e ARGAMAN (1965) conforme fluxograma 2.

\subsection{Método de Levenspiel}

Segundo LEVENSPIEL (1974) a partir do gráfico Co x $\theta$, é possível determinar os seguintes fatores:

a - características do escoamento do volume ativo da lagoa

escoamento tubular $\mathrm{d}=0$

quantidade intermediaria de dispersão $\mathrm{d}=0,025$

quantidade grande de dispersão $\mathrm{d}=0,20$

escoamento em mistura completa $\mathrm{d}=\infty$

$\mathrm{b}$ - existência de curto-circuito em escoamento em mistura completa

curvas com picos muito maiores que $\operatorname{Co}=1$ e antes de $\theta=1$ indicam a presença de curto circuito

curvas com picos próximos de $\mathrm{Co}=1$ e antes de $\theta=1$ indicam que não há presença de curto circuito.

$\mathrm{c}-$ tempo de detenção hidráulico real $=\mathrm{tm}$ 


\subsection{Método de REBHUN e ARGAMAN (1965)}

O método proposto por REBHUN e ARGAMAN (1965) indica diretamente a porcentagem da lagoa que opera em mistura completa, a porcentagem que opera em pistonado e a porcentagem de volume morto.

$\rightarrow \quad$ Fluxograma (1) - Ensaio de fluorescência em lagoas de estabilização

1

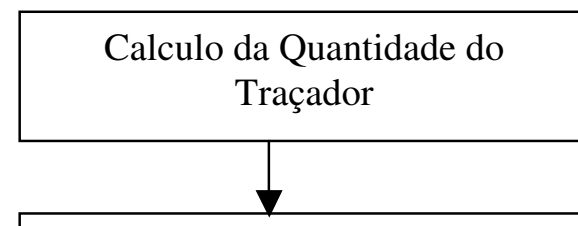

2

Homogeneização do Traçador e Termo Adequação

3
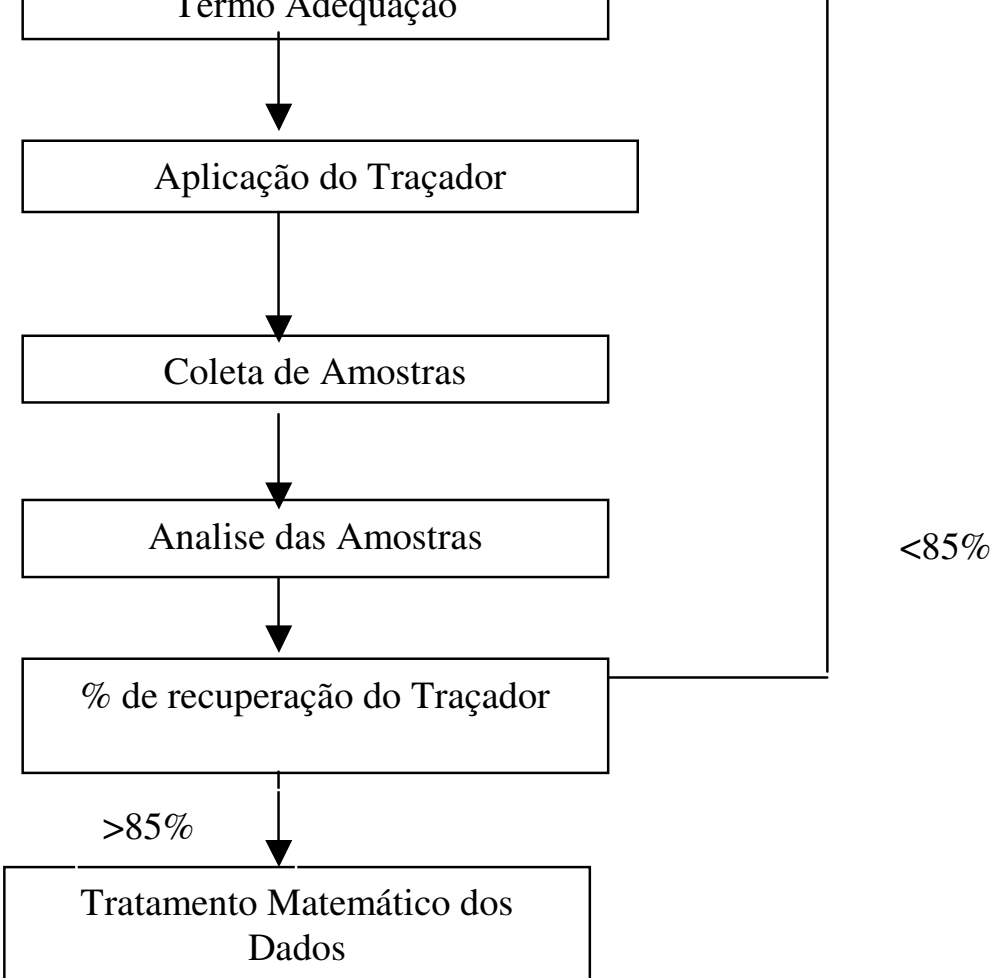

4

5

7 Dados

Resultados

- Número de Dispersão (d)

- Comportamento Hidráulico

- Coeficiente Cinético de Degradação de DBO 
$\rightarrow \quad$ Fluxograma (2) - Tratamento matemático dos dados das analises de fluorescência

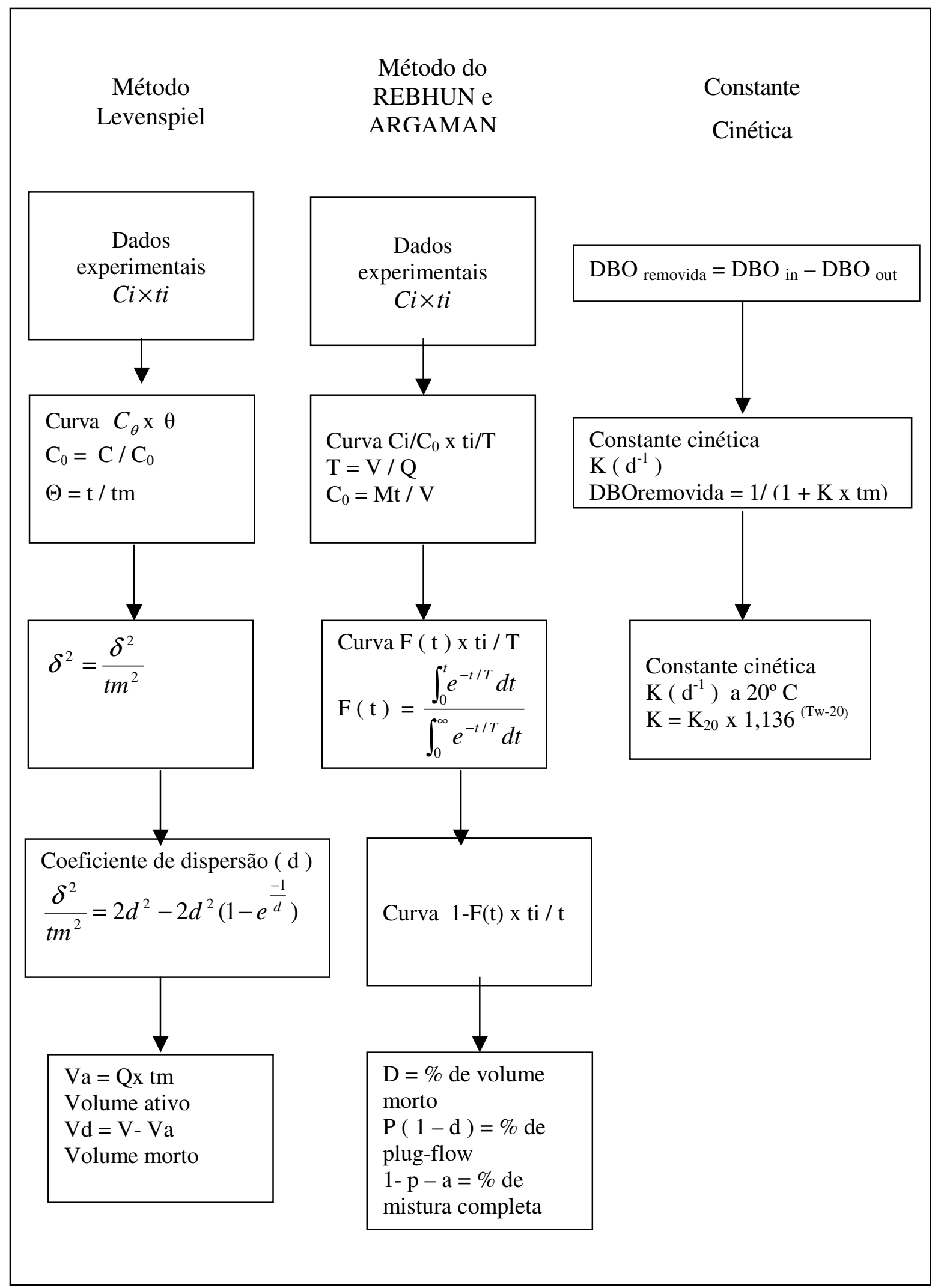

